\begin{tabular}{|l|l|}
\hline $\begin{array}{l}\text { 2. To: (Receiving Organization) } \\
\text { Distribution }\end{array}$ & $\begin{array}{l}\text { 3. From: (Originating Organization) } \\
\text { WRAP Engineering }\end{array}$ \\
\hline 5. Proj./Prog./Dept./Div.: & $\begin{array}{l}\text { 6. Design Authority/ Design Agent/Cog. } \\
\text { Engr.: }\end{array}$ \\
W-026/WMH & N/A \\
\hline
\end{tabular}

8. Originator Remarks:

This EDT is to release supporting documentation for the WRAP Facility to Engineering Files.
11. Receiver Remarks: 11A. Design Basel ine Document? [] Yes [X] No

4. Related EDT No.:

N/A

7. Purchase Order Ho.:

$N / A$

9. Equip./Component Ho.:

$\mathrm{N} / \mathrm{A}$

10. System/Bldg./Facil ity: 2336-W

12. Major Assm. Dwg. No.: N/A

13. Permit/Permit Application Ho.: $N / A$

14. Required Response Date: $N / A$

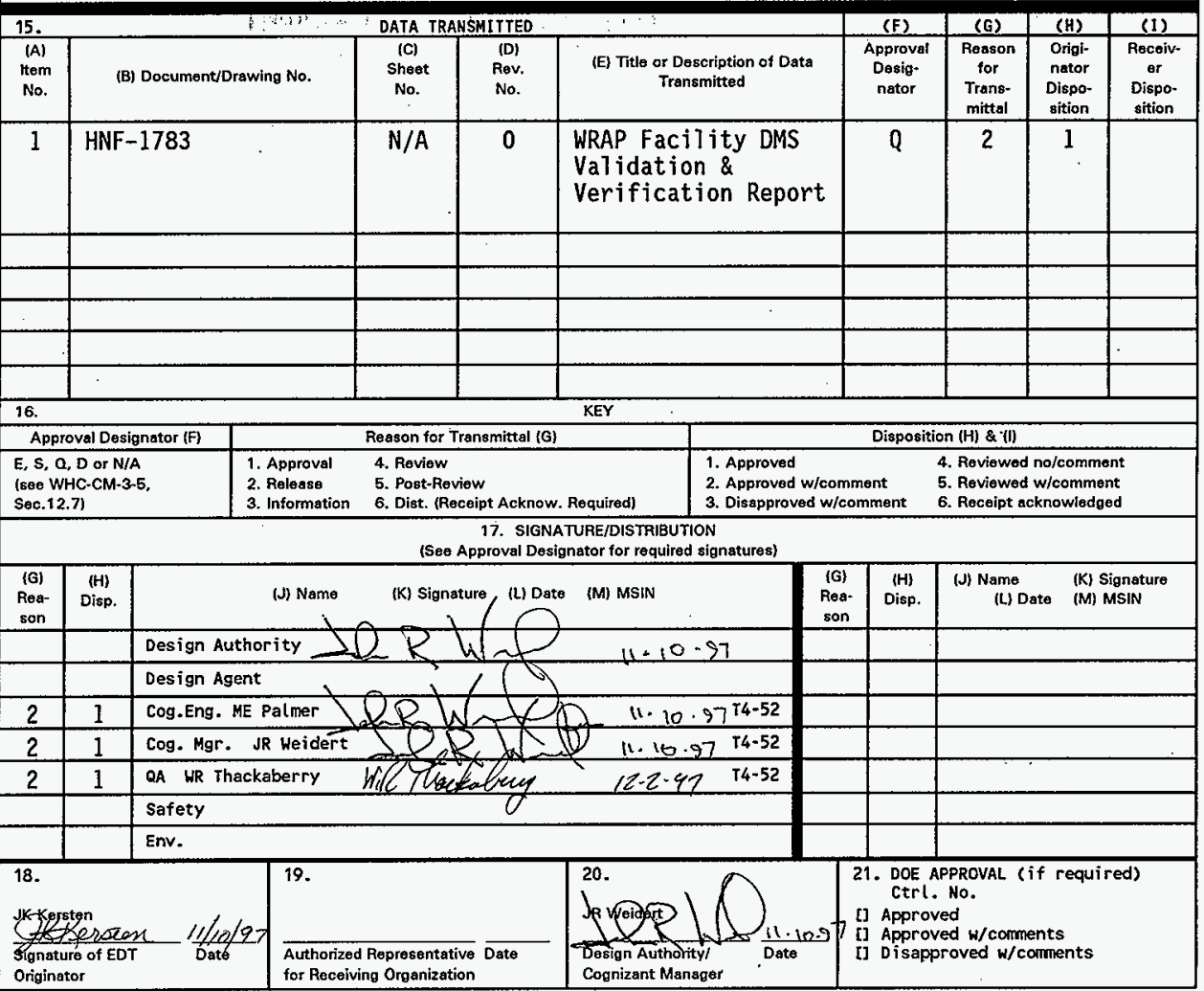


HNF-1783, Rev. 0

\title{
W-026, WASTE RECEIVING AND PROCESSING FACILITY DATA MANAGEMENT SYSTEM VALIDATION AND VERIFICATION REPORT
}

\author{
ME Paimer \\ Waste Management Federal Services of Hanford, Inc., Richland, WA 99352 \\ U.S. Department of Energy Contract DE-AC06-96RL13200
}

EDT/ECN: $\quad$ EDT-620621 UC: 506

Org Code: 32620

B\&R Code: EW3130020

Charge Code: A2EID

Total Pages: 2640265

सrose $12 / 5 / 67$

Key Words: WRAP, BDM, SDD, BWAS, V\&V, DMS, Software

Abstract: This V\&V Report includes analysis of two revisions of the DMS System Requirements Specification (SRS) and the Preliminary System Design Document (PSDD); the source code for the DSM Communication Module (DMSCOM) messages; the source code for selected DMS Screens, and the code for the BWAS Simulator.

*ORACLE is a registered trademark of Oracle Corporation, Redwood Shores, CA.

*SQL*PLUS is a registered trademark of Oracle Corporation, Redwood Shores, CA.

TRADEMARK DISCLAIMER. Reference herein to any specific commercial product, process, or service by trade name, trademark, manufacturer, or otherwise, does not necessarily constitute or imply its endorsement, recommendation, or favoring by the United States Goverment or any agency thereof or its contractors or subcontractors.

Printed in the United States of America. To obtain copies of this document, contact: Document Control Services, P.0. Box 950, Mailstop H6-08, Richland WA 99352, Phone (509) 372-2420; Fax (509) 376-4989.
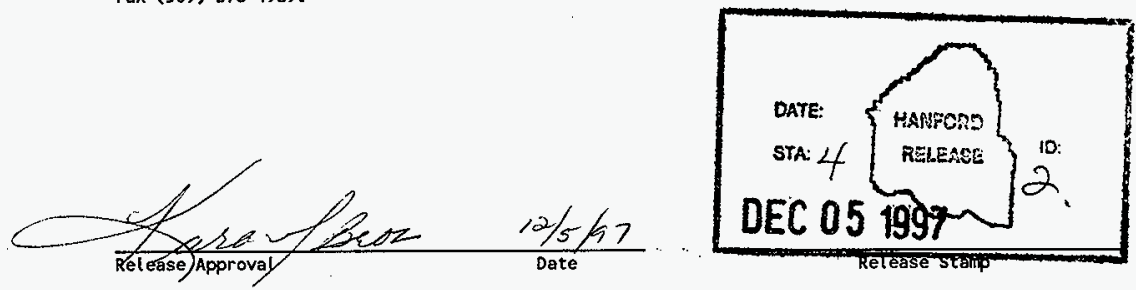

Approved for Public Release 


\subsection{INTRODUCTION}

1.1 Purpose

1.2 Scope

1.3 Analytic Approach

1.4 Discrepancy Tracking and Resolution

2.0 ASSESSMENT OF OVERALL QUALITY

2.1 System Requirements Specifications (SRS)

2.2 System Design Document (SDD)

2.3 DMS Communication Module

2.4 Screen Source Code

\subsection{RECOMMENDATIONS}

3.1 System Requirements Specification

3.2 System Design Document

3.3 DMS Communication Module

3.4 Screen Source Code

4.1 SYSTEM REQUIREMENTS SPECIFICATION (SRS) COMPARED TO SYSTEM DESIGN DOCUMENT (SDD)

$\begin{array}{lll}4.1 .2 & \text { Scope } & 10\end{array}$

$\begin{array}{ll}\text { 4.1.3 Description of Analysis Approach } & 10\end{array}$

4.1.4 Analytic Overview 11

4.1.4.1 General Observations 11

4.1.4.2 Discrepancy Synopsis and Resolution Matrices 12

4.2 SYSTEM DESIGN DOCUMENT (SDD) INTERNAL INTEGRITY

$\begin{array}{lll}4.2 .1 & \text { Purpose } & 68\end{array}$

$\begin{array}{lll}4.2 .2 & \text { Scope } & 68\end{array}$

4.2.3 Description of Analysis Approach $\quad 68$

4.2.4 Analytic Overview $\quad 69$

4.2.4.1 General Observations $\quad 69$

4.2.4.2 Discrepancy Synopsis and Resolution Matrices 71 


\subsection{DMS COMMUNICATIONS MODULE}

4.3.1 Purpose

4.3.2 Scope

4.3.3 Description of Analysis Approach

4.3.4 Analytic Overview

4.3.4.1 General Observations

4.3.4.2 Discrepancy Synopsis and Resolution Matrices

4.4 SCREEN SOURCE CODE REVIEW

4.4.2 Scope

4.4.3 Description of Analysis Approach

4.4.4 Analytic Overview

4.4.4.1 General Observations

4.4.4.2 Discrepancy Synopsis and Resolution Matrices

\subsection{BWAS SIMULATOR SOURCE CODE REVIEW}

4.5.1 Purpose

4.5.2 Scope

4.5.3 Description of Analysis Approach

4.5.4 Analytic Overview

4.5.4.1 General Observations

253

4.5.4.2 Discrepancy Synopsis and Resolution Matrices 


\section{EXECUTIVE SUMMARY}

\subsection{BACKGROUND}

BDM Federal, Inc. was tasked to conduct an independent Validation and Verification (V\&V) analysis of the DMS development. This V\&V effort includes review of the DMS documentation and the source code being prepared by the DMS developer.

The V\&V effort will continue through the various development phases of the DMS. The first release of the V\&V Report was provided with the findings through March 12, 1996. This overview provides updated findings through September 27, 1996.

\subsection{ANALYSIS CONDUCTED}

BDM Federal analysts used a series of matrices to:

- compare the requirements in the System Requirements Specification (SRS) to the specifications found in the System Design Document (SDD), to ensure the design supports the business functions,

- compare the discreet parts of the SDD with each other, to ensure that the design is consistent and cohesive,

- compare the source code of the DMS Communication Module with the specifications, to ensure that the resultant messages will support the design,

- compare the source code of selected screens to the specifications to ensure that resultant system screens will support the design,

- compare the source code of the BWAS simulator with the requirements to interface with DMS messages and data transfers relating to the BWAS operations. 


\subsection{DISCREPANCY TRACKING}

\subsection{Discrepancy Categories}

V\&V discrepancies have been categorized as follows:

\section{Category 1 Discrepancies}

These are discrepancies the analyst considered to have high potential for a major impact on the development. If these discrepancies are not corrected, the system will fail to perform as planned.

\section{Category 2 Discrepancies}

These are discrepancies the analyst considered to have moderate impact on the system. If these are not corrected, the system will continue to fulfill the major intent of the analytic area in question, but it may not act quite as envisioned when the requirement or specification was originally prepared.

\section{Catgegory 3 Discrepancies}

These are minor discrepancies of no immediate impact such as typos, inconsistent naming conventions, etc. These have been identified to be included in future new releases of affected documentation.

\subsection{Discrepancy Tracking}

All discrepancies were consolidated into "resolution matrices". These matrices group the discrepancies by analysis topic and discrepancy category. They include a column for resolution actions.

During module test procedure review sessions attended by WHC and the developer, those V\&V discrepancies which affected that particular module were also reviewed and resolution actions were decided. These resolution actions are included in the resolution matrices. Closure dates are entered as the actions are completed.

All V\&V analysis was conducted from a "frozen" set of SRS and SDD documents and with final source code. Some changes to the SDD were made during the V\&V, but these 
were not incorporated into the analysis. Instead, if they addressed V\&V discrepancies, they were subsequently noted in the resolution matrices as having resolved those discrepancies and the actions were closed. In addition, system testing proceeded to exercise the source code, and the test results were used to verify that much of the source code discrepancies had been resolved.

\subsection{SYNOPSIS OF FINDINGS}

4.1 101 requirements and sub-processes were compared to the SDD.

\section{Discrepancies Resolution Action}

Found

Completed
17

49

$\begin{array}{llll}\text { Category } 3 & 37 & 10 & 27\end{array}$

Closure Deferred Until Ph $2 / 3$ or Next SRS**

7

41

$\begin{array}{llll}\text { Category } 3 & 37 & 10 & 27\end{array}$

**Note: For deferred closures: corrective action has been already identified.

4.2 15 Modules and associated screens, plus DMSCOM and DMS Reports were reviewed in the SDD.

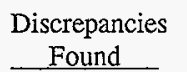

Category 1

Category 2

Category 3
Resolution Action Completed

161

122

102
Closure Deferred Until Ph 2/3 or Next SDD***

**Note: For deferred closures: corrective action has been already identified. 
4.3 Source code for all of the Communication Module (Phase 1) was compared to the SDD

Discrepancies

Found

Category 1

Category 2

Category 3
9

16

10
Resolution Action

Completed

9

16

10

4.4 Source code for 13 Screens was compared to the SDD

Discrepancies
Found

Category 1

Category 2

Category 3
30

35

16
Resolution Action

Completed $* *$

30

35

16

**Note: Testing indicates discrepancies are resolved. Meanwhile, the SDD is being updated to reflect Phase 1 "as-built" specifications. This update will incorporate the resolution actions of affected module screens.

\subsection{GENERAL ASSESSMENT}

1. Major requirements have all been incorporated into the design. Many discreet "subprocesses" within these requirements differ from the design in their low level details.

2. Discrepancies between the SRS and SDD often reflect the fact that the SRS has not been kept up to date as the design progressed. Consequently, the SDD tends to be more current, with later approved changes. This has eroded the SRS's value as a baseline definition of scope and functionality. A new release of the SRS subsequently addressed most of this problem. 
3. There are multiple discrepancies across the discreet design parts of the SDD. The general design and eight appendices supporting the detailed design tend to reflect differing authors and a mix of development methodologies. The lack of a single repository and consistent methodology makes it difficult to update one part of the design and ensure all other inter-related parts are also updated.

4. The source code also reflects some late design changes that have not migrated back to the SDD.

5. As the SDD cohesiveness and consistency have been affected, this has eroded the SDD's value as a baseline specification document. It has been updated to an "as built" status reflecting the latest design at the completion of the first release of the DMS software. It needs further updates as DMS development continues.

6. The source code itself tends to reflect sound programming practice. A mix of logic errors and "bugs" have been found, but not in amounts abnormal to this stage of development. These have been generally corrected quickly when identified as verified by the fact that the affected system features eventually passed functional and performance testing.

\subsection{RECOMMENDATIONS}

1. Place the SRS and SDD under strict configuration control and keep them current with ongoing decisions.

2. Continue to track V\&V discrepancies to closure.

3. Consider migrating the SDD into some electronic version that better supports interdependencies during iterative updates. Since ORACLE is the primary programming language, consideration should be given to using the ORACLE CASE product, or some other CASE tool technology. 


\subsection{INTRODUCTION}

\subsection{Purpose}

The Waste Receiving and Processing Facility (Module 1) (WRAP 1) requires Verification and Validation (V\&V), testing, and procedural support during development of the facility's Data Management System (DMS).

\subsection{Scope}

This V\&V Report includes analysis of two revisions of the DMS System Requirements Specification (SRS) and the Preliminary System Design Document (PSDD); the source code for the DMS Communication Module (DMSCOM) messages; the source code for selected DMS screens, and the code for the BWAS simulator.

This V\&V Report provides the V\&V analytic results for all phases of the DMS development as contained in the SRS and SDD. The initial release of the WRAP1 DMS V\&V Report contains the screen source code review for only screens and communication messages constructed during Phase 1 of the system development. This report has been periodically updated and reissued as the development progresses. At the end of each DMS development phase, a new version of the DMS V\&V Report shall incorporate all prior V\&V results in addition to findings from the latest phase.

\subsection{Analytic Approach}

The V\&V analysts used several matrices to map SRS requirements to the SDD, to map internal SDD design across the various SDD sections and appendices, and to map the DMSCOM and certain screen code against the SDD. Discrepancies and comments were recorded as applicable.

\section{System Requirements Document (SRS) Compared to System Design Document (SDD)}

For this analysis, the requirements in the SRS were mapped to the processes and their descriptions in the SDD Appendix F Process Model. Matrices were prepared which compared the SRS system message requirements to the SDD Communication Module (Appendix F, Section 3.18) design and the other SRS requirements with their associated processes. 


\section{System Design Document Integrity}

For this analysis, the internal appendices and design features described in the SDD were compared against each other to determine their consistency and the general integrity of the various design parts.

As an extension of the SDD analysis, the Journaling and Archiving design was compared to the "as-built" ORACLE code to determine if the triggers and functions in the code were implementing the design. This portion of the analysis did not lend itself to a matrix layout. The results are included in this $V \& V$ report in more traditional report format.

\section{DMS Communications Module Review}

For this analysis, the container tracking requirements were compared to the specifications for the Communications Module in Appendix F. Also, DMS Communication Module source code was compared to the SDD design to ensure that the design was being implemented.

\section{Screen Source Code Review}

For this analysis, the code for individual DMS screens was compared to the SDD design to ensure that the design was being implemented.

Discrepancies noted were cataloged based on the analyst's judgement of relative risk and impact on the DMS system. This was done to draw attention to corrective actions in a priority order with the first emphasis being on those discrepancies that may directly impact the Phase 1 implementation. Discrepancy categories and their recommended corrective actions are defined as follows.

\section{BWAS Simulator Review}

The source code for the BWAS Simulator was reviewed to ensure it will adequately imitate the transfer of data and messages between the BWAS system and DMS. 


\section{CATEGORY 1}

These discrepancies have the potential for causing severe development implementation problems. If they are not resolved, there is high risk that the implemented module will not function as required in the SRS or SDD. Examples of such discrepancies include:

- SRS requirements missing from Appendix F;

- Appendix F inputs or outputs different from those discussed in the SRS;

- Software code that will not perform as indicated in the SDD, etc.

\section{CATEGORY 2}

These discrepancies indicate minor differences between the SRS requirements and the SDD design, or apparent design mismatches across the SDD sections and chapters. The system can be implemented with these discrepancies and will fulfill the primary intent of the SRS and the SDD. However, the results may differ slightly from the original user vision underlying the SRS preparation or the design work in other parts of the SDD. Such differences may frequently reflect later insights noted during design which have not migrated back into the SRS or SDD. There may also be new functionality introduced in the design which constitutes an increase in scope and cost beyond what was envisioned when these documents were prepared. Examples of such discrepancies include:

- Appendix F processes which are described with minor differences from their SRS requirement descriptions;

- Screens described in Appendix A with different data than is described in the general specifications System Navigation text;

- Discrepancies between report layouts and specified data calls in the design, etc.

\section{CATEGORY 3}

These discrepancies reflect minor editorial updates to either the SRS or the SDD. Such discrepancies include typographical errors, changes in naming conventions (i.e., the same item has two different names), discrepancies between data flow diagrams (DFDs) and Appendices, etc. 


\subsection{Discrepancy Tracking and Resolution}

As the discrepancies were noted, they were entered on summary matrices which include a column for resolution. Discrepancies were discussed during bi-weekly review meetings and at test procedure review sessions. Resolutions were recorded as they occurred. These Resolution Matrices are provided as part of this report. category:

Actions and urgency for correction were determined based on the discrepancy

- Category 1 discrepancies received immediate attention and were resolved during test procedure review sessions. Corrective actions were taken as identified.

- Category 2 discrepancies were reviewed to verify that they were acceptable/unacceptable prior to implementation. Decisions were made to:

- amend the design;

- stop further development on unneeded processes; or

- continue with the development as designed and update the SRS and/or SDD.

- Category 3 discrepancies were addressed during final updates to the SRS and SDD.

\subsection{ASSESSMENT OF OVERALL QUALITY}

The following general assessments represent analytic conclusions incorporating a synopsis of trends and indicators noted during the detailed analysis. More specific findings are contained in the detailed analytic paragraphs that follow.

\subsection{System Requirements Specifications (SRS)}

\section{Strengths}

- The document contains the major informational sections required by WHC-CM-310, Software Development, which is the source document for IEEE development methodology guiding the DMS project. 
- The document contains all of the major functional requirements which the DMS system will support.

- The requirement statements are generaliy statements of work provided from the operator and WRAP1 processing perspective.

- Other unique requirements and constraints such as operating environment, performance expectations, and user interface expectations are included.

\section{Weaknesses}

- The document has not been kept current as the design phase has progressed; new requirement insights normal to the detailed analysis and decisions during design have not migrated back to the SRS. This has eroded the value of the SRS to define the DMS functional baseline and to control system scope.

- Security expectations are poorly defined, especially for signature password requirements.

- Administrative and procecural interactions are poorly defined, especially for system administration and database administration.

\subsection{System Design Document (SDD)}

\section{Strengths}

- All of the major design features are included as required by WHC-CM-3-10, Software Development.

- Both general and detailed design are specified.

- All of the major requirements have been addressed.

- The requirements are mapped into focused system modules. 


\section{Weaknesses}

- The design details are not always consistent across the discreet SDD design sections; a description or detail in one appendix may be used or described differently in another appendix.

- There is no standard methodology used across the entire design. The various sections reflect authorship by diverse persons at diverse times, and each seems to have adopted his/her own convention for defining that particular portion of the design. A central repository for definition, models, and modular interaction is missing, creating a high potential for inconsistency throughout the development.

- There are several inconsistencies between minor details of the SDD and the SRS. While there are few instances where a single inconsistency indicates a major system deviation, in aggregate, the number of inconsistencies indicates the design is not fully compatible with the SRS. The above comments regarding the SRS being out of date are a large factor in this problem.

- The design is lacking in clear specification for system administration tools, security enforcement, and general performance expectations (throughput, timeliness, hours of operations, batch-versus-real time operations, etc.) Again, some of this vagueness can probably be traced to a comparable vagueness in the SRS in some of these issues such as system administration and security requirements.

- There has been an apparent attempt to introduce into the SDD some of the functional requirement perspective normally reserved for the SRS. This is probably meant to compensate for the SRS becoming out of date.

- The system owner has maintained the SDD. This has caused the functional operator customer to have to assume responsibility for definition of the technical solutions expected from the developer. 


\subsection{DMS Communication Module}

\section{Strengths}

- The source code has a high degree of consistency with the specifications with regard to message definition.

- The source code is prepared following industry convention regarding modularity as a whole, use of generic called functions, field and table naming conventions, and error trapping.

\section{Weaknesses}

- The source code has some specific inconsistencies with the SDD. In aggregate, these would cause the system to perform differently than expected for some modules.

- There are some instances where modularity breaks down. Some of the code sections appeared to have been "cut and pasted" resulting in "code bloat". For example, the function ora pcsdms_clo is 1066 lines long and is expected to become larger as Phase 2 and Phase 3 functionality is implemented.

- Some logic errors and "bugs" have been noted in the code and have been brought to the attention of the developer.

\subsection{Screen Source Code}

\section{Strengths}

- The use of a 4 th Generation Language has led to consistent implementation of the design.

- There is a high degree of modularity with the screens. Common functions are implemented once, such as security checking.

- Well documented. Due to the declarative nature of a 4th Generation Ianguage it is easy to determine a display field's attributes-- enabled, navigable, updatable, datastore, etc. 


\section{Weaknesses}

- The source code has some specific inconsistencies with the SDD. In aggregate, these would cause the system to perform differently than expected for some of the screens.

- Some logic errors and "bugs" have been noted in the code and have been brought to the attention of the developer.

- Reliance on the declarative nature of a 4 th Generation Language and vagueness of the SDD has resulted in a lack of documentation regarding "as built" features.

- The "work arounds" implemented to get Oracle Forms to perform as required are not documented.

\subsection{RECOMMENDATIONS}

Each resolution matrix is preceded with a discussion of general errors and recommendations specific to the analytic results noted in that matrix. The following represent general recommendations which are provided to address the trends noted during the $\mathrm{V} \& \mathrm{~V}$ analysis.

\subsection{System Requirements Specification}

- Resolve all discrepancies noted during the V\&V Analysis and update the SRS accordingly.

- Place the SRS under configuration control and keep it up to date.

- Use the SRS to gauge the compliance of the system with the needs of the functional requirements.

- Form a customer/operator review group which can evaluate baseline requirements, compare these to both business rule and technical design change influences, and determine needed changes with priority, cost-benefit tradeoffs, and facility impacts. 


\subsection{System Design Document}

- Resolve all discrepancies noted during the V\&V Analysis and update the SDD accordingly.

- Transfer the SDD to the developer.

- Update the SDD to reflect "as-built" conditions, then keep it under configuration control.

- Establish a single methodology for the design and update all design sections to that standard - then keep the sections consistent (i.e., be able to trace the affects of any design change across all of the design's salient parts and make the appropriate changes).

\subsection{DMS Communication Module}

- Resolve all code errors.

- Update the source code to reflect the SDD after the SDD has the "as-builts" incorporated.

- Increase modularity and reduce redundant coded sections.

\subsection{Screen Source Code}

- Resolve all code errors.

- Update the source code to reflect the SDD after the SDD has the "as-builts" incorporated.

- Document the "work-arounds" implemented to get Oracle Forms to perform as required.

- Standardize the "work-arounds" to get Oracle Forms to perform as required. 


\subsection{SYSTEM REQUIREMENTS SPECIFICATION (SRS) COMPARED TO SYSTEM DESIGN DOCUMENT (SDD)}

\subsubsection{Purpose}

This analysis is to identify the level of consistency between the DMS functional requirements and the system design, and to report any inconsistencies noted.

\subsubsection{Scope}

This analysis focused on the requirements in the SRS as compared to the design description in the SDD. Appendix F of the SDD (Revision 2) was the primary focus of the SDD for comparison to the specifications located in that portion of the document. However, screen requirements and general miscellaneous requirements were compared to other SDD Sections as appropriate.

\subsubsection{Description of Analysis Approach}

For this analysis three types of matrices were prepared:

- One matrix type mapped SRS message requirements to the SDD Appendix F, citing the type of message, the Appendix F Unit Process intended to produce the message, and related comments. This matrix type was devised to address the fact that there is no direct SRS-to-module mapping for the messages required in the communication module. Instead, messages and other communication requirements are spread across all of the requirements as needed.

- One matrix type mapped SRS requirements with their associated processes, inputs, and outputs directly to the Appendix $F$ module which matches the intended functional support of the design. Comments are again provided as necessary.

- One matrix type compared the SRS to the SDD for general requirements which apply to the system as a whole (security, log-on, user interfaces, system administration, etc.). These requirements are not specific to a particular process or system module.

These detailed matrices are compiled in the DMS project files as working papers. They are in binders marked as "WRAP 1 DMS V\&V Analysis". They are available for 
review should questions arise regarding the source of the discrepancies and comments provided in this V\&V Report

Comments in all matrices are intended to point out discrepancies in the SRS-to-SDD mapping, or other insights which the analyst deemed necessary to bring to the system owner's attention. Where comments pertain to discrepancies, these were categorized to reflect their potential severity or impact on the design. (See the Introduction section of this V\&V Report for a definition of discrepancy categories.)

\subsubsection{Analytic Overview}

\subsubsection{General Observations}

In addition to the specific comments and discrepancies noted in the matrices, the following general comments are noted:

Category 2 concerns:

- There is no clear SRS requirement for status checking across the systems to be channeled through DMS; i.e., the Plant Control System (PCS) could be doing its own status checking. Because of design and cross-contractor complexities across the various WRAP systems, all such status checking is being channeled through DMS. While this approach will satisfy any PCS requirement to keep abreast of system statuses, it does add additional complication to the DMS communication module and associated message traffic load on the WRAP1 Local Area Network (WLAN).

- The requirements for system administration and maintenance are poorly defined. They tend to be simple statements that these functions will be performed. The responsibilities and the expected technical capabilities for these persons should be defined in more detail.

Category 3 concerns:

- SRS paragraph 3.2.3, Software Interfaces only requires updates to SWITS. Several of the SRS requirements and the Appendix F processes retrieve data from SWITS. 


\subsubsection{Discrepancy Synopsis and Resolution Matrices}

The following matrix contains a synopsis of the discrepancies which are described in the analytic matrices found in the DMS project files. This synopsis groups the discrepancies by category. It then provides resolution actions which were decided during the course of the V\&V analysis. Those actions which are closed are also noted.

The resolution matrix will be considered a tracking mechanism to monitor all discrepancies until they are closed. Consequently, it will be periodically updated to reflect closed actions. If requirements are changed during the DMS development, these changes will be noted in the resolution matrix as pending actions and will be tracked as with any other actions. 


\begin{tabular}{|c|c|c|c|c|}
\hline SRS REFERENCE & REQUIREMENT & DISCREPANCY & RATIONALE FOR CATEGORY & RESOLUTION \\
\hline \multicolumn{5}{|c|}{ CATEGORY 1 DISCREPANCIES } \\
\hline \multirow[t]{2}{*}{$\begin{array}{l}\text { 3.1.2.2.2 Drum or Box } \\
\text { Container NDA Results }\end{array}$} & $\begin{array}{l}\text { Signature Password for any } \\
\text { comments that have been } \\
\text { generated }\end{array}$ & $\begin{array}{l}\text { Appendix } F \text { specifications for } \\
\text { module } 3.1 .2 .2 \text {, Drum or Box } \\
\text { NDA, have no reference to } \\
\text { signature password entry or } \\
\text { validation for this process } \\
\text { although screen } 0202 \text { shows a } \\
\text { place for entry }\end{array}$ & $\begin{array}{l}\text { unclear how the signature password will } \\
\text { be applied to the module processing }\end{array}$ & $\begin{array}{l}\text { 1/30/96: Test Proc } \\
\text { Review Meet: SRS should } \\
\text { be updated regarding } \\
\text { signature passwords - note } \\
\text { signature password review } \\
\text { matrix in V\&V Report } \\
\text { Appendix B } \\
\text { Action Completed and } \\
\text { Discrepancy Item Closed: } \\
\text { 2/28/96 }\end{array}$ \\
\hline & $\begin{array}{l}\text { Update DMS database with user } \\
\text { comments after the Signature } \\
\text { Password is verified }\end{array}$ & $\begin{array}{l}\text { no indication of data base updates } \\
\text { for comments or signature } \\
\text { password - updates may be part of } \\
\text { Exit button? }\end{array}$ & $\begin{array}{l}\text { signature password specification unclear - } \\
\text { comments update does not seem to be } \\
\text { specified }\end{array}$ & $\begin{array}{l}\text { 1/30/96: Test Proc Review } \\
\text { Meet: SRS should be } \\
\text { updated to remove need for } \\
\text { signature password for this } \\
\text { process } \\
\text { Action Completed and } \\
\text { Discrepancy Item Closed: } \\
\text { 2/28/96 }\end{array}$ \\
\hline
\end{tabular}




\begin{tabular}{|c|c|c|c|c|}
\hline SRS REFERENCE & REQUIREMENT & DISCREPANCY & RATIONALE FOR CATEGORY & RESOLUTION \\
\hline $\begin{array}{l}\text { 3.1.2.3 NDA Verification } \\
\text { and Background } \\
\text { Containers }\end{array}$ & $\begin{array}{l}\text { QC data from assays archived } \\
\text { directly from SIE }\end{array}$ & $\begin{array}{l}\text { assumed to be simply another } \\
\text { update with an RESS message - } \\
\text { unique only because of drum type }\end{array}$ & $\begin{array}{l}\text { should verify - part of general archive } \\
\text { specification requirement which has not } \\
\text { been defined? }\end{array}$ & $\begin{array}{l}\text { Comments provided after } \\
\text { review of V\&V } \\
\text { discrepancies: need to } \\
\text { verify with BNFL if RESS } \\
\text { message will be sent - } \\
\text { *:* follow on information } \\
\text { provided by DMS system } \\
\text { owners: no requirement } \\
\text { for DMS to store results } \\
\text { data for background and } \\
\text { verification containers - } \\
\text { Discrepancy Item Closed } \\
\text { as of } 4 / 1 / 96\end{array}$ \\
\hline $\begin{array}{l}\text { 3.1.3.1.1 LLW Entry } \\
\text { Glovebox }\end{array}$ & $\begin{array}{l}\text { input: "Drum Contamination } \\
\text { Status" message from the PCS }\end{array}$ & $\begin{array}{l}\text { no such message specified - } \\
\text { Process } 3.1 .8 \text { (Message Handling) } \\
\text { UP60 specifies such a message, } \\
\text { but no indication of how it relates } \\
\text { to this process }\end{array}$ & $\begin{array}{l}\text { sets CONEXT_CONTAM } \\
\text { FLAG - no usage of this data element by } \\
\text { process }\end{array}$ & $\begin{array}{l}\text { 1/30/96: Test Proc Review } \\
\text { Meet: database update } \\
\text { occurs in "background" by } \\
\text { DMSCOM - not apparent to } \\
\text { LLW process - SRS should } \\
\text { be updated to restate } \\
\text { requirement } \\
\text { Action Completed and } \\
\text { Discrepancy Item Closed: } \\
\text { 2/28/96 }\end{array}$ \\
\hline
\end{tabular}




\begin{tabular}{|c|c|c|c|c|}
\hline SRS REFERENCE & REQUIREMENT & DISCREPANCY & RATIONALE FOR CATEGORY & RESOLUTION \\
\hline & $\begin{array}{l}\text { process: Update the overpack } \\
\text { drum contamination status field } \\
\text { (not "Processing Status" field) } \\
\text { for the drum currently at the } \\
\text { LLW drum entry port }\end{array}$ & $\begin{array}{l}\text { no drum status field on this screen } \\
\text { - no update to the field specified } \\
\text { in this UP - UP3 displays a } \\
\text { DMSCOM default status for the } \\
\text { Transfer Drum, and permits user } \\
\text { modification related to Non- } \\
\text { Compliant packets only }\end{array}$ & $\begin{array}{l}\text { may not be able to retrieve or enter } \\
\text { needed data }\end{array}$ & $\begin{array}{l}\text { 1/30/96: Test Proc Review } \\
\text { Meet: SRS should be } \\
\text { updated to specify action by } \\
\text { DMSCOM } \\
\text { Action Completed and } \\
\text { Discrepancy Item Closed: } \\
\text { 2/28/96 }\end{array}$ \\
\hline \multirow[t]{2}{*}{$\begin{array}{l}\text { 3.1.4.3 Chain of } \\
\text { Custody/Sample Analysis } \\
\text { Request Form }\end{array}$} & $\begin{array}{l}\text { Request/generate hard copy of } \\
\text { "Chain of Custody/Sample } \\
\text { Analysis Request" form when } \\
\text { ready to send samples to the } \\
\text { laboratory }\end{array}$ & \multirow[t]{2}{*}{$\begin{array}{l}\text { no such form specified for display } \\
\text { or printing }\end{array}$} & \multirow[t]{2}{*}{ requirement not being fulfilled } & \multirow[t]{2}{*}{$\begin{array}{l}\text { DMSS0501, 504, } 506,507 \\
\text { and reports to be addressed } \\
\text { in Phase } 2\end{array}$} \\
\hline & $\begin{array}{l}\text { Generate the "Sample Analysis } \\
\text { Request" form }\end{array}$ & & & \\
\hline
\end{tabular}




\begin{tabular}{|c|c|c|c|c|}
\hline SRS REFERENCE & REQUIREMENT & DISCREPANCY & RATIONALE FOR CATEGORY & RESOLUTION \\
\hline $\begin{array}{l}\text { 3.1.4.4 Waste } \\
\text { Designation }\end{array}$ & input user Signature Password & $\begin{array}{l}\text { no specification for } \\
\text { signature/password if user adding } \\
\text { a sample }\end{array}$ & $\begin{array}{l}\text { may be missing a necessary security } \\
\text { check before action taken }\end{array}$ & $\begin{array}{l}\text { 1/30/96: Test Proc Review } \\
\text { Meet: SRS should be } \\
\text { updated - note signature } \\
\text { password review matrix in } \\
\text { V\&V Report Appendix B } \\
\text { Action Completed and } \\
\text { Discrepancy Item Closed: } \\
\text { 2/28/96 }\end{array}$ \\
\hline $\begin{array}{l}\text { 3.1.5.2.2 Certification } \\
\text { Data to SWITS }\end{array}$ & $\begin{array}{l}\text { A request by the user to transmit } \\
\text { certification data and the location } \\
\text { update information on the } \\
\text { pending shipment shown on the } \\
\text { "Loading Dock Container } \\
\text { Shipping" screen to SWITS. } \\
\text { This request is performed from } \\
\text { the "Loading Dock Container } \\
\text { Shipping" screen. }\end{array}$ & $\begin{array}{l}\text { UP11: DMS to transmit } \\
\text { applicable SWITS data to SWITS } \\
\text { for all drums sent to the } \\
\text { Processing Area in WRAP } \\
\text { UP12: DMS to transmit all } \\
\text { applicable SWITS data to SWTS } \\
\text { for all drums received by WRAP } \\
\text { these UPs specify selection of In } \\
\text { Transit button - updates SWITS } \\
\text { tables - no DMSCOM message is } \\
\text { found which sends this data }\end{array}$ & SWITS update is not specified & $\begin{array}{l}\text { Comments provided after } \\
\text { review of V\&V } \\
\text { discrepancies: DMS } \\
\text { directly updates the SWITS } \\
\text { data base } \\
\text { Discrepancy Item Closed }\end{array}$ \\
\hline
\end{tabular}




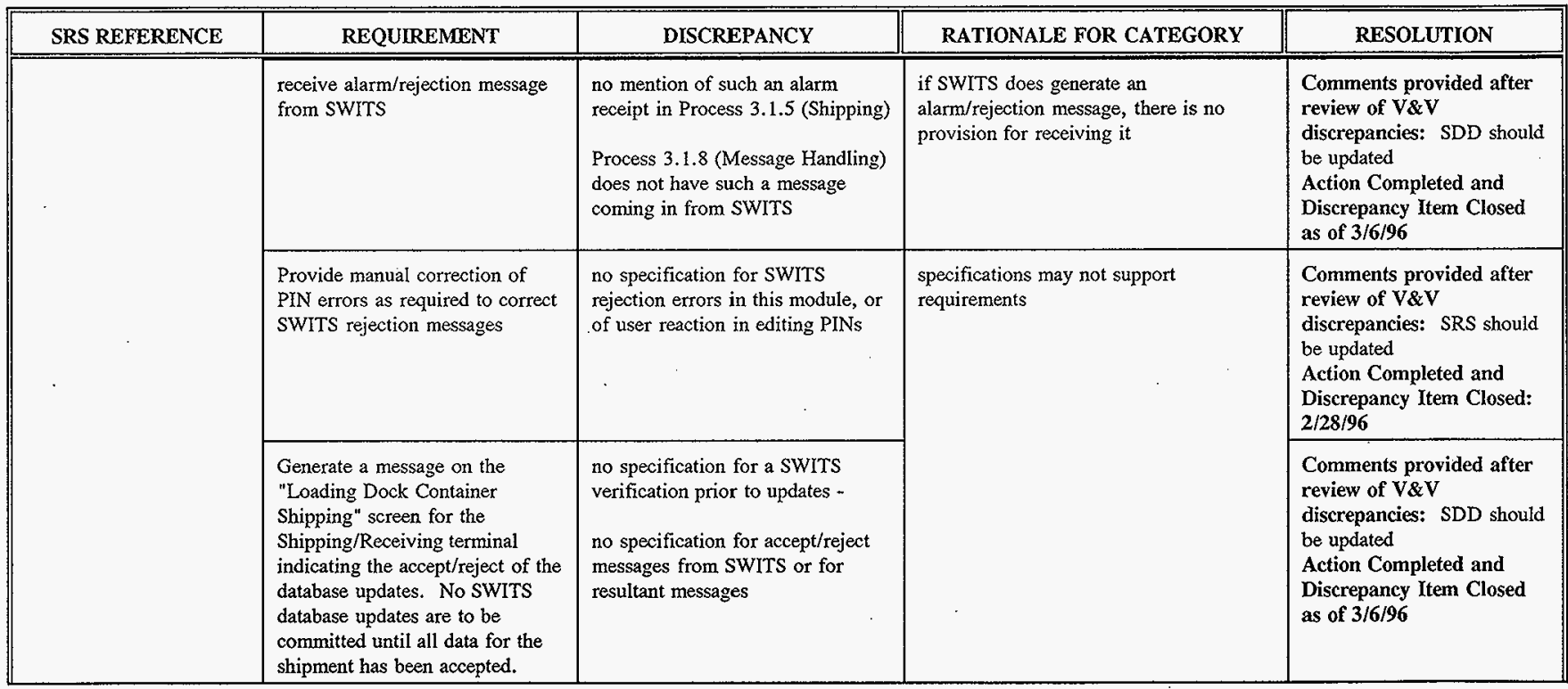




\begin{tabular}{|c|c|c|c|c|}
\hline SRS REFERENCE & REQUIREMENT & DISCREPANCY & RATIONALE FOR CATEGORY & RESOLUTION \\
\hline \multirow[t]{2}{*}{$\begin{array}{l}\text { 3.1.7.3 TRU Glovebox } \\
\text { Fissile Material Inventory } \\
\text { Check } \\
\text { 3.1.7.4 TRU RWM } \\
\text { Glovebox Fissile Material } \\
\text { Inventory Check }\end{array}$} & $\begin{array}{l}\text { User request to reset the } \\
\text { TRU/TRU RWM process } \\
\text { glovebox fissile material } \\
\text { inventory to an assayed/surveyed } \\
\text { value. This will normally be } \\
\text { performed each time the } \\
\text { glovebox is empty. }\end{array}$ & no specification for user reset & \multirow[t]{2}{*}{$\begin{array}{l}\text { may be missing needed processing to } \\
\text { fulfill requirement }\end{array}$} & $\begin{array}{l}\text { Comments provided after } \\
\text { review of V\&V } \\
\text { discrepancies: Proc } \\
3.1 .7 / U P 1 \text { updated to } \\
\text { provide this function ( } 1101 \\
\text { screen) } \\
\text { Action Completed and } \\
\text { Discrepancy Item Closed } \\
\text { as of } 3 / 6 / 96\end{array}$ \\
\hline & $\begin{array}{l}\text { When the SIE transmits a Pu- } 239 \\
\text { FGE value to the DMS for a } \\
\text { drum PIN that matches a drum } \\
\text { PIN on the TRU/TRU RWM } \\
\text { GIovebox Drum List, the DMS } \\
\text { will subtract the drum fissile } \\
\text { material inventory from the } \\
\text { TRU/TRU RWM glovebox } \\
\text { running total, remove the drum } \\
\text { PIN from the TRU/TRU RWM } \\
\text { Glovebox Drum List, and add the } \\
\text { drum PIN to the Facility } \\
\text { inventory. }\end{array}$ & no specification for this processing & & $\begin{array}{l}\text { Comments provided after } \\
\text { review of V\&V } \\
\text { discrepancies: SRS needs } \\
\text { update to specify action } \\
\text { taken when drum is at the } \\
\text { discharge conveyor rather } \\
\text { than when RESS message } \\
\text { received. } \\
\text { Action Completed and } \\
\text { Discrepancy Item Closed } \\
\text { as of } 3 / 6 / 96\end{array}$ \\
\hline
\end{tabular}




\begin{tabular}{|c|c|c|c|c|}
\hline SRS REFERENCE & REQUIREMENT & DISCREPANCY & RATIONALE FOR CATEGORY & RESOLUTION \\
\hline & $\begin{array}{l}\text { Reset TRU/TRU RWM glovebox } \\
\text { fissile material inventory to } \\
\text { assayed/surveyed value }\end{array}$ & no specification for this processing & & $\begin{array}{l}\text { Comments provided after } \\
\text { review of V\&V } \\
\text { discrepancies: } 3.1 .7 / \text { UP1 } \\
\text { has been updated to provide } \\
\text { this function (101 screen) } \\
\text { Action Completed and } \\
\text { Discrepancy Item Closed } \\
\text { as of } 3 / 6 / 96\end{array}$ \\
\hline & $\begin{array}{l}\text { Send a fissile material level } \\
\text { message to the PCS with the new } \\
\text { TRU/TRU RWM glovebox fissile } \\
\text { material inventory and an alarm } \\
\text { if the glovebox inventory exceeds } \\
90 \% \text { of the limit. }\end{array}$ & $\begin{array}{l}\text { UP42 of Process } 3.1 .8 \text { (Message } \\
\text { Handling) has an FML (Phase } 3 \\
\text { message) generated upon receipt } \\
\text { of a PCS CL - it only indicates } \\
\text { " } \mathrm{Y} \text { " or "N" whether an alarm is } \\
\text { present - neither } 3.1 .7 \text { nor the } \\
\text { TRU processes specify calculation } \\
\text { to determine if a } 90 \% \text { level has } \\
\text { been reached }\end{array}$ & & $\begin{array}{l}\text { Comments provided after } \\
\text { review of V\&V } \\
\text { discrepancies: SRS should } \\
\text { be revised to delete } 90 \% \\
\text { calculation - the FML } \\
\text { message }(3.1 .8 / U P 42) \text { has } \\
\text { inventory value in field } 4 \\
\text { Action Completed and } \\
\text { Discrepancy Item Closed } \\
\text { as of } 3 / 6 / 96\end{array}$ \\
\hline $\begin{array}{l}\text { 3.1.9 User Review/ } \\
\text { Modification of WRAP } 1 \\
\text { Waste Processing Data }\end{array}$ & $\begin{array}{l}\text { update the database and log the } \\
\text { changes with the user ID } \\
\text { (signature password) }\end{array}$ & $\begin{array}{l}\text { Appendix A screens for data } \\
\text { review do not include signature } \\
\text { passwords }\end{array}$ & $\begin{array}{l}\text { may be missing an access safeguard for } \\
\text { lower level data }\end{array}$ & $\begin{array}{l}\text { 1/30/96: Test Proc Review } \\
\text { Meet: SRS should be } \\
\text { updated to delete signature } \\
\text { password requirement } \\
\text { Action Completed and } \\
\text { Discrepancy Item Closed: } \\
\text { 2/28/96 }\end{array}$ \\
\hline
\end{tabular}




\begin{tabular}{|c|c|c|c|c|}
\hline SRS REFERENCE & REQUIREMENT & DISCREPANCY & RATIONALE FOR CATEGORY & RESOLUTION \\
\hline $\begin{array}{l}\text { 3.1.10.4 Ad Hoc } \\
\text { Reporting }\end{array}$ & $\begin{array}{l}\text { Select the "Ad Hoc Reporting" } \\
\text { screen } \\
\text { Input the structure query } \\
\text { language (SQL) commands and } \\
\text { procedural logic necessary to } \\
\text { retrieve the data needed. } \\
\text { If desired, invoke the print } \\
\text { function. } \\
\text { Invoke Oracle's SQL*Plus } \\
\text { program. } \\
\text { Using the SQL commands and } \\
\text { procedural logic input by the } \\
\text { user, search the database in a } \\
\text { read-only mode and formate the } \\
\text { requested data for the terminal } \\
\text { screen. } \\
\text { If the print function is selected, } \\
\text { format the selected data for the } \\
\text { selected printer. }\end{array}$ & $\begin{array}{l}\text { No reference to ad hoc reporting } \\
\text { in either general or specific design } \\
\text { specifications. The Main Menu } \\
\text { does include a Reports selection, } \\
\text { however, it is specified as "TBD". } \\
\text { There is no indication that it may } \\
\text { include an Ad Hoc reporting } \\
\text { capability. } \\
\text { All requirements for Ad Hoc } \\
\text { reporting imply that the user will } \\
\text { need to be comfortable with SQL } \\
\text { to structure custom ad hoc } \\
\text { reports. This would require extra } \\
\text { training for DMS users or } \\
\text { dependence on developer } \\
\text { programming staff in order to } \\
\text { retrieve such reports. }\end{array}$ & $\begin{array}{l}\text { specifications do not address how this } \\
\text { capability will be provided - even if SQL } \\
\text { dependent, access to data tables and SQL } \\
\text { query capability need specification }\end{array}$ & $\begin{array}{l}\text { Reporting requirements to } \\
\text { be addressed in Phase } 2 \text {. } \\
\text { DMS is designed so that } \\
\text { Operations personnel should } \\
\text { never require ad hoc } \\
\text { reporting. Most ad hoc } \\
\text { reporting use will be by } \\
\text { Generators (waste } \\
\text { "owners"), SWO, or facility } \\
\text { management. SWITS users } \\
\text { are already familiar with ad } \\
\text { hoc reporting. }\end{array}$ \\
\hline
\end{tabular}




\begin{tabular}{|c|c|c|c|c|}
\hline SRS REFERENCE & REQUIREMENT & DISCREPANCY & RATIONALE FOR CATEGORY & RESOLUTION \\
\hline $\begin{array}{l}\text { 3.1.11.1 SWITS } \\
\text { Compatible Table } \\
\text { Maintenance }\end{array}$ & $\begin{array}{l}\text { system/database administrators } \\
\text { able to download updated SWITS } \\
\text { tables }\end{array}$ & $\begin{array}{l}\text { no apparent system administration } \\
\text { functions which permit the } \\
\text { download of these tables as } \\
\text { required by the system } \\
\text { administrator - SDD does not } \\
\text { indicate a design to support the } \\
\text { system administrator rights and } \\
\text { functions for this download }\end{array}$ & $\begin{array}{l}\text { may not be able to accomplish this "on- } \\
\text { call" as required }\end{array}$ & $\begin{array}{l}\text { 1/18/96: Test Proc Review } \\
\text { Meet: no resolution } \\
\text { during Phase } 1 \text { - the tools } \\
\text { for this function have yet to } \\
\text { be determined - this is } \\
\text { pending definition of the } \\
\text { procedures associated with } \\
\text { the system administration } \\
\text { function, which then impact } \\
\text { the SA tool design }\end{array}$ \\
\hline $\begin{array}{l}\text { 3.1.12 Error Detection } \\
\text { and Recovery }\end{array}$ & $\begin{array}{l}\text { provide diagnostic software for } \\
\text { DMS and the status of the } \\
\text { communication interfaces - to be } \\
\text { defined during design }\end{array}$ & $\begin{array}{l}\text { specifications not part of the SDD } \\
\text { - still unclear how this } \\
\text { requirement will be fulfilled }\end{array}$ & $\begin{array}{l}\text { implementation of Phase } 1 \text { without this } \\
\text { feature will preclude recovery capability. }\end{array}$ & $\begin{array}{l}\text { 1/18/96: Test Proc Review } \\
\text { Meet: no resolution } \\
\text { during Phase } 1 \text { - Phase } 2 \text { is } \\
\text { supposed to define the } \\
\text { interaction with the journal - } \\
\text { whether this is a SA duty or } \\
\text { a programmer/developer } \\
\text { duty is not defined }\end{array}$ \\
\hline
\end{tabular}




\begin{tabular}{|c|c|c|c|c|}
\hline SRS REFERENCE & REQUUREMENT & DISCREPANCY & RATIONALE FOR CATEGORY & RESOLUTION \\
\hline 3.5.4 Maintainability & $\begin{array}{l}\text { global data changes provided } \\
\text { under controlled conditions by } \\
\text { authorized users - procedures, } \\
\text { screens, methodology to be } \\
\text { determined during design }\end{array}$ & $\begin{array}{l}\text { global update capability is an } \\
\text { implied capability of the data base } \\
\text { administrator, but tools, } \\
\text { techniques, procedures not } \\
\text { mentioned in SDD }\end{array}$ & $\begin{array}{l}\text { may not be able to accomplish global } \\
\text { updates except for lookup tables }\end{array}$ & $\begin{array}{l}\text { 1/18/96: Test Proc Review } \\
\text { Meet: global updates across } \\
\text { the data base will be handled } \\
\text { as enhancements/system } \\
\text { changes via SCR - SRS to } \\
\text { be updated to reflect this } \\
\text { approach } \\
\text { Action Completed and } \\
\text { Discrepancy Item Closed: } \\
2 / 28 / 96\end{array}$ \\
\hline 3.6.1 Database & $\begin{array}{l}\text { establish an historical database } \\
\text { for drums shipped from the } \\
\text { facility }\end{array}$ & $\begin{array}{l}\text { SDD has no specific mention of } \\
\text { any historical data retention or the } \\
\text { specifications for archiving }\end{array}$ & $\begin{array}{l}\text { may not be retaining the needed data for } \\
\text { the needed duration }\end{array}$ & $\begin{array}{l}\text { 1/18/96: Test Proc Review } \\
\text { Meet: no resolution } \\
\text { during Phase } 1 \text { - SDD } \\
\text { needs to be revised before } \\
\text { Phase } 2 \text { to address necessary } \\
\text { specifications }\end{array}$ \\
\hline $\begin{array}{l}\text { 3.6.5.1 General } \\
\text { (scheduling) }\end{array}$ & $\begin{array}{l}\text { Data will be retained on the } \\
\text { system to support year-end } \\
\text { report/processing ( } 15 \text { month } \\
\text { retention). The generation of } \\
\text { these reports will not impact } \\
\text { routine operations. }\end{array}$ & none & no specific "year end" reports specified & $\begin{array}{l}\text { Specific report formats to be } \\
\text { defined during operations. } \\
\text { Closed: } 4 / 10 / 96 \text { (Weidert). }\end{array}$ \\
\hline
\end{tabular}




\begin{tabular}{|c|c|c|c|c|}
\hline SRS REFERENCE & REQUREMENT & DISCREPANCY & RATIONALE FOR CATEGORY & RESOLUTION \\
\hline \multicolumn{5}{|c|}{ CATEGORY 2 DISCREPANCIES } \\
\hline none & none & $\begin{array}{l}\text { para 5.2.1 - WRAP 1 DMS } \\
\text { System Screen - WRAP } 1 \text { DMS } \\
\text { User Menu shows the following } \\
\text { selections not present as needed } \\
\text { Main Menu selections in the SRS: } \\
\text { Process (Glovebox) Operations, } \\
\text { Table Maintenance, Sample } \\
\text { Management, Shipping, System } \\
\text { Administration, Reports, Pick } \\
\text { List, Activity Comment. } \\
\text { Appendix A reflects these in the } \\
\text { screen design except for Activity } \\
\text { Comments }\end{array}$ & $\begin{array}{l}\text { need to validate SRS against SDD design } \\
\text { and ensure the selections are intended for } \\
\text { Main Menu selection }\end{array}$ & $\begin{array}{l}\text { 1/30/96: Test Proc Review } \\
\text { Meet: Appendix A is } \\
\text { correct - SRS should be } \\
\text { updated } \\
\text { Activity Comments is a } \\
\text { Phase } 2 \text { development } \\
\text { Comments provided after } \\
\text { review of V\&V } \\
\text { discrepancies: decision that } \\
\text { screen hierarchy is not } \\
\text { appropriate to SRS } \\
\text { Discrepancy Item Closed }\end{array}$ \\
\hline $\begin{array}{l}\text { 1.2 SCOPE } \\
\text { development has general } \\
\text { goals }\end{array}$ & $\begin{array}{l}\text { To provide other software } \\
\text { products to enhance the user's } \\
\text { need for analysis and display of } \\
\text { information (e.g., graphics and } \\
\text { report writer capabilities). }\end{array}$ & $\begin{array}{l}\text { no specific mention of any graphic } \\
\text { tools for users - reports only } \\
\text { generated by system (i.e., no user } \\
\text { report generator for custom } \\
\text { reports) - however, } \\
\text { implementation on a PC allows for } \\
\text { possibility of any number of PC- } \\
\text { based graphics and report tools }\end{array}$ & $\begin{array}{l}\text { SDD should provide for inclusion of this } \\
\text { requirement to support user output } \\
\text { formats }\end{array}$ & $\begin{array}{l}\text { To be addressed in Phase } 2 \text {, } \\
\text { at the earliest. }\end{array}$ \\
\hline
\end{tabular}




\begin{tabular}{|c|c|c|c|c|}
\hline SRS REFERENCE & REQUIREMENT & DISCREPANCY & RATIONALE FOR CATEGORY & RESOLUTION \\
\hline $\begin{array}{l}\text { Paragraph } 2.4 \text { GENERAL } \\
\text { CONSTRAINTS }\end{array}$ & $\begin{array}{l}\text { Security. Users shall be } \\
\text { restricted to specific applications } \\
\text { for which they are authorized. } \\
\text { These applications will be } \\
\text { identified during system design. }\end{array}$ & $\begin{array}{l}\text { SDD para } 4.3 .1 \text { : defines user } \\
\text { role groups and rights of each for } \\
\text { data and system access }\end{array}$ & $\begin{array}{l}\text { role of System Administrator includes } \\
\text { access to program level code - seems } \\
\text { broader definition than System } \\
\text { Administrator role discussed elsewhere }\end{array}$ & $\begin{array}{l}\text { 1/30/96: Test Proc Review } \\
\text { Meet: SRS should be } \\
\text { updated - security/roles to } \\
\text { be further defined during } \\
\text { Phase } 2\end{array}$ \\
\hline $\begin{array}{l}\text { 3.0 SPECIFIC } \\
\text { REQUIREMENTS }\end{array}$ & $\begin{array}{l}\text { Any requirements that are not } \\
\text { completely defined or appear as } \\
\text { new requirements during the } \\
\text { design phase will be added to the } \\
\text { DMS SRS via engineering } \\
\text { change to this document. }\end{array}$ & $\begin{array}{l}\text { multiple "redlining" and updates } \\
\text { to SDD very little update work } \\
\text { done to the SRS }\end{array}$ & $\begin{array}{l}\text { "baseline" definition valued of SRS has } \\
\text { been eroded }\end{array}$ & $\begin{array}{l}\text { SRS Revision } 1 \text { is a } \\
\text { complete reissue of SRS, } \\
\text { incorporating design changes } \\
\text { to date, discrepancies. } \\
\text { Closed: } 4 / 10 / 96 \text {. }\end{array}$ \\
\hline $\begin{array}{l}\text { Paragraph } 3.1 \\
\text { FUNCTIONAL } \\
\text { REQUIREMENTS }\end{array}$ & $\begin{array}{l}\text { Validate the User Password to } \\
\text { startup the DMS system. }\end{array}$ & $\begin{array}{l}\text { no reference in SDD regarding } \\
\text { "system startup" rights - perhaps a } \\
\text { de facto right by virtue of having } \\
\text { password? }\end{array}$ & $\begin{array}{l}\text { verify - is "DMS system startup" a } \\
\text { general term for accessing the DMS or is } \\
\text { it a special privilege tied to system } \\
\text { operation rights? }\end{array}$ & $\begin{array}{l}\text { 1/30/96: Test Proc Review } \\
\text { Meet: SRS should be } \\
\text { updated to change "startup" } \\
\text { to "logon" } \\
\text { Action Completed and } \\
\text { Discrepancy Item Closed } \\
\text { as of } 3 / 6 / 96\end{array}$ \\
\hline
\end{tabular}




\begin{tabular}{|c|c|c|c|c|}
\hline SRS REFERENCE & REQUIREMENT & DISCREPANCY & RATIONALE FOR CATEGORY & RESOLUTION \\
\hline $\begin{array}{l}\text { Signature Password SRS } \\
\text { requirements } \\
\text { 3.1.1.2.4 Retrieve Drum } \\
\text { or Box Container Data } \\
\text { from SWITS } \\
\text { 3.1.2.2.2 Dnum or Box } \\
\text { Container NDA Results } \\
\text { 3.1.3.1.8 LLW Glovebox } \\
\text { Product Drum Content } \\
\text { Inventory Update } \\
\text { 3.1.3.2.1 LLW RWM } \\
\text { Separate Compliant from } \\
\text { Non-compliant } \\
\text { 3.1.3.2.3 LLW Glovebox } \\
\text { Non-Compliant Item } \\
\text { Screening } \\
\text { 3.1.4.1 Obtain Waste } \\
\text { Sample and Initiate Chain } \\
\text { of Custody }\end{array}$ & validate signature password & $\begin{array}{l}\text { in general, these requirements } \\
\text { indicate a need to validate } \\
\text { signature passwords for their } \\
\text { associated work - Appendix } F \\
\text { tends to require entry of signature } \\
\text { passwords, but only rarely } \\
\text { mentions validation in the } \\
\text { specifications - this may be an } \\
\text { included part of the pseudo-code } \\
\text { semantics }\end{array}$ & $\begin{array}{l}\text { needs to be verified that simple entry of } \\
\text { signature password is or is not sufficient }\end{array}$ & $\begin{array}{l}\text { 1/30/96: Test Proc Review } \\
\text { meet: SDD needs a } \\
\text { statement in general design } \\
\text { constraints: unless } \\
\text { otherwise specified, all } \\
\text { commits/updates to the data } \\
\text { base require signature } \\
\text { password - inclusion of } \\
\text { signature password } \\
\text { requirement implies } \\
\text { validation check across } \\
\text { applicable security tables to } \\
\text { validate update authorities - } \\
\text { note signature password } \\
\text { review matrix in V\&V } \\
\text { Report Appendix B } \\
\text { regarding need to finalize } \\
\text { signature password } \\
\text { requirement for particular } \\
\text { processes } \\
\text { Comments provided after } \\
\text { review of V\&V } \\
\text { discrepancies under } \\
\text { general review - } \\
\text { requirements to be added to } \\
\text { front of Appendix } F\end{array}$ \\
\hline
\end{tabular}




\begin{tabular}{|c|c|c|c|c|}
\hline SRS REFERENCE & REQUIREMENT & DISCREPANCY & RATIONALE FOR CATEGORY & RESOLUTION \\
\hline \multirow[t]{2}{*}{$\begin{array}{l}\text { 3.1.1.2.1 Logging } \\
\text { Received Drum or Box } \\
\text { Containers }\end{array}$} & $\begin{array}{l}\text { receive PINs as block input from } \\
\text { PCS or manual input }\end{array}$ & $\begin{array}{l}\text { CLW in Unit Process } 39 \text { of } \\
\text { Process } 3.1 .8 \text { (Message Handling) } \\
\text { does not have date/time stamp }\end{array}$ & $\begin{array}{l}\text { date/time stamp is stated as a } \\
\text { requirement in SRS } 3.1 .8 \text { for all location } \\
\text { record updates - this design will not } \\
\text { provide it for this message }\end{array}$ & $\begin{array}{l}\text { 1/4/96: Test Proc Review } \\
\text { Meet: AS/RS pertains to } \\
\text { location changes only - } \\
\text { location updates not noted in } \\
\text { all SRS process descriptions: } \\
\text { deferred to table } 1 \text { of } \\
\text { process } 3.1 .8 \text { where the } \\
\text { generic location discussion } \\
\text { is considered to address this } \\
\text { discrepancy } \\
\text { Discrepancy Item Closed }\end{array}$ \\
\hline & $\begin{array}{l}\text { Allow user modification of the } \\
\text { PINs. }\end{array}$ & $\begin{array}{l}\text { UP2: Receive Drums or boxes - } \\
\text { user can substitute IDs but cannot } \\
\text { modify }\end{array}$ & $\begin{array}{l}\text { phrasing in SRS may be wrong - should } \\
\text { verify that intent is to modify PIN list } \\
\text { and actual PINs }\end{array}$ & $\begin{array}{l}\text { 2/20/96: Text Proc Review } \\
\text { Session: SRS needs to be } \\
\text { updated - modification is to } \\
\text { list by add/delete of PINs - } \\
\text { individual PIN is not subject } \\
\text { to editing } \\
\text { Action Completed and } \\
\text { Discrepancy Item Closed: } \\
\text { 2/28/96 }\end{array}$ \\
\hline
\end{tabular}




\begin{tabular}{|c|c|c|c|c|}
\hline SRS REFERENCE & REQUIREMENT & DISCREPANCY & RATIONALE FOR CATEGORY & RESOLUTION \\
\hline $\begin{array}{l}\text { 3.1.1.2.2 Confirm Data } \\
\text { on SWITS }\end{array}$ & $\begin{array}{l}\text { Generate system status messages } \\
\text { on the "Receiving" screen. }\end{array}$ & $\begin{array}{l}\text { no indication of "system status" } \\
\text { messages - only error messages } \\
\text { for PIN comparisons }\end{array}$ & $\begin{array}{l}\text { may be missing necessary screen } \\
\text { information }\end{array}$ & $\begin{array}{l}\text { 2/20/96: Text Proc Review } \\
\text { Session: SRS needs to be } \\
\text { updated to rephrase term } \\
\text { "system status" messages - } \\
\text { the error messages in } \\
\text { Appendix F are appropriate } \\
\text { Action Completed and } \\
\text { Discrepancy Item Closed: } \\
\text { 2/28/96 }\end{array}$ \\
\hline $\begin{array}{l}\text { 3.1.1.2.2 Confirm Data } \\
\text { on SWITS } \\
\text { 3.1.1.2.5 Generate DMS } \\
\text { Drum or Box Container } \\
\text { Records }\end{array}$ & $\begin{array}{l}\text { Generate an alarm on the } \\
\text { "Receiving" screen if the facility } \\
\text { dose equivalent curie limit is } \\
\text { exceeded. (Pop-up screen from } \\
\text { Section 3.1.7.2.3) }\end{array}$ & $\begin{array}{l}\text { during TRU glovebox, alarm is } \\
\text { generated when limits exceed } 90 \%\end{array}$ & $\begin{array}{l}\text { reactive vs, proactive? (is it too late to } \\
\text { alarm after level exceeded?) }\end{array}$ & $\begin{array}{l}\text { 2/20/96: Text Proc Review } \\
\text { Session: during the TRU } \\
\text { specification development } \\
\text { (Phase 2), a "limit" will be } \\
\text { established - this may be at } \\
\text { some point below a } \\
\text { maximum safe level - } \\
\text { regardless, the limit } \\
\text { specified there will be } \\
\text { applied to this UP - } \\
\text { Discrepancy Item Closed }\end{array}$ \\
\hline
\end{tabular}




\begin{tabular}{|c|c|c|c|c|}
\hline SRS REFERENCE & REQUIREMENT & DISCREPANCY & RATIONALE FOR CATEGORY & RESOLUTION \\
\hline $\begin{array}{l}\text { 3.1.1.2.4 Retrieve Drum } \\
\text { or Box. Container Data } \\
\text { from SWITS }\end{array}$ & $\begin{array}{l}\text { Display the "request for } \\
\text { certification data" message on } \\
\text { the "Container Receiving" } \\
\text { screen. }\end{array}$ & no such message specified & $\begin{array}{l}\text { may be missing necessary screen } \\
\text { information }\end{array}$ & $\begin{array}{l}\text { 2/20/96: Text Proc Review } \\
\text { Session: the message } \\
\text { originally planned has been } \\
\text { superseded by the design of } \\
\text { system buttons Discrepancy } \\
\text { Item Closed }\end{array}$ \\
\hline $\begin{array}{l}\text { 3.1.2.1.1 Drum or Box } \\
\text { Container NDE Data }\end{array}$ & $\begin{array}{l}\text { User request for the dnum or box } \\
\text { located at one of the NDE drum } \\
\text { or box vaults (container PIN } \\
\text { number provided automatically } \\
\text { from DMS database) }\end{array}$ & $\begin{array}{l}\text { cannot find a message that } \\
\text { transmits location NDE_A or } \\
\text { NDE_B for drums }\end{array}$ & $\begin{array}{l}\text { unclear how CONLOC_LOCN_ID is set } \\
\text { for use by 3.1.2.1/UP1 screening }\end{array}$ & $\begin{array}{l}\text { This is a PCSDMS-CL } \\
\text { message transmitted per } \\
\text { NetComm 3.1. Discrepancy } \\
\text { Item Closed } 4 / 10 / 96\end{array}$ \\
\hline \multirow[t]{2}{*}{$\begin{array}{l}\text { 3.1.2.1.2 Drum or Box } \\
\text { Container NDE Results }\end{array}$} & $\begin{array}{l}\text { NDE user conments, image } \\
\text { information, verified/not verified } \\
\text { status, and compliant/non- } \\
\text { compliant status are added as } \\
\text { inputs to the drum or box } \\
\text { container "NDE" screen. }\end{array}$ & \multirow{2}{*}{$\begin{array}{l}\text { 3.1.2.1/UP1\&2 - specifications do } \\
\text { not cite editing permission for } \\
\text { user to change displayed data - } \\
\text { states "Header (Display Only)" } \\
\text { specifications restrict user } \\
\text { edit/entry to creation of new } \\
\text { records - SRS does not } \\
\text { differentiate between new and } \\
\text { existing records and implies user } \\
\text { entry OK for both }\end{array}$} & \multirow[t]{2}{*}{$\begin{array}{l}\text { provisions for edit and display only for } \\
\text { data may not be current with } \\
\text { tequirements }\end{array}$} & \multirow{2}{*}{$\begin{array}{l}\text { Comments provided after } \\
\text { review of V\&V } \\
\text { discrepancies: SRS needs } \\
\text { to be modified to replace } \\
\text { "updates" with "inputs" - } \\
\text { the "Header (display only)" } \\
\text { in UP } 2 / 3 \text { is for popups of } \\
\text { SWITS data which are read } \\
\text { only } \\
\text { Action Completed and } \\
\text { Discrepancy Item Closed } \\
\text { as of } 3 / 6 / 96\end{array}$} \\
\hline & $\begin{array}{l}\text { Add the NDE user input to the } \\
\text { DMS database against that drum } \\
\text { or box container PIN. }\end{array}$ & & & \\
\hline
\end{tabular}




\begin{tabular}{|c|c|c|c|c|}
\hline SRS REFERENCE & REQUIREMENT & DISCREPANCY & RATIONALE FOR CATEGORY & RESOLUTION \\
\hline & $\begin{array}{l}\text { Display the confirmation of the } \\
\text { NDE user update to the DMS } \\
\text { database. }\end{array}$ & $\begin{array}{l}\text { 3.1.8/UP2-5: no specific } \\
\text { confirmation message or feedback } \\
\text { - dependent on what user sees - if } \\
\text { user does create or modify } \\
\text { records, allows save with } \\
\text { signature/password, but no } \\
\text { "Commit Button" - save on } \\
\text { "Exit"? }\end{array}$ & $\begin{array}{l}\text { does not seem to completely address } \\
\text { requirements }\end{array}$ & $\begin{array}{l}\text { Comments provided after } \\
\text { review of V\&V } \\
\text { discrepancies: SDD } \\
\text { modified to add Commit } \\
\text { button and delete } \\
\text { requirement for signature } \\
\text { password } \\
\text { Discrepancy Item Closed }\end{array}$ \\
\hline $\begin{array}{l}\text { 3.1.2.2.1 Drum or Box } \\
\text { Container NDA Data } \\
\text { Revisit }\end{array}$ & $\begin{array}{l}\text { send waste characterization data } \\
\text { and isotopic data to BWAS with } \\
\text { purpose of assay, REVISIT }\end{array}$ & $\begin{array}{l}\text { 3.1.8/UP12, 98: send generic BD } \\
\text { message - so specific purpose } \\
\text { "REVISIT" occurrence specified }\end{array}$ & $\begin{array}{l}\text { may be missing a needed message } \\
\text { occurrence }\end{array}$ & $\begin{array}{l}\text { Comments provided after } \\
\text { review of V\&V } \\
\text { discrepancies: the } \\
\text { REVISIT message initiated } \\
\text { by the } 202 \text { screen - BWAS } \\
\text { messages to be implemented } \\
\text { in Phase } 2 \text { - Appendix F } \\
3.1 .2 .2 \text { will be revised to } \\
\text { add BD message to BWAS }\end{array}$ \\
\hline
\end{tabular}




\begin{tabular}{|c|c|c|c|c|}
\hline SRS REFERENCE & REQUIREMENT & DISCREPANCY & RATIONALE FOR CATEGORY & RESOLUTION \\
\hline \multirow[t]{2}{*}{$\begin{array}{l}\text { 3.1.2.2.2 Drum or Box } \\
\text { Container NDA Results }\end{array}$} & $\begin{array}{l}\text { Criticality alert message and } \\
\text { Non-Listed Long Lived nuclide } \\
\text { detected messages may be } \\
\text { received from the SIE or BWAS. }\end{array}$ & $\begin{array}{l}\text { CRIT and NLLL messages } \\
\text { received via DMSCOM - data } \\
\text { base updated - no indication } \\
3.1 .2 .2 \text { of awareness of CRIT } \\
\text { message receipt - NLLL displayed } \\
\text { as part of data base record read - } \\
\text { unclear if NDA module should be } \\
\text { reacting in real time with message } \\
\text { traffic }\end{array}$ & $\begin{array}{l}\text { timeliness of data display may be in } \\
\text { question }\end{array}$ & $\begin{array}{l}\text { Comments provided after } \\
\text { review of V\&V } \\
\text { discrepancies: SRS revised } \\
\text { to delete reference to } \\
\text { criticality alert message - the } \\
\text { NLLL message should be } \\
\text { received prior to the RESS } \\
\text { message so should not be a } \\
\text { problem with timeliness } \\
\text { Action Completed and } \\
\text { Discrepancy Item Closed } \\
\text { as of } 3 / 6 / 96\end{array}$ \\
\hline & $\begin{array}{l}\text { User request to view assay } \\
\text { results for specific drum or box. }\end{array}$ & $\begin{array}{l}\text { UP3 specifies a NDA Results } \\
\text { which generates an NDA pop-up } \\
\text { containing NDA record - shown } \\
\text { for initial DMSSO202 but only } \\
\text { specified in UP3 which is for } \\
\text { Revisit }\end{array}$ & $\begin{array}{l}\text { use of NDA Results button should be } \\
\text { specified for all instances - may just } \\
\text { reflect current placement in Appendix F }\end{array}$ & $\begin{array}{l}\text { Comments provided after } \\
\text { review of V\&V } \\
\text { discrepancies: SDD needs } \\
\text { to be revised } \\
\text { Action Completed and } \\
\text { Discrepancy Item Closed } \\
\text { as of } 3 / 6 / 96\end{array}$ \\
\hline
\end{tabular}




\begin{tabular}{|c|c|c|c|c|}
\hline SRS REFERENCE & REQURREMENT & DISCREPANCY & RATIONALE FOR CATEGORY & RESOLUTION \\
\hline & User entry of comments. & $\begin{array}{l}\text { UPI specifies display of Generator } \\
\text { Comments - no specification for } \\
\text { edit or entry of comments }\end{array}$ & $\begin{array}{l}\text { read vs. edit rights and screen interaction } \\
\text { may not support requirements }\end{array}$ & $\begin{array}{l}\text { Comments provided after } \\
\text { review of V\&V } \\
\text { discrepancies: Generator } \\
\text { Comments are on read only } \\
\text { - SDD to be revised } \\
\text { Action Completed and } \\
\text { Discrepancy Item Closed } \\
\text { 3/6/96 }\end{array}$ \\
\hline . & $\begin{array}{l}\text { If Non-Listed Long Live nuclide } \\
\text { detected message is received save } \\
\text { this data in the database. }\end{array}$ & $\begin{array}{l}\text { Appendix F specifies setting } \\
\text { NDA_NONLISED_FLAG - this } \\
\text { data element does not exist } \\
\text { 3.1.8 SIE and BWAS NLLL } \\
\text { messages set CONEXT_NLLL_ } \\
\text { DETECTED = system date but } \\
\text { Appendix C specifies the domain } \\
\text { as either Y or N } \\
\text { SIE message sets } \\
\text { MSGLOG_INIT_FLAG to DF but } \\
\text { this has been deleted from } \\
\text { Appendix C }\end{array}$ & $\begin{array}{l}\text { need to verify specification for NLLL } \\
\text { message and subsequent update to data } \\
\text { base }\end{array}$ & $\begin{array}{l}\text { Comments provided after } \\
\text { review of V\&V } \\
\text { discrepancies: SDD to be } \\
\text { revised to reflect } \\
\text { CONEXT_NLLL_ } \\
\text { DET_DT } \\
\text { Action Completed and } \\
\text { Discrepancy Item Closed } \\
\text { as of } 3 / 6 / 96\end{array}$ \\
\hline
\end{tabular}




\begin{tabular}{|c|c|c|c|c|}
\hline SRS REFERENCE & REQUIREMENT & DISCREPANCY & RATIONALE FOR CATEGORY & RESOLUTION \\
\hline $\begin{array}{l}\text { 3.1.3.1.1 LLW Entry } \\
\text { Glovebox }\end{array}$ & $\begin{array}{l}\text { input: User requests "LLW } \\
\text { Glovebox - Drum Status at } \\
\text { Entry" from the "Process } \\
\text { Operations" menu }\end{array}$ & $\begin{array}{l}\text { user request screen (DMSSO311) } \\
\text { from LLW Drum Process Menu - } \\
\text { Process Menu actually on Main } \\
\text { Menu }\end{array}$ & menu hieraxchy should be validated & $\begin{array}{l}\text { refer to the Main Menu } \\
\text { discussion in V\&V Report } \\
\text { Appendix B }\end{array}$ \\
\hline $\begin{array}{l}\text { 3.1.3.1.3 LLW Sorting } \\
\text { Glovebox Sorting Table } \\
\text { Operations }\end{array}$ & $\begin{array}{l}\text { input: PINs of the drum at the } \\
\text { sorting table and the drum at the } \\
\text { compliant waste load out port }\end{array}$ & $\begin{array}{l}\text { no specification differentiating } \\
\text { between a drum at the sort table } \\
\text { and a drum at the compliant waste } \\
\text { load out port - only the sorting } \\
\text { table drum PIN seems to be } \\
\text { displayed }\end{array}$ & processing may not support requirement & $\begin{array}{l}\text { 1/30/96: Test Proc Review } \\
\text { Meet: SRS contains a typo } \\
\text { and should be updated - } \\
\text { action shown in LLW non- } \\
\text { compliant pop up } \\
\text { Action Completed and } \\
\text { Discrepancy Item Closed } \\
\text { as of } 3 / 6 / 96\end{array}$ \\
\hline $\begin{array}{l}\text { 3.1.3.1.6 LLW } \\
\text { Compactor/Storage }\end{array}$ & $\begin{array}{l}\text { The original PIN will be retained } \\
\text { for tracking of data in the DMS. } \\
\text { Puck weight is recorded when } \\
\text { the puck is first lifted by the } \\
\text { puck grapple. }\end{array}$ & $\begin{array}{l}\text { specifies weight calculations - SRS } \\
\text { has no inputs/processing/outputs } \\
\text { described in detail }\end{array}$ & $\begin{array}{l}\text { calculations should be verified against } \\
\text { requirements }\end{array}$ & $\begin{array}{l}\text { 1/30/96: Test Proc Review } \\
\text { Meet: SRS should be } \\
\text { updated - the SDD has the } \\
\text { current information }\end{array}$ \\
\hline
\end{tabular}




\begin{tabular}{|c|c|c|c|c|}
\hline SRS REFERENCE & REQUIREMENT & DISCREPANCY & RATIONALE FOR CATEGORY & RESOLUTION \\
\hline $\begin{array}{l}\text { 3.1.3.1.7 Load } \\
\text { out/Storage of LLW Feed } \\
\text { Drums/Pucks }\end{array}$ & $\begin{array}{l}\text { The puck or drum is picked up } \\
\text { by the grapple from the } \\
\text { compactor discharge position or } \\
\text { a storage location and the weight } \\
\text { read by the PCS is transferred to } \\
\text { the DMS. } \\
\text { When the drum or puck is placed } \\
\text { in the product drum, a message } \\
\text { relating the over packed drum or } \\
\text { puck and the load out drum is } \\
\text { sent from the PCS to the DMS. }\end{array}$ & $\begin{array}{l}\text { weight and other drum and puck } \\
\text { information is calculated - user } \\
\text { entries are specified - receive } \\
\text { message PCSDMS POPD - SRS } \\
\text { has no inputs/processes/outputs } \\
\text { described in detail }\end{array}$ & $\begin{array}{l}\text { calculations should be verified against } \\
\text { requirements }\end{array}$ & $\begin{array}{l}\text { 1/30/96: Test Proc Review } \\
\text { Meet: SRS should be } \\
\text { updated - the SDD has the } \\
\text { current information }\end{array}$ \\
\hline \multirow[t]{2}{*}{$\begin{array}{l}\text { 3.1.3.1.8 LLW Glovebox } \\
\text { Product Drum Content } \\
\text { Inventory Update }\end{array}$} & $\begin{array}{l}\text { User requests the "Exit } \\
\text { Glovebox" screen from the } \\
\text { "Process Operations - LLW } \\
\text { Glovebox" menu. }\end{array}$ & LLW Process menu not specified & menu hierarchy should be validated & $\begin{array}{l}\text { refer to the Main Menu } \\
\text { review in V\&V Report } \\
\text { Appendix B }\end{array}$ \\
\hline & input: User Signature Password & $\begin{array}{l}\text { specifies validation of } \\
\text { signature/password when } \\
\text { "Commit" button selected by user } \\
\text { - no indication of when } \\
\text { signature/password is entered } \\
\text { except in UP2 }\end{array}$ & $\begin{array}{l}\text { security measure may not match needs of } \\
\text { operation }\end{array}$ & $\begin{array}{l}\text { 1/30/96: Test Proc Review } \\
\text { Meet: the parent screen } \\
\text { signature password applies - } \\
\text { refer to the signature } \\
\text { password matrix in V\&V } \\
\text { Report Appendix B }\end{array}$ \\
\hline
\end{tabular}




\begin{tabular}{|c|c|c|c|c|}
\hline SRS REFERENCE & REQUIREMENT & DISCREPANCY & RATIONALE FOR CATEGORY & RESOLUTION \\
\hline & $\begin{array}{l}\text { Combine contents inventories of } \\
\text { all puck/drum containers placed } \\
\text { in the product drum into one list. }\end{array}$ & $\begin{array}{l}\text { calculates " } 100 \text { times the } \\
\text { compacted height of each } \\
\text { PHYSCOMP" then sums the } \\
\text { PHYSCOMP_PUCKS for all like } \\
\text { PHYSCOMP_DESCR - source of } \\
\text { "100 times height"? may be an } \\
\text { SRS omission }\end{array}$ & $\begin{array}{l}\text { calculations should be verified against } \\
\text { requirements }\end{array}$ & $\begin{array}{l}\text { 1/30/96: Test Proc Review } \\
\text { Meet: SRS should be } \\
\text { updated - the SDD has the } \\
\text { current information }\end{array}$ \\
\hline $\begin{array}{l}\text { 3.1.3.2.1 LLW RWM } \\
\text { Separate Compliant from } \\
\text { Non-compliant }\end{array}$ & input user Signature Password & $\begin{array}{l}\text { App F - 3.1.3.2/UP1: requires } \\
\text { signature password when user } \\
\text { selects Commit button - however, } \\
\text { no "commit" operations for UP2 }\end{array}$ & $\begin{array}{l}\text { unclear how UPs and screens interact } \\
\text { with each other - seems to imply that } \\
\text { higher level signature password is used at } \\
\text { lower level process }\end{array}$ & $\begin{array}{l}\text { Note signature password } \\
\text { review matrix in V\&V } \\
\text { Report Appendix B. To be } \\
\text { addressed during SDD } \\
\text { update after Phase } 2 \\
\text { function specification review }\end{array}$ \\
\hline
\end{tabular}




\begin{tabular}{|c|c|c|c|c|}
\hline SRS REFERENCE & REQUIREMENT & DISCREPANCY & RATIONALE FOR CATEGORY & RESOLUTION \\
\hline \multirow[t]{2}{*}{$\begin{array}{l}\text { 3.1.3.2.6 Perform Waste } \\
\text { Treatment }\end{array}$} & $\begin{array}{l}\text { Commit the data collected on the } \\
\text { "LLW RWM Treatment" screen } \\
\text { to the DMS database after } \\
\text { signature password has been } \\
\text { entered. }\end{array}$ & $\begin{array}{l}\text { UP15-16: Compliant Waste } \\
\text { Loadout - BOTTLE, } \\
\text { CONTREAT, CONREL, } \\
\text { SAMREL, WASTEXT records } \\
\text { created with signature password } \\
\text { required for Commit }\end{array}$ & $\begin{array}{l}\text { UP14: Items are treated and waste } \\
\text { records populated - three records are } \\
\text { created as an extension of processing - } \\
\text { unclear if signature password is } \\
\text { considered }\end{array}$ & $\begin{array}{l}\text { See signature password } \\
\text { matrix in Appendix B of } \\
\text { V\&V Report. To be } \\
\text { addressed during SDD } \\
\text { update after Phase } 2 \\
\text { function specification review }\end{array}$ \\
\hline & input user Signature Password & $\begin{array}{l}\text { App F - 3.1.3.2/UP 5\&6: } \\
\text { requires signature/password when } \\
\text { user selects Next New Container } \\
\text { and database updated; and when } \\
\text { user selects Return To Sorting - } \\
\text { refers to screens } 0321 \text { and } 0322 \text { - } \\
0322 \text { does not have signature } \\
\text { password - implies using the } \\
\text { signature password entered on } \\
0321 \text { ? }\end{array}$ & $\begin{array}{l}\text { unclear when actual signature password } \\
\text { is needed and how the screens relate in } \\
\text { using the information }\end{array}$ & $\begin{array}{l}\text { note signature password } \\
\text { review matrix in V\&V } \\
\text { Report Appendix B }\end{array}$ \\
\hline
\end{tabular}




\begin{tabular}{|c|c|c|c|c|}
\hline SRS REFERENCE & REQUTREMENT & DISCREPANCY & RATIONALE FOR CATEGORY & RESOLUTION \\
\hline & $\begin{array}{l}\text { Display transfer drum PIN and } \\
\text { PINs for all items to be removed } \\
\text { from transfer drum on RWM } \\
\text { glovebox DMS monitor. } \\
\text { Indicate when each PIN has been } \\
\text { removed from drum. }\end{array}$ & $\begin{array}{l}\text { UP9-10: LLWRWM Staging of } \\
\text { Items to be Treated - displays all } \\
\text { information except when } \\
\text { packet/sample removed from } \\
\text { transfer drum }\end{array}$ & $\begin{array}{l}\text { seems to be missing information on } \\
\text { timing }\end{array}$ & \\
\hline \multirow[t]{2}{*}{$\begin{array}{l}\text { 3.1.3.3.1 TRU Entry } \\
\text { Glovebox }\end{array}$} & $\begin{array}{l}\text { "Drum Contamination Status" } \\
\text { message from the PCS. }\end{array}$ & $\begin{array}{l}\text { UP1: TRU glovebox drum status } \\
\text { at entry - no mention of relation to } \\
\text { DCS - } 3.1 .8 / \text { UP60 specifies a } \\
\text { DCS message - TRU module does } \\
\text { not use the } \\
\text { CONEXT_CONTAM_FLAG the } \\
\text { DCS message updates - however, } \\
\text { DCS message may be source of } \\
\text { drum PIN associated with location } \\
\text { TRU_SORT }\end{array}$ & $\begin{array}{l}\text { unclear if DCS interacts with TRU } \\
\text { process or how the two relate to their } \\
\text { respective data base updates }\end{array}$ & \multirow[t]{2}{*}{$\begin{array}{l}\text { 2/20/96: Test Proc Review } \\
\text { Meet: TRU process to be } \\
\text { further specified during } \\
\text { Phase } 3 \text { requirement reviews } \\
\text { and subsequent specification } \\
\text { updates. TRU and TRU } \\
\text { RWM discrepancies will be } \\
\text { addressed during those } \\
\text { activities }\end{array}$} \\
\hline & $\begin{array}{l}\text { User requests "TRU Glovebox - } \\
\text { Drum Status at Entry" from the } \\
\text { "Process Operations" menu }\end{array}$ & UP1 has the TRU Entry screen & $\begin{array}{l}\text { may have superseded the original intent } \\
\text { of the SRS }\end{array}$ & \\
\hline
\end{tabular}




\begin{tabular}{||l|l|l||l|}
\hline \multicolumn{1}{|c|}{ SRS REFERENCE } & \multicolumn{1}{|c|}{ REQUIREMENT } & \multicolumn{1}{|c|}{ DISCREPANCY } & RATIONALE FOR CATEGORY \\
\hline \hline $\begin{array}{l}\text { 3.1.3.3.2 TRU Sorting } \\
\text { Glovebox Sorting Table } \\
\text { Operations }\end{array}$ & $\begin{array}{l}\text { PINs of drum at the sorting table } \\
\text { and the drums at the two } \\
\text { compliant loadout ports received } \\
\text { from the PCS. }\end{array}$ & $\begin{array}{l}\text { UP3: TRU Sorting Table - } \\
\text { displays PINS at sorting table - no } \\
\text { specification for drums at } \\
\text { compliant loadout ports }\end{array}$ & $\begin{array}{l}\text { UP does not seem to incorporate all } \\
\text { necessary information }\end{array}$ \\
\hline $\begin{array}{l}\text { 3.1.3.3.3 TRU Sorting } \\
\text { Wavebox Non-compliant Loadout }\end{array}$ & $\begin{array}{l}\text { The PAM unit will perform a } \\
\text { packet assay and report a PLi-240 } \\
\text { equivalent value (along with } \\
\text { uncertainty) to the PCS which } \\
\text { then transfers the data to the } \\
\text { DMS. }\end{array}$ & $\begin{array}{l}\text { UP5: TRU Non-Compliant } \\
\text { Packet - screen will display FGE } \\
\text { data - PAMR message specifies } \\
\text { display of FGE in a pop-up } \\
\text { window with an OK button - } \\
\text { overlap? }\end{array}$ & $\begin{array}{l}\text { screens may be redundant or in conflict } \\
\text { with each other }\end{array}$ \\
\cline { 2 - 5 } & $\begin{array}{l}\text { Display the attached RWM } \\
\text { transfer drum cumulative Pu-239 } \\
\text { FGE value. }\end{array}$ & $\begin{array}{l}\text { UP5: TRU Non-Compliant } \\
\text { Packet - FGE seems to be } \\
\text { displayed only for the packets in } \\
\text { the drum - does not seem to be a } \\
\text { drum "roll up" for total FGE }\end{array}$ & may be missing necessary data on screen \\
\hline
\end{tabular}




\begin{tabular}{|c|c|c|c|c|}
\hline SRS REFERENCE & REQUTREMENT & DISCREPANCY & RATIONALE FOR CATEGORY & RESOLUTION \\
\hline $\begin{array}{l}\text { 3.1.4 Sample } \\
\text { Management: general } \\
\text { discrepancy }\end{array}$ & none & $\begin{array}{l}\text { following screens are specified in } \\
\text { SDD Appendix F, but can not be } \\
\text { mapped to any SRS requirement: } \\
\text { DMSS0507: Sample } \\
\text { Management/COC } \\
\text { DMSS0508: Sample Labels } \\
\text { DMSS0509: Sample/Bottle } \\
\text { Tracking Data } \\
\text { DMSS0510: Purge Port/ } \\
\text { Transfer Pig Location }\end{array}$ & $\begin{array}{l}\text { not clear if these fulfill a later identified } \\
\text { requirement or if they are an increase in } \\
\text { scope }\end{array}$ & $\begin{array}{l}\text { These screens were } \\
\text { identified in the SDD during } \\
\text { design as being required to } \\
\text { fulfill Sample Management } \\
\text { functions. SRS to be } \\
\text { updated following Phase } 2 \\
\text { functional specification } \\
\text { review meeting. } \\
\text { Discrepancy Item Closed } \\
\text { 4/10/96 }\end{array}$ \\
\hline $\begin{array}{l}\text { 3.1.4.4 Waste } \\
\text { Designation }\end{array}$ & $\begin{array}{l}\text { Packet PIN selected by user from } \\
\text { list of all packets stored in } \\
\text { transfer drums if screen is } \\
\text { accessed from "Sample } \\
\text { Management" menu or } \\
\text { "Worksheet Data Entry" screen, } \\
\text { or from list of packets in } \\
\text { previously selected product } \\
\text { drum if screen is accessed from } \\
\text { "Processed Waste Data Review } \\
\text { and Modification" screen. }\end{array}$ & $\begin{array}{l}\text { UP10: Designation of packet } \\
\text { waste characteristics in support of } \\
\text { generation of the worksheet } \\
\text { info/future treatment specifies } \\
\text { required data from DMSSO506 } \\
\text { and DMSS1221 selections } \\
\text { no mention of display if selected } \\
\text { from Sample Management menu - } \\
\text { superseded by requirement to } \\
\text { select DMSSOS06? }\end{array}$ & $\begin{array}{l}\text { screen hierarchy needs to be clarified in } \\
\text { the SRS }\end{array}$ & $\begin{array}{l}\text { To be addressed during } \\
\text { SDD update after Phase } 2 \\
\text { function specification review }\end{array}$ \\
\hline
\end{tabular}




\begin{tabular}{|c|c|c|c|c|}
\hline SRS REFERENCE & REQUIREMENT & DISCREPANCY & RATIONALE FOR CATEGORY & RESOLUTION \\
\hline & $\begin{array}{l}\text { Worksheet Number, PIN of } \\
\text { container(s) to be treated, WRAP } \\
1 \text { treatment procedure number, } \\
\text { TRU or LLW indicator, and file } \\
\text { name of ASCII file to be } \\
\text { displayed on monitor behind } \\
\text { appropriate RWM glovebox. } \\
\text { Verify that for all samples to be } \\
\text { treated, if any, results have been } \\
\text { received. Refer to SRS section } \\
3.1 .3 .2 .6 \text { for application of } \\
\text { treatment process. }\end{array}$ & $\begin{array}{l}\text { UP12: Generation of Worksheet } \\
\text { data in support of RWM } \\
\text { Processing - Display all currently } \\
\text { defined worksheets } \\
\text { UP14: Display packets available } \\
\text { for treatment on a pop-up screen } \\
\text { required data displayed but packet } \\
\text { data displayed only when user } \\
\text { selects Add Packet button }\end{array}$ & $\begin{array}{l}\text { data display may not be complete on } \\
\text { basic screen }\end{array}$ & \\
\hline $\begin{array}{l}\text { 3.1.4.5 Treatment } \\
\text { Worksheet Entry }\end{array}$ & $\begin{array}{l}\text { Perform input validation. } \\
\text { Worksheet number field must be } \\
\text { unique. Container type must be } \\
\text { sample, packet, collection } \\
\text { container or treatment container. } \\
\text { Procedure entered must be a } \\
\text { valid treatment procedure. File } \\
\text { name entered must already exist. } \\
\text { TRU or LLW indicator must } \\
\text { correspond to the secondary } \\
\text { waste type. Treatment procedure } \\
\text { is checked to make sure it is not } \\
\text { expired. }\end{array}$ & $\begin{array}{l}\text { display and data retrievals are } \\
\text { based on record keys for tables } \\
\text { accessed - no specification for } \\
\text { validation/edit checks for data } \\
\text { entry }\end{array}$ & $\begin{array}{l}\text { specifications should indicate that edit } \\
\text { checks occur, but generally do not } \\
\text { throughout the SDD - this is one of the } \\
\text { few SRS requirements that go out the } \\
\text { way to mention them -validation checking } \\
\text { seems to be implied in the semantics of } \\
\text { the SDD pseudo-code - perhaps should } \\
\text { be part of the general design } \\
\text { specifications? }\end{array}$ & $\begin{array}{l}\text { To be clarified in the next } \\
\text { revision of the SRS. } \\
\text { Specific edit checks to be } \\
\text { defined in } B C S R \text { as-built } \\
\text { release of SDD }\end{array}$ \\
\hline
\end{tabular}




\begin{tabular}{|c|c|c|c|c|}
\hline SRS REFERENCE & REQUIREMENT & DISCREPANCY & RATIONALE FOR CATEGORY & RESOLUTION \\
\hline & $\begin{array}{l}\text { Display the "Treatment Process } \\
\text { Entry" screen with the treatment } \\
\text { number and description. }\end{array}$ & no such screen & $\begin{array}{l}\text { a reference back to DMSS0506 with an } \\
\text { old/erroneous screen name? }\end{array}$ & - \\
\hline \multirow[t]{2}{*}{$\begin{array}{l}\text { 3.1.5.1 Generate Drum or } \\
\text { Box Documentation }\end{array}$} & $\begin{array}{l}\text { Manually entered data to } \\
\text { complete shipping forms }\end{array}$ & $\begin{array}{l}\text { UPs } 2-6 \text { specify displays of } \\
\text { various information for form, with } \\
\text { lookups to tables - user entry } \\
\text { specified only for Special Nuclear } \\
\text { Material (Y or N), To } \\
\text { Building/Area, From } \\
\text { Building/Area columns, etc. - } \\
\text { most is display only }\end{array}$ & $\begin{array}{l}\text { SRS is not specific on data to be entered } \\
\text { and/or displayed only - specifications } \\
\text { may need a final verification to ensure } \\
\text { all necessary data entry can be } \\
\text { accomplished }\end{array}$ & $\begin{array}{l}\text { Comments provided after } \\
\text { review of } V \& V \\
\text { discrepancies: shipping } \\
\text { documentation to be } \\
\text { reviewed during Phase } 2\end{array}$ \\
\hline & Print the proper shipping reports. & $\begin{array}{l}\text { UP1: Selection of WRAP } \\
\text { shipment form to be completed - } \\
\text { has a Print Button - selection of a } \\
\text { particular report button enables } \\
\text { print button, but apparently have } \\
\text { to return to } 0601 \text { each time to } \\
\text { print each report, one at a time - } \\
\text { no indication of return to } 0601 \text { for } \\
\text { printing when user selects Exit or } \\
\text { Manifest Complete buttons }\end{array}$ & $\begin{array}{l}\text { may be an awkward user interaction with } \\
\text { screen flow - no way to print all at once }\end{array}$ & $\begin{array}{l}\text { Comments provided after } \\
\text { review of } V \& V \\
\text { discrepancies: shipping } \\
\text { documentation to be } \\
\text { reviewed during Phase } 2\end{array}$ \\
\hline
\end{tabular}




\begin{tabular}{|c|c|c|c|c|}
\hline SRS REFERENCE & REQUIREMENT & DISCREPANCY & RATIONALE FOR CATEGORY & RESOLUTION \\
\hline \multirow[t]{2}{*}{$\begin{array}{l}\text { 3.1.5.2.1 Requesting } \\
\text { Retrieval of Drums for } \\
\text { Shipment }\end{array}$} & $\begin{array}{l}\text { PINs of drums at the shipping } \\
\text { dock received from the PCS. }\end{array}$ & $\begin{array}{l}\text { UP10: Update the container } \\
\text { location as containers are removed } \\
\text { from storage and transferred to } \\
\text { the shipping dock - specifies CL } \\
\text { message with SHIPDCK location } \\
\text { as trigger to refresh screen only } \\
\text { for the WRAP Shipment Number } \\
\text { already displayed in UP9 }\end{array}$ & $\begin{array}{l}\text { PIN display from PCS limited to current } \\
\text { WRAP Shipment Number - no others } \\
\text { displayed - SRS requirement seems to be } \\
\text { intended to identify new PINs to process } \\
\text { for next shipment, but full intent is not } \\
\text { clear }\end{array}$ & $\begin{array}{l}\text { Publication of new SDD: } \\
\text { Appendix F changes address } \\
\text { this discrepancy } \\
\text { Discrepancy Item Closed } \\
\text { as of } 4 / 15 / 96\end{array}$ \\
\hline & $\begin{array}{l}\text { Update drum or box location to } \\
\text { shipping dock. (Section } 3.1 .8 \text { ) }\end{array}$ & $\begin{array}{l}\text { UP10 specifies a DMSCOM } \\
\text { trigger to form for PCSDMS CL } \\
\text { (SHIPDCK) which causes screen } \\
\text { to refresh with SHIPDCK located } \\
\text { PINs that match } \\
\text { SHIPPICK_WRAP_- } \\
\text { NUM - SRS paragraph } 3.1 .8 \\
\text { discuss location updates in } \\
\text { general, but has no reference to } \\
\text { location updates pertaining to } \\
\text { shipping except for IN_TRANSIT } \\
\text { - other messages update locations } \\
\text { which are associated with the } \\
\text { shipping dock (such as } \\
\text { DISCHRVW), but actual } \\
\text { SHPDCK location code does not } \\
\text { seem to be set }\end{array}$ & $\begin{array}{l}\text { trigger may not be set and data retrieval } \\
\text { may not occur }\end{array}$ & $\begin{array}{l}\text { Follow up information: } \\
\text { updates of locations occur } \\
\text { by DMSCOM in } \\
\text { "background" and may not } \\
\text { always affect other data base } \\
\text { processing - Appendix F } \\
\text { messages relate to } \\
\text { DMSCOM traffic that } \\
\text { affects other processes } \\
\text { Discrepancy Item Closed: } \\
\text { 3/15/96 }\end{array}$ \\
\hline
\end{tabular}




\begin{tabular}{|c|c|c|c|c|}
\hline SRS REFERENCE & REQUIREMENT & DISCREPANCY & RATIONALE FOR CATEGORY & RESOLUTION \\
\hline $\begin{array}{l}\text { 3.1.5.2.2 Certification } \\
\text { Data to SWITS }\end{array}$ & $\begin{array}{l}\text { A request by the user to transmit } \\
\text { certification data and the location } \\
\text { update information on the } \\
\text { pending shipment shown on the } \\
\text { "Loading Dock Container } \\
\text { Shipping" screen to SWITS. } \\
\text { This request is performed from } \\
\text { the "Loading Dock Container } \\
\text { Shipping" screen. }\end{array}$ & $\begin{array}{l}\text { UP11: DMS to transmit } \\
\text { applicable SWITS data to SWITS } \\
\text { for all drums sent to the } \\
\text { Processing Area in WRAP and } \\
\text { UP12: DMS to transmit all } \\
\text { applicable SWITS data to SWITS } \\
\text { for all drums received by WRAP } \\
\text { specify selection of In Transit } \\
\text { button - updates SWITS tables }\end{array}$ & $\begin{array}{l}\text { "in transit" implies drums bave left the } \\
\text { facility - requirement seems to be } \\
\text { oriented toward drums still in the facility } \\
\text { and pending transit }\end{array}$ & $\begin{array}{l}\text { 05/02/96: Test Proc } \\
\text { Review Meet: Update to } \\
\text { SWITS occurs only when } \\
\text { containers actually leave } \\
\text { WRAP - so they are } \\
\text { IN_TRANSIT - if SWITS } \\
\text { rejects update, receiving } \\
\text { facility will not be able to } \\
\text { receive, and problem will be } \\
\text { caught at that time } \\
\text { Discrepancy Item Closed } \\
\text { 4/12/96 }\end{array}$ \\
\hline $\begin{array}{l}\text { 3.1.5.3 Complete TRU } \\
\text { Waste Shipping Data }\end{array}$ & send data update to SWITS & $\begin{array}{l}\text { there are generic update messages } \\
\text { specified in } 3.1 .5 \text { (Shipping), but } \\
\text { there is not specific mention of } \\
\text { needing them for TRU waste }\end{array}$ & $\begin{array}{l}\text { design may not support update for TRU } \\
\text { processing }\end{array}$ & $\begin{array}{l}\text { Comments provided after } \\
\text { review of V\&V } \\
\text { discrepancies: process } \\
3.1 .5 \text { revised to add this } \\
\text { function } \\
\text { Action Completed and } \\
\text { Discrepancy Item Closed } \\
\text { as of } 3 / 6 / 96\end{array}$ \\
\hline
\end{tabular}




\begin{tabular}{|c|c|c|c|c|}
\hline SRS REFERENCE & REQURREMENT & DISCREPANCY & RATIONALE FOR CATEGORY & RESOLUTION \\
\hline $\begin{array}{l}\text { 3.1.5.3.1 Assemble TRU } \\
\text { Waste Containers }\end{array}$ & input user Signature Password & $\begin{array}{l}\text { screens and specifications for } \\
\text { TRU load out drums do not refer } \\
\text { to signature passwords, but part of } \\
\text { TRU screen hierarchy, which has } \\
\text { signature/password on main screen } \\
\text { - should SRS refer to TRUPACT? }\end{array}$ & $\begin{array}{l}\text { need to verify need for signature } \\
\text { password and ensure it is as specified }\end{array}$ & \multirow[t]{2}{*}{$\begin{array}{l}\text { note signature password } \\
\text { review matrix in V\&V } \\
\text { Report Appendix B }\end{array}$} \\
\hline $\begin{array}{l}\text { 3.1.5.3.3 Complete TRU } \\
\text { Waste Shipping Data }\end{array}$ & input user signature password & $\begin{array}{l}\text { only refers to signature/password } \\
\text { entry for TRUPACT loading } \\
\text { activities }\end{array}$ & may not be done for all shipping & \\
\hline $\begin{array}{l}\text { 3.1.5.3.3 Complete TRU } \\
\text { Waste Shipping Data (for } \\
\text { boxes) }\end{array}$ & send data update to SWITS & $\begin{array}{l}\text { specify a generic message but only } \\
\text { for drums - no specific mention of } \\
\text { TRU waste }\end{array}$ & $\begin{array}{l}\text { design may not support this SWITS } \\
\text { update }\end{array}$ & $\begin{array}{l}\text { 2/20/96: Test Proc Review } \\
\text { Meet: TRU to be further } \\
\text { specified during Phase } 2 \\
\text { requirement reviews and } \\
\text { subsequent specification } \\
\text { updates - TRU and } \\
\text { TRU/RWM discrepancies } \\
\text { will be addressed during } \\
\text { those activities }\end{array}$ \\
\hline
\end{tabular}




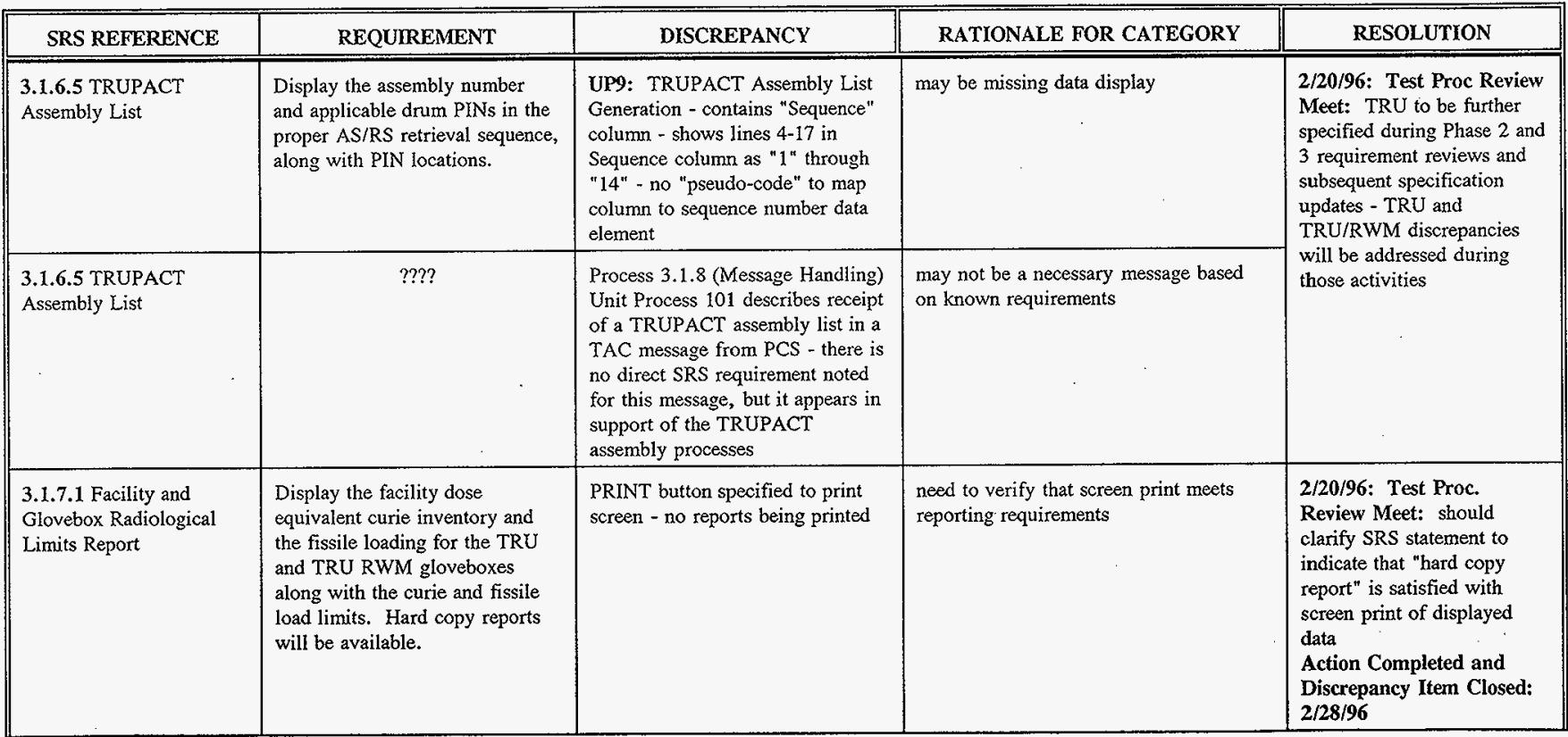




\begin{tabular}{|c|c|c|c|c|}
\hline SRS REFERENCE & REQUIREMENT & DISCREPANCY & RATIONALE FOR CATEGORY & RESOLUTION \\
\hline \multirow[t]{2}{*}{$\begin{array}{l}\text { 3.1.7.3 TRU Glovebox } \\
\text { Fissile Material Inventory } \\
\text { Check } \\
\text { 3.1.7.4 TRU RWM } \\
\text { Glovebox Fissile Material } \\
\text { Inventory Check }\end{array}$} & $\begin{array}{l}\text { Drum PIN and fissile material } \\
\text { inventory from the SIE }\end{array}$ & $\begin{array}{l}\text { no specification for this input- } \\
\text { SIE may be the source for the } \\
\text { screen display, but not clear-UP1 } \\
\text { of Process } 3.1 .3 .3 \text { (TRU Process) } \\
\text { indicates display of } \\
\text { RADMAT_RAD_TOTAL and } \\
\text { RADMAT_UNITS but does not } \\
\text { cite SIE as source } \\
\text { SIE RESS updates NDA and } \\
\text { NDAISO tables }\end{array}$ & $\begin{array}{l}\text { data source and display may not be } \\
\text { meeting requirement }\end{array}$ & \multirow[t]{2}{*}{$\begin{array}{l}\text { 2/20/96: Test Proc Review } \\
\text { Meet: TRU to be further } \\
\text { specified during Phase } 2 \\
\text { requirement reviews and } \\
\text { subsequent specification } \\
\text { updates - TRU and } \\
\text { TRU/RWM discrepancies } \\
\text { will be addressed during } \\
\text { those activities. }\end{array}$} \\
\hline & $\begin{array}{l}\text { Maintain a TRU glovebox fissile } \\
\text { material inventory history }\end{array}$ & not yet specified & $\begin{array}{l}\text { archiving and data retention issues not } \\
\text { yet resolved }\end{array}$ & \\
\hline $\begin{array}{l}\text { 3.1.8.4.1 Sample/ } \\
\text { Container Inventory }\end{array}$ & $\begin{array}{l}\text { receive sample and parent } \\
\text { drum/packet message from PCS }\end{array}$ & $\begin{array}{l}\text { not noted as a Phase } 2 \text { process, } \\
\text { but refers to a Phase } 2 \text { message }\end{array}$ & $\begin{array}{l}\text { process may be using a message that will } \\
\text { not be available when the process is } \\
\text { implemented }\end{array}$ & $\begin{array}{l}\text { Comments provided after } \\
\text { review of V\&V } \\
\text { discrepancies: SDD } \\
\text { updated }-3.1 .8 / U P 49 \text { shows } \\
\text { SPDP as Phase } 2 \\
\text { Action Completed and } \\
\text { Discrepancy Item Closed } \\
\text { as of } 3 / 6 / 96\end{array}$ \\
\hline
\end{tabular}




\begin{tabular}{|c|c|c|c|c|}
\hline SRS REFERENCE & REQUIREMENT & DISCREPANCY & RATIONALE FOR CATEGORY & RESOLUTION \\
\hline $\begin{array}{l}\text { 3.1.8.11 BWAS Message } \\
\text { Pass Through }\end{array}$ & $? ? ? ?$ & $\begin{array}{l}\text { Process } 3.1 .8 \text { (Message Handling) } \\
\text { has a message to receive an assay } \\
\text { abort from the PCS and another } \\
\text { message to pass the abort message } \\
\text { to the BWAS - there is no } \\
\text { mention of such an abort message } \\
\text { pass through in the SRS - these } \\
\text { are Phase } 1 \text { messages }\end{array}$ & may be an addition to scope & $\begin{array}{l}\text { 1/4/96: Test Proc Review } \\
\text { Meet: need to update } \\
3.1 .8 .11 \text { in the SRS for } \\
\text { messages } \\
\text { Action Completed and } \\
\text { Discrepancy Item Closed } \\
\text { as of } 3 / 6 / 96 \text { both directions }\end{array}$ \\
\hline \multirow[t]{2}{*}{$\begin{array}{l}\text { 3.1.9 User Review/ } \\
\text { Modification of WRAP } 1 \\
\text { Waste Processing Data }\end{array}$} & $\begin{array}{l}\text { Update the DMS database and } \\
\text { log the change(s) with the user } \\
\text { ID (signature password), old data } \\
\text { element value(s), date, and time. }\end{array}$ & $\begin{array}{l}\text { UP1-33 screens: affected tables } \\
\text { updated } \\
\text { signature password required to } \\
\text { select Review Complete button } \\
\text { after all screens reviewed }\end{array}$ & $\begin{array}{l}\text { no specification regarding old data } \\
\text { elements or history capture }\end{array}$ & $\begin{array}{l}\text { Comments provided after } \\
\text { review of V\&V } \\
\text { discrepancies: SDD should } \\
\text { be updated to delete } \\
\text { signature password } \\
\text { requirement - journaling } \\
\text { described in SDD } 5.1 \\
\text { Action Completed and } \\
\text { Discrepancy Item Closed } \\
\text { as of } 3 / 6 / 96\end{array}$ \\
\hline & $\begin{array}{l}\text { Select specific "Process Data } \\
\text { Review" screen from "WRAP } 1 \\
\text { DMS Main Menu". }\end{array}$ & $\begin{array}{l}\text { UP33: Display container PINS } \\
\text { for containers receiving } \\
\text { verification exams in WRAP } 1 \\
\text { specifies user select screen } \\
\text { DMSS1231 Verification Data } \\
\text { Review }\end{array}$ & $\begin{array}{l}\text { no such screen in Appendix A - may be } \\
\text { superseded by } 1221\end{array}$ & $\begin{array}{l}\text { Comments provided after } \\
\text { review of V\&V } \\
\text { discrepancies: } 1231 \text { added } \\
\text { to Appendix A } \\
\text { Action Completed and } \\
\text { Discrepancy Item Closed } \\
\text { 3/6/96 }\end{array}$ \\
\hline
\end{tabular}




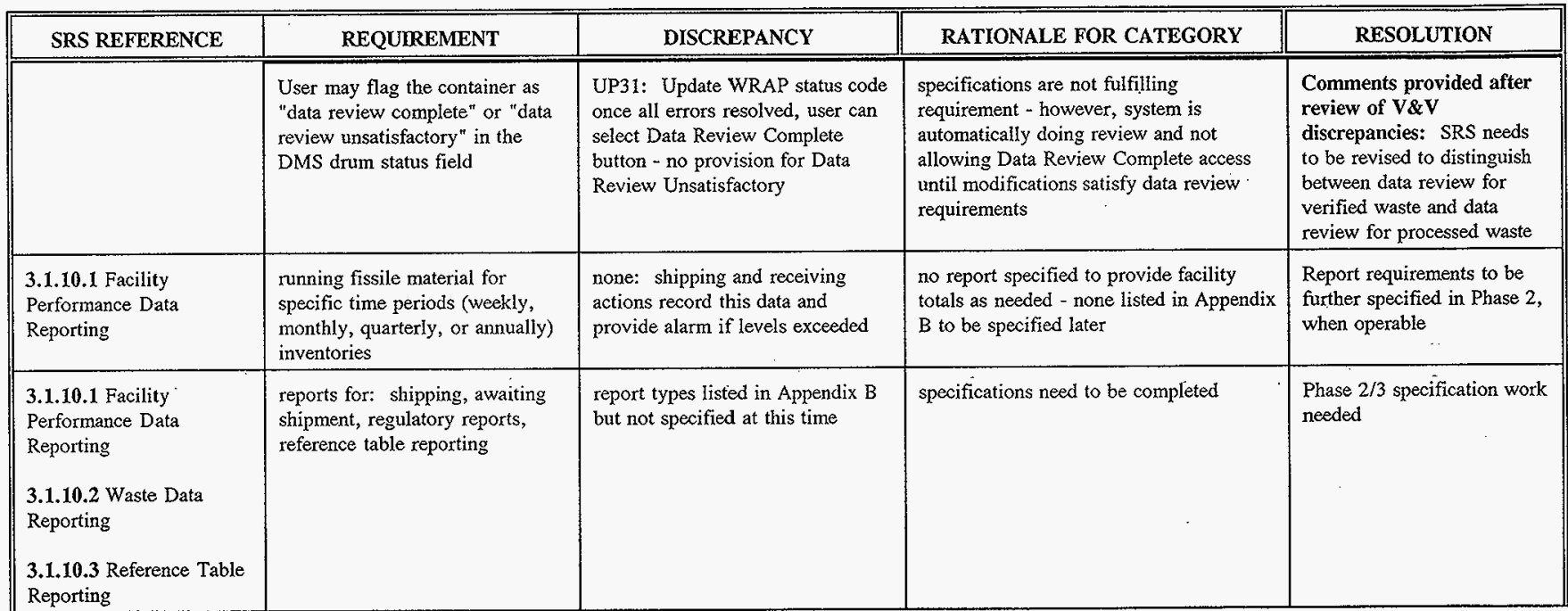




\begin{tabular}{|c|c|c|c|c|}
\hline SRS REFERENCE & REQUREMENT & DISCREPANCY & RATIONALE FOR CATEGORY & RESOLUTION \\
\hline 3.2.1 User Interfaces & $\begin{array}{l}\text { Help screens will be structured } \\
\text { to accommodate a menu driven } \\
\text { system. }\end{array}$ & $\begin{array}{l}\text { 5.1 GENERAL DESIGN } \\
\text { SPECIFICATIONS - } \\
\text { specifies... make use of the } \\
\text { Autohint feature... - no other help } \\
\text { specified in screens or table } \\
\text { structure }\end{array}$ & $\begin{array}{l}\text { heip function does not seem to be as } \\
\text { originally envisioned by SRS }\end{array}$ & $\begin{array}{l}\text { SDD revision establishes } \\
\text { new baseline for Phase 1-- } \\
\text { function operating correctly } \\
\text { as verified in testing. } \\
\text { Discrepancy Item Closed. }\end{array}$ \\
\hline 3.2.3 Software Interfaces & $\begin{array}{l}\text { It is anticipated that SQL calls } \\
\text { to/from the SWITS database will } \\
\text { allow this remote access (to SIE, } \\
\text { PCS, BWAS). }\end{array}$ & $\begin{array}{l}\text { design does not communicate with } \\
\text { BWAS, SIE, and PCS via SWITS } \\
\text { - instead, DMS establishes a } \\
\text { communication capability between } \\
\text { SIE and BWAS via DMS to/from } \\
\text { PCS - DMS deals directly with } \\
\text { SWITS only regarding interaction } \\
\text { between the DMS and SWITS } \\
\text { data bases }\end{array}$ & $\begin{array}{l}\text { see general category } 2 \text { discussion in } \\
\text { V\&V Report Appendix A, paragraph } 2 \text { - } \\
\text { extra scope burden for DMS }\end{array}$ & Need to revise/clarify SRS \\
\hline $\begin{array}{l}\text { 3.2.4 Communications } \\
\text { Interfaces }\end{array}$ & $\begin{array}{l}\text { The DMS will use the HLAN } \\
\text { time to set the DMS system } \\
\text { clock at startup. The DMS will } \\
\text { provide a reference clock service } \\
\text { to the other computers on } \\
\text { WLAN as described in SII } 1994 \text {. }\end{array}$ & $\begin{array}{l}\text { para 3.1.2 Data Sources - Data } \\
\text { sources...include... the HLAN } \\
\text { time clock... - no reference to } \\
\text { providing a "clock service" to } \\
\text { other computers }\end{array}$ & $\begin{array}{l}\text { does not specify processing as originally } \\
\text { envisioned by SRS }\end{array}$ & $\begin{array}{l}\text { Test procedures verify } \\
\text { HLAN clock to set DMS } \\
\text { computer--clock interaction } \\
\text { with other systems to be } \\
\text { determined during Phase } 2\end{array}$ \\
\hline
\end{tabular}




\begin{tabular}{|c|c|c|c|c|}
\hline SRS REFERENCE & REQUIREMENT & DISCREPANCY & RATIONALE FOR CATEGORY & RESOLUTION \\
\hline $\begin{array}{l}\text { 3.3.1 Number of } \\
\text { Terminals to be Supported }\end{array}$ & $\begin{array}{l}\text { The DMS must support } 10 \text { IBM } \\
\text { compatible computers used as } \\
\text { terminals plus } 5 \mathrm{X} \text {-terminals } \\
\text { concurrently. }\end{array}$ & $\begin{array}{l}\text { no SDD discussion of concurrent } \\
\text { operations }\end{array}$ & \multirow[t]{4}{*}{$\begin{array}{l}\text { specifications should indicate factors that } \\
\text { may need to be considered as potential } \\
\text { performance impacts }\end{array}$} & $\begin{array}{l}\text { Implementation of Phase } 1 \\
\text { environment establishes } \\
\text { baseline }\end{array}$ \\
\hline 3.3.3 Printing & $\begin{array}{l}\text { One bar code printer in the } \\
\text { Shipping/Receiving Office } \\
\text { Three facility printers. } \\
\text { One HLAN printer. }\end{array}$ & $\begin{array}{l}\text { no SDD discussion of printer } \\
\text { inventory }\end{array}$ & & Discrepancy Item Closed \\
\hline \multirow[t]{2}{*}{ 3.3.4 Response Times } & $\begin{array}{l}\text { Confirm required data on SWITS } \\
\text { for twenty drums (3.1.1.2.2) in } \\
30 \text { seconds or less with SQL*Net } \\
\text { interface. Includes user request } \\
\text { to confirmation on the DMS } \\
\text { terminal. }\end{array}$ & \multirow[t]{2}{*}{ no specification for response times } & & $\begin{array}{l}\text { Tested via DMS-F91. } \\
\text { Discrepancy Item Closed }\end{array}$ \\
\hline & $\begin{array}{l}\text { Retrieve drum container data } \\
\text { from SWITS for twenty drums } \\
(3.1 .1 .2 .4) \text { and generate DMS } \\
\text { drum container records } \\
\text { (3.1.1.2.5) in three minutes or } \\
\text { less with SQL*Net interface. } \\
\text { Includes user request to } \\
\text { confirmation of DMS database } \\
\text { update. }\end{array}$ & & & $\begin{array}{l}\text { Tested via DMS-F91. } \\
\text { Discrepancy Item Closed }\end{array}$ \\
\hline
\end{tabular}




\begin{tabular}{|c|c|c|c|c|}
\hline SRS REFERENCE & REQUIREMENT & DISCREPANCY & RATIONALE FOR CATEGORY & RESOLUTYON \\
\hline \multirow{4}{*}{. } & $\begin{array}{l}\text { Receive the Pu- } 240 \text { equivalent } \\
\text { value from the PCS, calculate } \\
\text { the Pu-239 FGE, and send the } \\
\text { Pu-239 FGE to the PCS } \\
\text { (3.1.3.3.3) in } 3 \text { seconds or less. }\end{array}$ & & & \multirow{4}{*}{. } \\
\hline & $\begin{array}{l}\text { Display the TRU glovebox fissile } \\
\text { material inventory (3.1.7.3) in } \\
\text { less than } 2 \text { seconds. }\end{array}$ & & & \\
\hline & $\begin{array}{l}\text { Perform a LLW product drum } \\
\text { content inventory update } \\
\text { (3.1.3.1.8) in less than three } \\
\text { seconds. }\end{array}$ & & & \\
\hline & $\begin{array}{l}\text { Perform a data field validity test } \\
\text { in less than one second. }\end{array}$ & & & \\
\hline \multirow[t]{2}{*}{$\begin{array}{l}\text { 3.4.1 Standards } \\
\text { Compliance }\end{array}$} & $\begin{array}{l}\text { The system will be compatible } \\
\text { with the site naming standards } \\
\text { for those items (e.g., buildings) } \\
\text { that have site standard names. }\end{array}$ & $\begin{array}{l}\text { no reference to central site } \\
\text { systems for facilities, persons, } \\
\text { contractors, etc. }\end{array}$ & $\begin{array}{l}\text { PEOPLECORE, FACILITYCORE, and } \\
\text { other central systems are "owners" of } \\
\text { standard data definitions - should at least } \\
\text { reference them and comply with their } \\
\text { data definitions for applicable data }\end{array}$ & \multirow[t]{2}{*}{$\begin{array}{l}\text { To be addressed in next } \\
\text { revision of SRS. Validation } \\
\text { for facility names, etc. is } \\
\text { provided by SWITS- } \\
\text { controlled tables. }\end{array}$} \\
\hline & $\begin{array}{l}\text { The DMS will be designed to } \\
\text { satisfy site production standards. }\end{array}$ & $\begin{array}{l}\text { aside from HLAN, no site } \\
\text { standards for operation specified }\end{array}$ & $\begin{array}{l}\text { should reference production standard } \\
\text { expectations from the development }\end{array}$ & \\
\hline
\end{tabular}




\begin{tabular}{|c|c|c|c|c|}
\hline SRS REFERENCE & REQUIREMENT & DISCREPANCY & RATIONALE FOR CATEGORY & RESOLUTION \\
\hline 3.5.2 Availability & $\begin{array}{l}\text { The DMS operational availability } \\
\text { shall be a minimum of } 99 \% \text { of } \\
\text { scheduled plant operating time } \\
\text { during normal operations as } \\
\text { described in WRAP } 1 \\
\text { Specification Sections } \\
\text { 13461/13462. Normal plant } \\
\text { operation is } 6: 00 \text { AM to } 8: 00 \\
\text { PM on weekdays. }\end{array}$ & $\begin{array}{l}\text { no reference to system availability } \\
\text { - should be specified as a system } \\
\text { parameter }\end{array}$ & $\begin{array}{l}\text { specifications should indicate factors that } \\
\text { may need to be considered as potential } \\
\text { performance impacts }\end{array}$ & $\begin{array}{l}\text { Needs to be addressed in } \\
\text { next revision of SRS }\end{array}$ \\
\hline 3.6.1 Database & $\begin{array}{l}\text { A historical database will be } \\
\text { maintained on the DMS for all } \\
\text { waste containers that have been } \\
\text { shipped from the facility. }\end{array}$ & none & $\begin{array}{l}\text { such an historical database, with the } \\
\text { implications of archiving policies, is not } \\
\text { specified - apparently set aside for phase } \\
2 \text { definition }\end{array}$ & \multirow[t]{2}{*}{$\begin{array}{l}\text { Issue for Phase } 2 \text { or later--to } \\
\text { be addressed during } \\
\text { functional specification } \\
\text { review }\end{array}$} \\
\hline 3.6.2 Operations & $\begin{array}{l}\text { selected operational users can } \\
\text { start and stop DMS without } \\
\text { system administrator required }\end{array}$ & $\begin{array}{l}\text { SDD does not specify how this } \\
\text { will be accomplished }\end{array}$ & $\begin{array}{l}\text { design does not implement any business } \\
\text { rules or rights for this requirement }\end{array}$ & \\
\hline
\end{tabular}




\begin{tabular}{|c|c|c|c|c|}
\hline SRS REFERENCE & REQUIREMENT & DISCREPANCY & RATIONALE FOR CATEGORY & RESOLUTION \\
\hline $\begin{array}{l}\text { 3.6.5.1 General } \\
\text { (scheduling) }\end{array}$ & $\begin{array}{l}\text { Data will be retained on the } \\
\text { system to support year-end } \\
\text { report/processing ( } 15 \text { month } \\
\text { retention). The generation of } \\
\text { these reports will not impact } \\
\text { routine operations. }\end{array}$ & & $\begin{array}{l}\text { such an historical database, with the } \\
\text { implications of archiving policies, is not } \\
\text { specified - apparently set aside for phase } \\
2 \text { definition }\end{array}$ & $\begin{array}{l}\text { Issue for Phase } 2 \text { or later--to } \\
\text { be addressed during } \\
\text { functional specification } \\
\text { review }\end{array}$ \\
\hline 3.6.5.2 Daily (scheduling) & $\begin{array}{l}\text {...the DMS will be available for } \\
\text { extended shift operations when } \\
\text { necessary, except for regularly } \\
\text { scheduled maintenance periods. }\end{array}$ & . & $\begin{array}{l}\text { specifications should indicate factors that } \\
\text { may need to be considered as potential } \\
\text { performance impacts }\end{array}$ & $\begin{array}{l}\text { Needs to be addressed in } \\
\text { next revision of SRS }\end{array}$ \\
\hline $\begin{array}{l}\text { 3.6.6 Reliability and } \\
\text { Recovery }\end{array}$ & $\begin{array}{l}\text { system will maintain a } \\
\text { transaction log and system } \\
\text { administrator will do periodic } \\
\text { system backups }\end{array}$ & $\begin{array}{l}\text { SDD has no specific mention of } \\
\text { transaction log, but presumed to } \\
\text { be a feature of the ORACLE } \\
\text { software - unclear how system } \\
\text { administrator can interact with the } \\
\log \text { for recovery }\end{array}$ & $\begin{array}{l}\text { SA may not have tools to accomplish } \\
\text { necessary recovery }\end{array}$ & $\begin{array}{l}\text { 1/18/96: Test Proc Review } \\
\text { Meet: no resolution } \\
\text { during Phase } 1 \text { - the tools } \\
\text { for this function have yet to } \\
\text { be determined - this is } \\
\text { pending defnition of the } \\
\text { procedures associated with } \\
\text { the system administration } \\
\text { function, which then impact } \\
\text { the SA tool design. Issue } \\
\text { for Phase } 2 \text { or later }\end{array}$ \\
\hline
\end{tabular}




\begin{tabular}{|c|c|c|c|c|}
\hline SRS REFERENCE & REQUIREMENT & DISCREPANCY & RATIONALE FOR CATEGORY & RESOLUTYON \\
\hline \multirow[t]{3}{*}{ 3.6.7 Audit } & $\begin{array}{l}\text { It is anticipated audited data } \\
\text { fields will not exceed five } \\
\text { percent of the data elements in } \\
\text { the database. }\end{array}$ & $\begin{array}{l}\text { no limit noted - unclear how } \\
\text { system administrator interacts with } \\
\text { journal }\end{array}$ & \multirow[t]{2}{*}{$\begin{array}{l}\text { capabilities and expectations for system } \\
\text { administration can affect level of detail } \\
\text { for this portion of the development }\end{array}$} & \multirow{2}{*}{$\begin{array}{l}\text { 1/30/96: Test Proc Review } \\
\text { Meet: SRS should be } \\
\text { updated for all of audit } \\
\text { requirement - explain SA } \\
\text { interaction by table rather } \\
\text { than by data element - } \\
\text { remove reference to } 5 \% \text {. } \\
\text { Needs to be addressed in } \\
\text { next revision of SRS }\end{array}$} \\
\hline & $\begin{array}{l}\text { It shall be possible for the data } \\
\text { administrator to turn the audit } \\
\text { trail on or off and to change the } \\
\text { selection of data fields audited. }\end{array}$ & $\begin{array}{l}\text { unclear how system administrator } \\
\text { interacts with journal }\end{array}$ & & \\
\hline & $\begin{array}{l}\text { The audit trail shall maintain a } \\
\text { record of the data, time, } \\
\text { previous value (for data } \\
\text { changes), current value, and the } \\
\text { identity of the person entering } \\
\text { the data (identified through the } \\
\text { signature password). }\end{array}$ & $\begin{array}{l}\text { para 5.1: audit trail of database } \\
\text { changes implemented through use } \\
\text { of journal feature - no description } \\
\text { of audit data captured }\end{array}$ & $\begin{array}{l}\text { need to clarify that journal feature has } \\
\text { necessary information to support audit }\end{array}$ & $\begin{array}{l}\text { 1/30/96: Test Proc Review } \\
\text { Meet: change SRS to } \\
\text { update requirement for data } \\
\text { and log on passwords }\end{array}$ \\
\hline
\end{tabular}




\begin{tabular}{|c|c|c|c|c|}
\hline SRS REFERENCE & REQUTREMENT & DISCREPANCY & RATIONALE FOR CATEGORY & RESOLUTION \\
\hline \multirow[t]{3}{*}{$\begin{array}{l}\text { 3.6.13 Security and } \\
\text { Privacy }\end{array}$} & $\begin{array}{l}\text { network administrator perform } \\
\text { network monitoring and network } \\
\text { configuration changes }\end{array}$ & $\begin{array}{l}\text { SDD has no provision for network } \\
\text { administration - may be deferred } \\
\text { to site network operations - } \\
\text { however, WLAN and node- } \\
\text { specific oversight not provided }\end{array}$ & $\begin{array}{l}\text { may not have appropriate network } \\
\text { maintenance functions covered }\end{array}$ & $\begin{array}{l}\text { 1/18/96: Test Proc Review } \\
\text { Meet: no resolution } \\
\text { during Phase } 1 \text { - definition } \\
\text { of responsibilities between } \\
\text { WRAP network } \\
\text { administration and the } \\
\text { HLAN network } \\
\text { administration is not } \\
\text { available }\end{array}$ \\
\hline & \multirow[t]{2}{*}{$\begin{array}{l}\text { A WRAP I operations manager } \\
\text { will have the authority to add, } \\
\text { change, or delete user access to } \\
\text { the DMS. Once the manager has } \\
\text { approved the changes, the system } \\
\text { administrator will be empowered } \\
\text { to make the necessary changes. }\end{array}$} & $\begin{array}{l}\text { SDD has no discussion of } \\
\text { Operations Manager interaction - a } \\
\text { procedural function rather than a } \\
\text { system one? }\end{array}$ & $\begin{array}{l}\text { need to ensure procedural/system } \\
\text { functions are synchronized }\end{array}$ & $\begin{array}{l}\text { 1/30/96: Test Proc Review } \\
\text { Meet: deferred to } \\
\text { procedural documentation } \\
\text { when prepared }\end{array}$ \\
\hline & & $\begin{array}{l}\text { para 5.1.4: system administrator } \\
\text { responsible for maintenance of the } \\
\text { software system, communications, } \\
\text { and hardware - description in this } \\
\text { SDD paragraph seems to imply a } \\
\text { technical role rather than an } \\
\text { administrative one }\end{array}$ & $\begin{array}{l}\text { role of system administrator needs to be } \\
\text { clarified - can affect final design to } \\
\text { support this function }\end{array}$ & $\begin{array}{l}\text { 1/30/96: Test Proc Review } \\
\text { Meet: SRS needs to be } \\
\text { updated - SDD impacts } \\
\text { should then be assessed and } \\
\text { specifications clarified }\end{array}$ \\
\hline
\end{tabular}




\begin{tabular}{|l|l|l||c|}
\hline SRS REFERENCE & \multicolumn{1}{|c|}{ REQUIREMENT } & \multicolumn{1}{|c|}{ DISCREPANCY } & RATIONALE FOR CATEGORY \\
\hline \hline & $\begin{array}{l}\text { There are three privileged users } \\
\text { on the system: the system, } \\
\text { database, and network } \\
\text { administrators. }\end{array}$ & $\begin{array}{l}\text { para 4.3.3: data/database } \\
\text { administrator with authority to } \\
\text { update the database structure, } \\
\text { perform global data manipulation, } \\
\text { maintain the data dictionary - } \\
\text { described as a "developer } \\
\text { interface" }\end{array}$ & \\
\hline & $\begin{array}{l}\text { para 5.1.4: system administrator } \\
\text { responsible for maintenance of the } \\
\text { software system, communications, } \\
\text { and hardware - no provision in the } \\
\text { SDD for a network administrator }\end{array}$ & \\
\hline
\end{tabular}




\begin{tabular}{|c|c|c|c|c|}
\hline SRS REFERENCE & REQUIREMENT & DISCREPANCY & RATIONALE FOR CATEGORY & RESOLUTION \\
\hline \multicolumn{5}{|c|}{ CATEGORY 3 DISCREPANCIES } \\
\hline $\begin{array}{l}2.4 \text { GENERAL } \\
\text { CONSTRAINTS }\end{array}$ & $\begin{array}{l}\text { Approval Designator. The } \\
\text { DMS has been assigned a } \\
\text { Approval Designator Q. In } \\
\text { accordance with this assessment, } \\
\text { the software development project } \\
\text { must adhere to the requirements } \\
\text { identified in WHC-CM-4-2, } \\
\text { Quality Assurance Manual, QR } \\
19.0 \text {, WHC-CM-6-1, Standard } \\
\text { Engineering Practices, EP-2.1, } \\
\text { and WHC-CM-3-10, Software } \\
\text { Practices. }\end{array}$ & $\begin{array}{l}1.0 \text { INTRODUCTION or } \\
\text { elsewhere: WHC-CM-6-1 not } \\
\text { cited or referenced }\end{array}$ & should be included for completeness & $\begin{array}{l}\text { Needs to be addressed in } \\
\text { mext revision of SRS }\end{array}$ \\
\hline $\begin{array}{l}\text { 3.1.1.1 Print Bar Code } \\
\text { Package ID Labels }\end{array}$ & $\begin{array}{l}\text { not shown as selection in SDD } \\
\text { para } 5.2 .1\end{array}$ & $\begin{array}{l}\text { screen navigation description not } \\
\text { correct }\end{array}$ & $\begin{array}{l}\text { typo or error in SDD document as } \\
\text { written - document needs to be clarified }\end{array}$ & $\begin{array}{l}\text { Needs to be incorporated } \\
\text { into system/next revision of } \\
\text { SDD }\end{array}$ \\
\hline
\end{tabular}




\begin{tabular}{|c|c|c|c|c|}
\hline SRS REFERENCE & REQUIREMENT & DISCREPANCY & RATIONALE FOR CATEGORY & RESOLUTION \\
\hline \multirow[t]{2}{*}{$\begin{array}{l}\text { 3.1.2.2 Drum or Box } \\
\text { Container NDA Data } \\
\text { Operation }\end{array}$} & $\begin{array}{l}\text { send drum characterization \& } \\
\text { isotopic quantity data to SIE }\end{array}$ & $\begin{array}{l}\text { Appendix F } 3.1 .2 .2 / \mathrm{UP} 3 \text { only } \\
\text { specifies this message flow for } \\
\text { REVISIT occurrences }\end{array}$ & need to clarify Appendix F spec & $\begin{array}{l}\text { Needs to be addressed in } \\
\text { next revision of SRS }\end{array}$ \\
\hline & $\begin{array}{l}\text { Using the waste drum or box } \\
\text { container PIN as the primary } \\
\text { key, retrieve and transfer the } \\
\text { data (characterization and } \\
\text { quantitative) needed by the SIE } \\
\text { or BWAS for its assay data } \\
\text { revisit include the purpose of the } \\
\text { assay, i.e. REVISIT }\end{array}$ & $\begin{array}{l}\text { UP3: NDA Revisit - specifies } \\
\text { send message to SIE - no mention } \\
\text { of BWAS }\end{array}$ & $\begin{array}{l}\text { typo or error in SDD document as } \\
\text { written - document needs to be clarified - } \\
\text { probable Phase } 2 \text { update }\end{array}$ & $\begin{array}{l}\text { Comments provided after } \\
\text { review of V\&V } \\
\text { discrepancies: BWAS } \\
\text { messages to be implemented } \\
\text { in Phase } 2\end{array}$ \\
\hline $\begin{array}{l}\text { 3.1.3.2.1 LLW RWM } \\
\text { Separate Compliant from } \\
\text { Non-Compliant }\end{array}$ & receive packet PINs from PCS & $\begin{array}{l}\text { (Redundant with } 3.1 .3 .1 .4 ? \text { ) } \\
\text { Phase } 2 \text { messages also, described } \\
\text { only in context of transfer stand } \\
\text { add/remove }\end{array}$ & $\begin{array}{l}\text { typo or error in SDD document as } \\
\text { written - document needs to be clarified }\end{array}$ & $\begin{array}{l}\text { Comments provided after } \\
\text { review of V\&V } \\
\text { discrepancies: } 3.1 .3 .1 .4 \text { is } \\
\text { at } L L W \text { Glovebox with } \\
3.1 .3 .2 .1 \text { is at LLW RWM } \\
\text { Glovebox - no change } \\
\text { required }\end{array}$ \\
\hline $\begin{array}{l}\text { 3.1.3.2.6 Perform Waste } \\
\text { Treatment }\end{array}$ & $\begin{array}{l}\text { User requests the "LLW RWM } \\
\text { Treatment" screen from the } \\
\text { "Process Operations - LLW } \\
\text { RWM Process Glovebox" menu. }\end{array}$ & $\begin{array}{l}\text { UP14: Items are treated and } \\
\text { waste records populated - specifies } \\
\text { selection of DMSS0326 LLW } \\
\text { RWM TREATMENT screen from } \\
\text { DMSS0324 LLW RWM } \\
\text { Treatment Item Assembly }\end{array}$ & $\begin{array}{l}\text { screen hierarchy different than } \\
\text { envisioned in SRS - SRS should probably } \\
\text { be updated }\end{array}$ & $\begin{array}{l}\text { Needs to be addressed in } \\
\text { next revision of SRS }\end{array}$ \\
\hline
\end{tabular}




\begin{tabular}{|c|c|c|c|c|}
\hline SRS REFERENCE & REQUIREMENT & DISCREPANCY & RATIONALE FOR CATEGORY & RESOLUTION \\
\hline & $\begin{array}{l}\text { User input of worksheet number } \\
\text { from list of available worksheets. }\end{array}$ & $\begin{array}{l}\text { UP13: All items to be treated } \\
\text { (packets and samples) are on } \\
\text { treatment table - specifies user } \\
\text { entry of Worksheet ID - parent } \\
\text { menu (0324) has a pop-up LOV to } \\
\text { WORKSHEET table }\end{array}$ & $\begin{array}{l}\text { LOV use is not available at this stage - } \\
\text { Worksheet ID seems to carry down to } \\
\text { this menu - Appendix F should be } \\
\text { clarified }\end{array}$ & $\begin{array}{l}\text { Revised update of "as-built" } \\
\text { SDD. Discrepancy Item } \\
\text { Closed }\end{array}$ \\
\hline $\begin{array}{l}\text { 3.1.3.3 TRU Process } \\
\text { Glovebox }\end{array}$ & $\begin{array}{l}\text { The user selects "TRU Process } \\
\text { Glovebox" from the "Glovebox } \\
\text { Operations" screen. }\end{array}$ & $\begin{array}{l}\text { UP1: TRU glovebox dnim status } \\
\text { at entry specifies user select } \\
\text { DMSS0331 TRU Entry from TRU } \\
\text { Glovebox Menu - no "Glovebox } \\
\text { Operations" menu specified in } \\
\text { SDD - TRU Glovebox menu has } \\
\text { selections including TRU Entry }\end{array}$ & $\begin{array}{l}\text { need to update screen hierarchy } \\
\text { discussion in SRS }\end{array}$ & $\begin{array}{l}\text { Needs to be addressed in } \\
\text { next revision of SRS }\end{array}$ \\
\hline $\begin{array}{l}\text { 3.1.3.3.3 TRU Sorting } \\
\text { Glovebox Non-compliant } \\
\text { Waste Loadout }\end{array}$ & $\begin{array}{l}\mathrm{Pu}-240 \text { value (and uncertainty) } \\
\text { from the PCS. }\end{array}$ & $\begin{array}{l}\text { UP5: TRU Non-Compliant } \\
\text { Packet displays FGE - indicates } \\
\text { relation to messages NCIP, NCIT } \\
\text { - PU-240 data passed in PCSDMS } \\
\text { message PAMR specified in } \\
3.1 .8 / \text { UP45 - not mentioned in } \\
\text { this UP }\end{array}$ & $\begin{array}{l}\text { specifications need to cite PAMR } \\
\text { message as source of data and } \\
\text { computation }\end{array}$ & $\begin{array}{l}\text { To be addressed during } \\
\text { Phase } 2 / 3 \text { functional } \\
\text { specification reviews }\end{array}$ \\
\hline
\end{tabular}




\begin{tabular}{|c|c|c|c|c|}
\hline SRS REFERENCE & REQUIREMENT & DISCREPANCY & RATIONALE FOR CATEGORY & RESOLUTION \\
\hline & $\begin{array}{l}\text { The DMS will utilize the Pu- } 240 \\
\text { value to calculate the Pu- } 239 \\
\text { FGE of the waste packet and } \\
\text { display this value on the TRU } \\
\text { Process Glovebox DMS } \\
\text { terminal. This value will be } \\
\text { retained in a temporary file } \\
\text { (available for review by the } \\
\text { Sorting glovebox user) until it is } \\
\text { determined whether or not the } \\
\text { packet is compliant or non- } \\
\text { compliant. }\end{array}$ & $\begin{array}{l}\text { UP5: TRU Non-Compliant } \\
\text { Packet display only - requirement } \\
\text { for "temporary storage" is not } \\
\text { addressed }\end{array}$ & $\begin{array}{l}\text { questionable that this should be stated in } \\
\text { SRS - the storage and display of data } \\
\text { seems to meet the processing } \\
\text { requirements, and is done through the } \\
\text { technical implementation of the } \\
\text { requirements by the developer }\end{array}$ & . \\
\hline $\begin{array}{l}\text { 3.1.3.3.5 Empty Feed } \\
\text { Drum Compaction }\end{array}$ & none & $\begin{array}{l}\text { 3.1.8/UP97 shows message EDPR } \\
\text { - no specific SRS requirement } \\
\text { noted - related to UP } 7\end{array}$ & $\begin{array}{l}\text { need to update SRS description of } \\
\text { message requirement for empty drums }\end{array}$ & $\begin{array}{l}\text { Comments provided after } \\
\text { review of V\&V } \\
\text { discrepancies: empty drum } \\
\text { process route message added } \\
\text { to SRS } 3.1 .8 \\
\text { Action Completed and } \\
\text { Diserepancy Item Closed } \\
\text { as of } 3 / 6 / 96\end{array}$ \\
\hline $\begin{array}{l}\text { 3.1.4.1 Obtain Waste } \\
\text { Sample \& Initiate Chain } \\
\text { of Custody }\end{array}$ & $\begin{array}{l}\text { receive sample bottle ID and } \\
\text { parent drum or packet PIN from } \\
\text { PCS }\end{array}$ & $\begin{array}{l}\text { indicates receipt of message - } \\
\text { chain of custody starts in Unit } \\
\text { Process } 4\end{array}$ & $\begin{array}{l}\text { typo or error in SDD document as } \\
\text { written - document needs to be clarified }\end{array}$ & $\begin{array}{l}\text { Needs to be incorporated } \\
\text { into system/next SDD }\end{array}$ \\
\hline
\end{tabular}




\begin{tabular}{|c|c|c|c|c|}
\hline SRS REFERENCE & REQUIREMENT & DISCREPANCY & RATIONALE FOR CATEGORY & RESOLUTION \\
\hline $\begin{array}{l}\text { 3.1.4.5 Treatment } \\
\text { Worksheet Entry }\end{array}$ & $\begin{array}{l}\text { Store each Worksheet record } \\
\text { entered. }\end{array}$ & $\begin{array}{l}\text { SRS paragraph numbering not } \\
\text { correct }\end{array}$ & need to fix typo in SRS & $\begin{array}{l}\text { Needs to be addressed in } \\
\text { next revision of SRS }\end{array}$ \\
\hline \multirow[t]{2}{*}{$\begin{array}{l}\text { 3.1.5.1 Generate Drum or } \\
\text { Box Documentation }\end{array}$} & $\begin{array}{l}\text { Manually entered data to } \\
\text { complete shipping forms }\end{array}$ & $\begin{array}{l}\text { UP2: Update the Onsite } \\
\text { Radioactive Shipment Record - } \\
\text { specifies displays of all } \\
\text { information for form, with } \\
\text { lookups to tables - user entry } \\
\text { specified only for Special Nuclear } \\
\text { Material ( } X \text { or } N \text { ), To } \\
\text { Building/Area, From } \\
\text { Building/Area columns }\end{array}$ & $\begin{array}{l}\text { SRS is not specific on data to be entered } \\
\text { and/or displayed only - specifications } \\
\text { may need a final verification to ensure } \\
\text { all necessary data entry can be } \\
\text { accomplished }\end{array}$ & $\begin{array}{l}\text { Needs to be addressed in } \\
\text { next revision of SRS }\end{array}$ \\
\hline & $\begin{array}{l}\text { Generated list for drum or box } \\
\text { shipment based on drum type } \\
\text { (secondary waste type code) }\end{array}$ & $\begin{array}{l}\text { UPL: Selection of WRAP } \\
\text { shipment form to be completed } \\
\text { - generates Container PINs in } \\
\text { shipment - no reference to } \\
\text { SWTYP_GROUP }\end{array}$ & $\begin{array}{l}\text { screen content and hierarchy seem out of } \\
\text { sync with requirements }\end{array}$ & $\begin{array}{l}\text { Will be part of Phase } 2 / 3 \\
\text { functional reviews and } \\
\text { subsequent SDD update }\end{array}$ \\
\hline
\end{tabular}




\begin{tabular}{|c|c|c|c|c|}
\hline SRS REFERENCE & REQUTREMENT & DISCREPANCY & RATIONALE FOR CATEGORY & RESOLUTION \\
\hline $\begin{array}{l}\text { 3.1.5.2.1 Requesting } \\
\text { Retrieval of Drums for } \\
\text { Shipment and } \\
\text { 3.1.5.1 Generate Drum or } \\
\text { Box Documentation }\end{array}$ & $\begin{array}{l}\text { Upload the pick list to the PCS } \\
\text { and } \\
\text { User request for pick list } \\
\text { download to the PCS. }\end{array}$ & $\begin{array}{l}\text { UP9: Display of waste containers } \\
\text { for shipping user selects Send } \\
\text { Shipment Pick List to PCS button } \\
\text { - generates TSPL and LSPL } \\
\text { messages if } \\
\text { RDET SWTYP_GROUP equals } \\
\text { either TRU or LLW }\end{array}$ & $\begin{array}{l}\text { both requirements specify same action - } \\
\text { appears consolidated in SDD - may be } \\
\text { redundant requirements in SRS }\end{array}$ & $\begin{array}{l}\text { Comments provided after } \\
\text { review of V\&V } \\
\text { discrepancies: SRS updated } \\
\text { to delete PCS upload } \\
\text { requirement } \\
\text { Action Completed and } \\
\text { Discrepancy Item Closed } \\
\text { as of } 3 / 6 / 96\end{array}$ \\
\hline \multirow[t]{3}{*}{$\begin{array}{l}\text { 3.1.5.2.2 Certification } \\
\text { Data to SWITS }\end{array}$} & $\begin{array}{l}\text { send certification and location } \\
\text { confirmation messages to SWITS }\end{array}$ & $\begin{array}{l}\text { only mentions work for drums, } \\
\text { none for boxes }\end{array}$ & $\begin{array}{l}\text { typo or error in document as written - } \\
\text { document needs to be clarified }\end{array}$ & \multirow{2}{*}{$\begin{array}{l}\text { SRS updated } \\
\text { Action Completed and } \\
\text { Discrepancy Item Closed: } \\
3 / 6 / 96\end{array}$} \\
\hline & $\begin{array}{l}\text { Display the message on the } \\
\text { "Loading Dock Container } \\
\text { Shipping" screen for the } \\
\text { Shipping/Receiving terminal. }\end{array}$ & note: two paragraph "A" in SRS & $\begin{array}{l}\text { typo in SRS document as written - } \\
\text { document needs to be updated }\end{array}$ & \\
\hline & $\begin{array}{l}\text { Appendix F UP11: DMS to } \\
\text { transmit applicable SWITS data } \\
\text { to SWITS for all drums sent to } \\
\text { the Processing Area in WRAP } \\
\text { Appendix F UP12: DMS to } \\
\text { transmit all applicable SWITS } \\
\text { data to SWITS for all drums } \\
\text { received by WRAP }\end{array}$ & $\begin{array}{l}\text { wording of Unit Process titles in } \\
\text { specifications seems to be oriented } \\
\text { toward receiving rather than } \\
\text { shipping }\end{array}$ & $\begin{array}{l}\text { text copy from other part of the SDD } \\
\text { and not edited? }\end{array}$ & $\begin{array}{l}\text { Needs to be addressed in } \\
\text { next revision of SRS }\end{array}$ \\
\hline
\end{tabular}




\begin{tabular}{|c|c|c|c|c|}
\hline SRS REFERENCE & REQUIREMENT & DISCREPANCY & RATIONALE FOR CATEGORY & RESOLUTION \\
\hline $\begin{array}{l}\text { 3.1.5.3.1 Assemble TRU } \\
\text { Waste Containers }\end{array}$ & $\begin{array}{l}\text { User request for the "TRUPACT } \\
\text { Payload Assembly" screen from } \\
\text { the "Shipping" screen. }\end{array}$ & $\begin{array}{l}\text { UP16: Display of data in support } \\
\text { of TRUPACT II loading } \\
\text { operations specifies user selection } \\
\text { of DMSS0603, TRUPACT Cask } \\
\text { Loading/Certification }\end{array}$ & $\begin{array}{l}\text { specifications do not flag this operation } \\
\text { as Phase } 2 \text { or } 3 \text {, although SDD } \\
\text { paragraph } 2.1 .1 \text { indicates it is not Phase } \\
1-S D D \text { should be reviewed for possible } \\
\text { update in Appendix F to indicate } \\
\text { appropriate phase }\end{array}$ & $\begin{array}{l}\text { Needs to be addressed in } \\
\text { next revision of SRS. } \\
\text { Needs to be incorporated } \\
\text { into system/next SDD. } \\
\text { Issue for Phase } 2 \text { or later }\end{array}$ \\
\hline $\begin{array}{l}\text { 3.1.5.3.2 Load the TRU } \\
\text { Waste Assemblies into } \\
\text { Casks }\end{array}$ & $\begin{array}{l}\text { Confirmation of entered data and } \\
\text { update of the DMS database. }\end{array}$ & $\begin{array}{l}\text { UP16: Display of data in support } \\
\text { of TRUPACT II loading } \\
\text { operations - not specified, but may } \\
\text { be a presumed result of displaying } \\
\text { data on the screen as it is entered } \\
\text { - no feedback to user indicating } \\
\text { data posted to data base }\end{array}$ & $\begin{array}{l}\text { SRS need for user feedback may be too } \\
\text { strongly stated }\end{array}$ & $\begin{array}{l}\text { Statement needs to be } \\
\text { moved to be a general } \\
\text { requirement--confirmation of } \\
\text { commit/changes is } \\
\text { appropriate }\end{array}$ \\
\hline $\begin{array}{l}\text { 3.1.5.3.3 Complete TRU } \\
\text { Waste Shipping Data }\end{array}$ & all & $\begin{array}{l}\text { entire requirement seems to be } \\
\text { very redundant with } 3.1 .5 .3 .2\end{array}$ & $\begin{array}{l}\text { should consider consolidating } \\
\text { requirements and resultant design }\end{array}$ & $\begin{array}{l}\text { Needs to be addressed in } \\
\text { next revision of SRS. Issue } \\
\text { for Phase } 2 \text { or later }\end{array}$ \\
\hline
\end{tabular}




\begin{tabular}{|c|c|c|c|c|}
\hline SRS REFERENCE & REQUREMENT & DISCREPANCY & RATIONALE FOR CATEGORY & RESOLUTION \\
\hline \multirow[t]{2}{*}{$\begin{array}{l}\text { 3.1.6.3 AS/RS Retrieval } \\
\text { \& Storage via Transfer } \\
\text { Car }\end{array}$} & $\begin{array}{l}\text { Request "AS/RS Storage Pick } \\
\text { List" screen from the "Pick List } \\
\text { Menu." }\end{array}$ & $\begin{array}{l}\text { UP5: AS/RS Retrieval \& Storage } \\
\text { via Transfer Car - states "Request } \\
\text { screen (DMSS0903) from Pick } \\
\text { List Menu" - no specification in } \\
\text { this process for the Pick List } \\
\text { Menu itself }\end{array}$ & $\begin{array}{l}\text { need to include specifications in SDD for } \\
\text { generation of basic menus }\end{array}$ & \multirow[t]{3}{*}{$\begin{array}{l}\text { Addressed during SDD "as- } \\
\text { built" update. Discrepancy } \\
\text { Item Closed }\end{array}$} \\
\hline & $\begin{array}{l}\text { Transfer the selected drum PIN } \\
\text { to the AS/RS Transfer Car Pick } \\
\text { List }\end{array}$ & $\begin{array}{l}\text { UP5 has no mention of PIN } \\
\text { transfer - this transfer seems to } \\
\text { occur in UP7 which transfers } \\
\text { PINs across bins marked either as } \\
\text { Ready for Shipment or Shipment }\end{array}$ & \multirow[t]{2}{*}{$\begin{array}{l}\text { seems to be a mismatch between } \\
\text { processing, as specified in the SRS, and } \\
\text { the work being supported }\end{array}$} & \\
\hline $\begin{array}{l}\text { 3.1.6.4 AS/RS Shipping } \\
\text { Pick List }\end{array}$ & $\begin{array}{l}\text { User selection of drums for entry } \\
\text { on the pick list }\end{array}$ & $\begin{array}{l}\text { UP7 indicates drum PKG_ID only } \\
\text { in relation to bins - UP5 actually } \\
\text { seems to deal with individual } \\
\text { drums as described by this } \\
\text { requirement }\end{array}$ & & \\
\hline
\end{tabular}




\begin{tabular}{|c|c|c|c|c|}
\hline SRS REFERENCE & REQUIREMENT & DISCREPANCY & RATIONALE FOR CATEGORY & RESOLUTION \\
\hline \multirow[t]{2}{*}{$\begin{array}{l}\text { 3.1.6.5 TRUPACT } \\
\text { Assembly List }\end{array}$} & $\begin{array}{l}\text { User request to send TRUPACT } \\
\text { assembly pick list to AS/RS. }\end{array}$ & $\begin{array}{l}\text { UP9: TRUPACT Assembly List } \\
\text { Generation - "Commit" button } \\
\text { creates records and saves data - } \\
\text { then "Transmit" button sends } \\
\text { location "AS/RS" to PCS - }\end{array}$ & $\begin{array}{l}\text { perhaps poorly worded in SRS - not } \\
\text { clear why message would be sent "to } \\
\text { AS/RS" }\end{array}$ & $\begin{array}{l}\text { Comments provided after } \\
\text { review of V\&V } \\
\text { discrepancies: SRS } \\
\text { updated to send message to } \\
\text { PCS. "Transmit button } \\
\text { sends list only if location for } \\
\text { all drums is currently } \\
\text { AS/RS } \\
\text { Action Completed and } \\
\text { Discrepancy Item Closed } \\
\text { as of } 3 / 6 / 96\end{array}$ \\
\hline & $\begin{array}{l}\text { User entry of TRUPACT } \\
\text { assembly data including shipment } \\
\text { number, assembly ID, and list of } \\
\text { PINs by loading sequence. }\end{array}$ & $\begin{array}{l}\text { UP9: TRUPACT Assembly List } \\
\text { Generation - specifies all are } \\
\text { manually entered or off a "pop } \\
\text { up" screen }\end{array}$ & extra scope? & $\begin{array}{l}\text { Comments provided after } \\
\text { review of V\&V } \\
\text { discrepancies: scope is } \\
\text { appropriate } \\
\text { Action Completed and } \\
\text { Discrepancy Item Closed } \\
\text { as of } 3 / 6 / 96\end{array}$ \\
\hline
\end{tabular}




\begin{tabular}{|c|c|c|c|c|}
\hline SRS REFERENCE & REQUIREMENT & DISCREPANCX & RATIONALE FOR CATEGORY & RESOLUTION \\
\hline $\begin{array}{l}\text { 3.1.7.3 TRU Glovebox } \\
\text { Fissile Material Inventory } \\
\text { Check }\end{array}$ & $\begin{array}{l}\text { Transfer drum PIN with previous } \\
\text { location of TRU glovebox } \\
\text { transfer drum port and a new } \\
\text { location other than the TRU } \\
\text { Glovebox RWM Transfer Port. }\end{array}$ & $\begin{array}{l}\text { UP2: Container Locations and } \\
\text { Relationships - locations entered } \\
\text { by user - specifies "From PIN" } \\
\text { and "To PIN" display as part of } \\
\text { "Container Relationships" -actual } \\
\text { location codes entered are } \\
\text { presumed to be based on business } \\
\text { rules for this process (i.e., TRU- } \\
\text { related locations are not specified) }\end{array}$ & $\begin{array}{l}\text { SRS should refer to business nules } \\
\text { regarding codes needed for this } \\
\text { requirement - should be specified as } \\
\text { "manual" (i.e. not intemal to system) } \\
\text { process }\end{array}$ & $\begin{array}{l}\text { To be addressed in next } \\
\text { update of SRS after Phase } \\
2 / 3 \text { functional specification } \\
\text { reviews }\end{array}$ \\
\hline \multirow[t]{2}{*}{$\begin{array}{l}\text { 3.1.8.1 Drum or Box } \\
\text { Inventory or if at LLW } \\
\text { Entry Glovebox Lift table } \\
\text { and drum not overpacked }\end{array}$} & $\begin{array}{l}\text { if AGB at PAN, always send } \\
\text { download data message } \\
\text { instructing SIE to transmit drum } \\
\text { database to specific PAN or } \\
\text { GEA also, send location message } \\
\text { with overpack drum PIN to PCS } \\
\text { also, send location message with } \\
\text { drum PIN to PCS }\end{array}$ & $\begin{array}{l}\text { 3.1.8 message sent when location } \\
=\text { BDCVYR_" } x ", \text { N_NCRSL, } \\
\text { AIRCVYR_." }{ }^{\prime \prime} \text { INFDCVYR }\end{array}$ & $\begin{array}{l}\text { typo or error in SRS or SDD document } \\
\text { as written - document needs to be } \\
\text { clarified }\end{array}$ & \multirow[t]{2}{*}{$\begin{array}{l}\text { To be addressed in next } \\
\text { revision of SRS }\end{array}$} \\
\hline & $\begin{array}{l}\text { send location message with } \\
\text { overpack drum PIN to PCS }\end{array}$ & $\begin{array}{l}\text { requirement is for message if at } \\
\text { LLW Entry Glovebox Lift table - } \\
\text { 3.1.8/UP9-10 refer to CL when } \\
\text { drum at LLW Entry Glovebox } \\
\text { Port }\end{array}$ & $\begin{array}{l}\text { should fix message occasion naming } \\
\text { convention to ensure clarity }\end{array}$ & \\
\hline
\end{tabular}




\begin{tabular}{|c|c|c|c|c|}
\hline SRS REFERENCE & REQUIREMENT & DISCREPANCY & RATIONALE FOR CATEGORY & RESOLUTION \\
\hline $\begin{array}{l}\text { 3.1.8.10.2 Treatment } \\
\text { Container and Loadout } \\
\text { Drum }\end{array}$ & $\begin{array}{l}\text { receive treatment container and } \\
\text { loadout drum message from PCS }\end{array}$ & $\begin{array}{l}\text { 3.1.8/UP35, } 36,37 \text { have CLW } \\
\text { when "at airlock conveyor scale" } \\
\text { leaving process area }\end{array}$ & . & \\
\hline 3.2.1 User Interfaces & $\begin{array}{l}\text { All primary screens will have a } \\
\text { "fast access" capability, }\end{array}$ & $\begin{array}{l}\text { SDD para } 5.2 \text { refers to "fast } \\
\text { access" discussion in Section } 4.3 .1 \\
\text { - actual reference should be } 4.3 .2\end{array}$ & a "typo" update to the SDD & $\begin{array}{l}\text { Needs to be incorporated } \\
\text { into system/next SDD }\end{array}$ \\
\hline $\begin{array}{l}\text { 3.4.1 Standards } \\
\text { Compliance }\end{array}$ & $\begin{array}{l}\text { The system will be compatible } \\
\text { with the Site Naming } \\
\text { Conventions found in WHC-CM- } \\
2-6 \text {, Section } 3.6 \text { "Business } \\
\text { Naming Standard." }\end{array}$ & $\begin{array}{l}\text { no reference to site standards } \\
\text { except as pertains to SWITS } \\
\text { compatibility }\end{array}$ & $\begin{array}{l}\text { should reference standards - although it } \\
\text { is apparent that data naming standards } \\
\text { are being followed as defined for } \\
\text { Hanford }\end{array}$ & $\begin{array}{l}\text { Addressed during SDD "as- } \\
\text { built" revision }\end{array}$ \\
\hline 3.5.3 Security & $\begin{array}{l}\text { Host access control shall be used } \\
\text { to protect the system from } \\
\text { unauthorized access. }\end{array}$ & $\begin{array}{l}\text { SRS not clear on term "host } \\
\text { access" - could be defined as } \\
\text { access to the system environment } \\
\text { or as simple physical security over } \\
\text { terminals }\end{array}$ & SRS document needs to be clarified & $\begin{array}{l}\text { Needs to be addressed in } \\
\text { next revision of SRS }\end{array}$ \\
\hline
\end{tabular}




\subsection{SYSTEM DESIGN DOCUMENT (SDD) INTERNAL INTEGRITY}

\subsubsection{Purpose}

This analysis compares the discreet features and elements specified in the SDD Appendices and text. The intent is to determine the consistency of the design across each part of the specification to gauge the overall design integrity.

\subsubsection{Scope}

This analysis focuses on the SDD, which is composed of a general specification and eight appendices. Each appendix describes a different aspect of the detailed design. While each of these SDD sections has a distinct focus, they are very interdependent with frequent cross-references among them. This analysis traces these cross-references and examines consistency within them.

This analysis is divided into two phases. The first phase focused on the analysis directly supporting issues that need resolution for Phase 1 of the DMS development. The second phase of the analysis was conducted to support specification reviews and updates for Phase 2 of the DMS development.

\subsubsection{Description of Analysis Approach}

For Phase 1 of this analysis three types of matrices were prepared for all of the DMS Phase 1 modules:

- One matrix type compared the data dictionary in Appendix $\mathrm{C}$ to the data usage in the Appendix F Process Model.

- One matrix type compared the specifications and data used in Appendix $F$ with the general design screen navigation description, the screen design in Appendix A, and the data dictionary in Appendix C.

- One matrix type compared data definition consistency (i.e., the named data has the same data type and size) across Appendix $\mathrm{C}$ and the database record and table definitions. 
For Phase 2, the preceding matrices were updated to include Phase 2 and Phase 3 DMS modules, and three more matrix types were added:

- One matrix type to compare report contents in Appendix B with the data dictionary data contents and the Appendix $F$ specifications for these reports.

These detailed matrices are compiled in the DMS project files as working papers. They are in binders marked as "WRAP 1 DMS V\&V Analysis". They are available for review should questions arise regarding the source of the discrepancies and comments provided in this V\&V Report.

Comments in all matrices are intended to point out discrepancies in these comparisons, or other insights which the analyst deemed necessary to bring to the system owner's attention. Where comments pertain to discrepancies, these were categorized to reflect their potential severity or impact on the design. (See the Introduction section of this of V\&V Report for a definition of discrepancy categories.)

\subsubsection{Analytic Overview}

\subsubsection{General Observations}

In addition to the comments and discrepancies noted in the matrices, the following general comments are noted:

Category 2 concerns:

- Appendix E of the SDD was not reviewed for internal design integrity, but was a good source for detailed explanations of the intended drum tracking requirements. It is very oriented toward a functional description of process flow through the WRAP 1 facility. For this reason, it is recommended that Appendix $E$ be considered for incorporation into the SRS to replace the current SRS paragraph 3.1.8 discussion. The Appendix E matrix to be prepared during the second phase of this V\&V effort report could serve to help streamline the contents of Appendix $\mathrm{E}$ and support its inclusion in an SRS baseline document.

- In many cases, the pseudo-code in Appendix F provides an "English" description of data elements which are not then defined by data element name in the Attributes column of the process model. This tends to create uncertainty regarding which 
data element is actually being used and/or which table is being accessed. Some of this uncertainty is lessened if the developer is already intuitively aware of the interaction between the specification and its reliance on a different unit process in a different module. However, this relationship is not clearly referenced in the dependent unit process.

- Many Unit Processes in Appendix F cite required value entries for certain fields. In many cases, these required values are not noted as part of the domain definition for Appendix $\mathrm{C}$ definitions.

- The data dictionary is not always clear on its reference to data that is derived from or under data "ownership" in SWITS. Data element definitions should include this information for all affected data and tables.

- Screen specifications are missing for all System Administration and Maintenance screens and for the Main Menu screen in Appendix F.

- System administration, data base administration, and system developer/maintenance responsibilities are not clearly defined. Descriptions of these functions tend to overlap. The final determination of respective responsibilities and associated technical expertise required will affect some of the level of detail in development to support these functions.

- On many multi-window screens there are no add, delete, refresh, and commit buttons. Instead, these functions are automatically generated using ORACLE features or are dependent on parent level screens. While this approach will usually produce desired results, it deviates from some of the normal screen performance that the users become accustomed to on other screens. Even if redundant to builtin ORACLE features, consideration should be given to adding such buttons to preclude user confusion.

\section{General Category 3 Concerns:}

- The data stores affected by the Appendix F processes are not always listed. There appears to be a convention to list stores only when data is loaded into them (i.e., there is some update or edit affecting the data store), although in some cases not all stores are listed even for such updates. Since the stores are affected through either read or write operations, they should probably be listed for the sake of 
clarity. It is often confusing to gauge the source of data element used by the specifications when the pseudo-code refers only to "PIN" or "location". Citing the data store would clarify the specific data element needed.

- The general listing for data elements and tables describes numeric fields with the term "NUM". The definition listing for data elements and tables uses the term "NUMBER". These should be consistent in the dictionary.

\subsubsection{Discrepancy Synopsis and Resolution Matrices}

The following matrix contains a synopsis of the discrepancies which are described in the analytic matrices found in the DMS project files. This synopsis groups the discrepancies by matrix type and, within each matrix type, by discrepancy category. It then provides resolution actions which were decided during the course of the V\&V analysis. Those actions which are closed are also noted.

The resolution matrix will be considered a tracking mechanism to monitor all discrepancies until they are closed. Consequently, it will be periodically updated to reflect closed actions. Also, during Phase 2 and 3, the SDD will be updated to incorporate new and changed specifications for Phase 2 and 3 DMS modules. V\&V analysis will be conducted on these updates and resulting discrepancies will be incorporated into this matrix. 


\begin{tabular}{|c|c|c|c|c|}
\hline $\begin{array}{l}\text { APPENDIX F } \\
\text { PROCESS/UNIT } \\
\text { PROCESS }\end{array}$ & $\begin{array}{c}\text { APPENDIX C } \\
\text { DATA ELEMENT }\end{array}$ & DISCREPANCY & $\begin{array}{l}\text { RATIONALE FOR } \\
\text { CATEGORY }\end{array}$ & RESOLUTION \\
\hline \multicolumn{5}{|c|}{ PROCESS MODEL COMPARED TO DATA DICTIONARY } \\
\hline \multicolumn{5}{|c|}{ CATEGORY 1 DISCREPANCIES } \\
\hline \multirow[t]{2}{*}{$\begin{array}{l}\text { 3.1.1.2/UP4-13: Retrieve } \\
\text { drum or box data from } \\
\text { SWITS; } \\
\text { Generate DMS drum or box } \\
\text { container records }\end{array}$} & \multirow[t]{2}{*}{ none } & $\begin{array}{l}\text { Appendix F specifies copy of } \\
\text { (S)REDET_SWTYP_CD to data } \\
\text { element RDET_SWTYP_CD - no } \\
\text { such data element in Appendix C }\end{array}$ & \multirow[t]{2}{*}{$\begin{array}{l}\text { need to verify that data base } \\
\text { is not missing a data element } \\
\text { - mapping may be wrong }\end{array}$} & $\begin{array}{l}\text { 2/20/96: Test Proc. Review Meet: } \\
\text { later version of Appendix C (not the } \\
\text { one used for V\&V) has beenz updated } \\
\text { to include data element Discrepancy } \\
\text { Item Closed }\end{array}$ \\
\hline & & $\begin{array}{l}\text { Appendix F specifies copy of } \\
\text { (S)HDET_SCAT_CD into DMS } \\
\text { data element HDET_SCAT_CD - } \\
\text { no such data element in Appendix } \\
\text { C }\end{array}$ & & $\begin{array}{l}\text { 2/20/96: Test Proc. Review Meet: } \\
\text { pending review and confirmation that } \\
\text { SWITS SCAT_CD is of value to DMS } \\
\text { - either Appendix C needs to be } \\
\text { updated to incorporate data element or } \\
\text { it should be removed from Appendix } \\
\text { F. Decision: Update Appendix F } \\
\text { Action Completed and Discrepancy } \\
\text { Item Closed as of } 3 / 6 / 96\end{array}$ \\
\hline
\end{tabular}




\begin{tabular}{|c|c|c|c|c|}
\hline $\begin{array}{l}\text { APPENDIX F } \\
\text { PROCESS/UNIT } \\
\text { PROCESS }\end{array}$ & $\begin{array}{c}\text { APPENDIX C } \\
\text { DATA ELEMENT }\end{array}$ & DISCREPANCY & $\begin{array}{l}\text { RATIONALE FOR } \\
\text { CATEGORY }\end{array}$ & RESOLUTION \\
\hline & & $\begin{array}{l}\text { Appendix } F \text { specifies setting } \\
\text { ISO_WRAP_FLAG to " } Y " \text { - no } \\
\text { such data element in Appendix C }\end{array}$ & $\begin{array}{l}\text { need to verify that data base } \\
\text { is not missing a data element }\end{array}$ & $\begin{array}{l}\text { 2/20/96: Test Proc. Review Meet: } \\
\text { use of SIEISO table supersedes the } \\
\text { need for ISO_WRAP_FLAG - } \\
\text { Appendix F needs to be updated to } \\
\text { delete the reference to } \\
\text { ISO_WRAP_FLAG }\end{array}$ \\
\hline \multirow[t]{2}{*}{$\begin{array}{l}\text { 3.1.2.2/UP1-2: NDA Data } \\
\text { Review in the Control Room }\end{array}$} & & $\begin{array}{l}\text { Appendix F specifies comparison } \\
\text { between RADDETAIL and NDA } \\
\text { records: following specified data } \\
\text { elements are not listed in } \\
\text { Appendix C: } \\
\text { RDET_TOT_PU_FGE_TMU } \\
\text { RDET_TOT_PE_CI_TMU } \\
\text { RDET_THERMAL_POWER_- } \\
\text { TMU }\end{array}$ & & $\begin{array}{l}\text { Comments provided after review of } \\
\text { V\&V discrepancies: data element } \\
\text { should be added to Appendix C } \\
\text { Action Completed and Discrepancy } \\
\text { Item Closed as of } 3 / 6 / 96\end{array}$ \\
\hline & & $\begin{array}{l}\text { Appendix F specifies display of } \\
\text { USE_CD_DESCR - no such data } \\
\text { element in Appendix C - may be } \\
\text { referring to CONTYP_CD and } \\
\text { CNTYP_DESCR }\end{array}$ & & $\begin{array}{l}\text { Comments provided after review of } \\
\text { V\&V discrepancies: Appendix F } \\
\text { reference to USE_CD_DESCR should } \\
\text { be deleted } \\
\text { Action Completed and Discrepancy } \\
\text { Item Closed as of } 3 / 6 / 96\end{array}$ \\
\hline
\end{tabular}




\begin{tabular}{|c|c|c|c|c|}
\hline $\begin{array}{l}\text { APPENDIX F } \\
\text { PROCESS/UNIT } \\
\text { PROCESS }\end{array}$ & $\begin{array}{c}\text { APPENDIX C } \\
\text { DATA ELEMENT }\end{array}$ & DISCREPANCY & $\begin{array}{l}\text { RATIONALE FOR } \\
\text { CATEGORY }\end{array}$ & RESOLUTION \\
\hline & & $\begin{array}{l}\text { Appendix F specifies use of } \\
\text { NDA_NONLISTED_FLAG - no } \\
\text { such data element in Appendix C }\end{array}$ & & $\begin{array}{l}\text { Comments provided after review of } \\
\text { V\&V discrepancies: Appendix F } \\
\text { should be changed to } \\
\text { CONEXT_NLLL_DET_DT } \\
\text { Action Completed and Discrepancy } \\
\text { Item Closed as of } 3 / 6 / 96\end{array}$ \\
\hline . & & $\begin{array}{l}\text { Appendix F specifies use of } \\
\text { MSGLOG_FLAG - no such data } \\
\text { element - MSGLOG table only has } \\
\text { a MSGLOG_ERROR_FLAG } \\
\text { which does not seem to support } \\
\text { the intended processing }\end{array}$ & & $\begin{array}{l}\text { Comments provided after review of } \\
\text { V\&V discrepancies: Appendix F } \\
\text { reference to MSGLOG_FLAG should } \\
\text { be deleted. } \\
\text { Action Completed and Discrepancy } \\
\text { Item Closed as of } 3 / 6 / 96\end{array}$ \\
\hline $\begin{array}{l}\text { 3.1.2.2/UP3-5: NDA } \\
\text { Revisit }\end{array}$ & & $\begin{array}{l}\text { Appendix F specifies use of } \\
\text { PISO_PROF_NUM - no such data } \\
\text { element in Appendix C }\end{array}$ & & $\begin{array}{l}\text { Comments provided after review of } \\
\text { V\&V discrepancies: Appendix F } \\
\text { should be changed to PISO_PROF_ID } \\
\text { Action Completed and Discrepancy } \\
\text { Item Closed as of } 3 / 6 / 96\end{array}$ \\
\hline
\end{tabular}




\begin{tabular}{|c|c|c|c|c|}
\hline $\begin{array}{l}\text { APPENDLX F } \\
\text { PROCESS/UNIT } \\
\text { PROCESS }\end{array}$ & $\begin{array}{l}\text { APPENDIX C } \\
\text { DATA ELEMENT }\end{array}$ & DISCREPANCY & $\begin{array}{l}\text { RATIONALE FOR } \\
\text { CATEGORY }\end{array}$ & RESOLUTION \\
\hline $\begin{array}{l}\text { 3.1.3.1/UP 6-8: LLW Exit } \\
\text { Glovebox Product Drum } \\
\text { Update } \\
\text { 3.1.3.1/UP9: Create NDA } \\
\text { tecord for the product drum }\end{array}$ & & $\begin{array}{l}\text { Appendix F specifies } \\
\text { DEFAULT_PK_MTL_HGT - no } \\
\text { such data element in Appendix C } \\
\text { nor is there any apparent table that } \\
\text { would store it }\end{array}$ & $\begin{array}{l}\text { need to verify source and } \\
\text { update either specifications or } \\
\text { data dictionary - validate } \\
\text { against physical data base }\end{array}$ & $\begin{array}{l}\text { 1/30/96: Test Proc Review Meet: } \\
\text { need to update Appendix C to include } \\
\text { data element in WRAPMISC table } \\
\text { Action Completed and Discrepancy } \\
\text { Item Closed as of } 3 / 6 / 96\end{array}$ \\
\hline $\begin{array}{l}\text { 3.1.3.1/UP9: Create NDA } \\
\text { record for the product drum }\end{array}$ & unknown & $\begin{array}{l}\text { Appendix F cites two attributes of } \\
\text { "TBD" }\end{array}$ & $\begin{array}{l}\text { need to resolve to support } \\
\text { development }\end{array}$ & $\begin{array}{l}\text { 1/30/96: Test Proc Review Meet: } \\
\text { final decision on these data elements } \\
\text { pending - will be a combining of } \\
\text { HAZDETAIL and CHEMCOMP - } \\
\text { deferred to Phase } 2\end{array}$ \\
\hline $\begin{array}{l}\text { 3.1.3.2/UP2-4: Separation } \\
\text { of Compliant and Non- } \\
\text { Compliant Components }\end{array}$ & \multirow[t]{3}{*}{ none } & $\begin{array}{l}\text { Appendix F cites use of } \\
\text { MAT_PKG_ID - no such data } \\
\text { element in Appendix C }\end{array}$ & \multirow[t]{3}{*}{$\begin{array}{l}\text { need to verify that database is } \\
\text { not missing a data element. } \\
\text { (Phase } 2 \text { development?) }\end{array}$} & \multirow{3}{*}{$\begin{array}{l}\text { Data contents validated during testing. } \\
\text { Revised data dictionary to be published } \\
\text { as new baseline with "as-built" SDD } \\
\text { revision. Discrepancy Item Closed }\end{array}$} \\
\hline \multirow[t]{2}{*}{$\begin{array}{l}\text { 3.1.4/UP16-18: Display } \\
\text { samples available for } \\
\text { treatment on a pop-up screen }\end{array}$} & & $\begin{array}{l}\text { Appendix F cites use of } \\
\text { SAM_RETURN_DT - no such } \\
\text { data element in Appendix C }\end{array}$ & & \\
\hline & & $\begin{array}{l}\text { Appendix F cites use of } \\
\text { WORKSHEET_PKG_ID - no such } \\
\text { data element in Appendix C }\end{array}$ & & \\
\hline
\end{tabular}




\begin{tabular}{|c|c|c|c|c|}
\hline $\begin{array}{l}\text { APPENDIX F } \\
\text { PROCESS/UNIT } \\
\text { PROCESS }\end{array}$ & $\begin{array}{c}\text { APPENDIX C } \\
\text { DATA ELEMENT }\end{array}$ & DISCREPANCY & $\begin{array}{l}\text { RATIONALE FOR } \\
\text { CATEGORY }\end{array}$ & RESOLUTION \\
\hline $\begin{array}{l}\text { 3.1.4/UP24: Completion of } \\
\text { sample/bottle tracking data } \\
\text { (generally upon return of } \\
\text { samples to WRAP) }\end{array}$ & & $\begin{array}{l}\text { Appendix F cites use of } \\
\text { CONREL_USE_CD - no such } \\
\text { data element in Appendix C } \\
\text { - no value of 'O' for } \\
\text { CONEXT_USE_CD, if that is the } \\
\text { correct one }\end{array}$ & & \\
\hline $\begin{array}{l}\text { 3.1.5/UP12: DMS to } \\
\text { transmit all applicable } \\
\text { SWITS data to SWITS for } \\
\text { all drums received by } \\
\text { WRAP }\end{array}$ & & $\begin{array}{l}\text { Appendix F specifies } \\
\text { CON_SHIP_DT - no such data } \\
\text { element in Appendix H as a } \\
\text { SWITS data element }\end{array}$ & & $\begin{array}{l}\text { Comments provided after review of } \\
\text { V\&V discrepancies: CON_SHIP_DT } \\
\text { should be added to Appendix H } \\
\text { Action Completed and Discrepancy } \\
\text { Item Closed as of } 3 / 6 / 96\end{array}$ \\
\hline $\begin{array}{l}\text { 3.1.5/UP15: Archive } \\
\text { applicable WRAP data }\end{array}$ & & $\begin{array}{l}\text { Appendix F specifies SWIR330 - } \\
\text { no such data store in Appendix C }\end{array}$ & & $\begin{array}{l}\text { Comments provided after review of } \\
\text { V\&V discrepancies: Appendix F } \\
\text { reference to SWIR } 330 \text { should be } \\
\text { deleted } \\
\text { Action Completed and Discrepancy } \\
\text { Item Closed as of } 3 / 6 / 96\end{array}$ \\
\hline
\end{tabular}




\begin{tabular}{|c|c|c|c|c|}
\hline $\begin{array}{l}\text { APPENDIX F } \\
\text { PROCESS/UNIT } \\
\text { PROCESS }\end{array}$ & $\begin{array}{c}\text { APPENDIX C } \\
\text { DATA ELEMENT }\end{array}$ & DISCREPANCY & $\begin{array}{l}\text { RATIONALE FOR } \\
\text { CATEGORY }\end{array}$ & RESOLUTION \\
\hline & & $\begin{array}{l}\text { Appendix F specifies archiving } \\
\text { data to data store TRUPACT - no } \\
\text { such data store in Appendix C }\end{array}$ & & $\begin{array}{l}\text { Comments provided after review of } \\
\text { V\&V discrepancies: Appendix F } \\
\text { should be updated to delete TRUPACT } \\
\text { - add TRUPAY, TRUSHIP, and } \\
\text { TRUWASTE } \\
\text { Action Completed and Discrepancy } \\
\text { Item Closed as of } 3 / 6 / 96\end{array}$ \\
\hline \multirow[t]{2}{*}{$\begin{array}{l}\text { 3.1.6/UP9: TRUPACT } \\
\text { Assembly List Generation }\end{array}$} & & $\begin{array}{l}\text { Appendix F specifies display of } \\
\text { TRUPAY_ASBLY_ID - no such } \\
\text { data element in Appendix C }\end{array}$ & & \multirow{2}{*}{$\begin{array}{l}\text { 2/20/96: Test Proc Review Meet: } \\
\text { TRU processes to be further specified } \\
\text { during Phase } 3 \text { requirement reviews } \\
\text { and subsequent specification updates. } \\
\text { TRU and TRU RWM discrepancies } \\
\text { will be addressed during those } \\
\text { activities. }\end{array}$} \\
\hline & . & $\begin{array}{l}\text { Appendix } F \text { specifies display of } \\
\text { TRUPAY_POSTN - no such data } \\
\text { element in Appendix C }\end{array}$ & & \\
\hline \multirow[t]{2}{*}{$\begin{array}{l}\text { 3.1.6/UP10: Save Data to } \\
\text { File }\end{array}$} & & $\begin{array}{l}\text { Appendix F specifies display of } \\
\text { TRUPACT Assembly Pick List - } \\
\text { no such data element in Appendix } \\
\text { C }\end{array}$ & & \multirow[t]{2}{*}{$\begin{array}{l}\text { Phase } 2 / 3 \text { SDD updates to be } \\
\text { addressed as a result of feature } \\
\text { functional specification reviews }\end{array}$} \\
\hline & & $\begin{array}{l}\text { Appendix F specifies table } \\
\text { TRUPAY - no such table in } \\
\text { Appendix C }\end{array}$ & & \\
\hline
\end{tabular}




\begin{tabular}{|c|c|c|c|c|}
\hline $\begin{array}{l}\text { APPENDIX F } \\
\text { PROCESS/UNIT } \\
\text { PROCESS }\end{array}$ & $\begin{array}{c}\text { APPENDIX C } \\
\text { DATA ELEMENT }\end{array}$ & DISCREPANCY & $\begin{array}{l}\text { RATIONALE FOR } \\
\text { CATEGORY }\end{array}$ & RESOLUTION \\
\hline & & $\begin{array}{l}\text { Appendix } F \text { specifies display of } \\
\text { TRUPAY_SHIP_NUM - no such } \\
\text { data element in Appendix C }\end{array}$ & & \\
\hline & & $\begin{array}{l}\text { Appendix F specifies display of } \\
\text { TRUPAY_ASBLY ID-no such } \\
\text { data element in Appendix C }\end{array}$ & & \\
\hline $\begin{array}{l}\text { 3.1.8/UP9: Drum at LLW } \\
\text { Entry Glovebox Port }\end{array}$ & CON_CNTR_VOL & $\begin{array}{l}\text { specifies CON_CNTNR_VOL but } \\
\text { Appendix C has } \\
\text { CON_CNTR_VOL }\end{array}$ & $\begin{array}{l}\text { unclear which is proper data } \\
\text { element name to use - code } \\
\text { needs to be checked against } \\
\text { physical data base and SDD } \\
\text { updated }\end{array}$ & $\begin{array}{l}\text { 1/4/96: Test Proc Review Meet: } \\
\text { CNTNR is a typo - need to change } \\
\text { Appendix F } \\
\text { Action Completed and Discrepancy } \\
\text { Item Closed as of } 3 / 6 / 96\end{array}$ \\
\hline
\end{tabular}




\begin{tabular}{|c|c|c|c|c|}
\hline $\begin{array}{l}\text { APPENDIX F } \\
\text { PROCESS } / \text { NIT } \\
\text { PROCESS }\end{array}$ & $\begin{array}{c}\text { APPENDIX C } \\
\text { DATA ELEMENT }\end{array}$ & DISCREPANCY & $\begin{array}{l}\text { RATIONALE FOR } \\
\text { CATEGORY }\end{array}$ & RESOLUTION \\
\hline $\begin{array}{l}\text { 3.1.8/UP63: BWAS status } \\
\text { from BWAS } \\
\text { 3.1.8/UP64 BWAS status to } \\
\text { PCS } \\
\text { 3.1.8/UP78: SIE Status } \\
\text { from the SIE } \\
\text { 3.1.8/UP79: SIE Status to } \\
\text { the PCS } \\
\text { 3.1.8/UP85: DMS Status to } \\
\text { the PCS } \\
\text { 3.1.8/UP86: PCS Status } \\
\text { from the PCS }\end{array}$ & unclear & $\begin{array}{l}\text { unit process cites an equipment } \\
\text { error code - Appendix C only } \\
\text { seems to have an ERR_NUM in } \\
\text { ERRMESSAGE described for } \\
\text { SWITS errors - no others found }\end{array}$ & $\begin{array}{l}\text { unit process may be using } \\
\text { non-existent data element }\end{array}$ & $\begin{array}{l}\text { 1/4/96: Test Proc Review Meet: in } \\
\text { data element ERR_NUM of } \\
\text { ERRMESSAGE, definition refers to } \\
\text { Appendix E - } \\
\text { change Appendix C so it is not } \\
\text { SWITS-specific } \\
\text { Action Completed and Discrepancy } \\
\text { Item Closed as of } 3 / 6 / 96 \\
\text { add a table of error codes to Appendix } \\
\text { E and change the Appendix C domain } \\
\text { Action Completed and Included in } \\
\text { Rev } 2 \text { of SDD }\end{array}$ \\
\hline
\end{tabular}




\begin{tabular}{|c|c|c|c|c|}
\hline $\begin{array}{l}\text { APPENDIX F } \\
\text { PROCESS } / \text { NIT } \\
\text { PROCESS }\end{array}$ & $\begin{array}{c}\text { APPENDIX C } \\
\text { DATA ELEMENT }\end{array}$ & DISCREPANCY & $\begin{array}{l}\text { RATIONALE FOR } \\
\text { CATEGORY }\end{array}$ & RESOLUTION \\
\hline $\begin{array}{l}\text { 3.1.9/UP27-29: Data review } \\
\text { for drums which have } \\
\text { undergone processing in the } \\
\text { WRAP 1' Processing Area }\end{array}$ & none & $\begin{array}{l}\text { Appendix F specifies display of } \\
\text { HDET_SCAT_CD - no such data } \\
\text { element in Appendix C }\end{array}$ & $\begin{array}{l}\text { need to verify that data base } \\
\text { is not missing a data element }\end{array}$ & $\begin{array}{l}\text { 2/20/96: Test Proc. Review Meet: } \\
\text { pending review and confumation that } \\
\text { SWITS SCAT_CD is of value to DMS } \\
\text { - either Appendix C needs to be } \\
\text { updated to incorporate data element of } \\
\text { it should be removed from Appendix F } \\
\text { Decision: Update Appendix F } \\
\text { Action Completed and Discrepancy } \\
\text { Item Closed as of } 3 / 6 / 96\end{array}$ \\
\hline $\begin{array}{l}\text { 3.1.8/UP58: Treatment } \\
\text { Container and Item } \\
\text { Container relationship from } \\
\text { PCS }\end{array}$ & SAMLOC_BOTTLE_ID? & $\begin{array}{l}\text { Appendix F specifies use of } \\
\text { SAMLOC_PKG_ID - no such data } \\
\text { element in Appendix C }\end{array}$ & $\begin{array}{l}\text { may be a reference to } \\
\text { SAMPLOC_BOTTLE_ID - if } \\
\text { not, data base may be } \\
\text { missing a data element }\end{array}$ & \multirow[t]{2}{*}{$\begin{array}{l}\text { Phase } 2 / 3 \text { SDD updates to be } \\
\text { addressed as a result of feature } \\
\text { functional specification reviews }\end{array}$} \\
\hline $\begin{array}{l}\text { 3.1.8/UP101: TRUPACT } \\
\text { assembly complete from } \\
\text { PCS }\end{array}$ & none & $\begin{array}{l}\text { Appendix F specifies a TRUPACT } \\
\text { ID and "TBD" for data in this UP }\end{array}$ & $\begin{array}{l}\text { specification data and } \\
\text { processing of that data is not } \\
\text { defined }\end{array}$ & \\
\hline
\end{tabular}




\begin{tabular}{|c|c|c|c|c|}
\hline $\begin{array}{l}\text { APPENDDX F } \\
\text { PROCESS/UNIT } \\
\text { PROCESS }\end{array}$ & $\begin{array}{c}\text { APPENDIX C } \\
\text { DATA ELEMENT }\end{array}$ & DISCREPANCY & $\begin{array}{l}\text { RATIONALE FOR } \\
\text { CATEGORY }\end{array}$ & RESOLUTION \\
\hline \multicolumn{5}{|c|}{ CATEGORY 2 DISCREPANCIES } \\
\hline $\begin{array}{l}\text { 3.1.1.2/UP2: Receive drums } \\
\text { or boxes } \\
\text { Confirm drums or boxes on } \\
\text { SWITS }\end{array}$ & RECDISP_BLK_NUM & $\begin{array}{l}\text { Appendix F specifies } \\
\text { RECDISP_BLOCK_ } \\
\text { NUM }\end{array}$ & $\begin{array}{l}\text { need to verify data element } \\
\text { name against physical data } \\
\text { base and data dictionary }\end{array}$ & $\begin{array}{l}\text { 2/20/96: Test Proc. Review Meet: } \\
\text { need to update Appendix F - Appendix } \\
\mathrm{C} \text { data element is correct } \\
\text { Action Completed and Discrepancy } \\
\text { Item Closed as of } 3 / 6 / 96\end{array}$ \\
\hline $\begin{array}{l}\text { 3.1.1.2/UP3: Facility curie } \\
\text { limit check } \\
\text { User correct data }\end{array}$ & RADMAT_RAD_TOT & $\begin{array}{l}\text { Appendix F specifies } \\
\text { RADMAT_RAD_TOTAL }\end{array}$ & & $\begin{array}{l}\text { 2/20/96: Test Proc. Review Meet: } \\
\text { Appendix C is correct - need to update } \\
\text { Appendix F } \\
\text { Action Completed and Discrepancy } \\
\text { Item Closed as of } 3 / 6 / 96\end{array}$ \\
\hline
\end{tabular}




\begin{tabular}{|c|c|c|c|c|}
\hline $\begin{array}{l}\text { APPENDIX F } \\
\text { PROCESS/UNIT } \\
\text { PROCESS }\end{array}$ & $\begin{array}{l}\text { APPENDIX C } \\
\text { DATA ELEMENT }\end{array}$ & DISCREPANCY & $\begin{array}{l}\text { RATIONALE FOR } \\
\text { CATEGORY }\end{array}$ & RESOLUTION \\
\hline \multirow[t]{2}{*}{$\begin{array}{l}\text { 3.1.1.2/UP4-13: Retrieve } \\
\text { drum or data from SWITS } \\
\text { Generate DMS drum or box } \\
\text { container records }\end{array}$} & \multirow[t]{2}{*}{ none } & $\begin{array}{l}\text { Appendix F specifies SWITS data } \\
\text { store (S)RELOCHIST - not shown } \\
\text { in Appendix H as shared table }\end{array}$ & $\begin{array}{l}\text { table use/source needs to be } \\
\text { verified }\end{array}$ & \multirow{2}{*}{$\begin{array}{l}\text { 2/20/96: Test Proc. Review Meet: } \\
\text { need to reconcile Appendix F with } \\
\text { Appendix H - RELOC data and } \\
\text { RELOCHIST table of questionable } \\
\text { value to DMS } \\
\text { Decision: Appendix H needs to change } \\
\text { to note creation of RELOCHIST on } \\
\text { SWITS - record not stored on DMS - } \\
\text { CON_PKG_STATUS needs to be } \\
\text { added to Appendix C } \\
\text { Action Completed and Discrepancy } \\
\text { Item Closed as of } 3 / 6 / 96\end{array}$} \\
\hline & & $\begin{array}{l}\text { Appendix F specifies SWITS data: } \\
\text { (S)CON_PKG_STATUS } \\
\text { (S)RELOC_PKG_ID } \\
\text { (S)RELOC_DT } \\
\text { (S)RELOC_FROM_FACIL_ID } \\
\text { (S)RELOC_FROM_SECTION } \\
\text { (S)RELOC_FROM_UNIT } \\
\text { these are not listed in Appendix C } \\
\text { or H as being retrieved from } \\
\text { SWITS (CON_PKG_STATUS is } \\
\text { described as an upload to SWITS } \\
\text { from DMS only) }\end{array}$ & $\begin{array}{l}\text { data may not be available } \\
\text { from cited source }\end{array}$ & \\
\hline
\end{tabular}




\begin{tabular}{|c|c|c|c|c|}
\hline $\begin{array}{l}\text { APPENDIX F } \\
\text { PROCESS/UNIT } \\
\text { PROCESS }\end{array}$ & $\begin{array}{c}\text { APPENDIX C } \\
\text { DATA ELEMENT }\end{array}$ & DISCREPANCY & $\begin{array}{l}\text { RATIONALE FOR } \\
\text { CATEGORY }\end{array}$ & RESOLUTION \\
\hline & $\begin{array}{l}\text { HDET_PCB_REMOVED_ } \\
\text { DT }\end{array}$ & $\begin{array}{l}\text { Appendix F specifies } \\
\text { HDET_REMOVED_DT being } \\
\text { loaded from } \\
\text { (S)HDET_REMOVED_DT }\end{array}$ & $\begin{array}{l}\text { need to verify data element } \\
\text { name against physical data } \\
\text { base and data dictionary - } \\
\text { mapping may be wrong }\end{array}$ & $\begin{array}{l}\text { 2/20/96: Test Proc. Review Meet: } \\
\text { need to update Appendix F - Appendix } \\
\text { C data element is correct } \\
\text { Action Completed and Discrepancy } \\
\text { Item Closed as of } 3 / 6 / 96\end{array}$ \\
\hline \multirow[t]{3}{*}{$\begin{array}{l}3.1 .2 .2 / U P 1-2: \text { NDA. Data } \\
\text { Review in the Control Room }\end{array}$} & CONEXT_USE_CD & $\begin{array}{l}\text { Appendix F specifies USE_CODE } \\
\text { - no such data element in } \\
\text { Appendix C - possible reference to } \\
\text { CONEXT_USE_CD. }\end{array}$ & \multirow[t]{3}{*}{$\begin{array}{l}\text { need to verify intended data } \\
\text { element name }\end{array}$} & $\begin{array}{l}\text { Comments provided after review of } \\
\text { V\&V discrepancies: need to update } \\
\text { Appendix } F \text { - Appendix C is correct } \\
\text { Action Completed and Discrepancy } \\
\text { Item Closed as of } 3 / 6 / 96\end{array}$ \\
\hline & NDA_TMU_PU_FGE & $\begin{array}{l}\text { Appendix F specifies } \\
\text { NDA_TOT_PU_FGE_TMU - no } \\
\text { such data element in Appendix C - } \\
\text { possible reference to } \\
\text { NDA_TMU_PU_FGE? }\end{array}$ & & $\begin{array}{l}\text { Comments provided after review of } \\
\text { V\&V discrepancies: need to update } \\
\text { Appendix F - Appendix C is correct } \\
\text { Action Completed and Discrepancy } \\
\text { Item Closed as of } 3 / 6 / 96\end{array}$ \\
\hline & NDA_TMU_PE_CI & $\begin{array}{l}\text { Appendix. F specifies } \\
\text { NDA_TOT_PE_CI_TMU -no such } \\
\text { data element in Appendix C - } \\
\text { possible reference to } \\
\text { NDA_TMU_PE_CI }\end{array}$ & & $\begin{array}{l}\text { Comments provided after review of } \\
\text { V\&V discrepancies:need to update } \\
\text { Appendix F - Appendix C is correct } \\
\text { Action Completed and Discrepancy } \\
\text { Item Closed as of } 3 / 6 / 96\end{array}$ \\
\hline
\end{tabular}




\begin{tabular}{|c|c|c|c|c|}
\hline $\begin{array}{l}\text { APPENDIX F } \\
\text { PROCESS/UNIT } \\
\text { PROCESS }\end{array}$ & $\begin{array}{c}\text { APPENDIX C } \\
\text { DATA ELEMENT }\end{array}$ & DISCREPANCY & $\begin{array}{l}\text { RATIONALE FOR } \\
\text { CATEGORY }\end{array}$ & RESOLUTION \\
\hline . & $\begin{array}{l}\text { NDA_TMU_THERMAL } \\
\text { _POWER }\end{array}$ & $\begin{array}{l}\text { Appendix F specifies } \\
\text { NDA_THERMAL_POWER_TMU } \\
\text { - no such data element in } \\
\text { Appendix C - possible reference to } \\
\text { NDA_TMU_THERMAL__ } \\
\text { POWER - }\end{array}$ & & $\begin{array}{l}\text { Comments provided after review of } \\
\text { V\&V discrepancies:need to update } \\
\text { Appendix F - Appendix C is correct } \\
\text { Action Completed and Discrepancy } \\
\text { Item Closed as of } 3 / 6 / 96\end{array}$ \\
\hline $\begin{array}{l}\text { 3.1.3.1/UP1: LLW } \\
\text { Glovebox Drum Status at } \\
\text { Entry } \\
\text { 3.1.3.1/UP2: LLW Sorting } \\
\text { Table }\end{array}$ & none & $\begin{array}{l}\text { no table specified for messages to } \\
\text { be displayed - hard coded? }\end{array}$ & $\begin{array}{l}\text { data dictionary may not be } \\
\text { complete }\end{array}$ & $\begin{array}{l}\text { 1/30/96: Test Proc Review Meet: } \\
\text { messages are hard coded and not } \\
\text { stored in any table } \\
\text { Discrepancy Item Closed }\end{array}$ \\
\hline $\begin{array}{l}\text { 3.1.3.1/UP3-5: LLW Non- } \\
\text { Compliant Packet }\end{array}$ & CONR_REL_CODE & $\begin{array}{l}\text { Appendix F specifies } \\
\text { CONREL_CODE }\end{array}$ & \multirow{3}{*}{$\begin{array}{l}\text { need to verify data element } \\
\text { name against physical data } \\
\text { base and data dictionary }\end{array}$} & $\begin{array}{l}\text { 1/30/96: Test Proc Review Meet: } \\
\text { Appendix F should be updated. }\end{array}$ \\
\hline \multirow{2}{*}{$\begin{array}{l}\text { 3.1.3.1/UP6-8: LLW Exit } \\
\text { Glovebox Product Drum } \\
\text { Update }\end{array}$} & CONLOC_LOC_ID & $\begin{array}{l}\text { Appendix } F \text { specifies } \\
\text { CONLOC_ID }\end{array}$ & & Item Closed as of $3 / 6 / 96$ \\
\hline & $\begin{array}{l}\text { CONEXT_VER_GROSS_ } \\
\text { WGT }\end{array}$ & $\begin{array}{l}\text { Appendix } F \text { specifies } \\
\text { CONEXT_WGT }\end{array}$ & & $\begin{array}{l}\text { 1/30/96: Test Proc Review Meet: } \\
\text { Appendix F should be } \\
\text { CON_GROSS_WGT } \\
\text { Action Completed and Discrepancy } \\
\text { Item Closed as of } 3 / 6 / 96\end{array}$ \\
\hline
\end{tabular}




\begin{tabular}{|c|c|c|c|c|}
\hline $\begin{array}{l}\text { APPENDIX F } \\
\text { PROCESS/UNIT } \\
\text { PROCESS }\end{array}$ & $\begin{array}{c}\text { APPENDIX C } \\
\text { DATA ELEMENT }\end{array}$ & DISCREPANCY & $\begin{array}{l}\text { RATIONALE FOR } \\
\text { CATEGORY }\end{array}$ & RESOLUTION \\
\hline $\begin{array}{l}\text { 3.1.3.1/UP9: Create NDA } \\
\text { record for the product drum }\end{array}$ & $\begin{array}{l}\text { NDA_THERMAL_ } \\
\text { POWER or } \\
\text { NDA_TMU_THERMAL_- } \\
\text { POWER }\end{array}$ & $\begin{array}{l}\text { Appendix F specifies } \\
\text { NDA_TOT_THERMAL_ } \\
\text { POWER }\end{array}$ & & $\begin{array}{l}\text { 1/30/96: Test Proc Review Meet: } \\
\text { pending SCR - upon approval, } \\
\text { Appendix F should be updated to } \\
\text { NDA_THERMAL_POWER } \\
\text { Action Completed and Discrepancy } \\
\text { Item Closed as of } 3 / 6 / 96\end{array}$ \\
\hline $\begin{array}{l}\text { 3.1.3.1/UP10-13: Create } \\
\text { NDAISO records for the } \\
\text { product drum }\end{array}$ & WRAPMISC table & $\begin{array}{l}\text { Appendix F specifies } \\
\text { LLW_DEFLT_PROF as a data } \\
\text { element in WRAPMISC - no such } \\
\text { data element listed }\end{array}$ & & $\begin{array}{l}\text { 1/30/96: Test Proc Review Meet: } \\
\text { recently incorporated into Appendix C } \\
\text { WRAPMISC table - Appendix C } \\
\text { should be updated } \\
\text { Action Completed and Discrepancy } \\
\text { Item Closed as of } 3 / 6 / 96\end{array}$ \\
\hline $\begin{array}{l}\text { 3.1.3.2/UP7-8: Compliant } \\
\text { Waste Loadout }\end{array}$ & CODE_FIELD_NAME & $\begin{array}{l}\text { Appendix } F \text { specifies a value entry } \\
\text { in this field = VolD - does not } \\
\text { seem to be a valid entry or use of } \\
\text { this field as defined in Appendix C }\end{array}$ & $\begin{array}{l}\text { does not appear that logic } \\
\text { check to support program } \\
\text { will occur as intended }\end{array}$ & $\begin{array}{l}\text { Data contents validated during testing. } \\
\text { Revised data dictionary to be published } \\
\text { as new baseline with "as-built" SDD } \\
\text { revision. Discrepancy Item Closed }\end{array}$ \\
\hline $\begin{array}{l}\text { 3.1.4/UP1: Lab Sample } \\
\text { Acquisition }\end{array}$ & SAM_MATRIX_CD (?) & $\begin{array}{l}\text { Appendix F specifies field named } \\
\text { SAM_MATRIX - no such field in } \\
\text { Appendix C - appears to intend } \\
\text { use of SAM_MATRIX_CD with } \\
\text { LOV to SAMPMATX_CD }\end{array}$ & $\begin{array}{l}\text { either data dictionary is out } \\
\text { of sync with data base, or } \\
\text { specs do not use correct data } \\
\text { element }\end{array}$ & $\begin{array}{l}\text { Phase } 2 / 3 \text { SDD updates to be } \\
\text { addressed as a result of feature } \\
\text { functional specification reviews }\end{array}$ \\
\hline
\end{tabular}




\begin{tabular}{|c|c|c|c|c|}
\hline $\begin{array}{l}\text { APPENDIX F } \\
\text { PROCESS/UNIT } \\
\text { PROCESS }\end{array}$ & $\begin{array}{l}\text { APPENDIX C } \\
\text { DATA ELEMENT }\end{array}$ & DISCREPANCY & $\begin{array}{l}\text { RATIONALE FOR } \\
\text { CATEGORY }\end{array}$ & RESOLUTION \\
\hline $\begin{array}{l}\text { 3.1.4/UP2-3: Purge Port } \\
\text { Inventory Listing } \\
\text { 3.1.4/UP16-18: Display } \\
\text { samples for treatment on a } \\
\text { pop-up screen } \\
\text { 3.1.4/UP24: Completion of } \\
\text { sample/bottle tracking data } \\
\text { (generally upon return of } \\
\text { samples to WRAP) }\end{array}$ & $\begin{array}{l}\text { SAMREL_BOTTLE_ID } \\
\text { (?) }\end{array}$ & $\begin{array}{l}\text { Appendix F specifies field named } \\
\text { SAMREL_SAMPLE_ID - no such } \\
\text { field in Appendix F - probably } \\
\text { intend use of } \\
\text { SAMREL_BOTTLE_ID }\end{array}$ & & \multirow[t]{3}{*}{$\begin{array}{l}\text { Data contents validated during testing. } \\
\text { Revised data dictionary to be published } \\
\text { as new baseline with "as-built" SDD } \\
\text { revision. Discrepancy Item Closed }\end{array}$} \\
\hline $\begin{array}{l}\text { 3.1.4/UP4-5: Initiate Chain } \\
\text { of Custody tracking as } \\
\text { samples are removed from } \\
\text { the gloveboxes }\end{array}$ & CON_PKG_ID (?) & $\begin{array}{l}\text { Appendix F specifies pig PIN - } \\
\text { intention could be to display } \\
\text { CON_PKG_ID for } \\
\text { CONEXT_USE_CD ='TP" }\end{array}$ & $\begin{array}{l}\text { need to confirm data element } \\
\text { and table access }\end{array}$ & \\
\hline $\begin{array}{l}\text { 3.1.4/UP6-7: Field } \\
\text { Screening and data input to } \\
\text { support verification of waste } \\
\text { data or taking of lab samples }\end{array}$ & SCRN_ID (?) & $\begin{array}{l}\text { Appendix F cites use of } \\
\text { SCRN_SAMPLE_ID - no such } \\
\text { data element in Appendix C - } \\
\text { probably intend use of SCRN_ID }\end{array}$ & $\begin{array}{l}\text { either data dictionary is out } \\
\text { of sync with data base, or } \\
\text { specs do not use correct data } \\
\text { element }\end{array}$ & \\
\hline
\end{tabular}




\begin{tabular}{|c|c|c|c|c|}
\hline $\begin{array}{l}\text { APPENDIX F } \\
\text { PROCESS/UNIT } \\
\text { PROCESS }\end{array}$ & $\begin{array}{c}\text { APPENDIX C } \\
\text { DATA ELEMENT }\end{array}$ & DISCREPANCY & $\begin{array}{l}\text { RATIONALE FOR } \\
\text { CATEGORY }\end{array}$ & RESOLUTION \\
\hline & FIELD_SCRN_ID (?) & $\begin{array}{l}\text { Appendix F cites use of } \\
\text { FIELD_SAMPLE_ID - no such } \\
\text { data element in Appendix C - } \\
\text { probably intend use of } \\
\text { FIELD_SCRN_ID }\end{array}$ & & \\
\hline $\begin{array}{l}\text { 3.1.4/UP9: Selection of } \\
\text { method for obtaining lab } \\
\text { samples. Number of sample } \\
\text { bottles and analysis method } \\
\text { are also defined. }\end{array}$ & $\begin{array}{l}\text { BOTANAL_BOTTLE_ID } \\
\text { (?) }\end{array}$ & $\begin{array}{l}\text { Appendix F cites use of } \\
\text { BOT_ANALYSIS_CD - no such } \\
\text { data element in Appendix C - } \\
\text { probably intend use of } \\
\text { BOTANAL_BOTTLE_ID }\end{array}$ & & \\
\hline $\begin{array}{l}\text { 3.1.4/UP12: Generation of } \\
\text { Worksheet data in support of } \\
\text { RWM Processing - Display } \\
\text { all currently defined } \\
\text { worksheets }\end{array}$ & WORKITEM_ID (?) & $\begin{array}{l}\text { Appendix F cites use of } \\
\text { WORKSHEET_ID - no such data } \\
\text { element in Appendix C - probably } \\
\text { intend use of WORKITEM_ID }\end{array}$ & & \\
\hline $\begin{array}{l}\text { 3.1.4/UP14-15: Display } \\
\text { packets available for } \\
\text { treatment on a pop-up screen }\end{array}$ & & $\begin{array}{l}\text { Appendix F cites use of } \\
\text { WORKSHEET_PKG_ID - no such } \\
\text { data element in Appendix C - } \\
\text { probably intend use of } \\
\text { WORKITEM_ID }\end{array}$ & & \\
\hline
\end{tabular}




\begin{tabular}{|c|c|c|c|c|}
\hline $\begin{array}{l}\text { APPENDIX F } \\
\text { PROCESS/UNIT } \\
\text { PROCESS }\end{array}$ & $\begin{array}{c}\text { APPENDIX C } \\
\text { DATA ELEMENT }\end{array}$ & DISCREPANCY & $\begin{array}{l}\text { RATIONALE FOR } \\
\text { CATEGORY }\end{array}$ & RESOLUTION \\
\hline $\begin{array}{l}\text { 3.1.4/UP25: Update purge. } \\
\text { port or pig location }\end{array}$ & N/A & $\begin{array}{l}\text { Appendix F cites use of location } \\
\text { code SAMPLE_MGT - no such } \\
\text { location code in Appendix E }\end{array}$ & $\begin{array}{l}\text { may be missing a needed } \\
\text { location code or Appendix } F \\
\text { should cite a more } \\
\text { appropriate one }\end{array}$ & \\
\hline $\begin{array}{l}\text { 3.1.5/UP1: Selection of } \\
\text { WRAP shipment to be } \\
\text { completed } \\
\text { 3.1.5/UP8: Update of the } \\
\text { Uniform Hazardous Waste } \\
\text { Manifest (One form per } \\
\text { shipment for every shipment } \\
\text { leaving WRAP) }\end{array}$ & $\begin{array}{l}\text { SHIPWRAP_MFST_NUM } \\
?\end{array}$ & $\begin{array}{l}\text { Appendix } F \text { has } \\
\text { SHIPWRAP_MAN_NUM }\end{array}$ & \multirow[t]{2}{*}{$\begin{array}{l}\text { need to verify data element } \\
\text { name against physical data } \\
\text { base and data dictionary }\end{array}$} & \multirow[t]{2}{*}{$\begin{array}{l}\text { Comments provided after review of } \\
\text { V\&V discrepancies: Appendix F } \\
\text { should be updated } \\
\text { Action Completed and Discrepancy } \\
\text { Item Closed as of } 3 / 6 / 96\end{array}$} \\
\hline $\begin{array}{l}\text { 3.1.5/UP2: Update of the } \\
\text { Onsite Radioactive Shipment } \\
\text { Record (One form per } \\
\text { shipment for every shipment } \\
\text { leaving WRAP) Shipment } \\
\text { To and From data completed }\end{array}$ & ISO_UNIT? & Appendix F specifies ISO_UNITS & & \\
\hline
\end{tabular}




\begin{tabular}{|c|c|c|c|c|}
\hline $\begin{array}{l}\text { APPENDIX F } \\
\text { PROCESS/UNIT } \\
\text { PROCESS }\end{array}$ & $\begin{array}{c}\text { APPENDIX C } \\
\text { DATA ELEMENT }\end{array}$ & DISCREPANCY & $\begin{array}{l}\text { RATIONALE FOR } \\
\text { CATEGORY }\end{array}$ & RESOLUTION \\
\hline $\begin{array}{l}\text { 3.1.5/UP3: Carrier data } \\
\text { input }\end{array}$ & $\begin{array}{l}\text { SHIPWRAP_CARRIER } \\
\text { _PERS_ID }\end{array}$ & $\begin{array}{l}\text { Appendix } F \text { specifies } \\
\text { SHIPWRAP_CARRIER_- } \\
\text { PERSON }\end{array}$ & & \\
\hline $\begin{array}{l}\text { 3.1.5/UP5: Detailed } \\
\text { Packaging Description } \\
\text { entered }\end{array}$ & $\begin{array}{l}\text { computed value? stored in } \\
\text { SHPITM_CNTR_COUNT } \\
?\end{array}$ & $\begin{array}{l}\text { Appendix F specifies display sum } \\
\text { of PINS for shipment }\end{array}$ & $\begin{array}{l}\text { no attribute for store noted - } \\
\text { unclear if simple screen } \\
\text { display }\end{array}$ & $\begin{array}{l}\text { Comments provided after later } \\
\text { review of V } \& V \text { discrepancies: local } \\
\text { variable only - not a data base element } \\
\text { - count from UP1 query - "sum" is } \\
\text { poor choice of words: "count" would } \\
\text { have been better - however, screen } \\
\text { works as specified } \\
\text { Discrepancy Item Closed as of } \\
5 / 16 / 96\end{array}$ \\
\hline $\begin{array}{l}\text { 3.1.5/UP8: Update of the } \\
\text { Uniform Hazardous Waste } \\
\text { Manifest (One form per } \\
\text { shipment for every shipment } \\
\text { leaving WRAP) }\end{array}$ & $\begin{array}{l}\text { SHIPWRAP_MFST_ } \\
\text { COMP_FLAG? }\end{array}$ & $\begin{array}{l}\text { Appendix C specifies } \\
\text { SHIPWRAP_MAN_COMP_ } \\
\text { FLAG }\end{array}$ & $\begin{array}{l}\text { need to verify data element } \\
\text { name against physical data } \\
\text { base and data dictionary }\end{array}$ & $\begin{array}{l}\text { Comments provided after review of } \\
\text { V\&V discrepancies: Appendix F } \\
\text { should be updated Action Completed } \\
\text { and Discrepancy Item Closed as of } \\
\text { 3/6/96 }\end{array}$ \\
\hline
\end{tabular}




\begin{tabular}{|c|c|c|c|c|}
\hline $\begin{array}{l}\text { APPENDIX F } \\
\text { PROCESS/UNIT } \\
\text { PROCESS }\end{array}$ & $\begin{array}{c}\text { APPENDIX C } \\
\text { DATA ELEMENT }\end{array}$ & DISCREPANCY & $\begin{array}{l}\text { RATIONALE FOR } \\
\text { CATEGORY }\end{array}$ & RESOLUTION \\
\hline \multirow{2}{*}{$\begin{array}{l}\text { 3.1.5/UP12: DMS to } \\
\text { transmit all applicable } \\
\text { SWITS data to SWITS for } \\
\text { all drums received } \\
\text { 3.1.5/UP20: DMS to } \\
\text { transmit all applicable } \\
\text { SWITS data to SWITS for } \\
\text { all boxes and empty drums } \\
\text { received by WRAP }\end{array}$} & none & $\begin{array}{l}\text { Appendix F cites } \\
\text { CON_PKG_STATUS code of 'A' } \\
\text { - Appendix C does not define valid } \\
\text { values for CON_PKG_STATUS or } \\
\text { PKGSTAT table }\end{array}$ & $\begin{array}{l}\text { need to verify and list the } \\
\text { data element domain to } \\
\text { determine if this logic is } \\
\text { correct }\end{array}$ & $\begin{array}{l}\text { Data contents validated during testing. } \\
\text { Revised data dictionary to be published } \\
\text { as new baseline with "as-built" SDD } \\
\text { revision. Discrepancy Item Closed }\end{array}$ \\
\hline & N/A & $\begin{array}{l}\text { Appendix } F \text { cites upload to } \\
\text { MANIFEST(S) - this table is not } \\
\text { listed in Appendix } H\end{array}$ & $\begin{array}{l}\text { appears SWITS upload specs } \\
\text { may be missing one of the } \\
\text { table updates }\end{array}$ & $\begin{array}{l}\text { 05/02/96: Test Proc Review Meet: } \\
\text { SDD needs updated-combination of } \\
\text { uploads from SHIPHIST, SHIPMENT, } \\
\text { \& SHIPITEM fulfill manifest } \\
\text { recording requirements-no } \\
\text { MANIFEST(S) involved }\end{array}$ \\
\hline $\begin{array}{l}\text { 3.1.5/UP13: DMS to } \\
\text { transmit data to SWITS to } \\
\text { document the verification of } \\
\text { generator supplied data }\end{array}$ & $\begin{array}{l}\text { RDET_WRAP_VERF_ } \\
\text { FLAG }^{-}\end{array}$ & $\begin{array}{l}\text { Appendix H states all data } \\
\text { elements in RADDETAIL are } \\
\text { copied and then lists the minimum } \\
\text { that is required - this data element } \\
\text { is not one of those }\end{array}$ & $\begin{array}{l}\text { SWITS data transfer may not } \\
\text { be correct }\end{array}$ & $\begin{array}{l}\text { Comments provided after review of } \\
\text { V\&V discrepancies: data element } \\
\text { should be deleted from Appendix C - } \\
\text { VERIFICATION table will be used } \\
\text { instead. Action Completed and } \\
\text { Discrepancy Item Closed as of } 3 / 6 / 96\end{array}$ \\
\hline
\end{tabular}




\begin{tabular}{|c|c|c|c|c|}
\hline $\begin{array}{l}\text { APPENDIX F } \\
\text { PROCESS/UNIT } \\
\text { PROCESS }\end{array}$ & $\begin{array}{c}\text { APPENDIX C } \\
\text { DATA ELEMENT }\end{array}$ & DISCREPANCY & $\begin{array}{l}\text { RATIONALE FOR } \\
\text { CATEGORY }\end{array}$ & RESOLUTION \\
\hline $\begin{array}{l}\text { 3.1.5/UP15: Archive } \\
\text { applicable WRAP data } \\
\text { 3.1.5/UP23: Archive } \\
\text { applicable WRAP data }\end{array}$ & \multirow[t]{2}{*}{ all } & \multirow[t]{2}{*}{$\begin{array}{l}\text { these two unit processes are } \\
\text { identical in name, intent,. content }\end{array}$} & \multirow[t]{2}{*}{$\begin{array}{l}\text { should simplify with } \\
\text { elimination of one or the } \\
\text { other }\end{array}$} & \multirow[t]{3}{*}{$\begin{array}{l}\text { Phase } 2 / 3 \text { SDD updates to be } \\
\text { addressed as a result of feature } \\
\text { functional specification reviews }\end{array}$} \\
\hline \multirow{2}{*}{$\begin{array}{l}\text { 3.1.5/UP14: Update of PCS } \\
\text { database and adjust } \\
\text { radiologic inventory for the } \\
\text { facility } \\
\text { 3.1.5/UP22: Update of PCS } \\
\text { database and adjust } \\
\text { radiologic inventory for the } \\
\text { facility }\end{array}$} & & & & \\
\hline & $N / A$ & $\begin{array}{l}\text { specifies screen } 605 \text { data } \mathrm{TO} \text { a } \mathrm{CL} \\
\text { message as specified in } \\
3.1 .8 / \mathrm{UP} 41-3.1 .8 \text { specification } \\
\text { indicates this message is generated } \\
\text { from screen } 602\end{array}$ & $\begin{array}{l}\text { Appendix } F \text { inconsistent } \\
\text { across the } 3.1 .5 \text { and the } 3.1 .8 \\
\text { modules' }\end{array}$ & \\
\hline $\begin{array}{l}\text { 3.1.6/UP1: Process List } \\
\text { Additions }\end{array}$ & $\begin{array}{l}\text { unclear: } \\
\text { PROCADD_SEQ_NUM or } \\
\text { PROC_SEQ_NUM }\end{array}$ & $\begin{array}{l}\text { Appendix F cites column with Seq } \\
\text { - unclear on which sequence } \\
\text { number to use }\end{array}$ & $\begin{array}{l}\text { may be retrieving wrong data } \\
\text { element }\end{array}$ & $\begin{array}{l}\text { 2/20/96: Test Proc. Review Meet: } \\
\text { update Appendix F to cite correct data } \\
\text { element } \\
\text { Action Completed and Discrepancy } \\
\text { Item Closed as of } 3 / 6 / 96\end{array}$ \\
\hline
\end{tabular}




\begin{tabular}{|c|c|c|c|c|}
\hline $\begin{array}{l}\text { APPENDIX F } \\
\text { PROCESS/UNIT } \\
\text { PROCESS }\end{array}$ & $\begin{array}{c}\text { APPENDIX C } \\
\text { DATA ELEMIENT }\end{array}$ & DISCREPANCY & $\begin{array}{l}\text { RATIONALE FOR } \\
\text { CATEGORY }\end{array}$ & RESOLUTION \\
\hline & unclear: ERR_DESCR? & $\begin{array}{l}\text { Appendix } F \text { specifies show error } \\
\text { for "Duplicate PIN already on } \\
\text { Process List" - no reference to } \\
\text { ERRMESSAGE table }\end{array}$ & $\begin{array}{l}\text { unclear if a table access or if } \\
\text { hard coded - error lookup } \\
\text { values not contained in } \\
\text { Appendix C }\end{array}$ & $\begin{array}{l}\text { 1/4/96: Test Proc. Review Meet: add } \\
\text { a table of error codes to Appendix E } \\
\text { and change the Appendix C domain - } \\
\text { Additional information provided } \\
\text { after V\&V review: Appendix E table } \\
\text { only lists messages related to } \\
\text { DMSCOM - ERRMESSAGE table is } \\
\text { viewable via the Error Message Table } \\
\text { screen under System Admain- } \\
\text { meanwhile Appendix C updated in Rev } \\
2 \text { of SDD } \\
\text { Action Completed and Discrepancy } \\
\text { Item Closed as of } 5 / 16 / 96\end{array}$ \\
\hline \multirow[t]{2}{*}{ 3.1.6/UP2-4: Process List } & PROC_PROF_ID (?) & $\begin{array}{l}\text { Appendix F specifies } \\
\text { PROC_PROFILE_ID }\end{array}$ & \multirow[t]{2}{*}{$\begin{array}{l}\text { need to verify data element } \\
\text { name against physical data } \\
\text { base and data dictionary }\end{array}$} & \multirow{2}{*}{$\begin{array}{l}\text { Comments provided after review of } \\
\text { V\&V discrepancies: Appendix } F \\
\text { should be updated } \\
\text { Action Completed and Discrepancy } \\
\text { Item Closed as of } 3 / 6 / 96\end{array}$} \\
\hline & $\begin{array}{l}\text { CONEXT_WRAP_STAT_ } \\
\mathrm{CD}(?)\end{array}$ & $\begin{array}{l}\text { Appendix F specifies } \\
\text { CONEXT_WRAP_STATUS_ } \\
\text { CD }\end{array}$ & & \\
\hline
\end{tabular}


WRAP 1 DMS VALIDATION AND

VERIFICATION REPORT
HNF-1783

Revision 0

September 27, 1996

\begin{tabular}{|c|c|c|c|c|}
\hline $\begin{array}{l}\text { APPENDIX F } \\
\text { PROCESS/UNIT } \\
\text { PROCESS }\end{array}$ & $\begin{array}{c}\text { APPENDIX C } \\
\text { DATA ELEMENT }\end{array}$ & DISCREPANCY & $\begin{array}{l}\text { RATIONALE FOR } \\
\text { CATEGORY }\end{array}$ & RESOLUTION \\
\hline $\begin{array}{l}\text { 3.1.6/UP10: Save Data to } \\
\text { File }\end{array}$ & PROC_PKG_IDs? & $\begin{array}{l}\text { Appendix F specifies display of } \\
\text { cask assembly PINs }\end{array}$ & $\begin{array}{l}\text { need to clarify table access - } \\
\text { may be related to TRUPAY } \\
\text { discussions in Category } 1 \\
\text { discrepancies }\end{array}$ & $\begin{array}{l}\text { Comments provided after review of } \\
\text { V\&V discrepancies: } \\
\text { PAYLOAD_PKG_ID is correct data } \\
\text { element for this process, because this } \\
\text { is a TRUPACT Assembly pick list, } \\
\text { not a process pick list } \\
\text { Discrepancy Item Closed as of } \\
\text { 5/16/96 }\end{array}$ \\
\hline $\begin{array}{l}\text { 3.1.7/UP1: Radiologic } \\
\text { Inventory Summary }\end{array}$ & RADMAT_RAD_TOT & $\begin{array}{l}\text { Appendix F specifies } \\
\text { RADMAT_RAD_TOTAL }\end{array}$ & $\begin{array}{l}\text { need to verify data element } \\
\text { name against physical data } \\
\text { base and data dictionary }\end{array}$ & $\begin{array}{l}\text { 2/20/96: Test Proc. Review Meet: } \\
\text { Appendix C is correct - need to update } \\
\text { Appendix F } \\
\text { Action Completed and Discrepancy } \\
\text { Item Closed as of } 3 / 6 / 96\end{array}$ \\
\hline $\begin{array}{l}\text { 3.1.8/UP1: Log all } \\
\text { Messages }\end{array}$ & MSGLOG_ERROR_FLAG & $\begin{array}{l}\text { cites } \\
\text { MSGLOG_ERROR_TRANS_FLA } \\
\text { G but Appendix C has } \\
\text { MSGLOG_ERROR_FLAG }\end{array}$ & $\begin{array}{l}\text { unclear which is proper data } \\
\text { element name to use - name } \\
\text { needs to be checked against } \\
\text { physical data base and SDD } \\
\text { updated }\end{array}$ & $\begin{array}{l}\text { 1/4/96: Test Proc Review Meet: drop } \\
\text { the "TRANS" in Appendix F } \\
\text { Action Completed and Discrepancy } \\
\text { Item Closed as of } 3 / 6 / 96\end{array}$ \\
\hline
\end{tabular}


WRAP 1 DMS VALIDATION AND

VERIFICATION REPORT
HNF-1783

Revision 0

September 27, 1996

\begin{tabular}{|c|c|c|c|c|}
\hline $\begin{array}{l}\text { APPENDIX F } \\
\text { PROCESS/UNIT } \\
\text { PROCESS }\end{array}$ & $\begin{array}{c}\text { APPENDIX C } \\
\text { DATA ELEMENT }\end{array}$ & DISCREPANCY & $\begin{array}{l}\text { RATIONALE FOR } \\
\text { CATEGORY }\end{array}$ & RESOLUTYON \\
\hline $\begin{array}{l}\text { 3.1.8/UP7: Empty drum on } \\
\text { Empty Drum In-feed } \\
\text { Conveyor }\end{array}$ & unclear & $\begin{array}{l}\text { specifies "send process route" - } \\
\text { source unknown: could be } \\
\text { ROUTE_CD, ROUTE_DESCR, } \\
\text { or CONEXT_ROUTE_CD }\end{array}$ & $\begin{array}{l}\text { unit process unclear of source } \\
\text { for data }\end{array}$ & $\begin{array}{l}\text { 1/4/96: Test Proc Review Meet: note } \\
\text { CONEXT_ROUTE_CD in Appendix F } \\
\text { Action Completed and Discrepancy } \\
\text { Item Closed as of } 3 / 6 / 96\end{array}$ \\
\hline \multirow[t]{3}{*}{$\begin{array}{l}\text { 3.1.8/UP15: Drum at TRU } \\
\text { Glovebox Entry Port }\end{array}$} & $\begin{array}{l}\text { Appendix F UP2 specifies } \\
C L \text { message with field } 4 \\
=\text { location and field } 6= \\
\text { no. of containers }\end{array}$ & $\begin{array}{l}\text { UP15 specifies field } 3= \\
\text { TRU_ENTRY (location), field } 4 \\
=1 \text { (no. of containers?) }\end{array}$ & $\begin{array}{l}\text { mismatch between this } \mathrm{CL} \\
\text { instance and the specification } \\
\text { for } \mathrm{Cl} \text { format }\end{array}$ & \multirow[t]{3}{*}{$\begin{array}{l}\text { Phase } 2 / 3 \text { SDD updates to be } \\
\text { addressed as a result of feature } \\
\text { functional specification reviews }\end{array}$} \\
\hline & $\begin{array}{l}\text { UP15 specifies field } 5= \\
\text { CONR_FROM_PKG_ID }\end{array}$ & $\begin{array}{l}\text { field is supposed to display pallet } \\
\text { bin loc }\end{array}$ & \multirow[t]{2}{*}{$\begin{array}{l}\text { mismatch between fields and } \\
\text { data elements }\end{array}$} & \\
\hline & $\begin{array}{l}\text { UP } 15 \text { specifies field } 5 \text { is } \\
\text { set to }=\text { received message } \\
\text { field } 7\end{array}$ & $\begin{array}{l}\text { Appendix F UP2 specification for } \\
\text { CL shows field } 7=\text { PIN - UP15 } \\
\text { specification seems to set pallet } \\
\text { location (field 5) to PIN number }\end{array}$ & & \\
\hline
\end{tabular}




\begin{tabular}{|c|c|c|c|c|}
\hline $\begin{array}{l}\text { APPENDIX F } \\
\text { PROCESS/UNIT } \\
\text { PROCESS }\end{array}$ & $\begin{array}{c}\text { APPENDIX C } \\
\text { DATA ELEMENT }\end{array}$ & DISCREPANCY & $\begin{array}{l}\text { RATIONALE FOR } \\
\text { CATEGORY }\end{array}$ & RESOLUTION \\
\hline $\begin{array}{l}\text { 3.1.8/UP15: Drum at TRU } \\
\text { Glovebox Entry Port } \\
\text { 3.1.8/UP16: Empty } 85- \\
\text { gallon Drum at TRU } \\
\text { Compact Loadout Port } \\
\text { 3.1.8/UP52: Non-Compliant } \\
\text { item and Packet relationship } \\
\text { from PCS }\end{array}$ & PKG_STATUS values & $\begin{array}{l}\text { Appendix } F \text { cites values to be } \\
\text { checked or entered - no permitted } \\
\text { values shown in Appendix } C \text { for } \\
\text { valid entries }\end{array}$ & $\begin{array}{l}\text { data dictionary should } \\
\text { indicate domain of data } \\
\text { element }\end{array}$ & \\
\hline \multirow[t]{2}{*}{$\begin{array}{l}\text { 3.1.8/UP27: Drum stored in } \\
\text { NDE/NDA Carousel }\end{array}$} & PISO_ISO_NAME & $\begin{array}{l}\text { specifies PISO_NAME but } \\
\text { Appendix C has } \\
\text { PISO_ISO_NAME }\end{array}$ & $\begin{array}{l}\text { unclear which is proper data } \\
\text { element name to use - code } \\
\text { needs to be checked against } \\
\text { physical data base and SDD } \\
\text { updated }\end{array}$ & $\begin{array}{l}\text { 1/4/96: Test Proc Review Meet: } \\
\text { change Appendix F to include_ISo_- } \\
\text { Action Completed and Discrepancy } \\
\text { Item Closed as of } 3 / 6 / 96\end{array}$ \\
\hline & PISO_PROF_ID? & $\begin{array}{l}\text { unit process specifies } \\
\text { PISO_PROF_NUM but this is not } \\
\text { found in Appendix C - may be } \\
\text { PISO_PROF_ID }\end{array}$ & $\begin{array}{l}\text { unit process may be using } \\
\text { non-existent data element }\end{array}$ & $\begin{array}{l}\text { 1/4/96: Test Proc Review Meet: } \\
\text { change Appendix F to PROF_ID } \\
\text { Action Completed and Discrepancy } \\
\text { Item Closed as of } 3 / 6 / 96\end{array}$ \\
\hline
\end{tabular}




\begin{tabular}{|c|c|c|c|c|}
\hline $\begin{array}{l}\text { APPENDIX F } \\
\text { PROCESS/UNIT } \\
\text { PROCESS }\end{array}$ & $\begin{array}{c}\text { APPENDIX C } \\
\text { DATA ELEMENT }\end{array}$ & DISCREPANCY & $\begin{array}{l}\text { RATIONALE FOR } \\
\text { CATEGORY }\end{array}$ & RESOLUTION \\
\hline $\begin{array}{l}\text { 3.1.8/UP30: Puck at LLW } \\
\text { Exit Glovebox Puck Receipt } \\
\text { Position }\end{array}$ & \multirow[t]{2}{*}{ unclear } & $\begin{array}{l}\text { specifies LLW puck bar code and } \\
\text { LLW drum PIN - unclear of } \\
\text { source, but may be CON_PKG_ID }\end{array}$ & \multirow[t]{2}{*}{$\begin{array}{l}\text { unit process unclear of source } \\
\text { for data }\end{array}$} & $\begin{array}{l}\text { 1/4/96: Test Proc Review Meet: } \\
\text { change Appendix F to clearly specify } \\
\text { CON_PKG_ID } \\
\text { Action Completed and Discrepancy } \\
\text { Item Closed as of } 3 / 6 / 96\end{array}$ \\
\hline $\begin{array}{l}\text { 3.1.8/UP31: Drum at the } \\
\text { Infeed Conveyor Scale }\end{array}$ & & $\begin{array}{l}\text { cites "PIN and waste data for the } \\
\text { inner waste drum" - unclear of } \\
\text { source, but may be } \\
\text { CONEXT_MAT_GRP_CD }\end{array}$ & & $\begin{array}{l}\text { 1/4/96: Test Proc Review Meet: } \\
\text { change Appendix F to add } \\
\text { CONR_FROM_PKG_ID } \\
\text { Action_Completed and Discrepancy } \\
\text { Item Closed as of } 3 / 6 / 96\end{array}$ \\
\hline \multirow[t]{2}{*}{$\begin{array}{l}\text { 3.1.8/UP32: Drum at the } \\
\text { Infeed Conveyor Scale }\end{array}$} & PISO_ISO_NAME & $\begin{array}{l}\text { specifies PISO_NAME but } \\
\text { Appendix C has } \\
\text { PISO_ISO_NAME }\end{array}$ & $\begin{array}{l}\text { unclear which is proper data } \\
\text { element name to use - code } \\
\text { needs to be checked against } \\
\text { physical data base and SDD } \\
\text { updated }\end{array}$ & $\begin{array}{l}\text { 1/4/96: Test Proc Review Meet: } \\
\text { change Appendix F to include_ISO_- } \\
\text { Action Completed and Discrepancy } \\
\text { Item Closed as of } 3 / 6 / 96\end{array}$ \\
\hline & PISO_PROF_ID & $\begin{array}{l}\text { unit process specifies } \\
\text { PISO_PROF_NUM but this is not } \\
\text { found in Appendix C - may be } \\
\text { PISO_PROF_ID }\end{array}$ & $\begin{array}{l}\text { unit process may be using } \\
\text { non-existent data element }\end{array}$ & $\begin{array}{l}\text { 1/4/96: Test Proc Review Meet: } \\
\text { change Appendix F to PROF_ID } \\
\text { Action Completed and Discrepancy } \\
\text { Item Closed as of 3/6/96 }\end{array}$ \\
\hline
\end{tabular}




\begin{tabular}{|c|c|c|c|c|}
\hline $\begin{array}{l}\text { APPENDIX F } \\
\text { PROCESS/UNIT } \\
\text { PROCESS }\end{array}$ & $\begin{array}{c}\text { APPENDIX C } \\
\text { DATA ELEMENT }\end{array}$ & DISCREPANCY & $\begin{array}{l}\text { RATIONALE FOR } \\
\text { CATEGORY }\end{array}$ & RESOLUTION \\
\hline $\begin{array}{l}\text { 3.1.8/UP35: Drum at } \\
\text { Airlock Conveyor scale, } \\
\text { leaving process area }\end{array}$ & PISO_ISO_NAME & $\begin{array}{l}\text { cites PISO_NAME, but Appendix } \\
C \text { has PISO_ISO_NAME }\end{array}$ & $\begin{array}{l}\text { unclear which is proper data } \\
\text { element name to use - code } \\
\text { needs to be checked against } \\
\text { physical data base and SDD } \\
\text { updated }\end{array}$ & $\begin{array}{l}\text { 1/4/96: Test Proc Review Meet: } \\
\text { change Appendix F to include_ISO_- } \\
\text { Action Completed and Discrepancy } \\
\text { Item Closed as of } 3 / 6 / 96\end{array}$ \\
\hline $\begin{array}{l}\text { 3.1.8/UP36: Drum at } \\
\text { Airlock Conveyor scale }\end{array}$ & PISO_PROF_ID & $\begin{array}{l}\text { unit process specifies } \\
\text { PISO_PROF_NUM - but this is } \\
\text { not found in Appendix C - may be } \\
\text { PISO_PROF_ID }\end{array}$ & $\begin{array}{l}\text { unit process may be using } \\
\text { non-existent data element }\end{array}$ & $\begin{array}{l}\text { 1/4/96: Test Proc Review Meet: } \\
\text { change Appendix F to PROF_ID } \\
\text { Action Completed and Discrepancy } \\
\text { Item Closed as of } 3 / 6 / 96\end{array}$ \\
\hline $\begin{array}{l}\text { 3.1.8/UP38: Drum at } \\
\text { Discharge Conveyor scale }\end{array}$ & CONLOC_LOCN_ID & $\begin{array}{l}\text { cites CONLOC_LOCN but } \\
\text { Appendix C has } \\
\text { CONLOC_LOCN_ID }\end{array}$ & $\begin{array}{l}\text { unclear which is proper data } \\
\text { element name to use - code } \\
\text { needs to be checked against } \\
\text { physical data base and SDD } \\
\text { updated }\end{array}$ & $\begin{array}{l}\text { 1/4/96: Test Proc Review Meet: } \\
\text { change Appendix F to add ID } \\
\text { Action Completed and Discrepancy } \\
\text { Item Closed as of } 3 / 6 / 96\end{array}$ \\
\hline $\begin{array}{l}\text { 3.1.8/UP40: PIN of waste } \\
\text { drum at the LLW or TRU } \\
\text { entry glovebox sent to the } \\
\text { PCS }\end{array}$ & unclear & $\begin{array}{l}\text { cites inner drum IDs and PINs of } \\
\text { non-overpacked drums - unclear of } \\
\text { source: may be } \\
\text { CONR_FROM_PKG_ID and } \\
\text { CONR_TO_PKG_ID- }\end{array}$ & $\begin{array}{l}\text { unit process unclear of source } \\
\text { for data }\end{array}$ & $\begin{array}{l}\text { 1/4/96: Test Proc Review Meet: } \\
\text { message traces back to UP9 - if just a } \\
\text { single PIN, use CON_PKG_ID, } \\
\text { otherwise use CONR_TO_PKG_ID } \\
\text { Discrepancy Item Closed }\end{array}$ \\
\hline
\end{tabular}


WRAP 1 DMS VALIDATION AND

VERIFICATION REPORT
HNF-1783

Revision 0

September 27, 1996

\begin{tabular}{|c|c|c|c|c|}
\hline $\begin{array}{l}\text { APPENDIX F } \\
\text { PROCESS } / \text { UIT } \\
\text { PROCESS }\end{array}$ & $\begin{array}{l}\text { APPENDIX C } \\
\text { DATA ELEMENT }\end{array}$ & DISCREPANCY & $\begin{array}{l}\text { RATIONALE FOR } \\
\text { CATEGORY }\end{array}$ & RESOLUTION \\
\hline $\begin{array}{l}\text { 3.1.8/UP43: Facility Curie } \\
\text { Level to PCS } \\
\text { Message Type: DMSPCS } \\
\text { FCL }\end{array}$ & RADMAT_RAD_TOT & $\begin{array}{l}\text { unit process specifies } \\
\text { RADMAT_RAD_TOTAL, but } \\
\text { Appendix } \bar{C} \text { has } \\
\text { RADMAT_RAD_TOT }\end{array}$ & $\begin{array}{l}\text { unclear which is proper data } \\
\text { element name to use - code } \\
\text { needs to be checked against } \\
\text { physical data base and SDD } \\
\text { updated }\end{array}$ & $\begin{array}{l}\text { 2/20/96: Test Proc. Review Meet: } \\
\text { Appendix C is correct - need to update } \\
\text { Appendix F } \\
\text { Action Completed and Discrepancy } \\
\text { Item Closed as of } 3 / 6 / 96\end{array}$ \\
\hline $\begin{array}{l}\text { 3.1.8/UP46: RW Packet and } \\
\text { Parent Drum relationship } \\
\text { from PCS }\end{array}$ & unclear & $\begin{array}{l}\text { cites location - unclear of source: } \\
\text { may be CONLOC_LOCN_ID. }\end{array}$ & $\begin{array}{l}\text { unit process unclear of source } \\
\text { for data }\end{array}$ & $\begin{array}{l}\text { 1/4/96: Test Proc Review Meet: a } \\
\text { received location from PCS - not } \\
\text { stored in DMS, so no data base } \\
\text { element } \\
\text { Discrepancy Item Closed }\end{array}$ \\
\hline $\begin{array}{l}\text { 3.1.8/UP50: Sample and } \\
\text { Purge Port relationship from } \\
\text { PCS }\end{array}$ & CONEXT_USE_CD? & $\begin{array}{l}\text { specifies value PP - not related to } \\
\text { any particular field - presumed to } \\
\text { be CONEXT_USE_CD }\end{array}$ & $\begin{array}{l}\text { Appendix C should cite } \\
\text { source/data element involved }\end{array}$ & \multirow{2}{*}{$\begin{array}{l}\text { Data contents validated during testing. } \\
\text { Revised data dictionary to be published } \\
\text { as new baseline with "as-built" SDD } \\
\text { revision. Discrepancy Item Closed }\end{array}$} \\
\hline $\begin{array}{l}\text { 3.1.8/UP51: Puck and } \\
\text { Overpack Drum relationship } \\
\text { from PCS }\end{array}$ & $\begin{array}{l}\text { cites update of container } \\
\text { record }\end{array}$ & $\begin{array}{l}\text { unclear: could be WASTE or } \\
\text { WASTEXT table - or record in } \\
\text { other tables? }\end{array}$ & need to clarify affected table & \\
\hline
\end{tabular}




\begin{tabular}{|c|c|c|c|c|}
\hline $\begin{array}{l}\text { APPENDIX F } \\
\text { PROCESS/UNIT } \\
\text { PROCESS } \\
\end{array}$ & $\begin{array}{l}\text { APPENDIX C } \\
\text { DATA ELEMENT }\end{array}$ & DISCREPANCY & $\begin{array}{l}\text { RATIONALE FOR } \\
\text { CATEGORY }\end{array}$ & RESOLUTION \\
\hline $\begin{array}{l}\text { 3.1.8/UP53: Aerosol Can } \\
\text { Collection Container } \\
\text { relationship from PCS }\end{array}$ & $\begin{array}{l}\text { specifies Aerosol Can ID } \\
\text { as being } \\
\text { CONR_FROM_PKG_ID }\end{array}$ & $\begin{array}{l}\text { seems to assign a transport or } \\
\text { product drum ID to a packet } \\
\text { within the drum? }\end{array}$ & $\begin{array}{l}\text { need to verify that cited data } \\
\text { element is correct identifier }\end{array}$ & \\
\hline $\begin{array}{l}\text { 3.1.8/UP54: Removal from } \\
\text { Transfer Stand }\end{array}$ & $\begin{array}{l}\text { specifies number of } \\
\text { packets in transfer drum }\end{array}$ & $\begin{array}{l}\text { not clear - probably a computed } \\
\text { field? }\end{array}$ & $\begin{array}{l}\text { specifications should indicate } \\
\text { data source }\end{array}$ & \\
\hline $\begin{array}{l}\text { 3.1.8/UP54: Removal from } \\
\text { Transfer Stand } \\
\text { 3.1.8/UP55: Added to } \\
\text { Transfer Stand from PCS }\end{array}$ & $\begin{array}{l}\text { specifies RWM Xfer Drum } \\
\text { ID }\end{array}$ & $\begin{array}{l}\text { could be either CON_PKG_ID or } \\
\text { CONEXT_PKG_ID? }\end{array}$ & $\begin{array}{l}\text { unclear which data element is } \\
\text { needed }\end{array}$ & . \\
\hline \multirow[t]{2}{*}{$\begin{array}{l}\text { 3.1.8/UP56: Non-Compliant } \\
\text { Item Presented for } \\
\text { Treatment message from } \\
\text { PCS }\end{array}$} & $\begin{array}{l}\text { specifies LIWWWM } \\
\text { TREATMENT } \\
\text { DESCRIPTION } \\
\end{array}$ & $\begin{array}{l}\text { no data element cited - could be } \\
\text { TREATPROC_DESCR? }\end{array}$ & & \\
\hline & $\begin{array}{l}\text { specifies } \\
\text { WORKSHEET_PKG_ID }\end{array}$ & $\begin{array}{l}\text { no such data element in Appendix } \\
\text { C - should be } \\
\text { WORKITEM_PKG_ID? }\end{array}$ & & . \\
\hline
\end{tabular}


WRAP I DMS VALIDATION AND

VERIFICATION REPORT
HNF-1783

Revision 0

September 27, 1996

\begin{tabular}{|c|c|c|c|c|}
\hline $\begin{array}{l}\text { APPENDIX F } \\
\text { PROCESS/UNIT } \\
\text { PROCESS }\end{array}$ & $\begin{array}{l}\text { APPENDIX C } \\
\text { DATA ELEMENT }\end{array}$ & DISCREPANCY & $\begin{array}{l}\text { RATIONALE FOR } \\
\text { CATEGORY }\end{array}$ & RESOLUTION \\
\hline \multirow[t]{2}{*}{$\begin{array}{l}\text { 3.1.8/UP57: Samples } \\
\text { Presented for Treatment } \\
\text { from PCS }\end{array}$} & $\begin{array}{l}\text { specifies Purge Port } \\
\text { Identification }=\text { to } \\
\text { SAMREL_PKG_ID }\end{array}$ & should be SAMLOC_LOCN_ID? & $\begin{array}{l}\text { apparent mismatch between } \\
\text { specifications and data } \\
\text { element }\end{array}$ & \\
\hline & $\begin{array}{l}\text { specifies RWM Treatment } \\
\text { Location }\end{array}$ & $\begin{array}{l}\text { unclear data source - } \\
\text { CONLOC_LOCN_LD? }\end{array}$ & \multirow[t]{3}{*}{$\begin{array}{l}\text { unclear which data element is } \\
\text { needed }\end{array}$} & \\
\hline $\begin{array}{l}\text { 3.1.8/UP58: Treatment } \\
\text { Container and Item } \\
\text { Container relationship form } \\
\text { PCS } \\
\text { 3.1.8/UP59: Treatment } \\
\text { Container and Loadout } \\
\text { Drum relationship form PCS }\end{array}$ & $\begin{array}{l}\text { cites Location field in the } \\
\text { message }\end{array}$ & $\begin{array}{l}\text { source unclear - could be } \\
\text { CONLOC_LOCN_ID }\end{array}$ & & \\
\hline $\begin{array}{l}\text { 3.1.8UP58: Treatment } \\
\text { Container and Item } \\
\text { Container relationship form } \\
\text { PCS }\end{array}$ & $\begin{array}{l}\text { cites treatment container } \\
\text { field in the message }\end{array}$ & $\begin{array}{l}\text { source unclear - could be } \\
\text { CONR_TO_PKG_ID }\end{array}$ & & \\
\hline
\end{tabular}


WRAP 1 DMS VALIDATION AND

VERIFICATION REPORT
HNF-1783

Revision 0

September 27, 1996

\begin{tabular}{|c|c|c|c|c|}
\hline $\begin{array}{l}\text { APPENDIX F } \\
\text { PROCESS/UNIT } \\
\text { PROCESS }\end{array}$ & $\begin{array}{l}\text { APPENDIX C } \\
\text { DATA ELEMENT }\end{array}$ & DISCREPANCY & $\begin{array}{l}\text { RATIONALE FOR } \\
\text { CATEGORY }\end{array}$ & RESOLUTION \\
\hline $\begin{array}{l}\text { 3.1.8/UP78: SIE Status from } \\
\text { the SIE }\end{array}$ & \multirow[t]{4}{*}{ ERR_NUM } & \multirow{4}{*}{$\begin{array}{l}\text { ERR_NUM? Appendix C only } \\
\text { describes ERRMESSAGE for } \\
\text { SWITS }\end{array}$} & \multirow{4}{*}{$\begin{array}{l}\text { data element and data } \\
\text { ownership rights should be } \\
\text { confirmed to ensure message } \\
\text { is passing correct code }\end{array}$} & \multirow{4}{*}{$\begin{array}{l}\text { 1/18/96: Test Proc Review Meet: } \\
\text { need to update Appendix H to indicate } \\
\text { this is not a SWITS shared table }- \text { see } \\
\text { also: resolution of Category } 1 \\
\text { equipment code discrepancy on } 1 / 4 / 96 \\
\text { Action Completed and Discrepancy } \\
\text { Item Closed as of } 3 / 6 / 96\end{array}$} \\
\hline $\begin{array}{l}3.1 .8 / \text { UP79: SIE status to } \\
\text { the PCS }\end{array}$ & & & & \\
\hline $\begin{array}{l}\text { 3.1.8/UP85: DMS Status to } \\
\text { the PCS }\end{array}$ & & & & \\
\hline $\begin{array}{l}\text { 3.1.8/UP86: PCS Status } \\
\text { from the PCS }\end{array}$ & & & & \\
\hline $\begin{array}{l}\text { 3.1.8/UP92: Drum Database } \\
\text { to SIE }\end{array}$ & unclear & $\begin{array}{l}\text { specifies \% PU-239 - unclear of } \\
\text { source - could be computed? } \\
\text { RAD_QTY? NDA_RATIO? }\end{array}$ & $\begin{array}{l}\text { unit process unclear of source } \\
\text { for data }\end{array}$ & $\begin{array}{l}\text { 1/30/96: Test Proc Review Meet: } \\
\text { division operation and value } \\
\text { content/format need to be confirmed } \\
\text { with SIE and SWITS } \\
\text { Action Completed and Discrepancy } \\
\text { Item Closed as of } 3 / 6 / 96: \text { value } \\
\text { confirmed with vendor }\end{array}$ \\
\hline
\end{tabular}




\begin{tabular}{|c|c|c|c|c|}
\hline $\begin{array}{l}\text { APPENDIX F } \\
\text { PROCESS/UNIT } \\
\text { PROCESS }\end{array}$ & $\begin{array}{c}\text { APPENDIX C } \\
\text { DATA ELEMENT }\end{array}$ & DISCREPANCY & $\begin{array}{l}\text { RATIONALE FOR } \\
\text { CATEGORY }\end{array}$ & RESOLUTION \\
\hline & \multirow[t]{2}{*}{ none } & $\begin{array}{l}\text { specifies CHAD - value: not } \\
\text { specified in Appendix C or G }\end{array}$ & & \multirow{2}{*}{$\begin{array}{l}\text { 1/30/96: Test Proc Review Meet: } \\
\text { CHAD and ABUN are not stored in } \\
\text { DMS } \\
\text { Discrepancy Item Closed }\end{array}$} \\
\hline & & $\begin{array}{l}\text { specifies } A B U N \text { - value: not in } \\
\text { Appendix } C \text { or } G\end{array}$ & & \\
\hline \multirow[t]{3}{*}{$\begin{array}{l}\text { 3.1.8/UP95: Assay results } \\
\text { from SIE }\end{array}$} & \multirow[t]{3}{*}{ NDA/NDAISO } & $\begin{array}{l}\text { specifies NDA_TOT_PU_Cl- } \\
\text { Appendix C has } \\
\text { NDA_TOT_PE_Cl }\end{array}$ & \multirow{3}{*}{$\begin{array}{l}\text { unclear which is proper data } \\
\text { element name to use - name } \\
\text { needs to be checked against } \\
\text { physical data base and SDD } \\
\text { updated }\end{array}$} & \multirow{3}{*}{$\begin{array}{l}\text { 1/30/96: Test Proc Review Meet: } \\
\text { Appendix F contains typos and should } \\
\text { be updated } \\
\text { Action Completed and Discrepancy } \\
\text { Item Closed as of } 3 / 6 / 96\end{array}$} \\
\hline & & $\begin{array}{l}\text { specifies NDA_TMU_PU_CI - } \\
\text { Appendix Chas } \\
\text { NDA_TMU_PE_CI }\end{array}$ & & \\
\hline & & $\begin{array}{l}\text { specifies NDA_THERMAL_ } \\
\text { POWER_TMU - Appendix } \bar{C} \text { has } \\
\text { NDA_TMU_THERMAL_- } \\
\text { POWER }\end{array}$ & & \\
\hline
\end{tabular}




\begin{tabular}{|c|c|c|c|c|}
\hline $\begin{array}{l}\text { APPENDIX F } \\
\text { PROCESS/UNIT } \\
\text { PROCESS }\end{array}$ & $\begin{array}{l}\text { APPENDIX C } \\
\text { DATA ELEMENT }\end{array}$ & DISCREPANCY & $\begin{array}{l}\text { RATIONALE FOR } \\
\text { CATEGORY }\end{array}$ & RESOLUTION \\
\hline \multirow[t]{2}{*}{$\begin{array}{l}\text { 3.1.8 UP96: Non-listed, } \\
\text { long-lived nuclides detected } \\
\text { from SIE }\end{array}$} & MSGLOG & $\begin{array}{l}\text { specifies MSGLOG_INIT_FLAG - } \\
\text { Appendix C has no such data } \\
\text { element }\end{array}$ & $\begin{array}{l}\text { may be trying to access a } \\
\text { non-existent data element }\end{array}$ & $\begin{array}{l}\text { 1/30/96: Test Proc Review Meet: } \\
\text { SCR in place to change "date" to a } \\
\text { flag Comments provided after review } \\
\text { of V\&V discrepancies: Appendix F } \\
\text { teference to MSGLOG should be } \\
\text { deleted } \\
\text { Action Completed and Discrepancy } \\
\text { Item Closed as of } 3 / 6 / 96\end{array}$ \\
\hline & WASTEXT & $\begin{array}{l}\text { specifies CONEXT_NLL } \\
\text { DETECTED - Appendix C has } \\
\text { CONEXT_NLL_DET_- } \\
\text { FLAG }\end{array}$ & $\begin{array}{l}\text { unclear which is proper data } \\
\text { element name to use - name } \\
\text { needs to be checked against } \\
\text { physical data base and SDD } \\
\text { updated }\end{array}$ & $\begin{array}{l}\text { 1/30/96: Test Proc Review Meet: } \\
\text { both Appendix C and F should be } \\
\text { updated - correct data element is now } \\
\text { CONEXT_NLL_DET_DT } \\
\text { Action Completed and Discrepancy } \\
\text { Item Closed as of } 3 / 6 / 96\end{array}$ \\
\hline $\begin{array}{l}\text { 3.1.8/UP99: Assay Results } \\
\text { from BWAS }\end{array}$ & $\begin{array}{l}\text { cites LLW category with } \\
\text { values } 1,3,>3 \text { to set } \\
\text { NDA_WASTE_CAT } \\
\text { values to WC1, WC, and } \\
\text { GTWC3 }\end{array}$ & $\begin{array}{l}\text { NDA_WASTE_CAT values are } 1 \text {, } \\
3,>\overline{3}\end{array}$ & $\begin{array}{l}\text { apparent mismatch between } \\
\text { specified values and } \\
\text { Appendix C domain } \\
\text { definition }\end{array}$ & $\begin{array}{l}\text { Phase } 2 / 3 \text { SDD updates to be } \\
\text { addressed as a result of feature } \\
\text { functional specification reviews }\end{array}$ \\
\hline
\end{tabular}




\begin{tabular}{|c|c|c|c|c|}
\hline $\begin{array}{l}\text { APPENDIX F } \\
\text { PROCESS/UNIT } \\
\text { PROCESS }\end{array}$ & $\begin{array}{c}\text { APPENDIX C } \\
\text { DATA ELEMENT }\end{array}$ & DISCREPANCY & $\begin{array}{l}\text { RATIONALE FOR } \\
\text { CATEGORY }\end{array}$ & RESOLUTION \\
\hline $\begin{array}{l}\text { 3.1.9/UP3-4: User review of } \\
\text { the various assays which } \\
\text { might exist for a single drum } \\
\text { PIN }\end{array}$ & $\begin{array}{l}\text { CONEXT_NLL_DET_ } \\
\text { FLAG? }\end{array}$ & specifies CONEXT_NLLL_DET & \multirow[t]{3}{*}{$\begin{array}{l}\text { unclear which is proper data } \\
\text { element name to use - name } \\
\text { needs to be checked against } \\
\text { physical data base and SDD } \\
\text { updated }\end{array}$} & \multirow[t]{3}{*}{$\begin{array}{l}\text { Comments provided after review or } \\
\text { V\&V discrepancies: Appendix F } \\
\text { should be updated } \\
\text { Action Completed and Discrepancy } \\
\text { Item Closed as of } 3 / 6 / 96\end{array}$} \\
\hline $\begin{array}{l}\text { ACTIVATED FOR WASTE } \\
\text { FORM } \\
\text { 3.1.9 NUP13: User review of } \\
\text { the various assays which } \\
\text { might exist for a single drum }\end{array}$ & NDAISO_QTY_TMU? & specifies NDAISO_TMU & & \\
\hline $\begin{array}{l}\text { 3.1.9/UP5: User selection of } \\
\text { the appropriate product } \\
\text { drum assay to be recorded } \\
\text { as the drum certification }\end{array}$ & ISO_ALPHA_Cl_FACTR? & specifies ISO_ALPHA_FACTR & & \\
\hline
\end{tabular}


WRAP I DMS VALIDATION AND

VERIFICATION REPORT
HNF-1783

Revision 0

September 27, 1996

\begin{tabular}{|c|c|c|c|c|}
\hline $\begin{array}{l}\text { APPENDIX F } \\
\text { PROCESS/UNIT } \\
\text { PROCESS }\end{array}$ & $\begin{array}{c}\text { APPENDIX C } \\
\text { DATA ELEMENT }\end{array}$ & DISCREPANCY & $\begin{array}{l}\text { RATIONALE FOR } \\
\text { CATEGORY }\end{array}$ & RESOLUTYON \\
\hline & RAD_ALPHA_CI? & specifies RAD_ALPHA & & $\begin{array}{l}\text { Revisions to SDD: recent SDD update } \\
\text { shows RAD AlPHA_CI for both } \\
\text { Appendix F and C Discrepancy Item } \\
\text { Closed as of } 3 / 27 / 96\end{array}$ \\
\hline $\begin{array}{l}\text { 3.1.9/UP23: Display of } \\
\text { processed waste drum PINs } \\
\text { for data review }\end{array}$ & unclear & $\begin{array}{l}\text { specifies display of a description } \\
\text { of the type of data error - no } \\
\text { apparent source for storage of } \\
\text {-such errors, except perhaps the } \\
\text { CODECHECK table - no value } \\
\text { domain shown for CODECHECK } \\
\text { in Appendix C }\end{array}$ & $\begin{array}{l}\text { unclear whether data error } \\
\text { types can be displayed }\end{array}$ & $\begin{array}{l}\text { Comments provided after V\&V } \\
\text { Review: local variables only - } \\
\text { dynamically generated - Discrepancy } \\
\text { Item Closed as of } 5 / 17 / 96\end{array}$ \\
\hline $\begin{array}{l}\text { 3.1.9/UP24-25: Update of } \\
\text { container relationships prior } \\
\text { to data review }\end{array}$ & value in CONR_REL_CD & $\begin{array}{l}\text { specifies value of "W" - Appendix } \\
\mathrm{C} \text { domain for CONR_REL_CD } \\
\text { does not contain this value code }\end{array}$ & $\begin{array}{l}\text { unclear if code is correct } \\
\text { and/or will pass validation } \\
\text { checks }\end{array}$ & $\begin{array}{l}\text { Comments provided after review of } \\
\text { V\&V discrepancies: Appendix C } \\
\text { should be updated } \\
\text { Action Completed and Discrepancy } \\
\text { Item Closed as of } 3 / 6 / 96\end{array}$ \\
\hline
\end{tabular}


The following is a supplemental screen comparison which focuses on signature password use. It summarizes Appendix A screens with signature password entry displays as compared to the Appendix F specifications for signature passwords.

\section{ALL ENTRIES IN THIS MATRIX: CATEGORY 2 DISCREPANCIES}

In general, it is difficult to map signature password requirements to the design in Appendix $F$ : it is not clear where passwords are required for data editing or general access. It is also not clear how the screens interact: in many screen hierarchies, signature passwords are required at an upper level screen, but not in lower level screens. Yet Appendix F indicates signature passwords should be required for those screens. This implies that the upper level signature password is being used, but it is not always applicable to the all of the activities for the lower level screen. It appears that a general review should be conducted to validate signature password usage.

\begin{tabular}{|l|l|l|}
\hline $\begin{array}{c}\text { APPENDIX A SCREEN PRINTS: DISPLAY } \\
\text { OF SIGNATURE PASSWORDS }\end{array}$ & $\begin{array}{c}\text { APPENDIX F SPECIFICATIONS FOR } \\
\text { SIGNATURE PASSWORDS }\end{array}$ & RESOLUTION \\
\hline 0101: Container Receiving & $\begin{array}{l}\text { signature password only required when user } \\
\text { selects "Request Cert Data" }\end{array}$ & $\begin{array}{l}\text { 01/30/96: Test Proc Review Meet: SDD general design } \\
\text { specifications paragraph 5.1 requires a general statement: } \\
\text { "For all screens, the term "commit" refers to an ORACLE } \\
\text { commit where data is updated to the data base - in general, } \\
\text { all such commits require signature password." } \\
\text { Accordingly, this screen is specified correctly. }\end{array}$ \\
\hline
\end{tabular}




\begin{tabular}{|c|c|c|}
\hline $\begin{array}{c}\text { ARPENDIX A SCREEN PRINTS; DISPLAY } \\
\text { OF SIGNATURE PASSWORDS }\end{array}$ & $\begin{array}{l}\text { APPENDIX F SPECIFICATIONS FOR } \\
\text { SIGNATURE PASSWORDS }\end{array}$ & RESOLUTION \\
\hline 0201: NDE & $\begin{array}{l}\text { states "User may modify containers at all three } \\
\text { vaults simultaneously, to save } \\
\text { Signature/Password" - no other reference to } \\
\text { signature password mentioned }\end{array}$ & $\begin{array}{l}\text { 01/30/96: Test Proc Review Meet: no signature password } \\
\text { is required - should be removed from Appendix A screen } \\
\text { Action Completed and Discrepancy Item Closed as of } \\
5 / 17 / 96\end{array}$ \\
\hline 0202: NDA & no reference to signature password & $\begin{array}{l}\text { 01/30/96: Test Proc Review Meet: under review - may be } \\
\text { required only to change comments } \\
\text { Follow on comment provided as of } 5 / 17 / 96 \text { : Signature } \\
\text { password should be required for Commit and for Request } \\
\text { Revisit }\end{array}$ \\
\hline 0312: LLW Sorting Table & $\begin{array}{l}\text { requires signature password when user selects } \\
\text { "Commit", "Exit", or "Refresh" }\end{array}$ & \multirow{3}{*}{$\begin{array}{l}\text { 01/30/96: Test Proc Review Meet: SDD general design } \\
\text { specifications paragraph 5.1 requires a general statement: } \\
\text { "For all screens, the term "commit" refers to an ORACLE } \\
\text { commit where data is updated to the data base - in general, } \\
\text { all such commits require signature password." } \\
\text { Accordingly, this screen is specified correctly. }\end{array}$} \\
\hline 0315: LLW Exit Glovebox & $\begin{array}{l}\text { requires signature password when user selects } \\
\text { "Commit", "Exit" }\end{array}$ & \\
\hline 0321: LLW RWM Waste Sorting & $\begin{array}{l}\text { requires signature password when user selects } \\
\text { "Commit" }\end{array}$ & \\
\hline
\end{tabular}




\begin{tabular}{|c|c|c|}
\hline $\begin{array}{l}\text { APPENDIX A SCREEN PRINTS: DISPLAY } \\
\text { OF SIGNATURE PASSWORDS }\end{array}$ & $\begin{array}{l}\text { APPENDIX F SPECIFICATYONS FOR } \\
\text { SIGNATURE PASSWORDS }\end{array}$ & RESOLUTION \\
\hline 0322: LLW RWM Waste Repackaging & $\begin{array}{l}\text { requires signature password when user selects } \\
\text { "Next New Container", "Return to Sorting" }\end{array}$ & $\begin{array}{l}\text { 01/30/96: Test Proc Review Meet: SDD general design } \\
\text { specifications paragraph } 5.1 \text { requires a general statement: } \\
\text { "For all screens, the term "commit" refers to an ORACLE } \\
\text { commit where data is updated to the data base - in general, } \\
\text { all such commits require signature password. "Since the } \\
\text { data base is updated when these buttons are selected, this } \\
\text { screen is specified correctly. }\end{array}$ \\
\hline 0323: LLW RWM Compliant Waste Loädout & $\begin{array}{l}\text { when user selects "Commit", states "Record saved } \\
\text { upon entry of Signature/Password" }\end{array}$ & $\begin{array}{l}\text { 01/30/96: Test Proc Review Meet: SDD general design } \\
\text { specifications paragraph } 5.1 \text { requires a general statement: } \\
\text { "For all screens, the term "commit" refers to an ORACLE } \\
\text { commit where data is updated to the data base - in general, } \\
\text { al such commits require signature password." } \\
\text { Accordingly, this screen is specified correctly. }\end{array}$ \\
\hline 0324: LLW RWM Treatment Item Assembly & $\begin{array}{l}\text { no reference to signature password except when } \\
0326 \text { sub-screen is active }\end{array}$ & \multirow[t]{2}{*}{$\begin{array}{l}\text { 01/30/96: Test Proc Review Meet: to be determined as a } \\
\text { Phase } 2 \text { design issue. }\end{array}$} \\
\hline 0326: LLW RWM Treatment & $\begin{array}{l}\text { when user selects "Commit", states "Record saved } \\
\text { upon entry of Signature/Password" }\end{array}$ & \\
\hline
\end{tabular}




\begin{tabular}{|c|c|c|}
\hline $\begin{array}{l}\text { APPENDIX A SCREEN PRINTS: DISPLAY } \\
\text { OF SIGNATURE PASSWORDS }\end{array}$ & $\begin{array}{l}\text { APPENDLX F SPECIFICATIONS FOR } \\
\text { SIGNATURE PASSWORDS }\end{array}$ & RESOLUTYON \\
\hline 0328: LLW RWM Treated Waste Loadout & $\begin{array}{l}\text { when user selects "Commit", states "Record saved } \\
\text { upon entry of Signature/Password". CHEMCOMP } \\
\text { and PHYSCOMP data also saved. }\end{array}$ & $\begin{array}{l}\text { 01/30/96: Test Proc Review Meet: SDD general design } \\
\text { specifications paragraph } 5.1 \text { requires a general statement: } \\
\text { "For all screens, the term "commit" refers to an ORACLE } \\
\text { commit where data is updated to the data base - in general, } \\
\text { all such commits require signature password." } \\
\text { Accordingly, this screen is specified correctly. }\end{array}$ \\
\hline 0332: TRU Sorting Table & $\begin{array}{l}\text { when user selects "Commit", states "Commit all } \\
\text { data revised on subscreens excluding the Sample } \\
\text { screen DMSS0501 upon signature/password" } \\
\text { not clear how interacts with the signature } \\
\text { password on screen } 0501 \text { - redundant? }\end{array}$ & $\begin{array}{l}\text { 01/30/96: Test Proc Review Meet: to be determined as a } \\
\text { Phase } 3 \text { design issue. }\end{array}$ \\
\hline$* * *$ none on Non-Compliant subscreen & $\begin{array}{l}\text { when user selects "Refresh" from TRU Non- } \\
\text { Compliant Packet Screen, states "Commit data } \\
\text { and regenerate all fields on the screen upon entry } \\
\text { of signature/password." }\end{array}$ & \multirow[t]{2}{*}{$\begin{array}{l}\text { 01/30/96: Test Proc Review Meet: signature password } \\
\text { applies to this subscreen via reference to the parent screen } \\
\text { entry }\end{array}$} \\
\hline *** none on 0334 TRU Physical Components & $\begin{array}{l}\text { when user selects "Commit", states "Save all data } \\
\text { to DMS database upon entry of } \\
\text { signature/password." }\end{array}$ & \\
\hline
\end{tabular}




\begin{tabular}{|c|c|c|}
\hline $\begin{array}{l}\text { APPENDIX A SCREEN PRINTS: DISPLAY } \\
\text { OF SIGNATURE PASSWORDS }\end{array}$ & $\begin{array}{l}\text { APPENDIX F SPECIFICATIONS FOR } \\
\text { SIGNATURE PASSWORDS }\end{array}$ & RESOLUTION \\
\hline $\begin{array}{l}* \text { no screen print - 0341, TRU RWM Waste } \\
\text { Sorting: Phase } 2\end{array}$ & $\begin{array}{l}\text { when user selects "Commit", states } \\
\text { "Signature/Password required" }\end{array}$ & $\begin{array}{l}\text { 01/30/96: Test Proc Review Meet: SDD general design } \\
\text { specifications paragraph } 5.1 \text { requires a general statement: } \\
\text { "For all screens, the term "commit" refers to an ORACLE } \\
\text { commit where data is updated to the data base - in general, } \\
\text { all such commits require signature password." } \\
\text { Accordingly, this screen is specified correctly. }\end{array}$ \\
\hline $\begin{array}{l}* * * \text { no screen print - } 0342 \text {, TRU RWM Separation } \\
\text { of Compliant and Non-Compliant Components: . } \\
\text { Phase } 2\end{array}$ & $\begin{array}{l}\text { when user selects "Next New Container" and } \\
\text { "Return to Sorting", states "Signature/Password } \\
\text { required" }\end{array}$ & $\begin{array}{l}\text { 01/30/96: Test Proc Review Meet: SDD general design } \\
\text { specifications paragraph } 5.1 \text { requires a general statement: } \\
\text { "For all screens, the term "commit" refers to an ORACLE } \\
\text { commit where data is updated to the data base - in general, } \\
\text { all such commits require signature password." Since these } \\
\text { selections generate an update to the database, this screen is } \\
\text { specified correctly. }\end{array}$ \\
\hline $\begin{array}{l}\text { *** no screen print - } 0343 \text {, TRU RWM Compliant } \\
\text { Waste Loadout: Phase } 2\end{array}$ & \multirow[t]{3}{*}{$\begin{array}{l}\text { when user selects "Commit", states "Record saved } \\
\text { upon entry of Signature/Password" }\end{array}$} & \multirow{3}{*}{$\begin{array}{l}\text { 01/30/96: Test Proc Review Meet: SDD general design } \\
\text { specifications paragraph } 5.1 \text { requires a general statement: } \\
\text { "For all screens, the term "commit" refers to an ORACLE } \\
\text { commit where data is updated to the data base - in general, } \\
\text { all such commits require signature password." } \\
\text { Accordingly, this screen is specified correctly. }\end{array}$} \\
\hline $\begin{array}{l}* * * \text { no screen print }-0346, \text { TRU RWM } \\
\text { Treatment: Phase } 2\end{array}$ & & \\
\hline $\begin{array}{l}\text { *** no screen print }-0348, \text { Treated Waste } \\
\text { Loadout Drum Contents: Phase } 2\end{array}$ & & \\
\hline
\end{tabular}




\begin{tabular}{|c|c|c|}
\hline $\begin{array}{l}\text { APPENDIX A SCREEN PRINTS: DISPLAY } \\
\text { OF SIGNATURE PASSWORDS }\end{array}$ & $\begin{array}{l}\text { APPENDIX F SPECIFICATIONS FOR } \\
\text { SIGNATURE PASSWORDS }\end{array}$ & RESOLUTION \\
\hline 0501: Lab Sample Acquisition & $\begin{array}{l}\text { when user selects "Next Sample", states "Commit } \\
\text { currently displayed data upon entry of } \\
\text { signature/password" } \\
\text { when user selects "Analysis Request", states "IF } \\
\text { data has been entered on DMSS0501 screen, } \\
\text { commit data upon entry of signature/password." }\end{array}$ & $\begin{array}{l}\text { 01/30/96: Test Proc Review Meet: to be determined as a } \\
\text { Phase } 2 / 3 \text { design issue. }\end{array}$ \\
\hline $\begin{array}{l}\text { 0502: Chain of Custody (has signature password } \\
\text { for "Relinquished By" and "Received By" }\end{array}$ & $\begin{array}{l}\text { requires entry of signature password in line } 7 \text {, } \\
\text { columns } 1 \text { and } 2 \text { - uses data store COCXFR - } \\
\text { compares the two entries }\end{array}$ & $\begin{array}{l}\text { 01/30/96: Test Proc Review Meet: specification correct - } \\
\text { no update to data base, but comparison is required }\end{array}$ \\
\hline 0503: Field Screening & $\begin{array}{l}\text { states "Return to DMSSOS04 without updating } \\
\text { database or requiring signature/password" }\end{array}$ & $\begin{array}{l}\text { 01/30/96: Test Proc Review Meet: since no data base } \\
\text { commit occurs, specification is correct - signature password } \\
\text { should be removed from Appendix A - Phase } 2 \text { review } \\
\text { activity }\end{array}$ \\
\hline $\begin{array}{l}\text { none on } 0504 \text { Laboratory Sample Analysis Request } \\
\text { screen print }\end{array}$ & $\begin{array}{l}\text { when user selects "Delete Sample", states } \\
\text { "commit data upon entry of signature/password" }\end{array}$ & $\begin{array}{l}\text { 01/30/96: Test Proc Review Meet: SDD general design } \\
\text { specifications paragraph } 5.1 \text { requires a general statement: } \\
\text { "For all screens, the term "commit" refers to an ORACLE } \\
\text { commit where data is updated to the data base - in general, } \\
\text { all such commits require signature password." Since this } \\
\text { selection commits data, this screen is specified correctly. }\end{array}$ \\
\hline
\end{tabular}




\begin{tabular}{|c|c|c|}
\hline $\begin{array}{l}\text { APPENDIX A SCREEN PRINTS: DISPLAY } \\
\text { OF SIGNATURE PASSWORDS }\end{array}$ & $\begin{array}{l}\text { APPENDIX F SPECIFICATIONS FOR } \\
\text { SIGNATURE PASSWORDS }\end{array}$ & RESOLUTION \\
\hline none on 0507 Sample Management/COC & \multirow[t]{2}{*}{$\begin{array}{l}\text { when user selects "Commit", states "No } \\
\text { Signature/Password required" }\end{array}$} & $\begin{array}{l}\text { 01/30/96: Test Proc Review Meet: SDD general design } \\
\text { specifications paragraph } 5.1 \text { requires a general statement: } \\
\text { "For all screens, the term "commit" refers to an ORACLE } \\
\text { commit where data is updated to the data base - in general, } \\
\text { all such commits require signature password." } \\
\text { Accordingly, this screen is specified correctly. }\end{array}$ \\
\hline none on 0509 Sample/Bottle Tracking Data & & \multirow{3}{*}{$\begin{array}{l}\text { 01/30/96: Test Proc Review Meet: validated that this } \\
\text { instance is correct for samples due to the nature of the data } \\
\text { and its placement in the general data base }\end{array}$} \\
\hline none on 0510 Purge Port/Transfer Pig Location & \multirow{2}{*}{$\begin{array}{l}\text { when user selects "Commit", states } \\
\text { "Signature/Password not required" }\end{array}$} & \\
\hline none on 0511 Returned Samples & & \\
\hline none on 0601 Loading Dock Shipping Data & $\begin{array}{l}\text { when user selects "Exit", states "Requests } \\
\text { Signature/Password for Shipping Organization } \\
\text { Representative" }\end{array}$ & $\begin{array}{l}\text { 01/30/96: Test Proc Review Meet: requirement under } \\
\text { review - Phase } 2 \text { review }\end{array}$ \\
\hline \multirow[t]{2}{*}{ 0602: Loading Dock Container Shipping } & $\begin{array}{l}\text { when user selects "Send Shipment Pick List to } \\
\text { PCS", states "Require Signature/Password" }\end{array}$ & $\begin{array}{l}\text { 1/30/96: Test Proc Review Meet: Specification needed; } \\
\text { Appendix F should be updated }\end{array}$ \\
\hline & $\begin{array}{l}\text { as a Trigger for the "In Transit" operation, states } \\
\text { "Requires signature/password to implement this } \\
\text { function" }\end{array}$ & $\begin{array}{l}\text { 1/30/96: Test Proc Review Meet: specification needed; } \\
\text { Appendix F should be updated }\end{array}$ \\
\hline
\end{tabular}




\begin{tabular}{|c|c|c|}
\hline $\begin{array}{l}\text { APPENDIX A SCREEN PRINTS: DISPLAY } \\
\text { OF SIGNATURE PASSWORDS }\end{array}$ & $\begin{array}{l}\text { APPENDIX F SPECIFICATIONS FOR } \\
\text { SIGNATURE PASSWORDS }\end{array}$ & RESOLUTION \\
\hline 0603: TRUPACT Cask Loading/Certification & $\begin{array}{l}\text { when user selects "Commit", states } \\
\text { "Signature/password required" }\end{array}$ & $\begin{array}{l}\text { 01/30/96: Test Proc Review Meet: SDD general design } \\
\text { specifications paragraph } 5.1 \text { requires a general statement: } \\
\text { "For all screens, the term "commit" refers to an ORACLE } \\
\text { commit where data is updated to the data base - in general, } \\
\text { all such commits require signature password," } \\
\text { Accordingly, this screen is specified correctly }\end{array}$ \\
\hline 0902: Process List & $\begin{array}{l}\text { no signature password specified for Shipping } \\
\text { screens }\end{array}$ & $\begin{array}{l}\text { 01/30/96: Test Proc Review Meet: Appendix F } \\
\text { specification is wrong and should be updated }\end{array}$ \\
\hline $\begin{array}{l}\text { none on } 1212 \text { Comparison of Certification and } \\
\text { Verification of DNA Data for newly generated } \\
\text { waste }\end{array}$ & $\begin{array}{l}\text { when user selects "Review Complete", states } \\
\text { "Signature/Password required" }\end{array}$ & $\begin{array}{l}\text { 01/30/96: Test Proc Review Meet: Appendix F } \\
\text { specification is wrong and should be updated Action } \\
\text { Completed and Discrepancy Item Closed as of } 5 / 17 / 96\end{array}$ \\
\hline 1301: Activity Comment & no Appendix $F$ specification for this screen & $\begin{array}{l}\text { 01/30/96: Test Proc Review Meet: Appendix F } \\
\text { specification needs to be added - Phase } 2 \text { review }\end{array}$ \\
\hline
\end{tabular}




\begin{tabular}{|c|c|c|c|c|}
\hline $\begin{array}{l}\text { SCREEN NAVIGATION } \\
\text { and APPENDIX A } \\
\text { SCREENS }\end{array}$ & $\begin{array}{l}\text { APPENDIX } \mathrm{F}, \mathrm{A}, \mathrm{C} \\
\text { CONTENT }\end{array}$ & DISCREPANCY & $\begin{array}{l}\text { RATIONALE } \\
\text { FOR } \\
\text { CATEGORY }\end{array}$ & RESOLUTION \\
\hline \multicolumn{5}{|c|}{ SCREENS: SYSTEM NAVIGATION COMPARED TO APPENDICES F, A, C, and (where applicable), APPENDIX H } \\
\hline \multicolumn{5}{|c|}{ CATEGORY 1 DISCREPANCIES } \\
\hline 0202: NDA & $\begin{array}{l}\text { NDA_PU_FGE, } \\
\text { NDA_PE_CI, } \\
\text { RADDETAIL_PU_FGE, } \\
\text { RADDETAIL_PE_CI }\end{array}$ & $\begin{array}{l}\text { NDA and RADDETAIL } \\
\text { PU_FGE data is being } \\
\text { specified for display in the } \\
\text { PE_Cl field on the screen } \\
\text { - and vice versa }\end{array}$ & $\begin{array}{l}\text { data mapping into } \\
\text { screen display is } \\
\text { reversed }\end{array}$ & $\begin{array}{l}\text { Comments provided after review of V\&V } \\
\text { discrepancies: Appendix F should be updated } \\
\text { Action Completed and Discrepancy Item } \\
\text { Closed as of } 3 / 6 / 96\end{array}$ \\
\hline $\begin{array}{l}\text { Pop-Up: LLW Chemical } \\
\text { Composition }\end{array}$ & $\begin{array}{l}\text { display and allow user to } \\
\text { modify chemical composition } \\
\text { for drum being sorted }\end{array}$ & $\begin{array}{l}\text { Appendix F says to display } \\
\text { PHYS_COMPID - } \\
\text { Appendix C has a PHYS } \\
\text { PKG_ID - no specification } \\
\text { for display of other fields } \\
\text { on screen - no place on } \\
\text { Appendix A screen for } \\
\text { display }\end{array}$ & $\begin{array}{l}\text { screen display may } \\
\text { not be accurate }\end{array}$ & $\begin{array}{l}\text { 1/30/96: Test Proc Review Meet: discrepancy } \\
\text { should actually refer to PHYS_COMP_DESCR } \\
\text { - no display of PKG_ID - Appendix F should } \\
\text { be updated to reflect PHYS_COMP_DESCR } \\
\text { Action Completed and Discrepancy Item } \\
\text { Closed as of } 3 / 6 / 96\end{array}$ \\
\hline
\end{tabular}




\begin{tabular}{|c|c|c|c|c|}
\hline $\begin{array}{l}\text { SCREEN NAVIGATION } \\
\text { and APPENDIX A } \\
\text { SCREENS }\end{array}$ & $\begin{array}{l}\text { APPENDIX F, A, C } \\
\text { CONTENT }\end{array}$ & DISCREPANCY & $\begin{array}{l}\text { RATIONALE } \\
\text { FOR } \\
\text { CATEGORY }\end{array}$ & RESOLUTION \\
\hline $\begin{array}{l}\text { 0321: LLW RWM Waste } \\
\text { Sorting }\end{array}$ & $\begin{array}{l}\text { Appendix } F \text { specifies use of } \\
\text { CON_FROM_PKG_ID to } \\
\text { identify packets }\end{array}$ & $\begin{array}{l}\text { CON_FROM_PKG_ID } \\
\text { seems intended to identify } \\
\text { source drum - perhaps } \\
\text { logic should be to display } \\
\text { CON_PKG_ID where } \\
\text { CON_FROM_PKG_ID is } \\
\text { not null? }\end{array}$ & \multirow[t]{2}{*}{$\begin{array}{l}\text { need to verify data } \\
\text { display to ensure } \\
\text { correct data being } \\
\text { retrieved }\end{array}$} & \multirow[t]{3}{*}{$\begin{array}{l}\text { Phase } 2 / 3 \mathrm{SDD} \text { updates to be addressed as a } \\
\text { result of feature functional specification } \\
\text { reviews }\end{array}$} \\
\hline $\begin{array}{l}\text { 0322: LLW RWM } \\
\text { Repackaging }\end{array}$ & $\begin{array}{l}\text { material group described as } \\
\text { display where MAT_PKG_ID } \\
=\text { CON_PGK_ID }\end{array}$ & $\begin{array}{l}\text { no MAT_PKG_ID in data } \\
\text { dictionary }\end{array}$ & & \\
\hline $\begin{array}{l}\text { 0502: Electronic Chain of } \\
\text { Custody }\end{array}$ & $\begin{array}{l}\text { system navigation states labs } \\
\text { will be treated as a single } \\
\text { custodian for purpose of } \\
\text { WRAP } 1 \text { facility tracking }\end{array}$ & $\begin{array}{l}\text { all } C O C \text { references in } \\
\text { Appendix } F \text { and Appendix } \\
C \text { are for persons - a "lab" } \\
\text { person will have to be } \\
\text { created with all of the } \\
\text { usual person data } \\
\text { elements, and possibly } \\
\text { entered into the PERSON } \\
\text { table }\end{array}$ & $\begin{array}{l}\text { subsequent domain } \\
\text { definitions in } \\
\text { Appendix C should } \\
\text { include this }\end{array}$ & \\
\hline
\end{tabular}




\begin{tabular}{|c|c|c|c|c|}
\hline $\begin{array}{l}\text { SCREEN NAVIGATION } \\
\text { and APPENDIX A } \\
\text { SCREENS }\end{array}$ & $\begin{array}{l}\text { APPENDIX F, A, C } \\
\text { CONTENT }\end{array}$ & DISCREPANCY & $\begin{array}{l}\text { RATIONALE } \\
\text { FOR } \\
\text { CATEGORY }\end{array}$ & RESOLUTION \\
\hline 0505: Worksheet Data Entry & $\begin{array}{l}\text { system navigation specifies } \\
\text { that user is allowed to specify } \\
\text { treatment instructions, and } \\
\text { identity them with a treatment } \\
\text { process number }\end{array}$ & $\begin{array}{l}\text { no edit or amendment of a } \\
\text { worksheet or } \\
\text { assignment/edit of } \\
\text { treatment for a worksheet } \\
\text { is allowed in Appendix } F\end{array}$ & $\begin{array}{l}\text { either wording in } \\
\text { system navigation } \\
\text { is incorrect, or } \\
\text { design functionality } \\
\text { is incorrect }\end{array}$ & $\begin{array}{l}\text { Screen navigation specifications to be finalized } \\
\text { as a result of Phase } 2 / 3 \text { functional specification } \\
\text { reviews }\end{array}$ \\
\hline 0509: Sample/Bottle Tracking & $\begin{array}{l}\text { Appendix A screen print } \\
\text { shows a display of a } \\
\text { comments field }\end{array}$ & $\begin{array}{l}\text { no Appendix } F \text { data } \\
\text { element mapping specified } \\
\text { for comments }\end{array}$ & $\begin{array}{l}\text { design may not be } \\
\text { supporting required } \\
\text { data display }\end{array}$ & $\begin{array}{l}\text { Phase } 2 / 3 \text { SDD updates to be addressed as a } \\
\text { result of feature functional specification } \\
\text { reviews }\end{array}$ \\
\hline Shipping Menu & $\begin{array}{l}\text { TRUPACT shipping } \\
\text { documentation required }\end{array}$ & $\begin{array}{l}\text { none specified: deferred } \\
\text { until later phases }\end{array}$ & $\begin{array}{l}\text { design needs update } \\
\text { for this } \\
\text { functionality }\end{array}$ & \multirow[t]{2}{*}{$\begin{array}{l}\text { Screen navigation specifications to be finalized } \\
\text { as a result of Phase } 2 / 3 \text { functional specification } \\
\text { reviews }\end{array}$} \\
\hline $\begin{array}{l}\text { 0601: Loading Dock Shipping } \\
\text { Data: user allowed to reroute } \\
\text { drums back through the } \\
\text { process to collect missing data }\end{array}$ & $\begin{array}{l}\text { IN_TRANSIT button not } \\
\text { enabled until all WRAP } \\
\text { locations listed as SHIPDCK } \\
\text { - other displays curtailed or } \\
\text { indicating missing data }\end{array}$ & $\begin{array}{l}\text { however, no provision for } \\
\text { reprocessing or } \\
\text { specification on how } \\
\text { problems to be corrected }\end{array}$ & $\begin{array}{l}\text { specification does } \\
\text { not appear to } \\
\text { support processing } \\
\text { described in screen } \\
\text { navigation }\end{array}$ & \\
\hline
\end{tabular}




\begin{tabular}{|c|c|c|c|c|}
\hline $\begin{array}{c}\text { SCREEN NAVIGATION } \\
\text { and APPENDIX A } \\
\text { SCREENS }\end{array}$ & $\begin{array}{l}\text { APPENDIX F, A, C } \\
\text { CONTENT }\end{array}$ & DISCREPANCY & $\begin{array}{l}\text { RATIONALE } \\
\text { FOR } \\
\text { CATEGORY }\end{array}$ & RESOLUTION \\
\hline $\begin{array}{l}\text { 0603: TRUPACT Cask } \\
\text { Loading/ } \\
\text { Certification: screen printed } \\
\text { and taken to TRUPACT } \\
\text { loading bay where data will be } \\
\text { manually recorded on the } \\
\text { screen print }\end{array}$ & \multirow[t]{2}{*}{ none } & $\begin{array}{l}\text { no print button specified to } \\
\text { generate this hard copy }\end{array}$ & $\begin{array}{l}\text { cannot support } \\
\text { processing as } \\
\text { described in screen } \\
\text { navigation }\end{array}$ & \\
\hline $\begin{array}{l}\text { 0604: TRUPACT Shipping } \\
\text { Documentation - allow user to } \\
\text { print the applicable } \\
\text { TRUPACT shipping } \\
\text { documentation to support } \\
\text { shipment of TRUPACTS from } \\
\text { WRAP } 1 \text { facility }\end{array}$ & & $\begin{array}{l}\text { screen not specified in } \\
\text { Appendix } C \text { or } F \text { - no } \\
\text { specification for including } \\
\text { it on the Shipping Menu }\end{array}$ & $\begin{array}{l}\text { specifications not } \\
\text { complete - may be } \\
\text { deferred to a later } \\
\text { phase? }\end{array}$ & . \\
\hline 0701: Error Message Table & ERRMESSAGE tabie & $\begin{array}{l}\text { Appendix } H \text { indicates } \\
\text { ERRMESSAGE is shared } \\
\text { with SWITS and under } \\
\text { joint configuration control }\end{array}$ & $\begin{array}{l}\text { all other SWITS } \\
\text { shared tables have } \\
\text { been omitted from } \\
\text { SDD screen specs - } \\
\text { this may not be a } \\
\text { DMS-updated table }\end{array}$ & $\begin{array}{l}\text { 1/18/96: Test Proc Review Meet: need to } \\
\text { update Appendix } \mathrm{H} \text { to indicate this is not a } \\
\text { sWITS shared table } \\
\text { Action Completed and Discrepancy Item } \\
\text { Closed as of } 3 / 6 / 96\end{array}$ \\
\hline
\end{tabular}




\begin{tabular}{|c|c|c|c|c|}
\hline $\begin{array}{l}\text { SCREEN NAVIGATION } \\
\text { and APPENDIX A } \\
\text { SCREENS } \\
\end{array}$ & $\begin{array}{l}\text { APPENDIX F, A, C } \\
\text { CONTENT }\end{array}$ & DISCREPANCY & $\begin{array}{l}\text { RATIONALE } \\
\text { FOR } \\
\text { CATEGORY }\end{array}$ & RESOLUTION \\
\hline 0702: User Table & USER table & $\begin{array}{l}\text { Appendix C } \\
\text { USR USERID described } \\
\text { as ID of a SWITS user - } \\
\text { edited in DMS? }\end{array}$ & $\begin{array}{l}\text { should validate that } \\
\text { this is a DMS- } \\
\text { updated field }\end{array}$ & $\begin{array}{l}\text { 1/18/96: Test Proc Review Meet: need to } \\
\text { change Appendix C - not a SWITS user ID } \\
\text { Action Completed and Discrepancy Item } \\
\text { Closed as of } 3 / 6 / 96\end{array}$ \\
\hline 0705: System Bulletin & SYSBUL table & $\begin{array}{l}\text { table exists in Appendix C } \\
\text { but Appendix A does not } \\
\text { specify screen }\end{array}$ & $\begin{array}{l}\text { may be missing a } \\
\text { table that needs } \\
\text { updating }\end{array}$ & $\begin{array}{l}\text { 1/18/96: Test Proc Review Meet: "defunct" } \\
\text { table - need to delete it from the physical data } \\
\text { base and update Appendix C } \\
\text { Action Completed and Discrepancy Item } \\
\text { Closed as of } 3 / 6 / 96\end{array}$ \\
\hline New 0705: Report Table & REPORTABLE & $\begin{array}{l}\text { new maintenance screen } \\
\text { added to latest version of } \\
\text { SDD - no screen print } \\
\text { available }\end{array}$ & $\begin{array}{l}\text { unable to validate } \\
\text { screen }\end{array}$ & $\begin{array}{l}\text { Screen navigation specifications to be finalized } \\
\text { as a result of Phase } 2 / 3 \text { functional specification } \\
\text { reviews }\end{array}$ \\
\hline 0708: User Role Table & USERROLE table? & $\begin{array}{l}\text { no description field } \\
\text { described in Appendix C }\end{array}$ & $\begin{array}{l}\text { may be trying to } \\
\text { edit/update a non- } \\
\text { existent field }\end{array}$ & $\begin{array}{l}\text { 1/18/96: Test Proc Review Meet: field is } \\
\text { pulled from the ROLE table for display on this } \\
\text { screen } \\
\text { Discrepancy Item Closed }\end{array}$ \\
\hline 0710: Field Help Table & DATADICT & $\begin{array}{l}\text { listed in latest version of } \\
\text { SDD as a SWITS lookup } \\
\text { table }\end{array}$ & $\begin{array}{l}\text { should be } \\
\text { maintained in } \\
\text { SWITS }\end{array}$ & $\begin{array}{l}\text { Phase } 2 / 3 \text { SDD updates to be addressed as a } \\
\text { result of feature functional specification } \\
\text { reviews }\end{array}$ \\
\hline
\end{tabular}




\begin{tabular}{|c|c|c|c|c|}
\hline $\begin{array}{l}\text { SCREEN NAVIGATION } \\
\text { and APPENDIX A } \\
\text { SCREENS }\end{array}$ & $\begin{array}{l}\text { APPENDIX F, A, C } \\
\text { CONTENT }\end{array}$ & DISCREPANCY & $\begin{array}{l}\text { RATIONALE } \\
\text { FOR } \\
\text { CATEGORY } \\
\end{array}$ & RESOLUTION \\
\hline \multirow[t]{2}{*}{$\begin{array}{l}\text { 0712: New User Setup (listed } \\
\text { in System Navigation Only) }\end{array}$} & USER table & $\begin{array}{l}\text { no screen specified in } \\
\text { Appendix A - unclear if } \\
\text { some fields being updated } \\
\text { from other screens }\end{array}$ & $\begin{array}{l}\text { no apparent screen } \\
\text { to } \\
\text { add/change/delete } \\
\text { users - unclear if } \\
\text { this is performed } \\
\text { via other tables }\end{array}$ & $\begin{array}{l}\text { 1/18/96: Test Proc Review Meet: new users } \\
\text { now maintained through screen } 0708 \text { - need to } \\
\text { update SDD to remove screen from System } \\
\text { Navigation paragraphs } \\
\text { Action Completed and Discrepancy Item } \\
\text { Closed as of } 3 / 6 / 96\end{array}$ \\
\hline & PERSON table & $\begin{array}{l}\text { PERSON is listed in } \\
\text { Appendix } \mathrm{H} \text { as being } \\
\text { under joint configuration } \\
\text { control }\end{array}$ & $\begin{array}{l}\text { should validate that } \\
\text { this is a DMS- } \\
\text { updated table }\end{array}$ & $\begin{array}{l}\text { 1/18/96: Test Proc Review Meet: see above - } \\
\text { no screen - see screen } 0702 \text { above discussion } \\
\text { regarding PERSON table } \\
\text { Action Completed and Discrepancy Item } \\
\text { Closed as of } 3 / 6 / 96\end{array}$ \\
\hline
\end{tabular}




\begin{tabular}{|l|l|l|l|l|}
\hline $\begin{array}{c}\text { SCREEN NAVIGATION } \\
\text { and APPENDIX A } \\
\text { SCREENS }\end{array}$ & $\begin{array}{c}\text { APPENDIX F, A, C } \\
\text { CONTENT }\end{array}$ & DISCREPANCY & $\begin{array}{c}\text { RATIONALE } \\
\text { FOR } \\
\text { CATEGORY }\end{array}$ & RESOLUTION \\
\hline none & $\begin{array}{l}\text { COMMUNICATION } \\
\text { TABLE table } \\
\text { SECURTY table } \\
\text { USERSIGNPASS table }\end{array}$ & $\begin{array}{l}\text { no screens defined for } \\
\text { maintenance of these tables } \\
\text { which are in Appendix C }\end{array}$ & $\begin{array}{l}\text { mables that need } \\
\text { editing }\end{array}$ & $\begin{array}{l}\text { 1/18/96: Test Proc Review Meet: } \\
\text { COMMUNICATION } \\
\text { TABLE is a "mailbox" no lookup/validation - } \\
\text { SECURITY table should be deleted from } \\
\text { Appendix C because it has been deleted from } \\
\text { design - } \\
\text { Action Completed and Discrepancy Item } \\
\text { Closed as of 3/6/96 }\end{array}$ \\
\hline $\begin{array}{l}\text { USERSIGNPASS maintenance has no } \\
\text { resolution in Phase 1 -not defined yet because } \\
\text { procedures regarding assignment and } \\
\text { maintenance of these are not defined--To be } \\
\text { addressed during Phase 2/3 functional } \\
\text { specification reviews }\end{array}$ \\
\hline
\end{tabular}




\begin{tabular}{|c|c|c|c|c|}
\hline $\begin{array}{l}\text { SCREEN NAVIGATION } \\
\text { and APPENDIX A } \\
\text { SCREENS }\end{array}$ & $\begin{array}{l}\text { APPENDIX F, A, C } \\
\text { CONTENT }\end{array}$ & DISCREPANCY & $\begin{array}{l}\text { RATIONALE } \\
\text { FOR } \\
\text { CATEGORY }\end{array}$ & RESOLUTION \\
\hline $\begin{array}{l}\text { 1201: Processed Waste NDA } \\
\text { Data Review and Modification }\end{array}$ & $\begin{array}{l}\text { user reviews NDA data } \\
\text { associated with waste drums } \\
\text { which are processed in } \\
\text { WRAP } 1 \text { - Appendix F UP1 } \\
\text { has several buttons used to } \\
\text { display specific data } \\
\text { categories }\end{array}$ & \multirow{3}{*}{$\begin{array}{l}\text { screen print has data which } \\
\text { is not specified in } \\
\text { Appendix F - no } \\
\text { specification for display } \\
\text { of: Total Isotopic Records, } \\
\text { Thermal Power, Waste } \\
\text { Category, Total Alpha Ci, } \\
\text { TMU Alpha Ci, Sec Waste } \\
\text { Type, NLLL Detected, } \\
\text { Total PE Ci, TMU PE Ci, } \\
\text { Profile, Revisit, Profile } \\
\text { ID, Future Eval Required, } \\
\text { Total PE FGE, TMU PE } \\
\text { FGE }\end{array}$} & \multirow[t]{3}{*}{$\begin{array}{l}\text { unclear how large } \\
\text { portion of screen to } \\
\text { be generated - } \\
\text { screen design seems } \\
\text { to be significantly } \\
\text { in excess of screen } \\
\text { specification }\end{array}$} & \multirow[t]{3}{*}{$\begin{array}{l}\text { Comments provided after review of V\&V } \\
\text { discrepancies: screen reviews have defined } \\
\text { actual data to display on these screens - SDD } \\
\text { "as built" updates reflect new requirements to } \\
\text { display data from NDA, NDAISO tables - } \\
\text { Action Completed and Discrepancy Item } \\
\text { Closed as of } 3 / 6 / 96\end{array}$} \\
\hline $\begin{array}{l}\text { 1202: Compacted Drum NDA } \\
\text { Data Review }\end{array}$ & $\begin{array}{l}\text { user reviews NDA data } \\
\text { associated with individual } \\
\text { waste pucks which comprise } \\
\text { a product drum generated in } \\
\text { process area LLW Glovebox }\end{array}$ & & & \\
\hline $\begin{array}{l}\text { 1211: Verification NDA Data } \\
\text { Review }\end{array}$ & $\begin{array}{l}\text { user reviews NDA data } \\
\text { associated with waste drums } \\
\text { which are not processed in } \\
\text { WRAP facility }\end{array}$ & & & \\
\hline $\begin{array}{l}\text { 1231: Verification Data } \\
\text { Review Waste Compliant }\end{array}$ & $\begin{array}{l}\text { allow the user to review and } \\
\text { modify data for a specific } \\
\text { drum that has only undergone } \\
\text { NDE and NDA exams in } \\
\text { WRAP - allow modification } \\
\text { of WRAP generated data }\end{array}$ & $\begin{array}{l}\text { no screen specifications or } \\
\text { screen print in Appendix A } \\
\text { - unable to validate screen } \\
\text { against Appendix F } \\
\text { specifications }\end{array}$ & $\begin{array}{l}\text { screen missing or } \\
\text { deferred to later } \\
\text { development }\end{array}$ & $\begin{array}{l}\text { Comments provided after review of V\&V } \\
\text { discrepancies: Appendix A should be updated } \\
\text { Action Completed and Discrepancy Item } \\
\text { Closed as of } 3 / 6 / 96\end{array}$ \\
\hline
\end{tabular}




\begin{tabular}{||l|l|l|l|l|}
\hline $\begin{array}{c}\text { SCREEN NAVIGATION } \\
\text { and APPENDIX A } \\
\text { SCREENS }\end{array}$ & $\begin{array}{c}\text { APPENDIX F, A, C } \\
\text { CONTENT }\end{array}$ & DISCREPANCY & $\begin{array}{c}\text { RATIONALE } \\
\text { FOR } \\
\text { CATEGORY }\end{array}$ & RESOLUTION \\
\hline \multicolumn{2}{|c|}{ CATEGORY 2 DISCREPANCIES } \\
\hline $\begin{array}{l}\text { WRAP 1 DMS User Menu: } \\
\text { NDE/NDA Operations }\end{array}$ & $\begin{array}{l}\text { Appendix F implies there are } \\
\text { two different selections for } \\
\text { DMSS0201 and 0202 }\end{array}$ & $\begin{array}{l}\text { screen print only shows } \\
\text { one screen selection for } \\
\text { both }\end{array}$ & $\begin{array}{l}\text { may be requiring } \\
\text { an undesirable } \\
\text { menu "branch" to } \\
\text { activate operations } \\
\text { that should be } \\
\text { accessed directly }\end{array}$ & $\begin{array}{l}\text { 1/30/96: Test Proc Review Meet: menu } \\
\text { selection actually creates a ment pull down } \\
\text { with multiple choices - screen print is correct - } \\
\text { Appendix A screens in the SDD } \\
\text { Action taken in Rev 2 of SDD - Discrepancy } \\
\text { Item Closed as of 5/17/96 }\end{array}$ \\
\hline
\end{tabular}




\begin{tabular}{|c|c|c|c|c|}
\hline $\begin{array}{l}\text { SCREEN NAVIGATION } \\
\text { and APPENDIX A } \\
\text { SCREENS }\end{array}$ & $\begin{array}{l}\text { APPENDIX F, A, C } \\
\text { CONTENT }\end{array}$ & DISCREPANCY & $\begin{array}{l}\text { RATIONALE } \\
\text { FOR } \\
\text { CATEGORY }\end{array}$ & RESOLUTION \\
\hline $\begin{array}{l}\text { WRAP } 1 \text { DMS User Menu: } \\
\text { Process (Glovebox) } \\
\text { Operations }\end{array}$ & $\begin{array}{l}\text { Appendix A shows Process } \\
\text { Ops }\end{array}$ & $\begin{array}{l}\text { in Appendix F the } \\
\text { following operations start } \\
\text { by selecting a lower } \\
\text { hierarchy menu - not clear } \\
\text { if this is supposed to be a } \\
\text { submenu under the Process } \\
\text { Ops selection on the Main } \\
\text { Menu - for all, when user } \\
\text { selects Exit, returns to } \\
\text { Main Menu: } \\
\text { 3.1.3.1 - UP1: request } \\
\text { DMSSO311 from LLW } \\
\text { Process Menu } \\
\text { 3.1.3.2 - UP1: request } \\
\text { DMSSO321 from LLW } \\
\text { RWM Process Menu } \\
\text { 3.1.3.3 - UP1: request } \\
\text { DMSS0331 from TRU } \\
\text { Glovebox Menu } \\
\text { 3.1.3.4 - UP2: request } \\
\text { DMSS0341 from TRU }\end{array}$ & $\begin{array}{l}\text { screen hierarchy } \\
\text { should be verified }\end{array}$ & $\begin{array}{l}\text { 1/30/96: Test Proc Review Meet: screen } \\
\text { hierarchy is shrown in Fig 5-1 in a later } \\
\text { revision of the SDD - not available for V\&V at } \\
\text { time of analysis - screen operation is validated } \\
\text { as correctly stated in Appendix F } \\
\text { Discrepancy Item Closed }\end{array}$ \\
\hline
\end{tabular}




\begin{tabular}{|c|c|c|c|c|}
\hline $\begin{array}{l}\text { SCREEN NAVIGATION } \\
\text { and APPENDIX A } \\
\text { SCREENS }\end{array}$ & $\begin{array}{l}\text { APPENDIX F, A, C } \\
\text { CONTENT }\end{array}$ & DISCREPANCY & $\begin{array}{l}\text { RATIONALE } \\
\text { FOR } \\
\text { CATEGORY } \\
\end{array}$ & RESOLUTION \\
\hline $\begin{array}{l}\text { WRAP } 1 \text { DMS User Menu: } \\
\text { Table Maintenance }\end{array}$ & $\begin{array}{l}\text { Appendix A shows Table } \\
\text { Maint }\end{array}$ & $\begin{array}{l}\text { no specification in } \\
\text { Appendix } F\end{array}$ & $\begin{array}{l}\text { design } \\
\text { specifications are } \\
\text { not available }\end{array}$ & $\begin{array}{l}\text { 1/30/96: Test Proc Review Meet: design will } \\
\text { be incorporated into O\&M Manual } \\
\text { Discrepancy Item Closed for WHC }\end{array}$ \\
\hline $\begin{array}{l}\text { WRAP } 1 \text { DMS User Menu: } \\
\text { Sample Management }\end{array}$ & $\begin{array}{l}\text { Appendix A shows Sample } \\
\text { Mgmt }\end{array}$ & $\begin{array}{l}\text { 3.1.4 - UP1: specifies } \\
\text { selection of sample } \\
\text { management from } \\
\text { DMSS0312, DMSS0322, } \\
\text { DMSS0332, DMSS0342 - } \\
\text { no mention of Main Menu } \\
\text { for selection - however } \\
\text { Exit returns to Main Menu }\end{array}$ & \multirow[t]{3}{*}{$\begin{array}{l}\text { screen hierarchy } \\
\text { should be verified }\end{array}$} & $\begin{array}{l}\text { 1/30/96: Test Proc Review Meet: Appendix F } \\
\text { should be updated } \\
\text { Corrected in Rev } 2 \text { of SDD - Action } \\
\text { Completed and Discrepancy Item Closed as } \\
\text { of } 5 / 17 / 96\end{array}$ \\
\hline $\begin{array}{l}\text { App F: 3.1.4/UP25 specifies } \\
\text { selection of DMSS0510 from } \\
\text { Main Menu }\end{array}$ & \multirow[t]{2}{*}{ apparent submenu selection } & $\begin{array}{l}\text { should be submenu under } \\
\text { Sample Management? }\end{array}$ & & \multirow{2}{*}{$\begin{array}{l}\text { 1/30/96: Test Proc Review Meet: Appendix A } \\
\text { should be updated to include screen hierarchy } \\
\text { Action Completed and Discrepancy Item } \\
\text { Closed as of } 3 / 6 / 96\end{array}$} \\
\hline $\begin{array}{l}\text { App F: 3.1.4/UP26 specifies } \\
\text { selection of DMSS0511 from } \\
\text { Main Menu }\end{array}$ & & $\begin{array}{l}\text { should be submenu under } \\
\text { Sample Management? }\end{array}$ & & \\
\hline
\end{tabular}




\begin{tabular}{|c|c|c|c|c|}
\hline $\begin{array}{l}\text { SCREEN NAVIGATION } \\
\text { and APPENDIX A } \\
\text { SCREENS }\end{array}$ & $\begin{array}{l}\text { APPENDIX F, A, C } \\
\text { CONTENT }\end{array}$ & DISCREPANCY & $\begin{array}{l}\text { RATIONALE } \\
\text { FOR } \\
\text { CATEGORY }\end{array}$ & RESOLUTION \\
\hline $\begin{array}{l}\text { WRAP } 1 \text { DMS User Menu: } \\
\text { Shipping }\end{array}$ & Appendix A shows Shipping & $\begin{array}{l}\text { DMSS0601 - no mention } \\
\text { of Main Menu in } \\
\text { Appendix F for selection - } \\
\text { however Exit from } \\
\text { DMSS0603 retums to } \\
\text { Main Menu }\end{array}$ & & Appendix $F$ should be updated \\
\hline $\begin{array}{l}\text { WRAP } 1 \text { DMS User Menu: } \\
\text { System Administration }\end{array}$ & Appendix A shows Admin & $\begin{array}{l}\text { no Appendix } F \\
\text { specifications for System } \\
\text { Administration }\end{array}$ & $\begin{array}{l}\text { developer does not } \\
\text { have approved } \\
\text { specifications to } \\
\text { work from }\end{array}$ & $\begin{array}{l}\text { 1/30/96: Test Proc Review Meet: Appendix F } \\
\text { should be updated Comments provided after } \\
\text { review of V\&V discrepancies: system } \\
\text { administrative procedures. will be defined in the } \\
\text { O\&M manual and the System Administration } \\
\text { Manual when they are published }\end{array}$ \\
\hline $\begin{array}{l}\text { WRAP I DMS User Menu: } \\
\text { Reports }\end{array}$ & Appendix A shows Reports & $\begin{array}{l}\text { no Appendix } F \\
\text { specifications for Reports }\end{array}$ & $\begin{array}{l}\text { unclear how reports } \\
\text { will be developed }\end{array}$ & $\begin{array}{l}\text { 1/30/96: Test Proc Review Meet: Appendix B } \\
\text { is considered to contain report specifications - } \\
\text { actual screen mechanism for selecting and } \\
\text { producing reports is to be addressed in Phase } 2\end{array}$ \\
\hline $\begin{array}{l}\text { WRAP } 1 \text { DMS User Menu: } \\
\text { Pick List }\end{array}$ & Appendix A shows Pick List & $\begin{array}{l}\text { DMSS0901 - no mention } \\
\text { of Main Menu in } \\
\text { Appendix F for selection - } \\
\text { however Exit returns to } \\
\text { Main Menu }\end{array}$ & $\begin{array}{l}\text { screen hierarchy } \\
\text { should be verified }\end{array}$ & $\begin{array}{l}\text { 1/30/96: Test Proc Review Meet: Appendix A } \\
\text { should be updated with new screen hierarchy } \\
\text { Action Completed and Discrepancy Item } \\
\text { Closed as of } 3 / 6 / 96\end{array}$ \\
\hline
\end{tabular}




\begin{tabular}{|c|c|c|c|c|}
\hline $\begin{array}{l}\text { SCREEN NAVIGATION } \\
\text { and APPENDIX A } \\
\text { SCREENS }\end{array}$ & $\begin{array}{l}\text { APPENDIX F, A, C } \\
\text { CONTENT }\end{array}$ & DISCREPANCX & $\begin{array}{l}\text { RATIONALE } \\
\text { FOR } \\
\text { CATEGORY } \\
\end{array}$ & RESOLUTION \\
\hline $\begin{array}{l}\text { WRAP } 1 \text { DMS User Menu: } \\
\text { Activity Comment }\end{array}$ & none & no specification & $\begin{array}{l}\text { not clear if this is a } \\
\text { needed Main Menu } \\
\text { feature }\end{array}$ & $\begin{array}{l}\text { 1/30/96: Test Proc Review Meet: screen is } \\
\text { required as shown in Appendix A - Appendix F } \\
\text { should be updated Action Completed and } \\
\text { Discrepancy Item Closed as of } 3 / 6 / 96\end{array}$ \\
\hline none & Appendix A shows Edit & & $\begin{array}{l}\text { unclear of the } \\
\text { intention of this } \\
\text { selection }\end{array}$ & $\begin{array}{l}\text { 1/30/96: Test Proc Review Meet: refers to } \\
\text { Windows "clipboatd" feature - not a DMS } \\
\text { application development } \\
\text { Discrepancy Item Closed }\end{array}$ \\
\hline $\begin{array}{l}\text { 0102: Bar Code Package ID } \\
\text { Labels }\end{array}$ & $\begin{array}{l}\text { available as a screen selection } \\
\text { from DMSS0101 }\end{array}$ & $\begin{array}{l}\text { specified to be a screen } \\
\text { selection from DMSS0101 } \\
\text { and } 0102 \text {, but no selection } \\
\text { shown on Appendix A }\end{array}$ & $\begin{array}{l}\text { screen hierarchy } \\
\text { should be verified }\end{array}$ & $\begin{array}{l}\text { 1/30/96: Test Proc Review Meet: Appendix A } \\
\text { should be updated - labels menu on Main Menu } \\
\text { is correct } \\
\text { Action Completed and Discrepancy Item } \\
\text { Closed as of } 3 / 6 / 96\end{array}$ \\
\hline 0201: NDE & $\begin{array}{l}\text { Appendix F describes pop-up } \\
\text { screens for display of Waste } \\
\text { Record, Phys Comp, Rad } \\
\text { Detail buttons }\end{array}$ & $\begin{array}{l}\text { Appendix A has no pop-up } \\
\text { displays for these } \\
\text { selections }\end{array}$ & $\begin{array}{l}\text { cannot verify how } \\
\text { Appendix F } \\
\text { compares to screen } \\
\text { content }\end{array}$ & $\begin{array}{l}\text { Comments provided after review of V\&V } \\
\text { discrepancies: displays are for individual } \\
\text { database records as selected from the Appendix } \\
\text { F buttons } \\
\text { Action Completed and Discrepancy Item } \\
\text { Closed as of } 3 / 6 / 96\end{array}$ \\
\hline
\end{tabular}




\begin{tabular}{|c|c|c|c|c|}
\hline $\begin{array}{l}\text { SCREEN NAVIGATION } \\
\text { and APPENDIX A } \\
\text { SCREENS }\end{array}$ & $\begin{array}{l}\text { APPENDIX F, A, C } \\
\text { CONTENT }\end{array}$ & DISCREPANCY & $\begin{array}{l}\text { RATIONALE } \\
\text { FOR } \\
\text { CATEGORY }\end{array}$ & RESOLUTION \\
\hline 0312: LLW Sorting Table & $\begin{array}{l}\text { provide user with information } \\
\text { necessary for separating } \\
\text { compliant and non-compliant } \\
\text { waste }\end{array}$ & $\begin{array}{l}\text { Appendix F specifies } \\
\text { selection from 0311 - } \\
\text { actual screen to select } \\
\text { from is contradictory } \\
\text { between App F and } \\
\text { System Nav }\end{array}$ & $\begin{array}{l}\text { screen hierarchy } \\
\text { may not be correct }\end{array}$ & $\begin{array}{l}\text { 1/30/96: Test Proc Review Meet: Update } \\
\text { screen navigation text } \\
\text { Comments provided after V\&V review: } \\
\text { Appendix F specifies selection from LLW } \\
\text { Process Menu - in Rev } 2 \text { of SDD, all sections } \\
\text { consistent } \\
\text { Action Completed and Discrepancy Item } \\
\text { Closed as of 5/17/96 }\end{array}$ \\
\hline $\begin{array}{l}\text { 0322: LLW RWM } \\
\text { Repackaging } \\
\text { 0326: LLW RWM Treatment }\end{array}$ & $\begin{array}{l}\text { screen print shows check box } \\
\text { for Compliant Waste- } \\
\text { Appendix } F \text { specifies } \\
\text { checkbox display }\end{array}$ & $\begin{array}{l}\text { no Appendix F mapping of } \\
\text { checkbox to a data element } \\
\text { - probably CONEXT } \\
\text { COMPLIANT_FLAG }\end{array}$ & $\begin{array}{l}\text { specifications } \\
\text { should be reviewed } \\
\text { against freld for } \\
\text { data storage }\end{array}$ & $\begin{array}{l}\text { Phase } 2 / 3 \text { SDD updates to be addressed as a } \\
\text { result of feature functional specification } \\
\text { reviews }\end{array}$ \\
\hline \multirow[t]{2}{*}{$\begin{array}{l}\text { 0323: LLW RWM Compliant } \\
\text { Waste Loadout }\end{array}$} & $\begin{array}{l}\text { specifies user entry for all } \\
\text { data except Waste Description }\end{array}$ & $\begin{array}{l}\text { since Waste Description is } \\
\text { for displayed drum PIN, } \\
\text { appears it should be edited } \\
\text { as drum contents are } \\
\text { changed }\end{array}$ & $\begin{array}{l}\text { should verify } \\
\text { editing rights for } \\
\text { this field }\end{array}$ & \multirow[t]{2}{*}{$\begin{array}{l}\text { Screen navigation specifications to be finalized } \\
\text { as a result of Phase } 2 / 3 \text { functional specification } \\
\text { reviews }\end{array}$} \\
\hline & $\begin{array}{l}\text { system navigation describes } \\
\text { entry of general waste drum } \\
\text { description via screen } 0322\end{array}$ & $\begin{array}{l}\text { requires user to return to } \\
\text { upper level screen for data } \\
\text { entry, while remainder of } \\
\text { update done at lower level } \\
\text { screen }\end{array}$ & $\begin{array}{l}\text { screen hierarchy } \\
\text { interaction should } \\
\text { be verified - may } \\
\text { not be best support } \\
\text { of user work flow }\end{array}$ & \\
\hline
\end{tabular}




\begin{tabular}{|c|c|c|c|c|}
\hline $\begin{array}{l}\text { SCREEN NAVIGATION } \\
\text { and APPENDIX A } \\
\text { SCREENS }\end{array}$ & $\begin{array}{l}\text { APPENDIX F, A, C } \\
\text { CONTENT }\end{array}$ & DISCREPANCY & $\begin{array}{l}\text { RATIONALE } \\
\text { FOR } \\
\text { CATEGORY }\end{array}$ & RESOLUTION \\
\hline $\begin{array}{l}\text { 0325: LLW RWM Processing } \\
\text { Instructions }\end{array}$ & $\begin{array}{l}\text { screen print appears to } \\
\text { provide for display of two } \\
\text { unnamed text fields }\end{array}$ & $\begin{array}{l}\text { Appendix F specifies } \\
\text { display of } \\
\text { TREAT_PROC_DESCR in } \\
\text { one of the fields - no } \\
\text { display specified for the } \\
\text { other field }\end{array}$ & $\begin{array}{l}\text { data presentation } \\
\text { may not be } \\
\text { complete }\end{array}$ & \multirow[t]{2}{*}{$\begin{array}{l}\text { Phase } 2 / 3 \text { SDD updates to be addressed as a } \\
\text { result of feature functional specification } \\
\text { reviews }\end{array}$} \\
\hline 0326: LLW RWM Treatment & $\begin{array}{l}\text { specifies Matl Group column } \\
\text { display of } \\
\text { CONEXT_USE_CD "if } \\
\text { column } 2= \\
\text { CONR_FROM_PKG_ID" }\end{array}$ & $\begin{array}{l}\text { no "else" statement: i.e., } \\
\text { no specification of what to } \\
\text { display if column } 2 \text { does } \\
\text { not }= \\
\text { CONR_FROM_PKG_ID }\end{array}$ & $\begin{array}{l}\text { logic may not } \\
\text { support all } \\
\text { instances of record } \\
\text { status or display }\end{array}$ & \\
\hline 0452: Location Table & $\begin{array}{l}\text { system administration of the } \\
\text { LOCN table }\end{array}$ & $\begin{array}{l}\text { no mention in latest SDD } \\
\text { version Screen Navigation } \\
\text { - however, screen print } \\
\text { still in Appendix A }\end{array}$ & $\begin{array}{l}\text { unclear if desired } \\
\text { for development - } \\
\text { table still needs } \\
\text { maintenance }\end{array}$ & $\begin{array}{l}\text { Screen navigation specifications to be finalized } \\
\text { as a result of Phase } 2 / 3 \text { functional specification } \\
\text { reviews }\end{array}$ \\
\hline
\end{tabular}




\begin{tabular}{|c|c|c|c|c|}
\hline $\begin{array}{l}\text { SCREEN NAVIGATION } \\
\text { and APPENDIX A } \\
\text { SCREENS }\end{array}$ & $\begin{array}{l}\text { APPENDIX F, A, C } \\
\text { CONTENT }\end{array}$ & DISCREPANCY & $\begin{array}{l}\text { RATIONALE } \\
\text { FOR } \\
\text { CATEGORY }\end{array}$ & RESOLUTION \\
\hline 0501: LLW Sample Data & $\begin{array}{l}\text { sample management screen } \\
\text { called }\end{array}$ & $\begin{array}{l}\text { no mention in Screen } \\
\text { Navigation or Appendix A } \\
\text { - not clear how signature } \\
\text { password will be requested } \\
\text { or entered - requirements } \\
\text { for signature password } \\
\text { discussed in V\&V } \\
\text { Appendix A, paragraph } \\
\text { 3.3.a Security }\end{array}$ & $\begin{array}{l}\text { signature password } \\
\text { necessity and use } \\
\text { needs to be } \\
\text { validated }\end{array}$ & $\begin{array}{l}\text { note signature password matrix following } \\
\text { process-- Data Dictionary matrix preceding }\end{array}$ \\
\hline $\begin{array}{l}\text { Pop-Up: LLW Physical } \\
\text { Composition }\end{array}$ & $\begin{array}{l}\text { display and allow user to } \\
\text { modify physical composition } \\
\text { for drum being sorted }\end{array}$ & $\begin{array}{l}\text { UP2: LLW Sorting Table } \\
\text { allows deletion of records } \\
\text { - unclear if Appendix F is } \\
\text { permitting delete/add of } \\
\text { entire records or discreet } \\
\text { data in records or both }\end{array}$ & $\begin{array}{l}\text { edit rights should } \\
\text { be clarified }\end{array}$ & $\begin{array}{l}\text { 1/30/96: Test Proc Review Meet: screen } \\
\text { navigation description should be updated } \\
\text { Comments provided after review of V\&V } \\
\text { discrepancies: ORACLE requires delete prior } \\
\text { to update of records - terminology includes } \\
\text { technical solution which fulfills screen } \\
\text { navigation as described } \\
\text { Discrepancy Item Closed }\end{array}$ \\
\hline 0315: LLW Exit Glovebox & $\begin{array}{l}\text { user allowed to modify the } \\
\text { outer drum waste description, } \\
\text { seal number and void code }\end{array}$ & $\begin{array}{l}\text { UP6: LLW Exit Glovebox } \\
\text { Product Drum Update } \\
\text { specifies display of } \\
\text { CONLOC_ID - uses a } \\
\text { location code - probably } \\
\text { intended to be LOCN_ID? }\end{array}$ & $\begin{array}{l}\text { should validate data } \\
\text { to be displayed on } \\
\text { screen }\end{array}$ & $\begin{array}{l}\text { 1/30/96: Test Proc Review Meet: Appendix F } \\
\text { should specify CONLOC_LOCN_ID } \\
\text { Action Completed in Rev } 2 \text { of SDD - } \\
\text { Discrepancy Item Closed }\end{array}$ \\
\hline
\end{tabular}




\begin{tabular}{|c|c|c|c|c|}
\hline $\begin{array}{c}\text { SCREEN NAVIGATION } \\
\text { and APPENDIX A } \\
\text { SCREENS }\end{array}$ & $\begin{array}{l}\text { APPENDIX F, A, C } \\
\text { CONTENT }\end{array}$ & DISCREPANCY & $\begin{array}{l}\text { RATIONALE } \\
\text { FOR } \\
\text { CATEGORY }\end{array}$ & RESOLUTION \\
\hline & $\begin{array}{l}\text { puck height displayed is a } \\
\text { default system setup } \\
\text { parameter }\end{array}$ & $\begin{array}{l}\text { UP6: LLW Exit Glovebox } \\
\text { Product Drum Update } \\
\text { source has no indication of } \\
\text { source for Puck Height } \\
\text { system default }\end{array}$ & $\begin{array}{l}\text { data may not be } \\
\text { available for } \\
\text { display }\end{array}$ & $\begin{array}{l}\text { 1/30/96: Test Proc Review Meet: data element } \\
\text { added to WRAPMISC table - need to update } \\
\text { lookup table values in Appendix G } \\
\text { Action Completed with table C-3 in Rev } 2 \text { of } \\
\text { SDD - Discrepancy Item Closed }\end{array}$ \\
\hline & \multirow[t]{2}{*}{ none } & $\begin{array}{l}\text { UP9: Create NDA record } \\
\text { for the product drum and } \\
\text { UP10: Create NDAISO } \\
\text { records for the product } \\
\text { drum, have no trigger } \\
\text { specified for NDA and } \\
\text { NDAISO records - implies } \\
\text { a part of } 0315 \text { intention - } \\
\text { System Navigation does } \\
\text { not mention processing - }\end{array}$ & $\begin{array}{l}\text { should verify that } \\
\text { screen navigation is } \\
\text { not fully descriptive }\end{array}$ & $\begin{array}{l}\text { 1/30/96: Test Proc Review Meet: should } \\
\text { update Screen Navigation text - need to revise } \\
\text { Para 5.2.4.10 }\end{array}$ \\
\hline & & $\begin{array}{l}\text { Appendix F description of } \\
\text { Commit button, but no } \\
\text { discussion of what happens } \\
\text { when used except to } \\
\text { request signature password } \\
\text { not clear how signature } \\
\text { password will be requested } \\
\text { or entered }\end{array}$ & $\begin{array}{l}\text { implies data base } \\
\text { update - signature } \\
\text { password checking } \\
\text { not clear }\end{array}$ & $\begin{array}{l}\text { 1/30/96: Test Proc Review Meet: SDD } \\
\text { paragraph } 5.1 \text { will be updated to require a } \\
\text { signature password for all data base commits - } \\
\text { the term "commit" is in reference to an } \\
\text { ORACLE commit }\end{array}$ \\
\hline
\end{tabular}




\begin{tabular}{|c|c|c|c|c|}
\hline $\begin{array}{l}\text { SCREEN NAVIGATION } \\
\text { and APPENDIX A } \\
\text { SCREENS }\end{array}$ & $\begin{array}{l}\text { APPENDIX F, A, C } \\
\text { CONTENT }\end{array}$ & DISCREPANCY & $\begin{array}{l}\text { RATIONALE } \\
\text { FOR } \\
\text { CATEGORY }\end{array}$ & RESOLUTION \\
\hline $\begin{array}{l}\text { Sample Management Menu: } \\
\text { allow user to select... (list of } \\
\text { screens) }\end{array}$ & $\begin{array}{l}\text { Appendix } F \text { also specifies an } \\
\text { additional screen called } \\
\text { "Returned Samples" }\end{array}$ & $\begin{array}{l}\text { no other indication of need } \\
\text { for this screen }\end{array}$ & $\begin{array}{l}\text { appears Appendix F } \\
\text { ahead of design in } \\
\text { other parts of SDD }\end{array}$ & \multirow[t]{4}{*}{$\begin{array}{l}\text { Screen navigation specifications to be finalized } \\
\text { as a result of Phase } 2 / 3 \text { functional specification } \\
\text { reviews }\end{array}$} \\
\hline \multirow{3}{*}{$\begin{array}{l}\text { 502: Electronic Chain of } \\
\text { Custody } \\
\text { allow user update of electronic } \\
\text { chain of custody } \\
\text { record retained for life of } \\
\text { sample } \\
\text { allow user to enter specific } \\
\text { data related to handling of } \\
\text { samples }\end{array}$} & specifies user entry & $\begin{array}{l}\text { no specification for data } \\
\text { element update/display - } \\
\text { unclear of relationship } \\
\text { between PKG_ID and } \\
\text { CONEXT_USE_CD='TP' }\end{array}$ & $\begin{array}{l}\text { need to specify } \\
\text { clearly the data } \\
\text { element to retrieve }\end{array}$ & \\
\hline & $\begin{array}{l}\text { no record retention } \\
\text { specifications }\end{array}$ & $\begin{array}{l}\text { process flows seem to } \\
\text { imply (or cause) record } \\
\text { stays active through the } \\
\text { duration for the UPs that } \\
\text { affect the data - happens } \\
\text { by "default" }\end{array}$ & $\begin{array}{l}\text { if more formal } \\
\text { approach needed to } \\
\text { safeguard data, it } \\
\text { should be specified }\end{array}$ & \\
\hline & $\begin{array}{l}\text { Appendix } F \text { has no such } \\
\text { specification for entering of } \\
\text { sample data }\end{array}$ & $\begin{array}{l}\text { screen specified only } \\
\text { permits review and } \\
\text { confirmation of chain of } \\
\text { custody }\end{array}$ & $\begin{array}{l}\text { data interaction by } \\
\text { user needs to be } \\
\text { confirmed }\end{array}$ & \\
\hline
\end{tabular}




\begin{tabular}{|c|c|c|c|c|}
\hline $\begin{array}{c}\text { SCREEN NAVIGATION } \\
\text { and APPENDIX A } \\
\text { SCREENS }\end{array}$ & $\begin{array}{l}\text { APPENDIX F, } A, C \\
\text { CONTENT }\end{array}$ & DISCREPANCY & $\begin{array}{l}\text { RATIONALE } \\
\text { FOR } \\
\text { CATEGORY }\end{array}$ & RESOLUTION \\
\hline $\begin{array}{l}\text { 0505: Waste Designation } \\
\text { allow user to update } \\
\text { descriptions and designation } \\
\text { codes }\end{array}$ & $\begin{array}{l}\text { no specification for edit of } \\
\text { description or comments }\end{array}$ & $\begin{array}{l}\text { all fields in HAZDETAIL, } \\
\text { CHEMCOMP, APPMSDS } \\
\text { are available for user } \\
\text { selection }\end{array}$ & $\begin{array}{l}\text { "edit" and "update" } \\
\text { terms may be } \\
\text { confused in } \\
\text { semantics }\end{array}$ & \\
\hline $\begin{array}{l}\text { 0506: Worksheet Data Entry } \\
\text { instructions displayed on back } \\
\text { of gloveboxes }\end{array}$ & none & $\begin{array}{l}\text { no mention in Appendix } F \\
\text { of display on a glovebox } \\
\text { monitor }\end{array}$ & $\begin{array}{l}\text { specified in RWM } \\
\text { specs - should be } \\
\text { included here }\end{array}$ & \\
\hline 0508: Sample Labels & List of Values Button & $\begin{array}{l}\text { no specification for use of } \\
\text { LOV button or display of } \\
\text { it }\end{array}$ & \multirow{2}{*}{$\begin{array}{l}\text { specifications need } \\
\text { to be validated } \\
\text { against screen } \\
\text { requirements }\end{array}$} & \\
\hline 0509: Sample/Bottle Tracking & $\begin{array}{l}\text { screen print shows List of } \\
\text { Values Button }\end{array}$ & $\begin{array}{l}\text { no Appendix F mapping to } \\
\text { LOV }\end{array}$ & & \\
\hline 0511: Returned Samples & $\begin{array}{l}\text { no system navigation } \\
\text { description - shown in } \\
\text { Appendix } A \text { and specified in } \\
\text { Appendix } C\end{array}$ & $\begin{array}{l}\text { seems identical to } 0510 \\
\text { expect for radio buttons - } \\
\text { perhaps could use same } \\
\text { screen and simple subdue } \\
\text { buttons based on a } \\
\text { determination of "new" or } \\
\text { "returned" }\end{array}$ & $\begin{array}{l}\text { specifications may } \\
\text { be ahead of other } \\
\text { parts of SDD } \\
\text { design - use of } \\
\text { previous screen } \\
\text { could simplify } \\
\text { design }\end{array}$ & \\
\hline
\end{tabular}




\begin{tabular}{|c|c|c|c|c|}
\hline $\begin{array}{c}\text { SCREEN NAVIGATION } \\
\text { and APPENDIX A } \\
\text { SCREENS } \\
\end{array}$ & $\begin{array}{l}\text { APPENDIX F, A, C } \\
\text { CONTENT }\end{array}$ & DISCREPANCY & $\begin{array}{l}\text { RATIONALE } \\
\text { FOR } \\
\text { CATEGORY }\end{array}$ & RESOLUTION \\
\hline $\begin{array}{l}\text { Shipping Menu: prompt user } \\
\text { for any additional data } \\
\text { required to complete } \\
\text { appropriate shipping forms }\end{array}$ & $\begin{array}{l}\text { UP1: Selection of WRAP } \\
\text { shipment to be completed - } \\
\text { no "prompt", but all data } \\
\text { displayed for user review and } \\
\text { edit, as appropriate to edit } \\
\text { rights }\end{array}$ & $\begin{array}{l}\text { no Appendix A } \\
\text { specifications for screen } \\
\text { displays described in } \\
\text { Appendix F for RSR Data } \\
\text { and UHWM Data }\end{array}$ & $\begin{array}{l}\text { cannot verify } \\
\text { content of } \\
\text { subscreens }\end{array}$ & $r$ \\
\hline $\begin{array}{l}\text { 601: Loading Dock Shipping } \\
\text { Data - forms to be completed: } \\
\text { Uniform Hazardous Waste } \\
\text { Manifest (UHWWM) } \\
\text { Radioactive Shipment } \\
\text { Record (RSR) } \\
\text { Solid Waste Storage! } \\
\text { Disposal Record (SWSDR) }\end{array}$ & $\begin{array}{l}\text { UP1: Selection of WRAP } \\
\text { shipment to be completed - } \\
\text { specifies RSR and UHWM } \\
\text { for selection - subscreens } \\
\text { then describe forms }\end{array}$ & $\begin{array}{l}\text { additional buttons listed } \\
\text { but never specified: } \\
\text { LLWSDR, RMWAS - }\end{array}$ & $\begin{array}{l}\text { may be missing } \\
\text { necessary support - } \\
\text { or additional } \\
\text { support is planned } \\
\text { and not } \\
\text { implemented }\end{array}$ & \\
\hline $\begin{array}{l}\text { 602: Loading Dock Container } \\
\text { Shipping }\end{array}$ & $\begin{array}{l}\text { UP9: Display of waste } \\
\text { containers for shipment - user } \\
\text { select buttons: SEND } \\
\text { SHIPMENT PICK LIST TO } \\
\text { PCS, IN TRANSIT }\end{array}$ & $\begin{array}{l}\text { no specification citing } \\
\text { shipment authorization, } \\
\text { however, these buttons } \\
\text { imply "de facto" } \\
\text { authorization and } \\
\text { signature/password } \\
\text { authority is required }\end{array}$ & $\begin{array}{l}\text { unclear if screen } \\
\text { design supports } \\
\text { needed processing }\end{array}$ & \\
\hline
\end{tabular}




\begin{tabular}{|c|c|c|c|c|}
\hline $\begin{array}{l}\text { SCREEN NAVIGATION } \\
\text { and APPENDIX A } \\
\text { SCREENS }\end{array}$ & $\begin{array}{l}\text { APPENDIX F, A, C } \\
\text { CONTENT }\end{array}$ & DISCREPANCY & $\begin{array}{l}\text { RATIONALE } \\
\text { FOR } \\
\text { CATEGORY }\end{array}$ & RESOLUTION \\
\hline \multirow[t]{2}{*}{$\begin{array}{l}\text { all administration and } \\
\text { maintenance screens }\end{array}$} & N/A & $\begin{array}{l}\text { no specifications exist for } \\
\text { any screens, validation } \\
\text { rules, table calls, edit } \\
\text { rights, etc. }\end{array}$ & $\begin{array}{l}\text { action of screen } \\
\text { dependent on } \\
\text { interpretation of } \\
\text { screen print }\end{array}$ & $\begin{array}{l}\text { Comments provided after review of V\&V } \\
\text { discrepancies: screens will be addressed in } \\
O \& M \text { and System Administration Manuals }\end{array}$ \\
\hline & none & $\begin{array}{l}\text { no system administration } \\
\text { or maintenance screens } \\
\text { specified for tables: } \\
\text { PKGSTAT } \\
\text { TRUSHIPCAT } \\
\text { USERSIGNPASS } \\
\text { WRAPROLE }\end{array}$ & $\begin{array}{l}\text { unclear how tables } \\
\text { to be maintained }\end{array}$ & $\begin{array}{l}\text { Screen navigation specifications to be finalized } \\
\text { as a result of Phase } 2 / 3 \text { functional specification } \\
\text { reviews }\end{array}$ \\
\hline 0702: User Table & USER table & $\begin{array}{l}\text { unclear how } \\
\text { USR_USERID, } \\
\text { USR_NAME, } \\
\text { USR_PERS_ID relate to } \\
\text { Person table - edited here } \\
\text { and loaded to PERSON? }\end{array}$ & $\begin{array}{l}\text { Appendix } \mathrm{H} \text { has } \\
\text { been updated, but } \\
\text { design issue of } \\
\text { interaction with } \\
\text { PERSON table still } \\
\text { unresolved as of } \\
\text { phase } 2 \mathrm{~V} \& \mathrm{~V}\end{array}$ & $\begin{array}{l}\text { 1/18/96: Test Proc Review Meet: no forced } \\
\text { relationship between USER and PERSON table } \\
\text { - can pull in data if available in PERSON, but } \\
\text { not updated back - future design item, not in } \\
\text { Phase } 1 \text { - remove PERSON table from } \\
\text { Appendix } \mathrm{H} \text { as a joint SWITS table } \\
\text { Appendix } \mathrm{H} \text { update Action Completed and } \\
\text { that portion of Discrepancy Item Closed as } \\
\text { of } 3 / 6 / 96\end{array}$ \\
\hline
\end{tabular}




\begin{tabular}{|c|c|c|c|c|}
\hline $\begin{array}{c}\text { SCREEN NAVIGATION } \\
\text { and APPENDIX A } \\
\text { SCREENS }\end{array}$ & $\begin{array}{l}\text { APPENDIX F, A, C } \\
\text { CONTENT }\end{array}$ & DISCREPANCY & $\begin{array}{l}\text { RATIONALE } \\
\text { FOR } \\
\text { CATEGORY } \\
\end{array}$ & RESOLUTION \\
\hline $\begin{array}{l}\text { 0710: Field Help Table } \\
\text { (Screen Navigation only) }\end{array}$ & DATADICT table & $\begin{array}{l}\text { not listed in Appendix A - } \\
\text { listed in Appendix H as a } \\
\text { shared table with SWITS }\end{array}$ & $\begin{array}{l}\text { should clarify data } \\
\text { edit rights for each } \\
\text { system }\end{array}$ & $\begin{array}{l}\text { 1/18/96: Test Proc Review Meet: need to } \\
\text { update Appendix H - not a shared table with } \\
\text { SWITS - update Appendix A to indicate a table } \\
\text { for future definition } \\
\text { Action Completed and Discrepancy Item } \\
\text { Closed as of } 3 / 6 / 96\end{array}$ \\
\hline \multirow[t]{2}{*}{ 0711: Form Help Table } & & $\begin{array}{l}\text { listed in Appendix A, but } \\
\text { no screen print available } \\
\text { for review }\end{array}$ & $\begin{array}{l}\text { may be an } \\
\text { unnecessary screen } \\
\text { as of Phase } 2 \\
V \& V \text {, still open }\end{array}$ & $\begin{array}{l}\text { 1/18/96: Test Proc Review Meet: update } \\
\text { Appendix A to indicate a table for future } \\
\text { definition. Screen navigation specifications to } \\
\text { be finalized as a result of Phase } 2 / 3 \text { functional } \\
\text { specification reviews }\end{array}$ \\
\hline & & $\begin{array}{l}\text { listed in Appendix } \mathrm{H} \text { as a } \\
\text { shared table with SWITS }\end{array}$ & $\begin{array}{l}\text { may have } \\
\text { superseded need for } \\
\text { screen }\end{array}$ & $\begin{array}{l}\text { 1/18/96: Test Proc Review Meet: need to } \\
\text { update Appendix H - not a shared table with } \\
\text { SWITS } \\
\text { Action Completed and Discrepancy Item } \\
\text { Closed as of } 3 / 6 / 96\end{array}$ \\
\hline $\begin{array}{l}\text { 0901: Download Processing } \\
\text { List }\end{array}$ & no match & $\begin{array}{l}\text { 3.1.6/UP1: Process List } \\
\text { Additions - allows user to } \\
\text { resequence numbers and to } \\
\text { Reorder and Commit - no } \\
\text { such discussion in Screen } \\
\text { Navigation }\end{array}$ & $\begin{array}{l}\text { should verify that } \\
\text { sequence numbers } \\
\text { are not system } \\
\text { generated }\end{array}$ & $\begin{array}{l}\text { 2/20/96: Test Proc. Review Meet: need to } \\
\text { update Screen Navigation discussion to include } \\
\text { need for resequencing } \\
\text { Action Completed and Discrepancy Item } \\
\text { Closed as of } 3 / 6 / 96\end{array}$ \\
\hline
\end{tabular}




\begin{tabular}{|c|c|c|c|c|}
\hline $\begin{array}{l}\text { SCREEN NAVIGATION } \\
\text { and APPENDIX A } \\
\text { SCREENS }\end{array}$ & $\begin{array}{l}\text { APPENDIX F, A, C } \\
\text { CONTENT }\end{array}$ & DISCREPANCY & $\begin{array}{l}\text { RATIONALE } \\
\text { FOR } \\
\text { CATEGORY }\end{array}$ & RESOLUTION \\
\hline \multirow[t]{2}{*}{. } & $\begin{array}{l}\text { PIN placed on AS/RS } \\
\text { retrieval via transfer car pick } \\
\text { list }\end{array}$ & $\begin{array}{l}\text { 3.1.6/UP5: AS/RS } \\
\text { Retrieval and Storage Via } \\
\text { Transfer Car - displays } \\
\text { pick list data for bins with } \\
\text { matching RDET_SWTYP } \\
\text { GROUP - no indication of } \\
\text { adding to list - } \\
\text { specifications seem to } \\
\text { display an existing pick list } \\
\text { rather than allowing user } \\
\text { to add to the pick list }\end{array}$ & $\begin{array}{l}\text { may not be } \\
\text { supporting desired } \\
\text { processing }\end{array}$ & $\begin{array}{l}\text { Comments provided after V\&V Review: } \\
\text { ability to pick an empty bin or bin storing } \\
\text { empty drums needs to be addressed during } \\
\text { Phase } 2 \text { specification reviews }\end{array}$ \\
\hline & $\begin{array}{l}\text { Screen Navigation states } \\
\text { system should store from } \\
\text { either transfer car or pallet } \\
\text { stand }\end{array}$ & $\begin{array}{l}\text { 3.1.6/UP5: AS/RS } \\
\text { Retrieval and Storage Via } \\
\text { Transfer Car does not } \\
\text { differentiate between } \\
\text { AS/RS pallet or transfer } \\
\text { car - UP implies that } \\
\text { entire process relates to } \\
\text { transfer car }\end{array}$ & $\begin{array}{l}\text { may not support } \\
\text { required } \\
\text { functionality }\end{array}$ & $\begin{array}{l}\text { Comments provided after review of V\&V } \\
\text { discrepancies: screen navigation should be } \\
\text { updated to clarify storage is only from transfer } \\
\text { car } \\
\text { Action Completed and Discrepancy Item } \\
\text { Closed as of } 3 / 6 / 96\end{array}$ \\
\hline
\end{tabular}




\begin{tabular}{|c|c|c|c|c|}
\hline $\begin{array}{c}\text { SCREEN NAVIGATION } \\
\text { and APPENDIX A } \\
\text { SCREENS }\end{array}$ & $\begin{array}{l}\text { APPENDIX F, A, C } \\
\text { CONTENT }\end{array}$ & DISCREPANCY & $\begin{array}{l}\text { RATIONALE } \\
\text { FOR } \\
\text { CATEGORY }\end{array}$ & RESOLUTION \\
\hline $\begin{array}{l}\text { 0904: AS/RS Shipping Pick } \\
\text { List }\end{array}$ & $\begin{array}{l}\text { allow user to group drums } \\
\text { into a shipment from loading } \\
\text { dock } \\
\text { assign a shipment ID to the } \\
\text { set }\end{array}$ & $\begin{array}{l}\text { UP7: AS/RS Shipping } \\
\text { Pick List - specifies } \\
\text { access to SHIPWRAP for } \\
\text { SHIPWRAP_NUM and to } \\
\text { SHIPPICK for SHIPPICK_ } \\
\text { WRAP_NUM and } \\
\text { SHIPPICK_PKG_ } \\
\text { ID, yet only uses } \\
\text { SHIPPICK_WRAP_ } \\
\text { NUM - }\end{array}$ & $\begin{array}{l}\text { unclear how the } \\
\text { other two data } \\
\text { elements apply }\end{array}$ & $\begin{array}{l}\text { Comments provided after review of V\&V } \\
\text { discrepancies: Appendix F } 3.1 .6 / \text { UP8 should } \\
\text { be updated } \\
\text { Action Completed and Discrepancy Item } \\
\text { Closed as of } 3 / 6 / 96\end{array}$ \\
\hline \multirow[t]{2}{*}{$\begin{array}{l}\text { 1101: Radiological Inventory } \\
\text { Summary }\end{array}$} & $\begin{array}{l}\text { Appendix F, UP1 says if } \\
\text { DMS role authorizes, allow } \\
\text { modification of Total, but } \\
\text { user cannot enter total equal } \\
\text { to or exceeding limit }\end{array}$ & \multirow[t]{2}{*}{$\begin{array}{l}\text { no mention of modification } \\
\text { in Screen Navigation } \\
\text { description }\end{array}$} & \multirow[t]{2}{*}{$\begin{array}{l}\text { need to verify that } \\
\text { modification is } \\
\text { desired function of } \\
\text { this screen }\end{array}$} & \multirow[t]{2}{*}{$\begin{array}{l}\text { 2/20/96: Test Proc. Review Meet: update } \\
\text { screen navigation description to indicate need } \\
\text { for data element modifications } \\
\text { Action Completed and Discrepancy Item } \\
\text { Closed as of } 3 / 6 / 96\end{array}$} \\
\hline & $\begin{array}{l}\text { Appendix } F, \text { UP1 has a } \\
\text { Commit button to update Rad } \\
\text { Alarm if Rad Total modified }\end{array}$ & & & \\
\hline
\end{tabular}




\begin{tabular}{|c|c|c|c|c|}
\hline $\begin{array}{l}\text { SCREEN NAVIGATION } \\
\text { and APPENDIX A } \\
\text { SCREENS }\end{array}$ & $\begin{array}{l}\text { APPENDIX F, A, C } \\
\text { CONTENT }\end{array}$ & DISCREPANCY & $\begin{array}{l}\text { RATIONALE } \\
\text { FOR } \\
\text { CATEGORY }\end{array}$ & RESOLUTION \\
\hline $\begin{array}{l}\text { 1201: Processed Waste NDA } \\
\text { Data Review and Modification }\end{array}$ & $\begin{array}{l}\text { user reviews NDA data } \\
\text { associated with waste drums } \\
\text { which are processed in } \\
\text { WRAP } 1 \text { - Appendix F UP1 } \\
\text { has several buttons used to } \\
\text { display specific data } \\
\text { categories }\end{array}$ & \multirow{3}{*}{$\begin{array}{l}\text { in general: screen design } \\
\text { specified in Appendix F } \\
\text { varies from screen print } \\
\text { layout in Appendix A - } \\
\text { besides inclusion of new } \\
\text { contents discussed in } \\
\text { Category } 1 \text { (see above), } \\
\text { Appendix F specifies } \\
\text { headers, user selection } \\
\text { activity, and data which } \\
\text { does not appear supported } \\
\text { by the screen print }\end{array}$} & \multirow[t]{3}{*}{$\begin{array}{l}\text { unclear if screen } \\
\text { print supports } \\
\text { required } \\
\text { functionality - if so, } \\
\text { Appendix } F \text { is out } \\
\text { of date }\end{array}$} & \multirow[t]{3}{*}{$\begin{array}{l}\text { Comments provided after V\&V review: } \\
\text { deviations pertain to pop-ups which are not } \\
\text { expected to be included in Appendix A - } \\
\text { Appendix F specifications will be followed } \\
\text { Discrepancy Item Closed as of } 5 / 17 / 96\end{array}$} \\
\hline $\begin{array}{l}\text { 1202: Compacted Drum NDA } \\
\text { Data Review }\end{array}$ & $\begin{array}{l}\text { user reviews NDA data } \\
\text { associated with individual } \\
\text { waste pucks which comprise } \\
\text { a product drum generated in } \\
\text { process area LLW Glovebox }\end{array}$ & & & \\
\hline $\begin{array}{l}\text { 1211: Verification NDA Data } \\
\text { Review }\end{array}$ & $\begin{array}{l}\text { user reviews NDA data } \\
\text { associated with waste drums } \\
\text { which are not processed in } \\
\text { WRAP facility }\end{array}$ & & & \\
\hline
\end{tabular}




\begin{tabular}{|c|c|c|c|c|}
\hline $\begin{array}{c}\text { SCREEN NAVIGATION } \\
\text { and APPENDIX A } \\
\text { SCREENS }\end{array}$ & $\begin{array}{l}\text { APPENDIX F, A, C } \\
\text { CONTENT }\end{array}$ & DISCREPANCY & $\begin{array}{l}\text { RATIONALE } \\
\text { FOR } \\
\text { CATEGORY }\end{array}$ & RESOLUTION \\
\hline \multirow[t]{2}{*}{$\begin{array}{l}\text { 1201: Processed Waste NDA } \\
\text { Data Review and Modification } \\
\text { 1202: Compacted Drum NDA } \\
\text { Data Review } \\
\text { 1211: Verification NDA Data } \\
\text { Review }\end{array}$} & $\begin{array}{l}\text { screens require display of } \\
\text { Total Isotopic Records }\end{array}$ & $\begin{array}{l}\text { no Appendix } F \\
\text { specification for data } \\
\text { element or computation } \\
\text { needed to display Total } \\
\text { Isotopic Records }\end{array}$ & $\begin{array}{l}\text { if specifications are } \\
\text { followed, screen } \\
\text { display may not be } \\
\text { generated }\end{array}$ & $\begin{array}{l}\text { Comments provided after V\&V Review: need } \\
\text { to revise Appendix } F \text { to require display - this } \\
\text { will be a local variable - count of query results } \\
\text { (number of corresponding NDAISO records). } \\
\text { Screen navigation specifications to be funalized } \\
\text { as a result of Phase } 2 / 3 \text { functional specification } \\
\text { reviews }\end{array}$ \\
\hline & $\begin{array}{l}\text { screens require display of } \\
\text { Revisit and Future Eval } \\
\text { Required }\end{array}$ & $\begin{array}{l}\text { Appendix F associated } \\
\text { Future Eval Required with } \\
\text { NDA_RVST_FLAG - no } \\
\text { indication of how this } \\
\text { relates or interacts with } \\
\text { Revisit display field }\end{array}$ & $\begin{array}{l}\text { unclear how these } \\
\text { displays relate to } \\
\text { each other - what } \\
\text { data element is } \\
\text { associated with } \\
\text { Revisit display and } \\
\text { how is field } \\
\text { used/loaded }\end{array}$ & $\begin{array}{l}\text { Comments provided after V\&V Review: } \\
\text { revisit = NDA_RVST_FLAG - future } \\
\text { evaluation = NDA_FUT_EVAL_REQD - } \\
\text { specifications are correct, no action needed } \\
\text { Discrepancy Item Closed as of } 5 / 17 / 96\end{array}$ \\
\hline $\begin{array}{l}\text { 1202: Compacted Drum NDA } \\
\text { Data Review }\end{array}$ & $\begin{array}{l}\text { screen is activated for } \\
\text { compacted drums only }\end{array}$ & $\begin{array}{l}\text { Appendix F refers to } \\
\text { screen } 1201 \text { retrieval for } \\
\text { CONR_FROM_PKG_ID } \\
\text { (LOV) } \text { CONR_TO_PKG_- }_{\text {CONOCON_PKG_ID } \cdot \text { no }} \\
\text { reference to } \\
\text { CONEXT_USE_CD }=\text { PU }\end{array}$ & $\begin{array}{l}\text { unclear how logic } \\
\text { will result in } \\
\text { retrieval of only } \\
\text { compacted drums }\end{array}$ & $\begin{array}{l}\text { Comments provided after V\&V Review: } \\
1202 \text { screen only available when "compacted" } \\
\text { selected on } 1201 \text { screen - see UP1 for logic } \\
\text { (CONR_FROM_PKG_ID can be either PU or } \\
\text { EC) - no action needed Discrepancy Item } \\
\text { Closed as of } 5 / 17 / 96\end{array}$ \\
\hline
\end{tabular}




\begin{tabular}{|c|c|c|c|c|}
\hline $\begin{array}{l}\text { SCREEN NAVIGATION } \\
\text { and APPENDIX A } \\
\text { SCREENS }\end{array}$ & $\begin{array}{l}\text { APPENDIX F, A, C } \\
\text { CONTENT }\end{array}$ & DISCREPANCY & $\begin{array}{l}\text { RATIONALE } \\
\text { FOR } \\
\text { CATEGORY }\end{array}$ & RESOLUTION \\
\hline \multirow[t]{2}{*}{$\begin{array}{l}\text { 1231: Verification Data } \\
\text { Review Waste Compliant }\end{array}$} & $\begin{array}{l}\text { allow the user to review and } \\
\text { modify data for a specific } \\
\text { drum that has only undergone } \\
\text { NDE and NDA exams in } \\
\text { WRAP }\end{array}$ & \multirow[t]{2}{*}{$\begin{array}{l}\text { Appendix F specifies } \\
\text { display of containers } \\
\text { indicating NDE Verified, } \\
\text { Assay Verified, Gross } \\
\text { Weight Verified flags set }\end{array}$} & $\begin{array}{l}\text { unclear how PINs } \\
\text { displayed are } \\
\text { identified as not } \\
\text { otherwise processed } \\
\text { in WRAP }\end{array}$ & $\begin{array}{l}\text { Comments provided after V\&V Review: } \\
\text { drums are designated as verification only by } \\
\text { route code which sets use code ( } 3.1 .6 / \text { UP } 4) \text { - } \\
\text { boxes, by definition, are verification only - no } \\
\text { action needed Discrepancy Item Closed as of } \\
5 / 17 / 96\end{array}$ \\
\hline & $\begin{array}{l}\text { only allow modification of } \\
\text { WRAP generated data }\end{array}$ & & $\begin{array}{l}\text { unclear how system } \\
\text { will identify and } \\
\text { restrict modification } \\
\text { to WRAP generated } \\
\text { data }\end{array}$ & $\begin{array}{l}\text { Comments provided after V\&V Review: } \\
\text { Appendix F CONEXT_data elements are } \\
\text { WRAP only data - screen only displays WRAP } \\
\text { data - no action needed Discrepancy Item } \\
\text { Closed }\end{array}$ \\
\hline 1301: Activity Comments & $\begin{array}{l}\text { use LOV to look up } \\
\text { CODECHECK for ACT_CD }\end{array}$ & $\begin{array}{l}\text { no reference to } \\
\text { CODECHECK table in } \\
\text { Appendix C data definition } \\
- \text { Appendix C lists all } \\
\text { ACT_CD values as } \\
\text { domain of ACT_CD }\end{array}$ & $\begin{array}{l}\text { appears that } \\
A C T C D \text { is } \\
\text { intended for lookup } \\
\text { - not clear if } \\
\text { reference to } \\
\text { CODECHECK is } \\
\text { required }\end{array}$ & $\begin{array}{l}\text { Phase } 2 / 3 \text { SDD updates to be addressed as a } \\
\text { result of feature functional specification } \\
\text { reviews }\end{array}$ \\
\hline
\end{tabular}




\begin{tabular}{|c|c|c|c|c|}
\hline $\begin{array}{c}\text { SCREEN NAVIGATION } \\
\text { and APPENDIX A } \\
\text { SCREENS }\end{array}$ & $\begin{array}{c}\text { APPENDIX F, A, C } \\
\text { CONTENT }\end{array}$ & DISCREPANCY & $\begin{array}{c}\text { RATIONALE } \\
\text { FOR } \\
\text { CATEGORY }\end{array}$ & RESOLUTION \\
\hline & $\begin{array}{l}\text { system navigation discusses } \\
\text { access to 1301 from any } \\
\text { screen via "fast access" } \\
\text { function - not specified } \\
\text { anywhere in SDD }\end{array}$ & $\begin{array}{l}\text { no reference to "fast } \\
\text { access" in any SDD } \\
\text { section or specification }\end{array}$ & $\begin{array}{l}\text { should probably } \\
\text { include at least in } \\
\text { general design } \\
\text { standards as a } \\
\text { generic feature of } \\
\text { DMS }\end{array}$ & $\begin{array}{l}\text { Screen navigation specifications to be finalized } \\
\text { as a result of Phase } 2 / 3 \text { functional specification }\end{array}$ \\
\hline
\end{tabular}




\begin{tabular}{|l|l|l|l|}
\hline \multicolumn{1}{|c|}{ TABLE } & \multicolumn{1}{|c|}{ NAME LISTING } & \multicolumn{1}{|c|}{$\begin{array}{c}\text { DATA DEFINIION } \\
\text { LISTING }\end{array}$} & \multicolumn{1}{|c|}{$\begin{array}{l}\text { RATIONALE FOR } \\
\text { CATEGORY }\end{array}$} \\
\hline DATA DICTIONARY TABLE/DATA ELEMENT NAME LISTING COMPARED TO DATA DICTIONARY TABLE/DATA DEFINITION LISTING \\
\hline
\end{tabular}




\begin{tabular}{|c|c|c|c|c|}
\hline TABLE & NAME LISTING & $\begin{array}{l}\text { DATA DEFINITION } \\
\text { LISTING }\end{array}$ & $\begin{array}{l}\text { RATIONALE FOR } \\
\text { CATEGORY }\end{array}$ & RESOLUTION \\
\hline PROCADD & $\begin{array}{l}\text { PROCADD_PKG_ID marked } \\
\text { as a primary key }\end{array}$ & $\begin{array}{l}\text { PROCADD_PKG_ID marked } \\
\text { as a primary and a foreign key }\end{array}$ & & \multirow{3}{*}{$\begin{array}{l}\text { Comments provided after review } \\
\text { of V\&V discrepancies: Appendix } \\
\text { C should be updated. Action } \\
\text { Completed and Discrepancy } \\
\text { Item Closed as of } 5 / 17 / 96\end{array}$} \\
\hline PROFILEISOO & $\begin{array}{l}\text { PISO_ISO_NAME marked as a } \\
\text { primary key }\end{array}$ & $\begin{array}{l}\text { PISO_ISO_NAME marked as a } \\
\text { primary and a foreign key }\end{array}$ & & \\
\hline RADDETAIL & $\begin{array}{l}\text { RDET_WRAP_CAT marked } \\
\text { as a foreign key }\end{array}$ & $\begin{array}{l}\text { RDET_WRAP_CAT not } \\
\text { marked as a key }\end{array}$ & & \\
\hline SECLOG & $\begin{array}{l}\text { SLOG_USER_ID marked as a } \\
\text { foreign key }\end{array}$ & $\begin{array}{l}\text { SLOG_USER marked as a } \\
\text { foreign key }\end{array}$ & $\begin{array}{l}\text { mismatch in data element name } \\
\text { for foreign keys - may affect } \\
\text { table access for correct record }\end{array}$ & $\begin{array}{l}\text { Comments provided after review } \\
\text { of V\&V discrepancies: Appendix } \\
\mathrm{C} \text { should be updated. Action } \\
\text { Completed and Discrepancy } \\
\text { Item Closed as of 5/17/96: table } \\
\text { deleted }\end{array}$ \\
\hline SHIPPICK & $\begin{array}{l}\text { SHIPPICK_WRAP_NUM } \\
\text { marked as a foreign and } \\
\text { primary key }\end{array}$ & $\begin{array}{l}\text { SHIPPICK_WRAP_NUM } \\
\text { marked only as a primary key }\end{array}$ & \multirow[t]{3}{*}{$\begin{array}{l}\text { may affect table access for } \\
\text { correct record }\end{array}$} & \multirow{3}{*}{$\begin{array}{l}\text { Comments provided after review } \\
\text { of V\&V discrepancies: Appendix } \\
C \text { should be updated. Action } \\
\text { Completed and Discrepancy } \\
\text { Item Closed as of } 5 / 17 / 96\end{array}$} \\
\hline SHIPWRAP & $\begin{array}{l}\text { SHIPWRAP_NUM marked as } \\
\text { a primary key }\end{array}$ & $\begin{array}{l}\text { SHIPWRAP_NUM marked as } \\
\text { both a primary and a foreign } \\
\text { key }\end{array}$ & & \\
\hline SIEISO & $\begin{array}{l}\text { SIE_ISO_NUM marked as a } \\
\text { secondary key }\end{array}$ & $\begin{array}{l}\text { SIE_ISO_NUM not marked as } \\
\text { a key }\end{array}$ & & \\
\hline
\end{tabular}




\begin{tabular}{|c|c|c|c|c|}
\hline TABLE & NAME LISTING & $\begin{array}{l}\text { DATA DEFINITION } \\
\text { LISTING }\end{array}$ & $\begin{array}{l}\text { RATIONALE FOR } \\
\text { CATEGORY }\end{array}$ & RESOLUTION \\
\hline \multirow[t]{2}{*}{ WASTE } & $\begin{array}{l}\text { CON_LOCN_FACIL_AREA } \\
\text { marked as a foreign key }\end{array}$ & $\begin{array}{l}\text { CON_LOCN_FACIL_AREA } \\
\text { not marked as a key }\end{array}$ & & \\
\hline & $\begin{array}{l}\text { CON_SEC_PKG_ID not } \\
\text { marked as a key }\end{array}$ & $\begin{array}{l}\text { CON_SEC_PKG_ID specified } \\
\text { as a foreign key }\end{array}$ & & $\begin{array}{l}\text { Comments provided after review } \\
\text { of V\&V discrepancies: Appendix } \\
C \text { should be updated. Action } \\
\text { Completed and Discrepancy } \\
\text { Item Closed as of } 5 / 17 / 96 \text { - } \\
\text { marked on both listings as a } \\
\text { unique index (U) }\end{array}$ \\
\hline
\end{tabular}




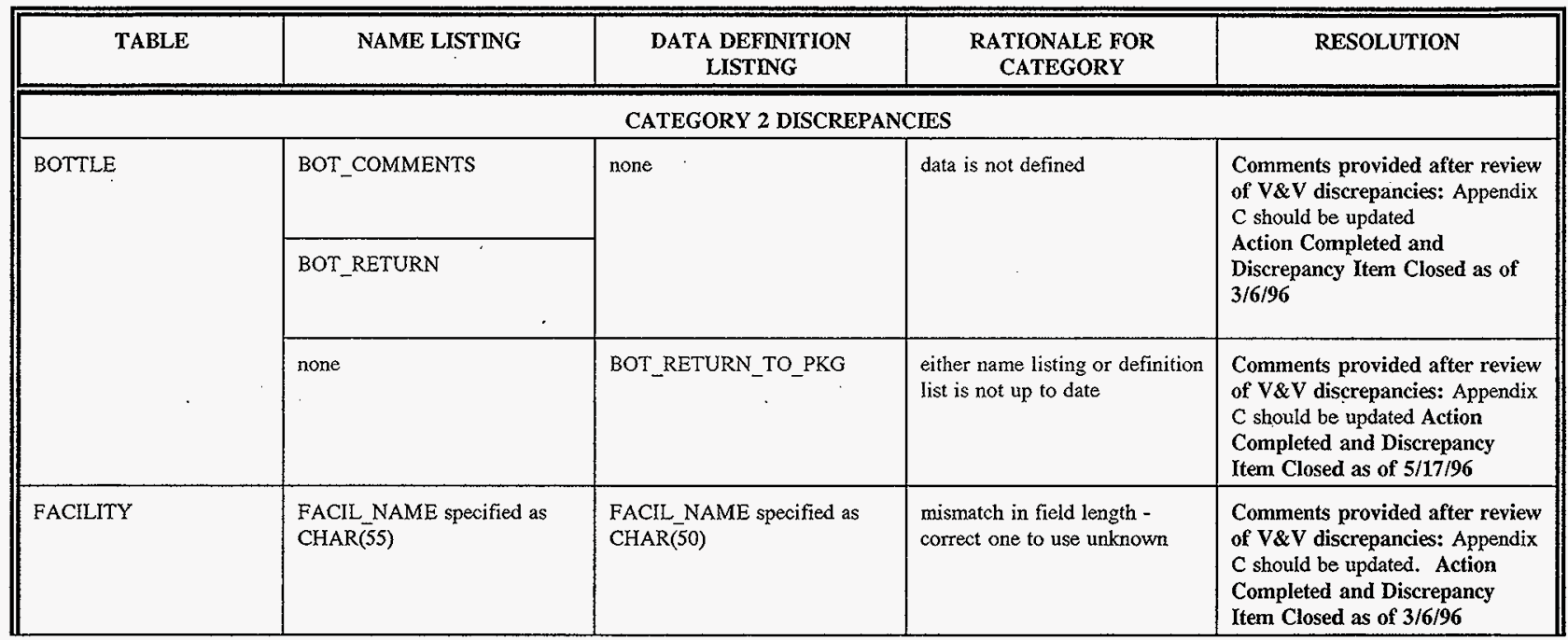




\begin{tabular}{|l|l|l|l|}
\hline \multicolumn{1}{|c|}{ TABLE } & \multicolumn{1}{|c|}{ NAME LISTNG } & \multicolumn{1}{|c|}{$\begin{array}{c}\text { DATA DEFINITION } \\
\text { LISTING }\end{array}$} & \multicolumn{1}{|c|}{$\begin{array}{c}\text { RATIONALE FOR } \\
\text { CATEGORY }\end{array}$} \\
\hline MATL & MATL_GRP_CD & MAT_GRP_CD & $\begin{array}{l}\text { mismatch in data element name } \\
\text { - correct one to use unknown }\end{array}$ \\
\hline SAMPLE & $\begin{array}{l}\text { Comments provided after review } \\
\text { of V\& discrepancies: Appendix } \\
\text { SAM_RETURN "redlined" out } \\
\text { of data element name listing }\end{array}$ & $\begin{array}{l}\text { SAM_RETURN shown with a } \\
\text { definition as a data element } \\
\text { still be used }\end{array}$ & $\begin{array}{l}\text { either name listing or definition } \\
\text { list is not up to date }\end{array}$ \\
$\begin{array}{l}\text { Completed and Discrepancy } \\
\text { Item Closed as of 5/17/96 }\end{array}$ \\
\hline SECWASTYPE & none & $\begin{array}{l}\text { SWTYP_DESCR shown with a } \\
\text { definition }\end{array}$ & $\begin{array}{l}\text { no listing for this data element } \\
\text { in the name listing - with name } \\
\text { listing or definition list is not } \\
\text { up to date }\end{array}$ \\
\hline
\end{tabular}




\section{DATA DICTIONARY CONTENT COMPARED TO DATA USAGE BY APPENDIX F SPECIFICATIONS}

The data dictionary appears to contain data elements that are:

- never loaded or used by any Appendix F process;

- loaded by some process, but not used;

- used by some process, but never loaded.

The following list of data elements should be reviewed to determine:

- if data is needed and missing from specifications;

- if data is not needed and should be deleted from data base. 
This review process should be considered a Category 1 discrepancy resolution. If any needed data are missing, the DMS system will not fulfill all of its purpose.

\begin{tabular}{|c|c|c|}
\hline DATA ELEMENT & COMMENTS & RESOLUTION \\
\hline \multicolumn{3}{|c|}{ Data Never Loaded or Used in the Specifications } \\
\hline BOT_RETURN_TO_PKG & Module 3.1.4/UP24 does use a BOT_RETURN_DT & \multirow{11}{*}{$\begin{array}{l}\text { Data contents validated during testing. Revised data } \\
\text { dictionary to be published as new baseline with "as- } \\
\text { built" SDD revision. Discrepancy Item Closed }\end{array}$} \\
\hline all of BOTANAL table & & \\
\hline COC_BILI_OF_LADING & & \\
\hline COC_PROPERTY_NUM & & \\
\hline COC_SAF_NUM & & \\
\hline COC_SPEC_HANDLING & redundant with COC_SPEC_INSTRUCTIONS? & \\
\hline CONTREAT_PKG_ID & $\begin{array}{l}\text { may be simply a foreign key passed from WASTE - } \\
\text { CON_PKG ID - and used by system to access table, } \\
\text { while not being used for any especial report or process }\end{array}$ & \\
\hline FIELD_SCRN_ID & a foreign key from some table? & \\
\hline HDET_CNTR_STATUS & \multirow{3}{*}{$\begin{array}{l}\text { these HAZDETAIL data elements are reviewed during } \\
\text { Data Review, but never seem to initialized - they may } \\
\text { be loaded from SWITS at some point, although they } \\
\text { are not named - they do not seem to have any use } \\
\text { during DMS processing }\end{array}$} & \\
\hline HDET_IND_DOT_ID_NUM & & \\
\hline HDET_IND_NOS_DESCR & & \\
\hline
\end{tabular}




\begin{tabular}{|c|c|c|}
\hline DATA ELEMENT & COMMENTS & RESOLUTION \\
\hline \multicolumn{3}{|l|}{ HDET_IND_SHIP_NAME } \\
\hline \multicolumn{3}{|l|}{ HDET_WASTE_STATUS } \\
\hline \multicolumn{3}{|l|}{ ASBLY_CONFIGURATION } \\
\hline \multicolumn{3}{|l|}{ ASBLY_SHIP_CAT } \\
\hline \multicolumn{3}{|l|}{ ASBLY_SHIP_CAT_HEAT_LTFLOAT } \\
\hline \multicolumn{3}{|l|}{ entire PKGDW table } \\
\hline \multicolumn{3}{|l|}{ RADMAT_DT } \\
\hline \multicolumn{3}{|l|}{ SAM_RETURN } \\
\hline \multicolumn{3}{|l|}{ SHPHST_NMIT_NUM } \\
\hline \multicolumn{3}{|l|}{ SHPHST_RETURN } \\
\hline \multicolumn{3}{|l|}{ SHPHST_741_NUM } \\
\hline \multicolumn{3}{|l|}{ SHPITM_PROFILE_NUM } \\
\hline \multicolumn{3}{|l|}{ SHPMNT_TSD_ACCEPT_DT } \\
\hline \multicolumn{3}{|l|}{ SHIPWRAP_CARRIER_PERS_ID } \\
\hline \multicolumn{2}{|l|}{ SHIPWRAP_MFST_COMP_FLAG } & \\
\hline TRUSHIP_DT & & \\
\hline
\end{tabular}




\begin{tabular}{|c|c|c|}
\hline DATA ELEMENT & COMMENTS & RESOLUTION \\
\hline \multicolumn{2}{|l|}{ CONEXT_HAZ_VER_FLAG } & \\
\hline \multicolumn{2}{|l|}{ CONEXT_RVST_FLAG } & \\
\hline CONEXT_SCRN_VER_FLAG & redundant with CONEXT_VER_NDE_FLAG? & \\
\hline \multicolumn{2}{|l|}{ CONEXT_WRAP_SAM_FLAG } & \\
\hline \multicolumn{2}{|c|}{ Data Elements that are Loaded, but Never Seem to be Used During Processing } & \\
\hline \multicolumn{2}{|l|}{ HDET_PCB_REMOVED_DT } & \\
\hline \multicolumn{2}{|l|}{ RDET_ASSAY_NUM } & \\
\hline \multicolumn{2}{|l|}{ RDET_CERT_DT } & \\
\hline \multicolumn{2}{|l|}{ RDET_DE_CL_FLAG } & \\
\hline \multicolumn{2}{|l|}{ RDET_HANDLING } & \\
\hline \multicolumn{2}{|l|}{ RDET_ORGANIC_WGT } & \\
\hline \multicolumn{2}{|l|}{ RDET_PDR_NUM } & \\
\hline \multicolumn{2}{|l|}{ RDET_RSWIMS_COUNT } & \\
\hline \multicolumn{2}{|l|}{ RDET_THERMAL_POWER_TMU } & \\
\hline \multicolumn{2}{|l|}{ RDET_TOT_ALPHA_CI_TMU } & \\
\hline RDET_TOT_PE_CI_TMU & & \\
\hline
\end{tabular}




\begin{tabular}{|c|c|c|}
\hline DATA ELEMENT & COMMENTS & RESOLUTION \\
\hline \multicolumn{2}{|l|}{ RDET_TOT_PU_FGE_TMU } & \\
\hline \multicolumn{2}{|l|}{ CON_CHEM_NATURE_CD } & \\
\hline CON_MFST_NUM & may be a foreign key used only for table access & \\
\hline \multicolumn{2}{|l|}{ CON_ROUTINE } & \\
\hline \multicolumn{2}{|l|}{ CON_SRCE_CHRG_CD } & \\
\hline \multicolumn{2}{|l|}{ CON_SRCE_CMPNY_TYPE } & \\
\hline \multicolumn{2}{|l|}{ CON_SRCE_ORG } & \\
\hline \multicolumn{2}{|l|}{ CON_TREATMENT_DT } & \\
\hline $\begin{array}{l}\text { METRIC table does not seem to get } \\
\text { created }\end{array}$ & & \\
\hline
\end{tabular}




\section{PHYSICAL (AS-BUILT ON MAY 1, 1996) DATABASE COMPARED TO DATA DICTIONARY}

This analysis compares all Phase 1 processing data elements and data elements having tables defined in Oracle in the SDD, against all data elements in the physical Oracle Database ("as built" as of May 1, 1996). Due to the difficulty in determining the proper phase for each data element, some phase 2 and phase 3 data elements were included for this V\&V analysis. If, in the summary section of the SDD, a table was defined as phase 2 or phase 3 , and it is not present in Oracle, then it was excluded from the analysis.

\section{General Category 2 Discrepancy:}

- Appendix C of the SDD has a summary table noting the phase tables and data elements belong to. It also notes the phase a data element belongs to in the detailed section of data definitions. These two sections are not consistent: The detail section lists three tables having phase 2 or phase 3 data elements-- NDA, NDAISO and ISOTOPE. The summary section list 29 tables as phase 2 or phase 3 as follows:

$\begin{array}{lrl}\text { Table Name } & \text { Phase } & \text { Comment } \\ \text { ACTCOM } & 2 & \text { Phase } 2 / 3 \text { sDD updates } \\ \text { BOTANAL } & 2 & \text { to be addressed as a } \\ \text { BOTTLE } & 2 & \text { result of feature } \\ \text { COC } & 2 & \text { functional specification } \\ \text { COCXFR } & 2 & \\ \text { CONTREAT } & 2 & \\ \text { FIELDANAI } & 2 & \\ \text { FIELDSCRN } & 2 & \\ \text { FLDANALTYP } & 2 & \\ \text { LAB } & 2 & \\ \text { Table Name } & \text { Phase } \text { Comment }\end{array}$


IABANAL

METRICS

PAM

PAYLOAD

PAYLOADASBLY

SAMLOC

SAMPCONTYP

SAMPLE

SAMPMATX

SAMPMETH

SAMREL

SAR

TREATPROC

TRUCON

TRUSHIP

TRUSHIPCAT

VERIFICATION

WORKITEM

WORKSHEET 


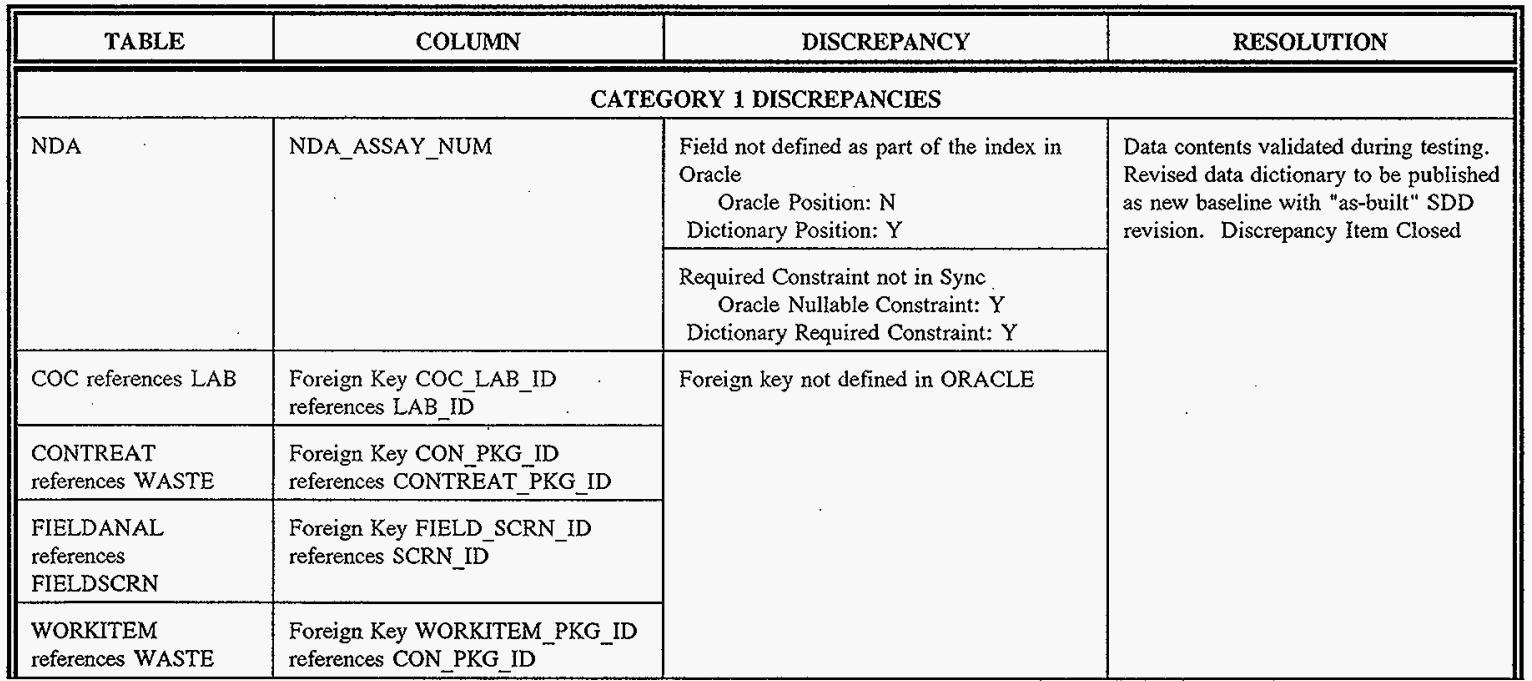




\begin{tabular}{|c|c|c|c|}
\hline TABLE & COLUMN & DISCREPANCY & RESOLUTION \\
\hline \multicolumn{4}{|c|}{ CATEGORY 2 DISCREPANCIES } \\
\hline $\mathrm{COC}$ & COC_LAB_ID & \multirow{10}{*}{$\begin{array}{l}\text { Dictionary Data Element does not exist in } \\
\text { Oracle }\end{array}$} & \multirow{10}{*}{$\begin{array}{l}\text { Data contents validated during testing. } \\
\text { Revised data dictionary to be published } \\
\text { as new baseline with "as-built" SDD } \\
\text { revision. Discrepancy Item Closed }\end{array}$} \\
\hline & COC_SHIP_DT & & \\
\hline \multirow[t]{2}{*}{ FIELDSCRN } & SCRN_COMMENTS & & \\
\hline & SCRN_ID & & \\
\hline \multirow[t]{2}{*}{ ISOTOPE } & ISO_ALPHA_CI_FACTR & & \\
\hline & ISO_PE_CI_FACTR & & \\
\hline \multirow{2}{*}{$\mathrm{NDA}$} & NDA_TOT_PE_CI_TMU & & \\
\hline & NDA_TOT_PU_FGE_TMU & & \\
\hline NDAISO & NDAISO_ASSAY_NUM & & \\
\hline SAMPLE & SAM_COC_FORM_ID & & \\
\hline
\end{tabular}




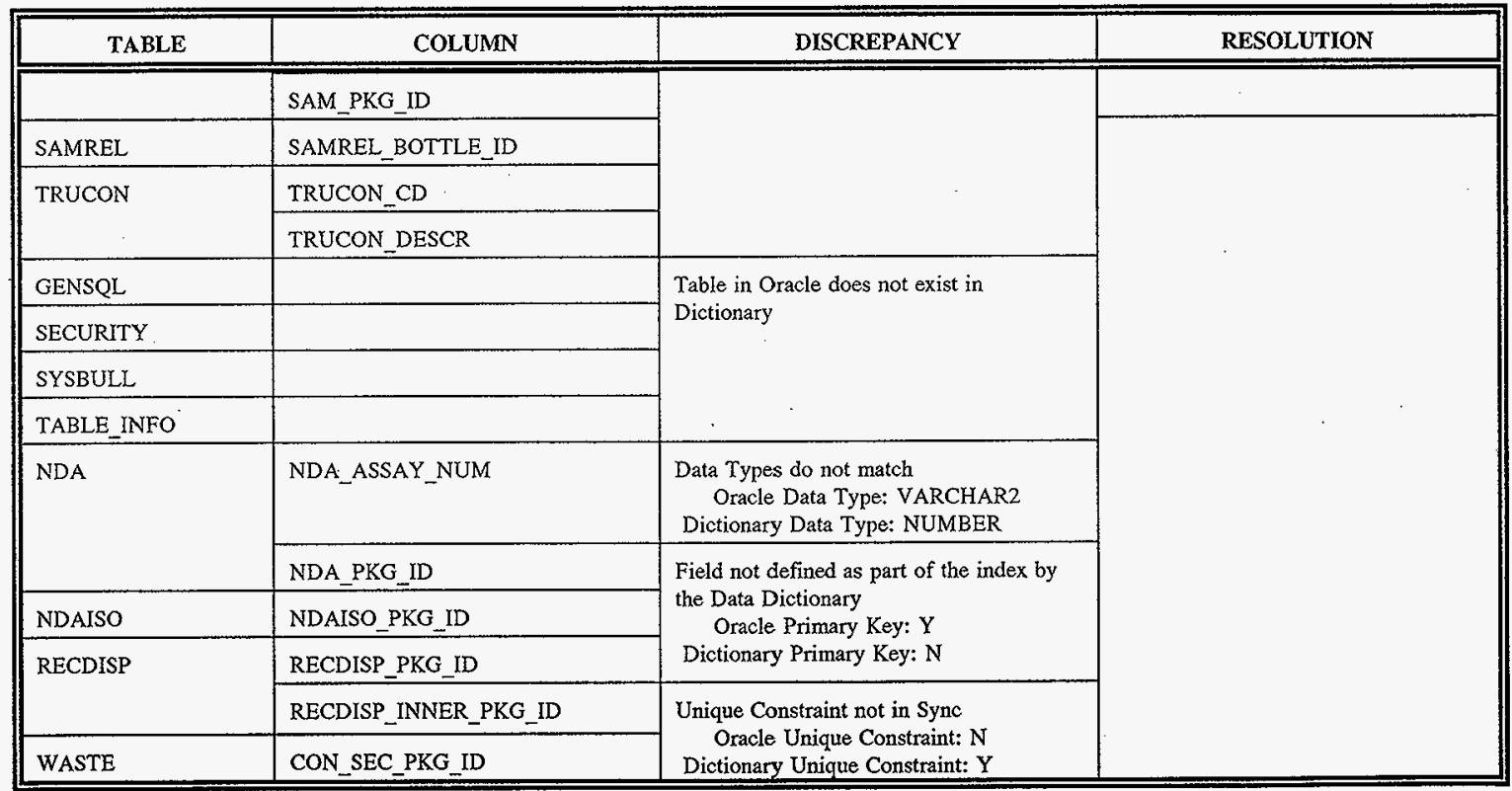


Oracle PL/SQL Stored Procedures

\begin{tabular}{|c|c|c|c|}
\hline PROCEDURE NAME & DISCREPANCY & $\begin{array}{l}\text { RATIONALE FOR } \\
\text { CATEGORY }\end{array}$ & RESOLUTION \\
\hline \multicolumn{4}{|c|}{ CATEGORY 1 DISCREPANCIES } \\
\hline \multirow[t]{4}{*}{ I_602_SWITS_RADDETAIL } & $\begin{array}{l}\text { The Oracle database has the field } \\
\text { RDET_THERMAL_POWER_TMU implemented in } \\
\text { DMS. The PL/SQL does not update this data element } \\
\text { in SWITS from DMS. }\end{array}$ & \multirow[t]{4}{*}{ SWITS is not being updated. } & \multirow[t]{4}{*}{$\begin{array}{l}\text { Data contents validated during } \\
\text { testing. Revised data dictionary to } \\
\text { be published as new baseline with } \\
\text { "as-built" SDD revision. } \\
\text { Discrepancy Item Closed }\end{array}$} \\
\hline & $\begin{array}{l}\text { The Oracle database has the field } \\
\text { RDET_TOT_ALPHA_CI_TMU implemented in DMS. } \\
\text { The PL/SQL does not update this data element in } \\
\text { SWITS from DMS. }\end{array}$ & & \\
\hline & $\begin{array}{l}\text { The Oracle database has the field } \\
\text { RDET_TOT_PE_CI_TMU implemented in DMS. The } \\
\text { PL/SQL_ does not update this data element in SWITS }\end{array}$ & & \\
\hline & $\begin{array}{l}\text { The Oracle database has the field } \\
\text { RDET_TOT_PU_FGE_TMU implemented in DMS. } \\
\text { The PL/SQL does not update this data element in } \\
\text { sWITS from DMS. }\end{array}$ & & \\
\hline
\end{tabular}




\begin{tabular}{|c|c|c|c|}
\hline PROCEDURE NAME & DISCREPANCY & $\begin{array}{l}\text { RATTONALE FOR } \\
\text { CATEGORY }\end{array}$ & RESOLUTION \\
\hline \multirow[t]{4}{*}{ I_RADDET_SWITS } & $\begin{array}{l}\text { The Oracle database has the field } \\
\text { RDET_THERMAL_POWER_TMU implemented in } \\
\text { DMS. The PL/SQL does not update this data element. } \\
\text { in DMS from SWITS. }\end{array}$ & \multirow[t]{4}{*}{ DMS is not being updated. } & \multirow[t]{6}{*}{. } \\
\hline & $\begin{array}{l}\text { The Oracle database has the field } \\
\text { RDET_TOT_ALPHA_CI_TMU implemented in DMS. } \\
\text { The PL/SQL does not update this data element in DMS } \\
\text { from SWITS. }\end{array}$ & & \\
\hline & $\begin{array}{l}\text { The Oracle database has the field } \\
\text { RDET TOT_PE_CI_TMU implemented in DMS. The } \\
\text { PL/SQL does not update this data element in this data } \\
\text { element in DMS from SWISS. }\end{array}$ & & \\
\hline & $\begin{array}{l}\text { The Oracle database has the field } \\
\text { RDET_TOT_PU_FGE_TMU implemented in DMS. } \\
\text { The PL/SQL does not update this data element in this } \\
\text { data element in DMS from sWITS. }\end{array}$ & & \\
\hline i_602_swits_isoqty & $\begin{array}{l}\text { The Oracle database has the field RAD_QTY TMU } \\
\text { implemented in DMS. The PL/SQL does not update } \\
\text { this data element in SWITS from DMS. }\end{array}$ & SWITS is not being updated. & \\
\hline I_ISOQTY_SWITS & $\begin{array}{l}\text { The Oracle database has the field RAD_QTY_TMU } \\
\text { implemented in DMS. The PL/SQL does not update } \\
\text { this data element in DMS from SWTS. }\end{array}$ & DMS is not being updated. & \\
\hline
\end{tabular}




\begin{tabular}{|c|c|c|c|}
\hline PROCEDURE NAME & DISCREPANCY & $\begin{array}{l}\text { RATIONALE FOR } \\
\text { CATEGORY }\end{array}$ & RESOLUTION \\
\hline REN_WASTE_PRIMKEY & $\begin{array}{l}\text { PROCADD table not being updated due to table lock. } \\
\text { Code is comented out. } \\
\text { /* } \\
\text { * THE FOLLOWING HAS BEEN COMMENTED } \\
\text { OUT BECAUSE } \\
\text { * THERE EXISTS A FULL TABLE LOCK ON } \\
\text { THESE TWO } \\
\text { * TABLES. IF THIS IS A PROBLEM FOR THHS } \\
\text { KIND OF } \\
\text { * UPDATING OF A PKG ID IN THE FUTURE, } \\
\text { THIS WILL } \\
\text { * NEED TO BE RE-THOUGHT OUT. } \\
\text { UPDATE PROCADD } \\
\text { SET PROCADD_PKGID = NEW_PKG_ID } \\
\text { WHERE PROCADD_PKG_ID = OLD_PKG_ID; } \\
\text { UPDATE PROCLIST } \\
\text { SET PROC_PKG_ID = NEW_PKG_ID } \\
\text { WHERE PROC_PKG_ID = OLD_PKG_ID; } \\
\text { *I }\end{array}$ & & \\
\hline
\end{tabular}




\begin{tabular}{|c|c|c|c|}
\hline PROCEDURE NAME & DISCREPANCY & $\begin{array}{l}\text { RATIONALE FOR } \\
\text { CATEGORY }\end{array}$ & RESOLUTION \\
\hline REN_WASTE_PRIMKEY & $\begin{array}{l}\text { PROCLIST table not being updated due to table lock. } \\
\text { Code is comented out. } \\
\text { * } \\
\text { * THE FOLLOWING HAS BEEN COMMENTED } \\
\text { OUT BECAUSE } \\
\text { * THERE EXISTS A FULL TABLE LOCK ON } \\
\text { THESE TWO } \\
\text { * TABLES. IF THIS IS A PROBLEM FOR THIS } \\
\text { KIND OF } \\
\text { * UPDATING OF A PKG ID IN THE FUTURE, } \\
\text { THIS WILL } \\
\text { * NEED TO BE RE-THOUGHT OUT. } \\
\text { UPDATE PROCADD } \\
\text { SET PROCADD_PKG_ID = NEW_PKG_ID } \\
\text { WHERE PROCADD_PKG_ID }=\text { OLD_PKG_ID; } \\
\text { UPDATE PROCLIST } \\
\text { SET PROC_PKG_ID }=\text { NEW_PKG_ID } \\
\text { WHERE PROC_PKG_ID }=\text { OLD_PKG_ID; } \\
\text { *I }\end{array}$ & v & \\
\hline
\end{tabular}




\title{
APPENDIX B INTERNAL CONTENTS COMPARED WITH EACH OTHER AND COMPARED TO APPENDIX C
}

\author{
General Category 1 design concern:
}

- Appendix $\mathrm{C}$ defines a METRICS table which is supposed to exist for the Facility Metrics reports $(1101,1102,1103,1104)$. Of the 11 data elements in this table, only 4 are used by these reports. Most of the data in the reports is apparently retrieved from the WASTE and CONLOC tables directly. If the METRIC table is used as implied, the access to the WASTE and CONLOC tables is via the MET_PKG_ID data element. The concept of a table to support reports should help address performance and update conflicts associated with real time reporting (see following bullet). However, it is apparent that the current METRIC table use is not yet defined.

- General design specifications stipulate an assumption that all data is available at report time from all data entry activities: in other words, "real time" access to "real time" data on line. While the system design is oriented around real time data entry, on line, the simultaneous overhead of trying to run reporting access against tables being updated can have an adverse affect on performance. Reports that can be run from "batch" information should be identified and used as much as possible (e.g. data retrieved from the data base at night, or from special report tables which are updated each night).

\section{General Category 2 design concerns:}

- Many reports react to user entry for waste types - not clear if report appears on screen for data entry, and then generates resultant query (need a "go" button?), or if query is entered on a separate report query screen and form then generates. There is no specification for menu selections to enter queries.

- Not clear if the reports are only available from the Report selection of the Main Menu or from within other Main Menu selections. For example, may be desirable to access shipping reports from within the Shipping menu.

- Various reports seem to use differing fonts. . For simplicity and standardization, should consider always using the same font type for all standard reports. 
- Many of the report samples field definitions show field displays with character lengths and decimal positions different than what is defined in the data dictionary (Appendix C). While it is understood that these are samples only, they should be revised to portray field displays as actually available. These can affect actual report layouts because of size and fit problems. Consequently, data envisioned to appear on single lines or grouped in certain ways for ease of use may not actually appear in a desirable manner on the final report. 


\begin{tabular}{|c|c|c|c|c|}
\hline REPORT & DESIGN CONTENT & DISCREPANCY & $\begin{array}{l}\text { RATIONALE FOR } \\
\text { CATEGORY }\end{array}$ & RESOLUTION \\
\hline \multicolumn{5}{|c|}{ CATEGORY 1 DISCREPANCIES } \\
\hline $\begin{array}{l}\text { R1102: Building Inventory } \\
\text { Report }\end{array}$ & $\begin{array}{l}\text { Waste Type column (noted as Waste } \\
\text { Type Description on report sample): } \\
\text { specification retrieves } 2 \text { and } 3 \\
\text { character fields for apparent display } \\
\text { of PRIWASTYPE and } \\
\text { SECWASTYPE table description } \\
\text { fields }\end{array}$ & $\begin{array}{l}\text { PRIWASTYPE and } \\
\text { SECWASTYPE description fields } \\
\text { are } 20 \text { and } 50 \text { characters, } \\
\text { respectively }\end{array}$ & $\begin{array}{l}\text { report display needs to be } \\
\text { reconsidered to ensure } \\
\text { correct data is retrieved }\end{array}$ & \multirow[t]{5}{*}{$\begin{array}{l}\text { All reporting to be finally } \\
\text { specified as a result of Phase } \\
2 / 3 \text { functional specification } \\
\text { review }\end{array}$} \\
\hline \multirow[t]{4}{*}{$\begin{array}{l}\text { R1201: Container Listing } \\
\text { Report for Package ID }\end{array}$} & Data Quality Code & $\begin{array}{l}\text { no specification to map this } \\
\text { heading to a specific data element }\end{array}$ & data retrieval may be wrong & \\
\hline & $\begin{array}{l}\text { specification describes a: Physical } \\
\text { State Code; } \\
\text { Organic Wt }(\mathrm{kg})\end{array}$ & $\begin{array}{l}\text { report sample is missing this } \\
\text { column heading and data display }\end{array}$ & \multirow[t]{2}{*}{$\begin{array}{l}\text { data retrieval may not } \\
\text { support report requirement }\end{array}$} & \\
\hline & $\begin{array}{l}\text { Backlog Flag column for display of } \\
\text { CON_BACKLOG_FLAG }\end{array}$ & $\begin{array}{l}\text { Appendix } \mathrm{C} \text { does contain this } \\
\text { data element }\end{array}$ & & \\
\hline & $\begin{array}{l}\text { report sample has Action Taken } \\
\text { column and Shipment Arrived }\end{array}$ & $\begin{array}{l}\text { specifications do not define these } \\
\text { columns or their related data } \\
\text { mapping }\end{array}$ & $\begin{array}{l}\text { report will have blank } \\
\text { fields }\end{array}$ & \\
\hline
\end{tabular}




\begin{tabular}{|c|c|c|c|c|}
\hline REPORT & DESIGN CONTENT & DISCREPANCY & $\begin{array}{l}\text { RATIONALE FOR } \\
\text { CATEGORY }\end{array}$ & RESOLUTION \\
\hline \multicolumn{5}{|c|}{ CATEGORY 2 DISCREPANCIES } \\
\hline $\begin{array}{l}\text { R0351: Transfer Drum } \\
\text { Status Report }\end{array}$ & $\begin{array}{l}\text { page break specified to occur "as } \\
\text { required" }\end{array}$ & $\begin{array}{l}\text { implies that page break will } \\
\text { occur as page fills (line } 66 \text { ?) - if } \\
\text { so, certain data groupings and } \\
\text { headings will be broken up }\end{array}$ & $\begin{array}{l}\text { should consider page breaks } \\
\text { to also occur at end of data } \\
\text { grouping }\end{array}$ & \multirow[t]{4}{*}{$\begin{array}{l}\text { All reporting to be finally } \\
\text { specified as a result of Phase } \\
2 / 3 \text { functional specification } \\
\text { review }\end{array}$} \\
\hline \multirow[t]{2}{*}{$\begin{array}{l}\text { R0501: Open Sample } \\
\text { Status Detail Report }\end{array}$} & $\begin{array}{l}\text { display needed for multiple sample } \\
\text { comments }\end{array}$ & $\begin{array}{l}\text { each comment field is } 255 \\
\text { characters - report will either } \\
\text { contain a great amount of "white } \\
\text { space" (where comments are } \\
\text { shorter than } 255 \text { characters), or } \\
\text { there will need to be truncation } \\
\text { rules for shortened displays of } \\
\text { large comment fields, or line } \\
\text { wrap with concatenation to use } \\
\text { just as much space as needed }\end{array}$ & $\begin{array}{l}\text { should have a user review } \\
\text { to decide on preferable } \\
\text { solution }\end{array}$ & \\
\hline & query for all open samples & $\begin{array}{l}\text { report will return all samples, } \\
\text { grouped in order by Package ID, } \\
\text { in a large print out - search for a } \\
\text { discreet sample will be difficult }\end{array}$ & $\begin{array}{l}\text { should consider permitting } \\
\text { user query on a single } \\
\text { Package ID and/or Sample } \\
\text { ID }\end{array}$ & \\
\hline $\begin{array}{l}\text { R1101: Empty Container } \\
\text { Inventory Report }\end{array}$ & $\begin{array}{l}\text { facility location shown in the } \\
\text { heading and for each discreet record }\end{array}$ & $\begin{array}{l}\text { since data grouped by Facility } \\
\text { Location, should simplify report } \\
\text { by only presenting data once: in } \\
\text { the heading }\end{array}$ & $\begin{array}{l}\text { may generate a "cluttered" } \\
\text { report }\end{array}$ & \\
\hline
\end{tabular}




\begin{tabular}{|c|c|c|c|c|}
\hline REPORT & DESIGN CONTENT & DISCREPANCY & $\begin{array}{l}\text { RATIONALE FOR } \\
\text { CATEGORY }\end{array}$ & RESOLUTION \\
\hline $\begin{array}{l}\text { R1102: Building Inventory } \\
\text { Report }\end{array}$ & $\begin{array}{l}\text { WRAP Location, Storage Category, } \\
\text { Container Use Code }\end{array}$ & $\begin{array}{l}\text { all three are shown in both report } \\
\text { heading and repeated again for } \\
\text { each record retrieved }\end{array}$ & \multirow{2}{*}{$\begin{array}{l}\text { since data is grouped } \\
\text { according to the heading } \\
\text { data, having the data in the } \\
\text { column display will be } \\
\text { redundant - should } \\
\text { eliminate need for column } \\
\text { display to simplify logic } \\
\text { and data retrieval }\end{array}$} & \\
\hline \multirow[t]{2}{*}{$\begin{array}{l}\text { R1104: WRAP Processing } \\
\text { Report }\end{array}$} & Container Use Code & $\begin{array}{l}\text { shown in both report heading and } \\
\text { repeated again for each record } \\
\text { retrieved }\end{array}$ & & \\
\hline & $\begin{array}{l}\text { Data Selects for start and end dates } \\
\text { of report }\end{array}$ & $\begin{array}{l}\text { no field specified for data entry } \\
\text { or logic comparisons - may be a } \\
\text { start date of CON_ACCUM_DT } \\
\text { and an end date of current } \\
\text { CONLOC_IOCN_DT? }\end{array}$ & $\begin{array}{l}\text { no way to bound report } \\
\text { logic for needed time } \\
\text { windows }\end{array}$ & $\begin{array}{l}\text { Update Appendix B - specify } \\
\text { user data bounds are on } \\
\text { CON_ACCUM_DT }\end{array}$ \\
\hline \multirow[t]{2}{*}{$\begin{array}{l}\text { R1201: Container Listing } \\
\text { Report for Package ID }\end{array}$} & $\begin{array}{l}\text { specifies a "calculated" Waste Type } \\
\text { Description }\end{array}$ & $\begin{array}{l}\text { use of "calculated" does not seem } \\
\text { clear - perhaps intention is to } \\
\text { "derive" SWTYP_DESCR from } \\
\text { SECWASTYPE table using } \\
\text { SWTYP_CD key }\end{array}$ & $\begin{array}{l}\text { data retrieval is not clearly } \\
\text { defined - this is actually a } \\
\text { lookup to SWTYP_DESCR } \\
\text { on SWTYP_CD key }\end{array}$ & $\begin{array}{l}\text { Update Appendix B - replace } \\
\text { "calculated" with } \\
\text { "SWTYP_DESCRP" for } \\
\text { "CON SWTYP_CD" }\end{array}$ \\
\hline & $\begin{array}{l}\text { Container Volume, } \\
\text { Container Empty Tare Wt, } \\
\text { Container Total Wt, } \\
\text { DW Waste \#, } \\
\text { Neutron Dose Rate }\end{array}$ & $\begin{array}{l}\text { Appendix } C \text { defines larger prime } \\
\text { number and different decimal } \\
\text { space storage requirements for } \\
\text { these fields than are being } \\
\text { allowed for on the report }\end{array}$ & $\begin{array}{l}\text { number truncation or } \\
\text { "round-off" rules need to } \\
\text { be defined if entire stored } \\
\text { numeric value is not to be } \\
\text { displayed }\end{array}$ & $\begin{array}{l}\text { All reporting to be finally } \\
\text { specified as a result of Phase } \\
2 / 3 \text { functional specification } \\
\text { review }\end{array}$ \\
\hline
\end{tabular}




\begin{tabular}{|c|c|c|c|c|}
\hline REPORT & DESIGN CONTENT & DISCREPANCY & $\begin{array}{l}\text { RATIONALE FOR } \\
\text { CATEGORY }\end{array}$ & RESOLUTION \\
\hline & $\begin{array}{l}\text { Generator Information, } \\
\text { Hazardous Package Detail }\end{array}$ & $\begin{array}{l}\text { shown on report sample as a } \\
\text { discreet field with a defined } \\
\text { character display area - shown in } \\
\text { screen definition as a heading for } \\
\text { data grouping }\end{array}$ & $\begin{array}{l}\text { data content is not clear - } \\
\text { either definition or report } \\
\text { sample is not accurate }\end{array}$ & \\
\hline & $\begin{array}{l}\text { specifies a "calculated" Company } \\
\text { Title }\end{array}$ & $\begin{array}{l}\text { use of "calculated" does not seem } \\
\text { clear - perhaps intention is to } \\
\text { "derive" CMPNY_TITLE from } \\
\text { COMPANY table using } \\
\text { CMPNY_ID key }\end{array}$ & $\begin{array}{l}\text { data retrieval is not clearly } \\
\text { defined }\end{array}$ & $\begin{array}{l}\text { Update Appendix B - replace } \\
\text { "calculated" with } \\
\text { "CMPNY_TITLE" for } \\
\text { "CON_CMPNY_ID" }\end{array}$ \\
\hline & $\begin{array}{l}\text { Total Alpha }(\mathrm{Ci}) \text {, } \\
\text { Total Beta-Gamma }(\mathrm{Ci}) \text {, } \\
\text { Dose Rate, } \\
\text { Total Pu Equivalent }(\mathrm{Ci}) \text {, } \\
\text { Thermal Power, } \\
\text { Alpha Ci, } \\
\text { PE-Ci, } \\
\text { PU-FGE } \\
\text { Isotope Activity }\end{array}$ & $\begin{array}{l}\text { Appendix C defines these as } \\
\text { FLOAT fields - no definition for } \\
\text { their display } \\
\end{array}$ & $\begin{array}{l}\text { need to define if these are } \\
\text { also "floating" sized fields } \\
\text { or if there are truncation or } \\
\text { "round-off" rules }\end{array}$ & \multirow[t]{2}{*}{$\begin{array}{l}\text { All reporting to be finally } \\
\text { specified as a result of Phase } \\
2 / 3 \text { functional specification } \\
\text { review }\end{array}$} \\
\hline & RSR report display & $\begin{array}{l}\text { fields have been condensed to } \\
\text { abbreviated headings and } \\
\text { shortened data element display } \\
\text { space }\end{array}$ & $\begin{array}{l}\text { need to reconsider need to } \\
\text { have all RSR report on one } \\
\text { line - not likely to fit - } \\
\text { perhaps a separate report? }\end{array}$ & \\
\hline
\end{tabular}




\begin{tabular}{|l|l|l|l|}
\hline REPORT & DESIGN CONTENT & DISCREPANCY & $\begin{array}{l}\text { RATIONALE FOR } \\
\text { CATEGORY }\end{array}$ \\
\hline & Schedule and Frequency & $\begin{array}{l}\text { Report has potential for large } \\
\text { volume and significant table } \\
\text { access; probable performance } \\
\text { impact during business hours }\end{array}$ & $\begin{array}{l}\text { should consider off-hour } \\
\text { batch generation and/or } \\
\text { work against special } \\
\text { refreshed report table }\end{array}$ \\
\cline { 2 - 4 } & Page Break & $\begin{array}{l}\text { defined as "as required" - will } \\
\text { likely break up data groupings } \\
\text { and column headings }\end{array}$ & $\begin{array}{l}\text { consider occurring at end of } \\
\text { each page I and end of data } \\
\text { for each CON_PKG_ID }\end{array}$ \\
\hline
\end{tabular}




\section{ARCHIVE/JOURNALING: ORACLE DATABASE TRIGGERS USED FOR JOURNALING}

\section{A. General V\&V Findings}

\section{Category 1 Discrepancy}

There are no requirements or specifications noted for archiving. Under the current implementation, the retention of journaled data, plus all other "closed out" records (such as for containers shipped from WRAP-1) will be retained indefinitely in the DMS system. This will eventually lead to obvious storage problems. An archiving set of specifications is required which will specify retention periods for types of data, batch or other routines for purging and saving this data, archiving mechanisms (tape, hard copy, separate disk, etc.), and the retention periods for archived data.

\section{Category 2 Discrepancy}

Database Triggers are defined for all phase 1 tables marked for journaling in the SDD. The SDD only defines which tables are journaled; it does not specify the logic to be used. Consequently, the following V\&V results should be reviewed by the system manager to ensure that what is happening is, in fact, the desired/required approach to the journaling for the DMS functionality.

\section{B. Description of Current Journaling Implementation}

\section{Table Structure In Support of Journaling}

The Journal is a set of ORACLE tables with all the columns that are in the journaled table, plus five additional columns. The Database Trigger journals all columns for a given table and updates these five additional columns:

$\begin{array}{ll}\text { OPERATION } & \text { The insert, update or delete operation. } \\ \text { DATETIME } & \text { The system date at time of journaling } \\ \text { ORACLE_USER } & \text { The ORACLE user logon. } \\ \text { COMMIT_USER } & \text { The commit user. } \\ \text { APPLN } & \text { The application performing the insert, update or delete. }\end{array}$


A Journal Table will have the same name of the table it is making journal changes to, plus the suffix 'JN'. The following tables each have a Database Trigger and a Joumal Table to handle journaling:

$\begin{array}{ll}\text { APPMSDS } & \text { CHEMCOMP } \\ \text { COC } & \text { CONLOC } \\ \text { CONREL } & \text { HAZDETAIL } \\ \text { ISOQTY } & \text { PHYSCOMP } \\ \text { PKGDW } & \text { PROCADD } \\ \text { RADDETAIL } & \text { RADMAT } \\ \text { SAMPLE } & \text { SAMREL } \\ \text { SAR } & \text { SHIPWRAP } \\ \text { TREATPROC } & \text { USERS } \\ \text { WASTE } & \text { WASTEXT }\end{array}$

2. Database Triggers

The Database Triggers are activated whenever an insert, update or delete operation occurs on a table which has a trigger. All of the Database Triggers perform these functions:

- For insert or update operations, the new data is written to the table and the journal.

- For delete operations, the old data is written to the journal and the old data is deleted from the table.

The Database Trigger for the CONLOC table has this additional functionality:

- If inserting and NEW.CONLOC_LOCN_ID='AS_RS' and NEW.CONLOC_PKG_ID not in PROCLIST, then NEW.CONLOC_PKG_ID is inserted into NOTPROCLIST.

- If updating and OLD.CONLOC_LOCN_ID='AS_RS' then delete from NOTPROCLIST for NOTPROC PKG ID =OLD.CONLOC_PKG_ID. If NEW.CONLOC_LOCN_ID $=$ 'AS_RS' and NEW.CONLOC_LOCN_ID not in PROCLIST then NEW.CONLOC_PKG_ID is inserted into NOTPROCLIST. 
- If deleting and OLD.CONLOC_LOCN_ID='AS_RS' then delete from NOTPROCLIST for NOTPROC__PKG_ID =OLD.CONLOC_PKG_ID.

\section{Journaling In Support of Auditing}

The journaling strategy can be awkward for auditing purposes. For example, to examine a row's previous contents for a given primary key, the auditor must:

1. Determine the oldest operation for a given primary key.

2. If the oldest operation was insert, the row previously did not exist.

3. If the oldest operation was update, retrieve the next oldest row for a given primary key.

4. - If the oldest operation was delete, retrieve the oldest row for a given primary key. 


\begin{tabular}{|c|c|c|c|}
\hline $\begin{array}{c}\text { DESIGN FEATURE } \\
\mathbf{A}\end{array}$ & DESIGN FEATURE B & DISCREPANCY & $\begin{array}{l}\text { RATIONALE FOR } \\
\text { CATEGORY }\end{array}$ \\
\hline \multicolumn{4}{|c|}{ CATEGORY 3 DISCREPANCIES FOR ALL SDD REVIEW MATRICES } \\
\hline \multirow{6}{*}{$\begin{array}{l}\text { Report DMSR0351: } \\
\text { Transfer Drum Status } \\
\text { Report }\end{array}$} & $\begin{array}{l}\text { screen definition: column heading of } \\
\text { Waste Type }\end{array}$ & $\begin{array}{l}\text { screen sample breaks into two } \\
\text { fields }\end{array}$ & $\begin{array}{l}\text { sample and specification are not } \\
\text { consistent }\end{array}$ \\
\hline & $\begin{array}{l}\text { screen sample for display of Drum } \\
\text { Status shows } 1 \text { character field }\end{array}$ & $\begin{array}{l}\text { Appendix } C \text { defines data element } \\
\text { with } 2 \text { characters }\end{array}$ & $\begin{array}{l}\text { sample display inconsistent with } \\
\text { data dictionary }\end{array}$ \\
\hline & $\begin{array}{l}\text { screen definition: Drum Status } \\
\text { contains } \\
\text { CONEXT_CNTNR_STATUS }\end{array}$ & $\begin{array}{l}\text { field name is } \\
\text { CONEXT_CNTR_STATUS }\end{array}$ & $\begin{array}{l}\text { typo: should be corrected in } \\
\text { definition }\end{array}$ \\
\hline & $\begin{array}{l}\text { screen definition: column heading of } \\
\text { WRAP Location }\end{array}$ & $\begin{array}{l}\text { screen sample shows Drum } \\
\text { Location. }\end{array}$ & \multirow[t]{3}{*}{$\begin{array}{l}\text { sample and specification are not } \\
\text { consistent }\end{array}$} \\
\hline & $\begin{array}{l}\text { screen definition: column heading of } \\
\text { Location Date }\end{array}$ & $\begin{array}{l}\text { screen sample shows two fields: } \\
\text { date and time }\end{array}$ & \\
\hline & $\begin{array}{l}\text { screen definition: column heading of } \\
\text { Inner Package PINs }\end{array}$ & $\begin{array}{l}\text { screen sample shows Inner } \\
\text { Package ID }\end{array}$ & \\
\hline \multirow[t]{2}{*}{$\begin{array}{l}\text { Report DMSR1101: } \\
\text { Empty Container } \\
\text { Inventory Report }\end{array}$} & Facility Receipt Date definition & $\begin{array}{l}\text { typos: RECKCK for RECDCK } \\
\text { missing "e" in receipt for } \\
\text { clarity: move close paren } \\
\text { outside of } 2 \text { nd RECDCK }\end{array}$ & $\begin{array}{l}\text { typos: should be corrected in } \\
\text { definition }\end{array}$ \\
\hline & $\begin{array}{l}\text { screen definition: column heading of } \\
\text { WRAP Location }\end{array}$ & $\begin{array}{l}\text { screen sample shows Facility } \\
\text { Location }\end{array}$ & $\begin{array}{l}\text { sample and specification are not } \\
\text { consistent }\end{array}$ \\
\hline
\end{tabular}

\section{RESOLUTION}

To be resolved with publication of new "asbuilt" ADD revision. Discrepancy Item Closed 


\begin{tabular}{|c|c|c|c|c|}
\hline $\begin{array}{l}\text { DESIGN FEATURE } \\
\text { A }\end{array}$ & DESIGN FEATURE B & DISCREPANCY & $\begin{array}{l}\text { RATIONALE FOR } \\
\text { CATEGORY }\end{array}$ & RESOLUTION \\
\hline & $\begin{array}{l}\text { screen sample for display of WRAP } \\
\text { Location shows } 9 \text { character field }\end{array}$ & $\begin{array}{l}\text { Appendix } C \text { defines data element } \\
\text { with } 10 \text { characters }\end{array}$ & \multirow{6}{*}{$\begin{array}{l}\text { sample display inconsistent with } \\
\text { data dictionary } \\
\text { sample and specifications are not } \\
\text { consistent }\end{array}$} & \multirow{9}{*}{. } \\
\hline & $\begin{array}{l}\text { screen definition: column heading of } \\
\text { Facility Location }\end{array}$ & $\begin{array}{l}\text { screen sample shows Container } \\
\text { Location }\end{array}$ & & \\
\hline \multirow{5}{*}{$\begin{array}{l}\text { Report DMSR1103: } \\
\text { Waste Package } \\
\text { Location History } \\
\text { Report }\end{array}$} & $\begin{array}{l}\text { screen definition: column heading of } \\
\text { Package ID }\end{array}$ & $\begin{array}{l}\text { screen sample shows Waste } \\
\text { Container ID }\end{array}$ & & \\
\hline & $\begin{array}{l}\text { screen definition: column heading of } \\
\text { Facility Location }\end{array}$ & $\begin{array}{l}\text { screen sample shows WRAP } \\
\text { Location }\end{array}$ & & \\
\hline & $\begin{array}{l}\text { screen definition: column heading of } \\
\text { WRAP Relocation Date }\end{array}$ & $\begin{array}{l}\text { screen sample shows Relocation } \\
\text { Date }\end{array}$ & & \\
\hline & $\begin{array}{l}\text { screen definition: no column heading } \\
\text { of Relocation Time }\end{array}$ & $\begin{array}{l}\text { screen sample shows Relocation } \\
\text { Time }\end{array}$ & & \\
\hline & $\begin{array}{l}\text { screen definition: Sort Sequence } \\
\text { specifies CONOC_DT }\end{array}$ & field name is CONLOC_DT & $\begin{array}{l}\text { typo: should be corrected in } \\
\text { definition }\end{array}$ & \\
\hline \multirow[t]{2}{*}{$\begin{array}{l}\text { Report DMSR1104: } \\
\text { WRAP Processing } \\
\text { Report }\end{array}$} & $\begin{array}{l}\text { WASTE Type in heading: sample } \\
\text { shows actual field names as } \\
\text { examples for users to follow when } \\
\text { doing data entry }\end{array}$ & $\begin{array}{l}\text { actual field names are often of } \\
\text { little meaning to most users }\end{array}$ & $\begin{array}{l}\text { should consider using examples of } \\
\text { "typical" data such as is used for } \\
\text { Container Use Code }\end{array}$ & \\
\hline & $\begin{array}{l}\text { screen definition: column heading of } \\
\text { Total: Containers Verified }\end{array}$ & $\begin{array}{l}\text { screen sample shows Total: } \\
\text { Containers Certified }\end{array}$ & $\begin{array}{l}\text { sample and specification are not } \\
\text { consistent }\end{array}$ & \\
\hline
\end{tabular}




\begin{tabular}{|c|c|c|c|c|}
\hline $\begin{array}{l}\text { DESIGN FEATURE } \\
\text { A }\end{array}$ & DESIGN FEATURE B & DISCREPANCY & $\begin{array}{l}\text { RATYONALE FOR } \\
\text { CATEGORY }\end{array}$ & RESOLUTYON \\
\hline \multirow[t]{7}{*}{$\begin{array}{l}\text { Report DMSR1201: } \\
\text { Container Listing } \\
\text { Report for Package ID }\end{array}$} & $\begin{array}{l}\text { screen sample for display of SDAR } \\
\text { Approval Number shows } 12 \\
\text { character field }\end{array}$ & $\begin{array}{l}\text { Appendix } C \text { defines data element } \\
\text { with } 14 \text { characters }\end{array}$ & \multirow[t]{4}{*}{$\begin{array}{l}\text { sample display inconsistent with } \\
\text { data dictionary }\end{array}$} & \multirow{7}{*}{. } \\
\hline & $\begin{array}{l}\text { screen sample for display of } \\
\text { Secondary Waste Group shows } 2 \\
\text { character field }\end{array}$ & $\begin{array}{l}\text { Appendix } C \text { defines data element } \\
\text { with } 3 \text { characters }\end{array}$ & & \\
\hline & $\begin{array}{l}\text { screen sample for display of } \\
\text { Container Description shows } 12 \\
\text { character field }\end{array}$ & $\begin{array}{l}\text { Appendix } C \text { defines data element } \\
\text { with } 14 \text { characters }\end{array}$ & & \\
\hline & $\begin{array}{l}\text { screen sample for display of } \\
\text { Container Contents is deficient }\end{array}$ & $\begin{array}{l}\text { Appendix } C \text { indicates need to } \\
\text { display } 255 \text { characters }\end{array}$ & & \\
\hline & $\begin{array}{l}\text { screen definition: column heading of } \\
\text { Generating Company/Company Title }\end{array}$ & $\begin{array}{l}\text { screen sample does not show } \\
\text { Title in column heading, } \\
\text { although field layout indicates } \\
\text { apparent space for display }\end{array}$ & \multirow[t]{3}{*}{$\begin{array}{l}\text { sample and specification are not } \\
\text { consistent }\end{array}$} & \\
\hline & $\begin{array}{l}\text { screen sample for display of } \\
\text { Organization shows } 5 \text { character field }\end{array}$ & $\begin{array}{l}\text { Appendix } \mathrm{C} \text { defines data element } \\
\text { with } 8 \text { characters }\end{array}$ & & \\
\hline & $\begin{array}{l}\text { screen sample for display of Source } \\
\text { Facility shows } 8 \text { character field }\end{array}$ & $\begin{array}{l}\text { Appendix } \mathbf{C} \text { defines data element } \\
\text { with } 11 \text { characters }\end{array}$ & & \\
\hline
\end{tabular}




\begin{tabular}{|c|c|c|c|c|}
\hline $\begin{array}{l}\text { DESIGN FEATURE } \\
\text { A }\end{array}$ & DESIGN FEATURE B & DISCREPANCY & $\begin{array}{l}\text { RATIONALE FOR } \\
\text { CATEGORY }\end{array}$ & RESOLUTION \\
\hline & $\begin{array}{l}\text { screen sample for display of Charge } \\
\text { Code shows } 4 \text { character field }\end{array}$ & $\begin{array}{l}\text { Appendix } C \text { defines data element } \\
\text { with } 8 \text { characters }\end{array}$ & & \\
\hline & $\begin{array}{l}\text { screen sample for display of } \\
\text { Generator Comments is deficient }\end{array}$ & $\begin{array}{l}\text { Appendix } C \text { indicates need to } \\
\text { display } 255 \text { characters }\end{array}$ & & \\
\hline & $\begin{array}{l}\text { screen sample for display of } \\
\text { Designation Code shows } 2 \text { character } \\
\text { field. }\end{array}$ & $\begin{array}{l}\text { Appendix } C \text { defines data element } \\
\text { with } 3 \text { characters }\end{array}$ & & \\
\hline & $\begin{array}{l}\text { screen sample for display of } \\
\text { Flashpoint shows } 4 \text { character field }\end{array}$ & \multirow[t]{2}{*}{$\begin{array}{l}\text { Appendix } C \text { defines data element } \\
\text { with } 6 \text { characters }\end{array}$} & & \\
\hline & $\begin{array}{l}\text { screen sample for display of } \\
\text { Hazardous Properties Cd shows } 2 \\
\text { character field }\end{array}$ & & & \\
\hline & $\begin{array}{l}\text { screen sample for display of } \\
\text { LandBan shows } 2 \text { character field }\end{array}$ & $\begin{array}{l}\text { Appendix } \mathrm{C} \text { defines data element } \\
\text { with } 17 \text { characters }\end{array}$ & & \\
\hline & $\begin{array}{l}\text { screen sample for display of } \\
\text { numbered LandBan fields shows } 2 \\
\text { character field }\end{array}$ & $\begin{array}{l}\text { Appendix } \mathrm{C} \text { defines data element } \\
\text { with } 8 \text { characters }\end{array}$ & & \\
\hline & $\begin{array}{l}\text { screen sample for display of Assay } \\
\text { Number shows } 12 \text { character field }\end{array}$ & $\begin{array}{l}\text { Appendix } C \text { defines data element } \\
\text { with } 14 \text { characters }\end{array}$ & & \\
\hline
\end{tabular}




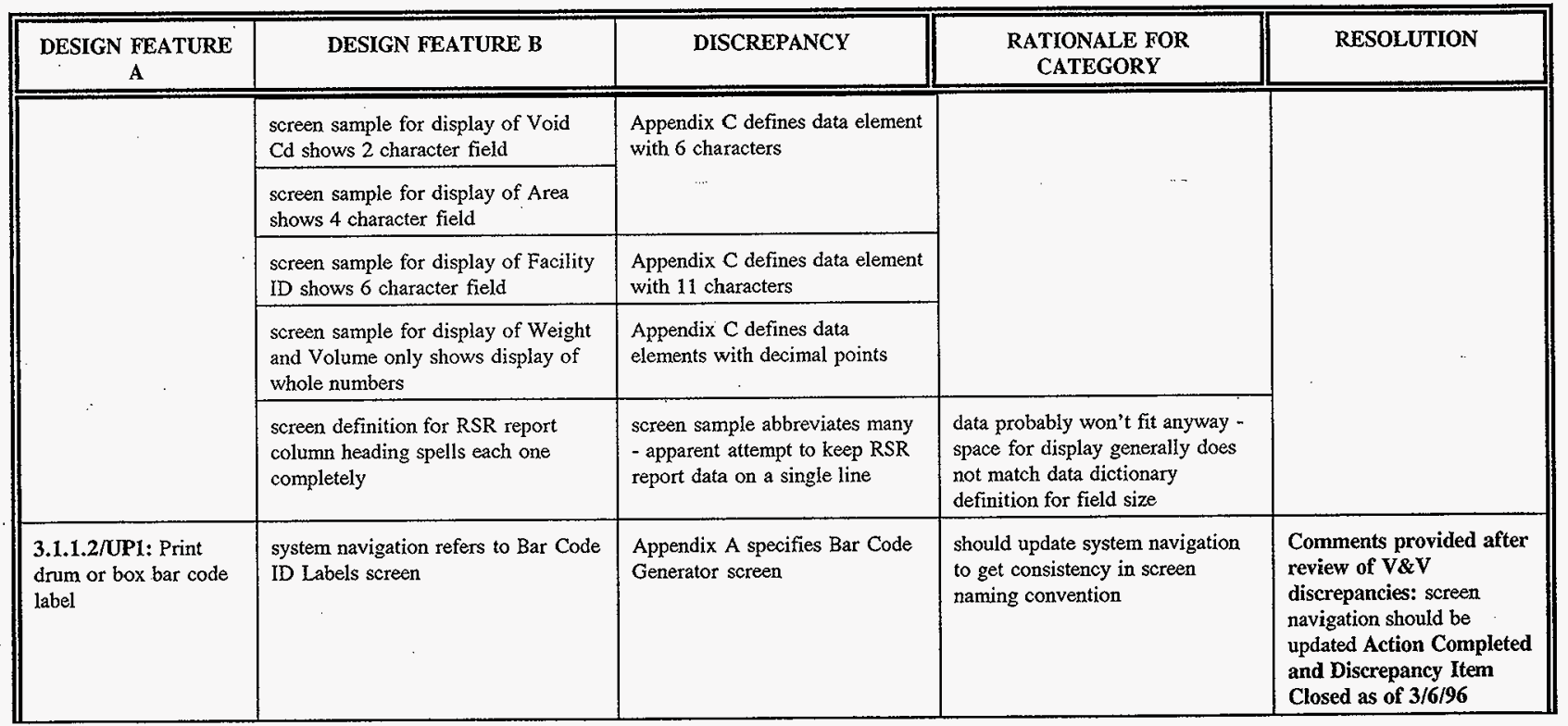




\begin{tabular}{|c|c|c|c|c|}
\hline $\begin{array}{l}\text { DESIGN FEATURE } \\
\text { A }\end{array}$ & DESIGN FEATURE B & DISCREPANCY & $\begin{array}{l}\text { RATIONALE FOR } \\
\text { CATEGORY }\end{array}$ & RESOLUTION \\
\hline $\begin{array}{l}\text { 3.1.1.2/UP2: Receive } \\
\text { Drum or boxes }\end{array}$ & $\begin{array}{l}\text { system navigation refers to using } \\
\text { data for comparison to shipping } \\
\text { papers }\end{array}$ & $\begin{array}{l}\text { Appendix } F \text { makes no reference } \\
\text { to shipping paper interaction }\end{array}$ & $\begin{array}{l}\text { presumed to be a manual process } \\
\text { outside of system - dependent on } \\
\text { administrative processes - } \\
\text { Appendix F should make } \\
\text { reference to this interaction with } \\
\text { the system to clarify that the } \\
\text { shipping papers are not required } \\
\text { from the system }\end{array}$ & $\begin{array}{l}\text { Comments provided after } \\
\text { review of V\&V } \\
\text { discrepancies: screen } \\
\text { navigation should be } \\
\text { updated Action Completed } \\
\text { and Discrepancy Item } \\
\text { Closed as of } 3 / 6 / 96\end{array}$ \\
\hline $\begin{array}{l}\text { 3.1.2.1/UP4: Physical } \\
\text { Composition Record } \\
\text { pop-up }\end{array}$ & $\begin{array}{l}\text { Appendix F condition/event } \\
\text { specification states "PIN } \\
\text { PHYS_PKG_ID" }\end{array}$ & $\begin{array}{l}\text { word "PIN" in pseudo-code is } \\
\text { either a typo or poorly placed in } \\
\text { text string }\end{array}$ & $\begin{array}{l}\text { should be reworded/corrected for } \\
\text { clarity }\end{array}$ & $\begin{array}{l}\text { Comments provided after } \\
\text { review of } Y \& V \\
\text { discrepancies: decision: } \\
\text { may be redundant but not } \\
\text { harmful - no action }\end{array}$ \\
\hline $\begin{array}{l}\text { 3.1.2.2/UP1-2: NDA } \\
\text { Data Review in the } \\
\text { Control Room }\end{array}$ & $\begin{array}{l}\text { Appendix A screen print shows } \\
\text { "NDE results" }\end{array}$ & screen supports NDA operations & $\begin{array}{l}\text { should change screen display } \\
\text { example }\end{array}$ & $\begin{array}{l}\text { Comments provided after } \\
\text { review of V\&V } \\
\text { discrepancies: screen has } \\
\text { been implemented correctly } \\
\text { - new screen print should } \\
\text { be included in Appendix A } \\
\text { Action Completed and } \\
\text { Discrepancy Item Closed } \\
\text { as of } 5 / 17 / 96\end{array}$ \\
\hline
\end{tabular}




\begin{tabular}{|c|c|c|c|c|}
\hline $\begin{array}{l}\text { DESIGN FEATURE } \\
\text { A }\end{array}$ & DESIGN FEATURE B & DISCREPANCY & $\begin{array}{l}\text { RATIONALE FOR } \\
\text { CATEGORY }\end{array}$ & RESOLUTION \\
\hline $\begin{array}{l}\text { 3.1.3.1/UP1: Glovebox } \\
\text { Drum Status at Entry }\end{array}$ & $\begin{array}{l}\text { system navigation discussion refers } \\
\text { to display of PIN of the inner drum }\end{array}$ & $\begin{array}{l}\text { Appendix A screen print and } \\
\text { Appendix F UP specify display } \\
\text { of both inner and outer drum } \\
\text { PIN }\end{array}$ & $\begin{array}{l}\text { should update system navigation } \\
\text { discussion for sake of } \\
\text { completeness }\end{array}$ & $\begin{array}{l}\text { Comments provided after } \\
\text { V\&V Review: need to } \\
\text { update SDD para } 5.2 .4 .3\end{array}$ \\
\hline $\begin{array}{l}\text { 3.1.3.1/UP3: LLWW } \\
\text { Non-Compliant Packet }\end{array}$ & $\begin{array}{l}\text { Appendix } F \text { specifies column header } \\
\text { name "PIN" }\end{array}$ & $\begin{array}{l}\text { Appendix A screen print shows } \\
\text { "Packet PIN" }\end{array}$ & $\begin{array}{l}\text { should update Appendix } \mathrm{F} \text { column } \\
\text { name for consistency }\end{array}$ & \multirow{2}{*}{$\begin{array}{l}\text { Comments provided after } \\
\text { review of V\&V } \\
\text { discrepancies: Appendix F } \\
\text { should be updated } \\
\text { Action Completed and } \\
\text { Discrepancy Item Closed } \\
\text { as of } 3 / 6 / 96\end{array}$} \\
\hline $\begin{array}{l}\text { 3.1.3.1/UP6: LLW } \\
\text { Exit Glovebox Product } \\
\text { Drum Update }\end{array}$ & $\begin{array}{l}\text { Appendix F specifies use of } \\
\text { CONEXT_WGT in estimated gross } \\
\text { weight calculation }\end{array}$ & $\begin{array}{l}\text { Appendix } F \text { attributes specify } \\
\text { CONEXT_FILLER_WGT which } \\
\text { is in Appendix C WASTEXT } \\
\text { table }\end{array}$ & $\begin{array}{l}\text { should update Appendix F } \\
\text { calculation reference }\end{array}$ & \\
\hline
\end{tabular}




\begin{tabular}{|c|c|c|c|c|}
\hline $\begin{array}{l}\text { DESIGN FEATURE } \\
\text { A }\end{array}$ & DESIGN FEATURE B & DISCREPANCY & $\begin{array}{l}\text { RATIONALE FOR } \\
\text { CATEGORY }\end{array}$ & RESOLUTION \\
\hline $\begin{array}{l}\text { LLW RWM Process } \\
\text { Glovebox Menu }\end{array}$ & $\begin{array}{l}\text { system navigation describes selection } \\
\text { of LLW RWM Process Glovebox } \\
\text { from Glovebox Operations Menu to } \\
\text { provide access to: } \\
\text { LLW RWM Waste Sorting } \\
\text { LLW RWM Compliant Waste } \\
\text { Load Out } \\
\text { LLW RWM Treatment Item } \\
\text { Assembly }\end{array}$ & $\begin{array}{l}\text { Appendix A hierarchy shows a } \\
\text { Process Ops menu selection } \\
\text { from the Main Menu, which } \\
\text { provides LLW RWM Glovebox } \\
\text { selection - then access provided } \\
\text { to Sorting and Compliant } \\
\text { screens - however, Treatment } \\
\text { Item Assembly seems to be } \\
\text { superseded by Treatment and } \\
\text { Treatment Loadout screen } \\
\text { selections } \\
\text { for other screens in LLW RWM } \\
\text { module: frequent inconsistency } \\
\text { in screen naming across system } \\
\text { navigation, Appendix A, and } \\
\text { Appendix F }\end{array}$ & $\begin{array}{l}\text { Appendix } A \text { is out of sync with } \\
\text { System Navigation description }\end{array}$ & \multirow[t]{2}{*}{$\begin{array}{l}\text { To be revised with } \\
\text { publication of new "as- } \\
\text { built" SDD revision. } \\
\text { Discrepancy Item Closed }\end{array}$} \\
\hline $\begin{array}{l}\text { 3.1.3.2/UP1: } \\
\text { LLWRWM Glovebox } \\
\text { Operations - } \\
\text { Accumulation of Waste } \\
\text { at Sample Station Area }\end{array}$ & $\begin{array}{l}\text { Appendix F specifies use of } \\
\text { CON_PKG_FROM_ID }\end{array}$ & $\begin{array}{l}\text { field name is } \\
\text { CONR_FROM_PKG_ID }\end{array}$ & typo: need to update Appendix F & \\
\hline
\end{tabular}




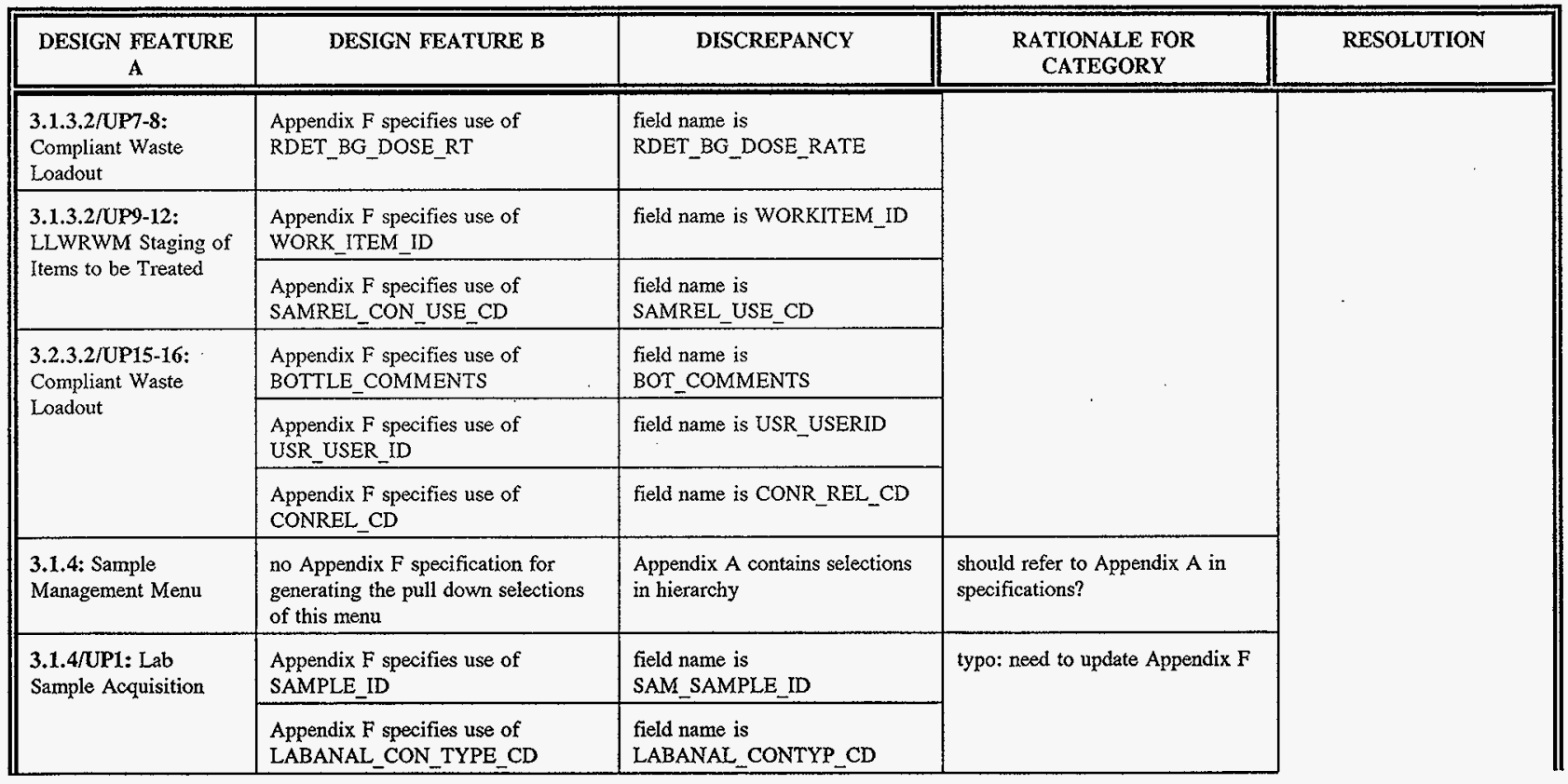




\begin{tabular}{|c|c|c|c|c|}
\hline $\begin{array}{l}\text { DESIGN FEATURE } \\
\text { A }\end{array}$ & DESIGN FEATURE B & DISCREPANCY & $\begin{array}{l}\text { RATIONALE FOR } \\
\text { CATEGORY }\end{array}$ & RESOLUTION \\
\hline $\begin{array}{l}\text { 3.1.4/UP2-3: Purge } \\
\text { Port Inventory Listing }\end{array}$ & $\begin{array}{l}\text { Appendix } F \text { specifies use of } \\
\text { COMMUNICATION }\end{array}$ & $\begin{array}{l}\text { Appendix } C \text { has table name of } \\
\text { COMMUNICATION_TABLE }\end{array}$ & $\begin{array}{l}\text { typo: need to update either } \\
\text { Appendix } F \text { or Appendix } C\end{array}$ & \\
\hline $\begin{array}{l}\text { 3.1.4/UP6-7: Field } \\
\text { Screening and data } \\
\text { input to support } \\
\text { verification of waste } \\
\text { data or taking of lab } \\
\text { samples }\end{array}$ & $\begin{array}{l}\text { Appendix } F \text { specifies use of } \\
\text { EIELD_ANAL_RES }\end{array}$ & field name is FIELD_RES & typo: need to update Appendix $F$ & \\
\hline \multirow{2}{*}{$\begin{array}{l}\text { 3.1.4/UP10-11: } \\
\text { Designation of packet } \\
\text { waste characteristics in } \\
\text { support of generation } \\
\text { of the worksheet } \\
\text { info/future treatment }\end{array}$} & $\begin{array}{l}\text { Appendix } F \text { specifies data store } \\
\text { named HDET. }\end{array}$ & table name is HAZDETAIL & . & \\
\hline & $\begin{array}{l}\text { system navigation requires selection } \\
\text { of } 0505 \text { from Sample Management } \\
\text { Menu }\end{array}$ & $\begin{array}{l}\text { Appendix } F \text { specifies selection } \\
\text { from screen } 0506 \text { and } 1221\end{array}$ & $\begin{array}{l}\text { need to update system navigation } \\
\text { description - out of sync with } \\
\text { final design }\end{array}$ & \\
\hline $\begin{array}{l}\text { 3.1.4/UP14-15: } \\
\text { Display packets } \\
\text { available for treatment } \\
\text { on a pop-up screen }\end{array}$ & $\begin{array}{l}\text { Appendix F specifies use of } \\
\text { MAT_GRP_CD }\end{array}$ & field name is MATL_GRP_CD & typo: need to update Appendix F & \\
\hline $\begin{array}{l}\text { 3.1.4/UP19-21: } \\
\text { Custody tracking once } \\
\text { samples are removed } \\
\text { from the glovebox }\end{array}$ & $\begin{array}{l}\text { Appendix } F \text { specifies data store } \\
\text { named LABORATORY }\end{array}$ & $\begin{array}{l}\text { Appendix } C \text { has table name of } \\
\mathrm{LAB}\end{array}$ & $\begin{array}{l}\text { typo: need to update Appendix } F \\
\text { or Appendix } C\end{array}$ & \\
\hline
\end{tabular}




\begin{tabular}{|c|c|c|c|c|}
\hline $\begin{array}{l}\text { DESIGN FEATURE } \\
\text { A }\end{array}$ & DESIGN FEATURE B & DISCREPANCY & $\begin{array}{l}\text { RATIONALE FOR } \\
\text { CATEGORY }\end{array}$ & RESOLUTION \\
\hline $\begin{array}{l}\text { 3.1.4/UP22-23: } \\
\text { Printing of Sample } \\
\text { Labels for Sample } \\
\text { Bottles }\end{array}$ & $\begin{array}{l}\text { system navigation specifies selection } \\
\text { of } 0508 \text { from Sample Management } \\
\text { Menu }\end{array}$ & $\begin{array}{l}\text { Appendix F selects } 0508 \text { from } \\
\text { both Sample Management Menu } \\
\text { and screen } 0504\end{array}$ & $\begin{array}{l}\text { system navigation out of sync } \\
\text { with final design }\end{array}$ & \multirow{7}{*}{. } \\
\hline \multirow{3}{*}{$\begin{array}{l}\text { 3.1.4/UP24: } \\
\text { Completion of } \\
\text { sample/bottle tracking } \\
\text { data (generally upon } \\
\text { retum of samples to } \\
\text { WRAP) }\end{array}$} & $\begin{array}{l}\text { Appendix } F \text { specifies use of } \\
\text { BOT_RETURNED_DT }\end{array}$ & $\begin{array}{l}\text { field name is } \\
\text { BOT_RETURN_DT }\end{array}$ & \multirow[t]{3}{*}{ typo: need to update Appendix F } & \\
\hline & $\begin{array}{l}\text { Appendix F specifies use of } \\
\text { SAMREL_DATE }\end{array}$ & field name is SAMREL_DT & & \\
\hline & $\begin{array}{l}\text { Appendix F specifies use of } \\
\text { CONREL_DT }\end{array}$ & field name is CONR_DT & & \\
\hline $\begin{array}{l}\text { 3.1.4/UP25: Update } \\
\text { purge port or pig } \\
\text { location }\end{array}$ & $\begin{array}{l}\text { system navigation specifies selection } \\
\text { of } 0510 \text { from Sample Management } \\
\text { Menu }\end{array}$ & $\begin{array}{l}\text { Appendix F specifies selection } \\
\text { from Main Menu - Main Menu } \\
\text { does provide Sample } \\
\text { Management Menu, but specs } \\
\text { imply screen is a Main Menu } \\
\text { discreet selection }\end{array}$ & $\begin{array}{l}\text { Appendix } F \text { description probably } \\
\text { needs to be brought in line with } \\
\text { system navigation }\end{array}$ & \\
\hline \multirow{2}{*}{$\begin{array}{l}\text { 3.1.4/UP26: Log-in } \\
\text { returned pigs, purge } \\
\text { ports, and samples }\end{array}$} & $\begin{array}{l}\text { Appendix F specifies use of } \\
\text { SAMR_BOTTLE_ID }\end{array}$ & $\begin{array}{l}\text { field name is } \\
\text { SAMREL_BOTTLE_ID }\end{array}$ & \multirow[t]{2}{*}{ typo: need to update Appendix $F$} & \\
\hline & $\begin{array}{l}\text { Appendix F specifies use of } \\
\text { SAMR_PKG_ID }\end{array}$ & $\begin{array}{l}\text { field name is } \\
\text { SAMREL_PKG_ID }\end{array}$ & & \\
\hline
\end{tabular}




\begin{tabular}{|c|c|c|c|c|}
\hline $\begin{array}{l}\text { DESIGN FEATURE } \\
\text { A }\end{array}$ & DESIGN FEATURE B & DISCREPANCX & $\begin{array}{l}\text { RATIONALE FOR } \\
\text { CATEGORY }\end{array}$ & RESOLUTION \\
\hline \multirow[t]{3}{*}{$\begin{array}{l}\text { 3.1.5/UP11: DMS to } \\
\text { transmit all applicable } \\
\text { SWITS data to SWITS } \\
\text { for drums sent to the } \\
\text { Processing Area in } \\
\text { WRAP }\end{array}$} & $\begin{array}{l}\text { Appendix } F \text { specifies HDET( }(S) \text { and } \\
\text { HDET }\end{array}$ & $\begin{array}{l}\text { table name is (S)HAZDETAIL } \\
\text { and HAZDETAIL }\end{array}$ & typo: need to correct Appendix F & $\begin{array}{l}\text { Comments provided after } \\
\text { review of V\&V } \\
\text { discrepancies: Appendix F } \\
\text { should be updated } \\
\text { Action Completed and } \\
\text { Discrepancy Item Closed } \\
\text { as of } 3 / 6 / 96 \\
\end{array}$ \\
\hline & $\begin{array}{l}\text { screen } 0602 \text { described as being for } \\
\text { drums sent to the Processing Area in } \\
\text { WRAP }\end{array}$ & $\begin{array}{l}\text { wording implies this is for } \\
\text { drums received rather than } \\
\text { shipped - could refer to drums } \\
\text { previously sent to processing? }\end{array}$ & $\begin{array}{l}\text { need to confirm intent of UP - } \\
\text { may need to update semantics or } \\
\text { change wording }\end{array}$ & \multirow[t]{2}{*}{$\begin{array}{l}\text { To be revised with } \\
\text { publication of new "as- } \\
\text { built" SDD revision. } \\
\text { Discrepancy Item Closed }\end{array}$} \\
\hline & $\begin{array}{l}\text { UP } 11 \text { and UP } 12 \text { only describe } \\
\text { drum processing }\end{array}$ & $\begin{array}{l}\text { cite use of CONEXT_USE_CD } \\
\text { which also includes boxes }\end{array}$ & need to update terminology & \\
\hline
\end{tabular}




\begin{tabular}{|c|c|c|c|c|}
\hline $\begin{array}{l}\text { DESIGN FEATURE } \\
\text { A }\end{array}$ & DESIGN FEATURE B & DISCREPANCY & $\begin{array}{c}\text { RATIONALE FOR } \\
\text { CATEGORY } \\
\end{array}$ & RESOLUTION \\
\hline $\begin{array}{l}\text { 3.1.5/UP12: DMS to } \\
\text { transmit all applicable } \\
\text { SWITS data to SWITS } \\
\text { for all drums received } \\
\text { by WRAP } \\
\text { 3.1.5/UP20: DMS to } \\
\text { transmit all applicable } \\
\text { SWITS data to SWITS } \\
\text { for all boxes and } \\
\text { empty drums received } \\
\text { by WRAP }\end{array}$ & $\begin{array}{l}\text { Appendix F specifies a location code } \\
\text { of TRANSIT }\end{array}$ & code is named IN_TRANSIT & \multirow[t]{2}{*}{ typo: need to correct Appendix F } & \\
\hline $\begin{array}{l}\text { 3.1.5/UP14: Update of } \\
\text { PCS database and } \\
\text { adjust radiologic } \\
\text { inventory for facility } \\
\text { 3.1.5/UP22: Update of } \\
\text { PCS database and } \\
\text { adjust radiologic } \\
\text { inventory for the } \\
\text { facility }\end{array}$ & $\begin{array}{l}\text { Appendix F specifies } \\
\text { RADMAT_RAT_TOTAL }\end{array}$ & $\begin{array}{l}\text { data element name is } \\
\text { RADMAT_RAD_TOT }\end{array}$ & & \\
\hline
\end{tabular}




\begin{tabular}{|c|c|c|c|c|}
\hline $\begin{array}{l}\text { DESIGN FEATURE } \\
\text { A }\end{array}$ & DESIGN FEATURE B & DISCREPANCY & $\begin{array}{l}\text { RATIONALE FOR } \\
\text { CATEGORY }\end{array}$ & RESOLUTION \\
\hline $\begin{array}{l}\text { 3.1.5/UP19: Update of } \\
\text { container location as } \\
\text { containers are removed } \\
\text { from storage and } \\
\text { transferred to the } \\
\text { shipping dock }\end{array}$ & $\begin{array}{l}\text { Appendix F specifies a location code } \\
\text { of SHIPDCK }\end{array}$ & code is named SHPDCK & & \\
\hline $\begin{array}{l}\text { 3.1.6/UP2: Process } \\
\text { List }\end{array}$ & $\begin{array}{l}\text { Appendix F specifies user is allowed } \\
\text { to Reorder and Commit data to } \\
\text { create PROCLIST table records }\end{array}$ & $\begin{array}{l}\text { system navigation makes no } \\
\text { reference to creation of records }\end{array}$ & $\begin{array}{l}\text { since preceding screens and } \\
\text { processing are obviously intended } \\
\text { to create records, system } \\
\text { navigation text should be updated }\end{array}$ & $\begin{array}{l}\text { Comments provided after } \\
\text { V\&V Review; need to } \\
\text { update SDD para 5.2.10.3 }\end{array}$ \\
\hline $\begin{array}{l}\text { 3.1.6/UP5: AS/RS } \\
\text { Retrieval and Storage } \\
\text { Via Transfer Car }\end{array}$ & $\begin{array}{l}\text { Appendix F specifies screen } \\
\text { selection "from menu" }\end{array}$ & $\begin{array}{l}\text { does not mention which menu, } \\
\text { but context implies Pick List } \\
\text { menu }\end{array}$ & $\begin{array}{l}\text { should specify menu hierarchy } \\
\text { selection for clarity }\end{array}$ & \multirow{2}{*}{$\begin{array}{l}\text { Comments provided after } \\
\text { review of V\&V } \\
\text { discrepancies: Appendix F } \\
\text { should be updated } \\
\text { Action Completed and } \\
\text { Discrepancy Item Closed } \\
\text { as of } 3 / 6 / 96\end{array}$} \\
\hline $\begin{array}{l}\text { 3.1.6/UP9: TRUPACT } \\
\text { Assembly List } \\
\text { Generation } \\
\text { 3.1.6/UP10: Save Data } \\
\text { to File }\end{array}$ & $\begin{array}{l}\text { specification not flagged for later } \\
\text { phases }\end{array}$ & $\begin{array}{l}\text { no mention of process being } \\
\text { Phase } 2 \text { or } 3\end{array}$ & $\begin{array}{l}\text { convention has been for all phase } \\
2 \text { and } 3 \text { development work to be } \\
\text { clearly marked as such - this } \\
\text { should be flagged accordingly }\end{array}$ & \\
\hline
\end{tabular}




\begin{tabular}{|c|c|c|c|c|}
\hline $\begin{array}{l}\text { DESIGN FEATURE } \\
\text { A }\end{array}$ & DESIGN FEATURE B & DISCREPANCY & $\begin{array}{l}\text { RATIONALE FOR } \\
\text { CATEGORY }\end{array}$ & RESOLUTION \\
\hline $\begin{array}{l}\text { 3.1.6/UP10: Save Data } \\
\text { to File }\end{array}$ & $\begin{array}{l}\text { no specification for activity in } \\
\text { system navigation }\end{array}$ & $\begin{array}{l}\text { save data to file is obvious intent } \\
\text { of preceding processing }\end{array}$ & $\begin{array}{l}\text { system navigation should be } \\
\text { updated to specify need for file } \\
\text { updates at end of work }\end{array}$ & $\begin{array}{l}\text { Comments provided after } \\
\text { V\&V Review: need to } \\
\text { update SDD Para } 5.2 .10 .6 \\
\text { - Phase } 3 \text { activity }\end{array}$ \\
\hline \multirow[t]{2}{*}{$\begin{array}{l}\text { 3.1.7/UP1: Radiologic } \\
\text { Inventory }\end{array}$} & $\begin{array}{l}\text { system navigation refers to selection } \\
\text { of Radiologic Inventory Summary } \\
\text { from Facility Metrics and } \\
\text { Inventories Screen }\end{array}$ & $\begin{array}{l}\text { no specification anywhere for a } \\
\text { Facility Metrics and Inventories } \\
\text { Screen }\end{array}$ & $\begin{array}{l}\text { system navigation should be } \\
\text { updated to reflect latest version of } \\
\text { screen hierarchy }\end{array}$ & $\begin{array}{l}\text { Comments provided after } \\
\text { V\&V review: current } \\
\text { menu selection is "Rad } \\
\text { Inv" - needs to be } \\
\text { reviewed form sufficiency } \\
\text { (see Appendix A hierarchy) } \\
\text { - Phase } 2 \text { activity }\end{array}$ \\
\hline & $\begin{array}{l}\text { Appendix } F \text { specifies that a screen } \\
\text { print be generated }\end{array}$ & no mention in system navigation & $\begin{array}{l}\text { system navigation should be } \\
\text { updated to include all processing }\end{array}$ & $\begin{array}{l}\text { Comments provided after } \\
\text { review of } Y \& V \\
\text { discrepancies: screen } \\
\text { navigation should be } \\
\text { updated Action Completed } \\
\text { and Discrepancy Item } \\
\text { Closed as of } 3 / 6 / 96\end{array}$ \\
\hline
\end{tabular}




\begin{tabular}{|c|c|c|c|c|}
\hline $\begin{array}{l}\text { DESIGN FEATURE } \\
\text { A }\end{array}$ & DESIGN FEATURE B & DISCREPANCY & $\begin{array}{l}\text { RATIONALE FOR } \\
\text { CATEGORY }\end{array}$ & RESOLUTION \\
\hline $\begin{array}{l}\text { 3.1.7/UP2: Container } \\
\text { Locations and } \\
\text { Relationships }\end{array}$ & $\begin{array}{l}\text { system navigation refers to selection } \\
\text { of Container Locations and } \\
\text { Relationships from Facility Metrics } \\
\text { and Inventories Screen }\end{array}$ & $\begin{array}{l}\text { no specification anywhere for a } \\
\text { Facility Metrics and Inventories } \\
\text { Screen }\end{array}$ & $\begin{array}{l}\text { system navigation should be } \\
\text { updated to reflect latest version of } \\
\text { screen hierarchy }\end{array}$ & $\begin{array}{l}\text { Comments provided after } \\
\text { V\&V Review: in Rev } 2 \text { of } \\
\text { SDD note, Sect } 5.2 .11 .2 \text {, } \\
\text { Appendix A fig A-86, } \\
\text { Appendix F } 3.1 .7 / \mathrm{UP} 2 \\
\text { Action Completed and } \\
\text { Discrepancy Item Closed } \\
\text { as of } 5 / 17 / 96\end{array}$ \\
\hline $\begin{array}{l}\text { 3.1.8/UP15: Drum at } \\
\text { TRU Glovebox Entry } \\
\text { Port } \\
\text { 3.1.8/UP20: Transfer } \\
\text { Drum at TRU RWM } \\
\text { Glovebox Entry Port } \\
\text { 3.1.8/UP24: Drum at } \\
\text { the S\&R Discharge } \\
\text { Conveyor } \\
\text { 3.1.8/UP42: TRU } \\
\text { Glovebox or TRU } \\
\text { RWM Glovebox Fissile } \\
\text { Material Level to PCS }\end{array}$ & $\begin{array}{l}\text { specifies use of } \\
\text { RADMAT_RAD_TOTAL }\end{array}$ & $\begin{array}{l}\text { field name is } \\
\text { RADMAT_RAD_TOT }\end{array}$ & typo: need to correct Appendix F & $\begin{array}{l}\text { To be resolved with } \\
\text { publication of new "as- } \\
\text { built" SDD revision. } \\
\text { Discrepancy Item Closed }\end{array}$ \\
\hline
\end{tabular}




\begin{tabular}{|c|c|c|c|c|}
\hline $\begin{array}{l}\text { DESIGN FEATURE } \\
\mathbf{A}\end{array}$ & DESIGN FEATURE B & DISCREPANCY & $\begin{array}{l}\text { RATIONALE FOR } \\
\text { CATEGORY }\end{array}$ & RESOLUTION \\
\hline $\begin{array}{l}\text { 3.1.8/UP50: Sample } \\
\text { and Purge Port } \\
\text { relationship from PCS }\end{array}$ & specifies use of SAM_LOCATION & field name is SAM_LOCN_ID & & \\
\hline $\begin{array}{l}\text { 3.1.8./UP58: } \\
\text { Treatment Container } \\
\text { and Item Container } \\
\text { relationship from PCS }\end{array}$ & specifies use of CONREL_REL_CD & field name is CONR_REL_CD & & . \\
\hline \multirow[t]{3}{*}{$\begin{array}{l}\text { 3.1.8/UP98: Box } \\
\text { Database to BWAS }\end{array}$} & message has fields $5,6,7$ & $\begin{array}{l}\text { same fields in pseudo-code are } \\
\text { referred to as } 1,2,3\end{array}$ & & \\
\hline & message has fields $4,5,6$ & $\begin{array}{l}\text { same fields in pseudo-code are } \\
\text { referred to as } 1,2,3\end{array}$ & & \\
\hline & specifies use of PISO_PROF_NUM & field name is PISO_PROF_ID & \multirow[t]{5}{*}{ typo: need to correct Appendix F } & \\
\hline \multirow[t]{4}{*}{$\begin{array}{l}\text { 3.1.8/UP99: Assay } \\
\text { Results from BWAS }\end{array}$} & $\begin{array}{l}\text { specifies use of } \\
\text { NDA_TMU_ALPHA_CI }\end{array}$ & $\begin{array}{l}\text { field name is } \\
\text { NDA_TOT_ALPHA_CI_TMU }\end{array}$ & & \multirow{4}{*}{ trat } \\
\hline & specifies use of NDA_TMU_PU_CI & $\begin{array}{l}\text { field name is } \\
\text { NDA_TOT_PE_CI_TMU }\end{array}$ & & \\
\hline & $\begin{array}{l}\text { specifies use of } \\
\text { NDA_TMU_PU_FGE }\end{array}$ & $\begin{array}{l}\text { field name is } \\
\text { NDA_TOT_PU_FGE_TMU }\end{array}$ & & \\
\hline & specifies use of NDA_TOT_PU_CI & field name is NDA_TOT_PE_CI & & \\
\hline
\end{tabular}




\begin{tabular}{|c|c|c|c|c|}
\hline $\begin{array}{l}\text { DESIGN FEATURE } \\
\text { A }\end{array}$ & DESIGN FEATURE B & DISCREPANCY & $\begin{array}{l}\text { RATIONALE FOR } \\
\text { CATEGORY }\end{array}$ & RESOLUTION \\
\hline $\begin{array}{l}\text { 3.1.9/UP1: Update of } \\
\text { container NDA data } \\
\text { for processed waste } \\
\text { drums } \\
\text { 3.1.9/UP8: Compacted } \\
\text { Drum data review } \\
\text { 3.1.9/UP11: Review of } \\
\text { NDA Result data for } \\
\text { containers which don't } \\
\text { go to processing in } \\
\text { WRAP 1 }\end{array}$ & $\begin{array}{l}\text { Appendix A shows display of Total } \\
\text { PE FGE }\end{array}$ & data element named PU FGE & apparent typo in screen print & $\begin{array}{l}\text { Comments provided after } \\
\text { review of V\&V } \\
\text { discrepancies: screen } \\
\text { should be updated } \\
\text { Action Completed and } \\
\text { Discrepancy Item Closed } \\
\text { as of } 5 / 17 / 96\end{array}$ \\
\hline $\begin{array}{l}\text { 3.1.4/UP3: User } \\
\text { selection of the } \\
\text { appropriate product } \\
\text { drum assay to be } \\
\text { recorded as the drum } \\
\text { certification assay }\end{array}$ & Appendix F cites NDA_ISO_NAME & $\begin{array}{l}\text { Appendix C has } \\
\text { NDAISO_NAME }\end{array}$ & typo: need to correct Appendix F & $\begin{array}{l}\text { To be resolved with } \\
\text { publication of new "as- } \\
\text { built" SDD revision. } \\
\text { Discrepancy ltem Closed }\end{array}$ \\
\hline
\end{tabular}




\begin{tabular}{|c|c|c|c|c|}
\hline $\begin{array}{c}\text { DESIGN FEATURE } \\
\text { A }\end{array}$ & DESIGN FEATURE B & DISCREPANCY & $\begin{array}{l}\text { RATIONALE FOR } \\
\text { CATEGORY }\end{array}$ & RESOLUTION \\
\hline $\begin{array}{l}\text { 3.1.9/UP8: Compacted } \\
\text { Drum data review }\end{array}$ & $\begin{array}{l}\text { system navigation refers to selection } \\
\text { of Puck Data button }\end{array}$ & $\begin{array}{l}\text { Appendix F specifies a } \\
\text { Compacted Drum Data button }\end{array}$ & $\begin{array}{l}\text { need to change one Appendix to } \\
\text { reflect actual button name }\end{array}$ & $\begin{array}{l}\text { Comments provided after } \\
\text { review of V\&V } \\
\text { discrepancies: screen } \\
\text { navigation should be } \\
\text { updated Action Completed } \\
\text { and Discrepancy Item } \\
\text { Closed as of } 3 / 6 / 96 \\
\end{array}$ \\
\hline 3.1.9/UP4s and UP5s & same unit process numbers used & more than one UP 4 and UP 5 & $\begin{array}{l}\text { need to change unit process } \\
\text { numbering to be unique for each } \\
\text { UP in a module }\end{array}$ & \multirow{3}{*}{$\begin{array}{l}\text { Comments provided after } \\
\text { review of V\&V } \\
\text { discrepancies: Appendix F } \\
\text { should be. updated } \\
\text { Action Completed and } \\
\text { Discrepancy Item Closed } \\
\text { as of } 3 / 6 / 96\end{array}$} \\
\hline $\begin{array}{l}\text { 3.1.9/UP5-7(?): User } \\
\text { review and } \\
\text { modification of drum } \\
\text { ISOQTY certification } \\
\text { records }\end{array}$ & Appendix $F$ specifies $R A D$ data store & $\begin{array}{l}\text { no RAD table in Appendix C - } \\
\text { given context of UP and data } \\
\text { elements used, obvious reference } \\
\text { to ISOQTY }\end{array}$ & \multirow[t]{2}{*}{$\begin{array}{l}\text { need to correct Appendix F table } \\
\text { call }\end{array}$} & \\
\hline $\begin{array}{l}\text { 3.1.9/UP21: User } \\
\text { denotes assay data } \\
\text { review is complete and } \\
\text { updates the WRAP } \\
\text { status code }\end{array}$ & $\begin{array}{l}\text { Appendix } F \text { specifies CONEXT data } \\
\text { store }\end{array}$ & $\begin{array}{l}\text { no CONEXT table in Appendix } \\
\mathrm{C} \text { - given context of UP and } \\
\text { data elements used, obvious } \\
\text { reference to WASTEXT }\end{array}$ & & \\
\hline
\end{tabular}




\begin{tabular}{|c|c|c|c|c|}
\hline $\begin{array}{l}\text { DESIGN FEATURE } \\
\text { A }\end{array}$ & DESIGN FEATURE B & DISCREPANCY & $\begin{array}{l}\text { RATIONALE FOR } \\
\text { CATEGORY }\end{array}$ & RESOLUTION \\
\hline $\begin{array}{l}\text { 3.1.9/UP24-25: Update } \\
\text { of container } \\
\text { relationships prior to } \\
\text { data review }\end{array}$ & $\begin{array}{l}\text { Appendix F lists attributes starting } \\
\text { with "CONREL" in data element } \\
\text { name }\end{array}$ & $\begin{array}{l}\text { no such data elements in } \\
\text { Appendix C - given context and } \\
\text { data store involved, obvious } \\
\text { reference to data elements } \\
\text { named with "CONR" }\end{array}$ & $\begin{array}{l}\text { need to correct Appendix F data } \\
\text { element names }\end{array}$ & \\
\hline $\begin{array}{l}\text { System } \\
\text { Administration: } \\
\text { Screen } 0451\end{array}$ & $\begin{array}{l}\text { system navigation specifies a screen } \\
\text { to maintain the Container Location } \\
\text { Table }\end{array}$ & $\begin{array}{l}\text { no screen print for maintenance } \\
\text { of this table }\end{array}$ & $\begin{array}{l}\text { table is in a regular state of } \\
\text { update during processing - may } \\
\text { not need a special screen - system } \\
\text { navigation should be updated }\end{array}$ & $\begin{array}{l}\text { Comments provided after } \\
\text { V\&V Review: cited action } \\
\text { needs to be taken } \\
\text { Action Completed and } \\
\text { Discrepancy Item Closed } \\
\text { as of } 5 / 17 / 96\end{array}$ \\
\hline $\begin{array}{l}\text { System } \\
\text { Administration: } \\
\text { Screen } 0453\end{array}$ & $\begin{array}{l}\text { system navigation refers to } \\
\text { Treatment Procedure Table screen } \\
\text { DMSS0453 }\end{array}$ & $\begin{array}{l}\text { Appendix A labels this screen } \\
0466\end{array}$ & $\begin{array}{l}\text { need to update system navigation } \\
\text { to correct screen number }\end{array}$ & $\begin{array}{l}\text { Comments provided after } \\
\text { review of V\&V } \\
\text { discrepancies: screen } \\
\text { navigation should be } \\
\text { updated Action Completed } \\
\text { and Discrepancy Item } \\
\text { Closed as of } 3 / 6 / 96\end{array}$ \\
\hline
\end{tabular}




\begin{tabular}{|c|c|c|c|c|}
\hline $\begin{array}{l}\text { DESIGN FEATURE } \\
\text { A }\end{array}$ & DESIGN FEATURE B & DISCREPANCY & $\begin{array}{l}\text { RATIONALE FOR } \\
\text { CATEGORY }\end{array}$ & RESOLUTION \\
\hline $\begin{array}{l}\text { System } \\
\text { Administration: } \\
\text { Screen } 0456\end{array}$ & $\begin{array}{l}\text { system navigation refers to } \\
\text { Shipment Picklist Description Table } \\
\text { screen DMSS0 } 456\end{array}$ & $\begin{array}{l}\text { Appendix A labels this screen } \\
\text { Shipping Pick List Type }\end{array}$ & $\begin{array}{l}\text { need to update system navigation } \\
\text { to correct screen name }\end{array}$ & $\begin{array}{l}\text { Comments provided after } \\
\text { review of V\&V } \\
\text { discrepancies: screen } \\
\text { navigation should be } \\
\text { updated Action Completed } \\
\text { and Discrepancy Item } \\
\text { Closed as of } 3 / 6 / 96\end{array}$ \\
\hline $\begin{array}{l}\text { System } \\
\text { Administration: } \\
\text { Screen } 0461\end{array}$ & $\begin{array}{l}\text { screen is for maintenance of the } \\
\text { WRAP Miscellaneous Table }\end{array}$ & $\begin{array}{l}\text { Appendix A screen print uses } \\
\text { sample data which is not in the } \\
\text { domain of this table }\end{array}$ & $\begin{array}{l}\text { should use more representative } \\
\text { table examples to preclude } \\
\text { confusion for reviewers }\end{array}$ & $\begin{array}{l}\text { Comments provided after } \\
\text { V\&V Review: cited action } \\
\text { needs to be taken } \\
\text { Action Completed and } \\
\text { Discrepancy Item Closed } \\
\text { as of } 5 / 17 / 96\end{array}$ \\
\hline $\begin{array}{l}\text { System } \\
\text { Administration: } \\
\text { Screen } 0706\end{array}$ & $\begin{array}{l}\text { system navigation refers to User } \\
\text { Role Table screen DMSS00706 }\end{array}$ & $\begin{array}{l}\text { Appendix A labels this screen } \\
0708\end{array}$ & $\begin{array}{l}\text { need to update system navigation } \\
\text { to correct screen number }\end{array}$ & $\begin{array}{l}\text { Comments provided after } \\
\text { review of V\&V } \\
\text { discrepancies: screen } \\
\text { navigation should be } \\
\text { updated Action Completed } \\
\text { and Discrepancy Item } \\
\text { Closed as of } 3 / 6 / 96\end{array}$ \\
\hline
\end{tabular}




\begin{tabular}{|c|c|c|c|c|}
\hline $\begin{array}{l}\text { DESIGN FEATURE } \\
\text { A }\end{array}$ & DESIGN FEATURE B & DISCREPANCY & $\begin{array}{l}\text { RATTONALE FOR } \\
\text { CATEGORY }\end{array}$ & RESOLUTION \\
\hline Table PKGDW & $\begin{array}{l}\text { Data Element/Table name listing has } \\
\text { PDW_PKG_DD }\end{array}$ & $\begin{array}{l}\text { Data Element/Table definition } \\
\text { listing has PDW_PGK_ID }\end{array}$ & $\begin{array}{l}\text { apparent typo in the definition } \\
\text { listing - all package IDs in the } \\
\text { system have been named } \\
\text { "PKG_ID" }\end{array}$ & $\begin{array}{l}\text { Comments provided after } \\
\text { review of V\&V } \\
\text { discrepancies: Appendix C } \\
\text { should be updated } \\
\text { Action Completed and } \\
\text { Discrepancy Item Closed } \\
\text { as of } 3 / 6 / 96\end{array}$ \\
\hline Table ACTCOM & ACT_OP_COMMENTS & \multirow{10}{*}{$\begin{array}{l}\text { Data Element in Oracle does not } \\
\text { exist in Dictionary }\end{array}$} & \multirow{10}{*}{$\begin{array}{l}\text { Need to update Appendix } \mathrm{C} \text { to } \\
\text { match "as built" or need to update } \\
\text { Oracle structure to match } \\
\text { approved design (i.e., SCRs) or } \\
\text { "tag-along" SWITS data element } \\
\text { not used by WRAP }\end{array}$} & \multirow{10}{*}{$\begin{array}{l}\text { To be resolved with } \\
\text { publication of new "as- } \\
\text { built" SDD revision. } \\
\text { Discrepancy Item Closed }\end{array}$} \\
\hline Table CONSIZE & CSZ_BILL_VOL & & & \\
\hline Table DOTSPEC & DOT_CNTYP_CD & & & \\
\hline Table FIELDANAL & FIELD_SAMPLE_ID & & & \\
\hline Table FTELDSCRN & SCRN_SAMPLE_ID & & & \\
\hline Table HAZCOMP & HCC_DISCARD & & & \\
\hline \multirow[t]{4}{*}{ Table HAZDETAIL } & HDET_SHIP_CD & & & \\
\hline & HDET_SI_COMPAT_GRP & & & \\
\hline & HDET_SI_NUM & & & \\
\hline & HDET_SI_WASTE_DESCR & & & \\
\hline
\end{tabular}




\begin{tabular}{|c|c|c|c|c|}
\hline $\begin{array}{c}\text { DESIGN FEATURE } \\
\text { A }\end{array}$ & DESIGN FEATURE B & DISCREPANCY & $\begin{array}{l}\text { RATIONALE FOR } \\
\text { CATEGORY }\end{array}$ & RESOLUTION \\
\hline \multirow{4}{*}{$\begin{array}{l}\text { Table } \\
\text { HAZDETAR_JN }\end{array}$} & HDET_SHIP_CD & & & \\
\hline & HDET_SI_COMPAT_GRP & & & \\
\hline & HDET_SI_NUM & & & \\
\hline & HDET_SI_WASTE_DESCR & & & \\
\hline \multirow[t]{3}{*}{ Table ISOTOPE } & ISO_A2_LIM & & & \\
\hline & ISO_LFMW_LIM & & & \\
\hline & ISO_LOV & & & \\
\hline \multirow[t]{5}{*}{ Table NDA } & NDA_PROF_FLAG & & & \\
\hline & NDA_TMU_ALPHA_CI & & & \\
\hline & NDA_TMU_PE_CI & & & \\
\hline & NDA_TMU_PU_FGE & & & \\
\hline & NDA_TMU_THERMAL_POWER & & & \\
\hline Table NDAISO & NDAISO_DT & & & \\
\hline Table NDE & NDE_PASSED_FLAG & & & \\
\hline
\end{tabular}




\begin{tabular}{|c|c|c|c|c|}
\hline $\begin{array}{c}\text { DESIGN FEATURE } \\
\text { A }\end{array}$ & DESIGN FEATURE B & DISCREPANCY & $\begin{array}{l}\text { RATIONALE FOR } \\
\text { CATEGORY }\end{array}$ & RESOLUTYON \\
\hline & NDE_VTAPE_STOR_LOCN & & & \\
\hline \multirow[t]{7}{*}{ Table PERSON } & PERS_ANALYST & & & \\
\hline & PERS_ENTRY & & & \\
\hline & PERS_FIRST & & & \\
\hline & PERS_OPS & & & \\
\hline & PERS_RECEIPT & & & \\
\hline & PERS_TECH & & & \\
\hline & PERS_VERIF & & & \\
\hline Table PHYSDESC & PDESC_LOV & & & \\
\hline Table PROFILE & PROF_PU239 & & & \\
\hline \multirow[t]{5}{*}{ Table RADDETAKL } & RDET_BEG_COORD_N & & & \\
\hline & RDET_BEG_COORD_W & & & \\
\hline & RDET_CMPCT_PCT & & & \\
\hline & RDET_CMPCT_PIN & & & \\
\hline & RDET_END_COORD_N & & & \\
\hline
\end{tabular}




\begin{tabular}{|c|c|c|c|c|}
\hline $\begin{array}{c}\text { DESIGN FEATURE } \\
\mathrm{A}\end{array}$ & DESIGN FEATURE B & DISCREPANCY & $\begin{array}{l}\text { RATIONALE FOR } \\
\text { CATEGORY }\end{array}$ & RESOLUTION \\
\hline & RDET_END_COORD_W & & & \\
\hline & RDET_PRORATED_CMPCT_WGT & & & \\
\hline & RDET_RELOC_DT & & & \\
\hline & RDET_SWSDR_NUM & & & \\
\hline \multirow{9}{*}{$\begin{array}{l}\text { Table } \\
\text { RADDETAL_JN }\end{array}$} & $\mathrm{RDET}_{-} \mathrm{BEG}_{-} \mathrm{COORD_{- } N} \mathrm{N}$ & & & \\
\hline & RDET_BEG_COORD_W & & & \\
\hline & RDET_CMPCT_PCT & & & \\
\hline & RDET_CMPCT_PIN & & & \\
\hline & RDET_END_COORD_N & & & \\
\hline & RDET_END_COORD_W & & & \\
\hline & RDET_PRORATED_CMPCT_WGT & & & · \\
\hline & RDET_RELOC_DT & & & \\
\hline & RDET_SWSDR_NUM & & & \\
\hline \multirow[t]{2}{*}{ Table SAMPLE } & SAM_DISP_BY & & & \\
\hline & SAM_DISP_DT & & & \\
\hline
\end{tabular}




\begin{tabular}{|c|c|c|c|c|}
\hline $\begin{array}{c}\text { DESIGN FEATURE } \\
\mathbf{A}\end{array}$ & DESIGN FEATURE B & DISCREPANCY & $\begin{array}{l}\text { RATIONALE FOR } \\
\text { CATEGORY } \\
\end{array}$ & RESOLUTION \\
\hline & SAM_DISP_METHOD & & & \\
\hline & SAM_FORM_ID & & & \\
\hline & SAM_LAB_ID & & & \\
\hline & SAM_OK_AT_LAB & & & \\
\hline & SAM_RAD_REPORT_DT & & & \\
\hline & SAM_RETURN_DT & & & \\
\hline & SAM_RETURN_TO_PKG & & & \\
\hline & SAM_TO_LAB_DT & & & \\
\hline & SAM_TO_RAD_LAB_DT & & & \\
\hline \multirow[t]{6}{*}{ Table SAMPLE_JN } & SAM_DISP_BY & & & \\
\hline & SAM_DISP_DT & & & \\
\hline & SAM_DISP_METHOD & & & \\
\hline & SAM_FORM_ID & & & \\
\hline & SAM_LAB_ID & & & \\
\hline & SAM_OK_AT_LAB & & & \\
\hline
\end{tabular}




\begin{tabular}{|c|c|c|c|c|}
\hline $\begin{array}{c}\text { DESIGN FEATURE } \\
\text { A }\end{array}$ & DESIGN FEATURE B & DISCREPANCY & $\begin{array}{c}\text { RATIONALE FOR } \\
\text { CATEGORY } \\
\end{array}$ & RESOLUTION \\
\hline & SAM_RAD_REPORT_DT & & & \\
\hline & SAM_RETURN_DT & & & \\
\hline & SAM_RETURN_TO_PKG & & & \\
\hline & SAM_TO_LAB_DT & & & \\
\hline & SAM_TO_RAD_LAB_DT & & & \\
\hline Table SAMREL & SAMREL_SAMPLE_ID & & & \\
\hline Table SAMREL_JN & SAMREL_SAMPLE_ID & & & \\
\hline \multirow[t]{5}{*}{ Table SHIPITEM } & SHPITM_CELLS & & & \\
\hline & SHPITM_CELL_TEXT_CD & & & \\
\hline & SHPTTM_COMMENT & & & \\
\hline & SHPITM_DISP_COST & & & \\
\hline & SHPITM_PACKING_GRP & & & \\
\hline \multirow[t]{3}{*}{ Table SHIPMENT } & SHPMNT_ARRIVAL_DT & & & \\
\hline & SHPMNT_COST_EST & & & \\
\hline & SHPMNT_INVOICE & & & \\
\hline
\end{tabular}




\begin{tabular}{|c|c|c|c|c|}
\hline $\begin{array}{l}\text { DESIGN FEATURE } \\
\text { A }\end{array}$ & DESIGN FEATURE B & DISCREPANCY & $\begin{array}{l}\text { RATIONALE FOR } \\
\text { CATEGORY }\end{array}$ & RESOLUTION \\
\hline & SHPMNT_PO_NUM & & & \\
\hline & SHPMNT_REQ_NUM & & & \\
\hline Table STORAGECAT & SCAT 616 & & & \\
\hline \multirow[t]{2}{*}{ Table TRUCON } & TRU_CON_CD & & & \\
\hline & TRU_CON_DESCR & & & \\
\hline \multirow[t]{2}{*}{ Table TSDFACX } & TFAC_CLASS & & & \\
\hline & TFAC_PHONE & & & \\
\hline \multirow[t]{8}{*}{ Table WASTE } & CON_ABS_TYPE & & & \\
\hline & CON_ADTL_COMMENT & & & \\
\hline & CON_ALERT_FLAG & & & \\
\hline & CON_ALERT_REASON_CD & & & \\
\hline & CON_BACKLOG_FLAG & & & \\
\hline & CON_CNTR_RECV_DT & & & \\
\hline & CON_CODE1 & & & \\
\hline & CON_CODE2 & & & \\
\hline
\end{tabular}




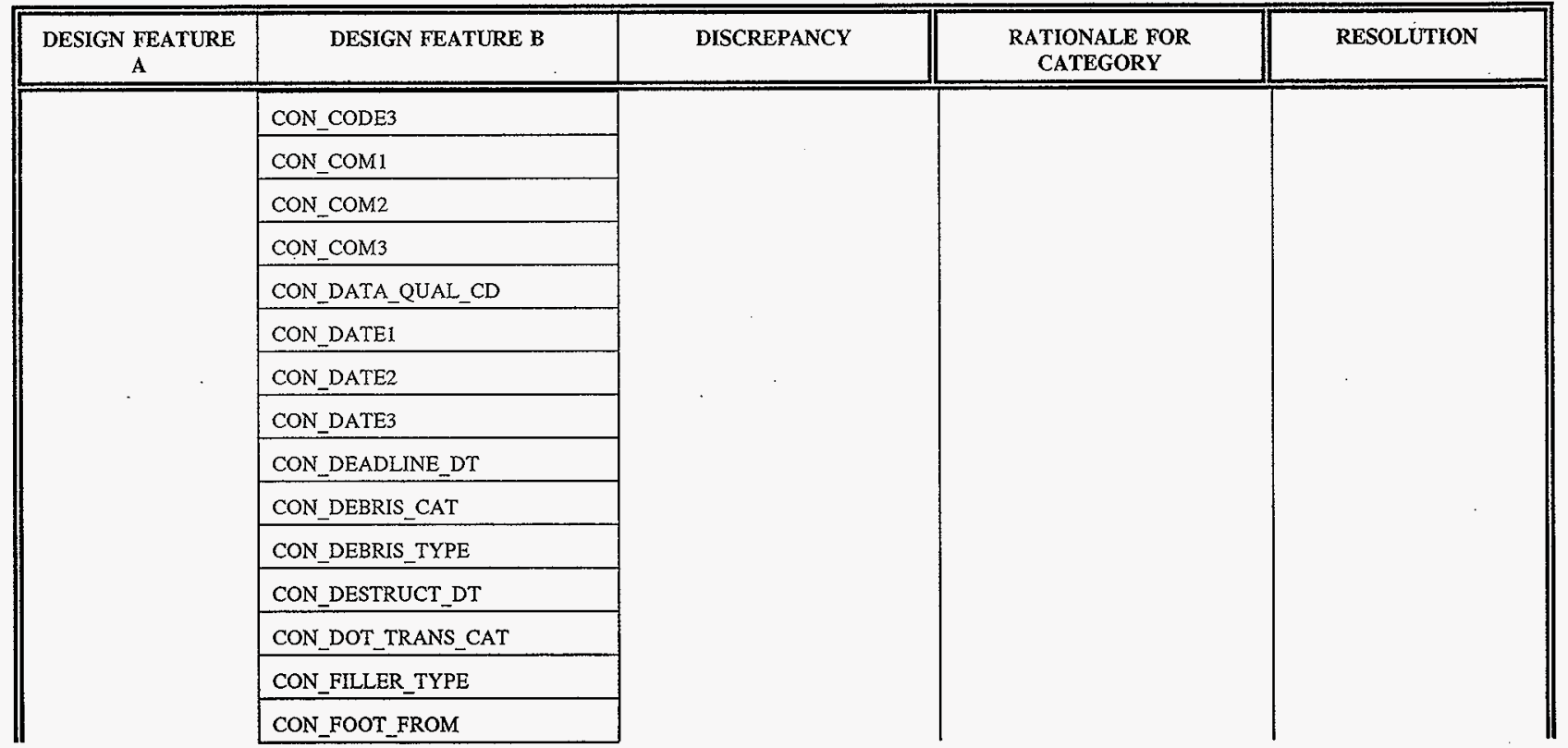




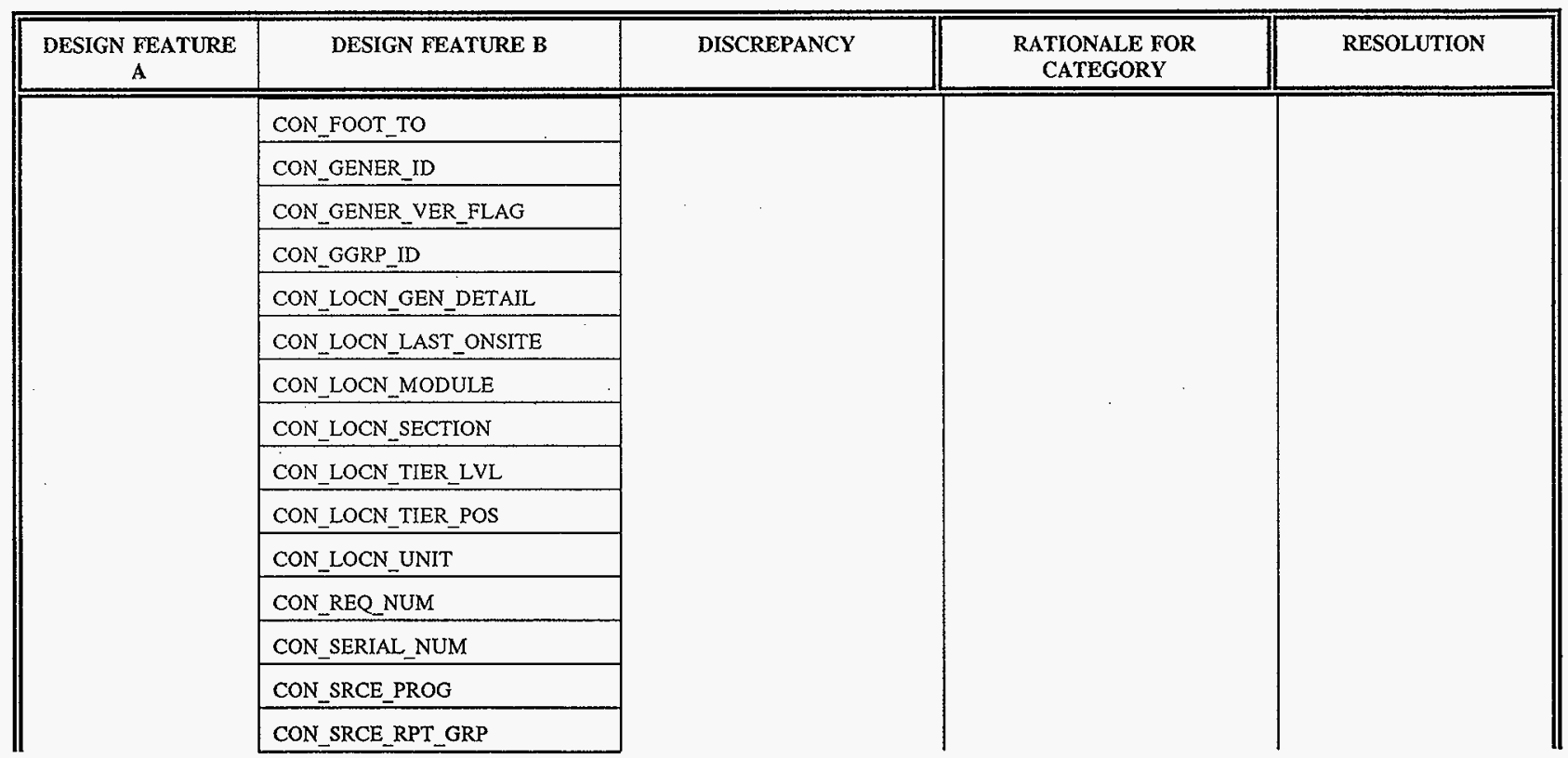




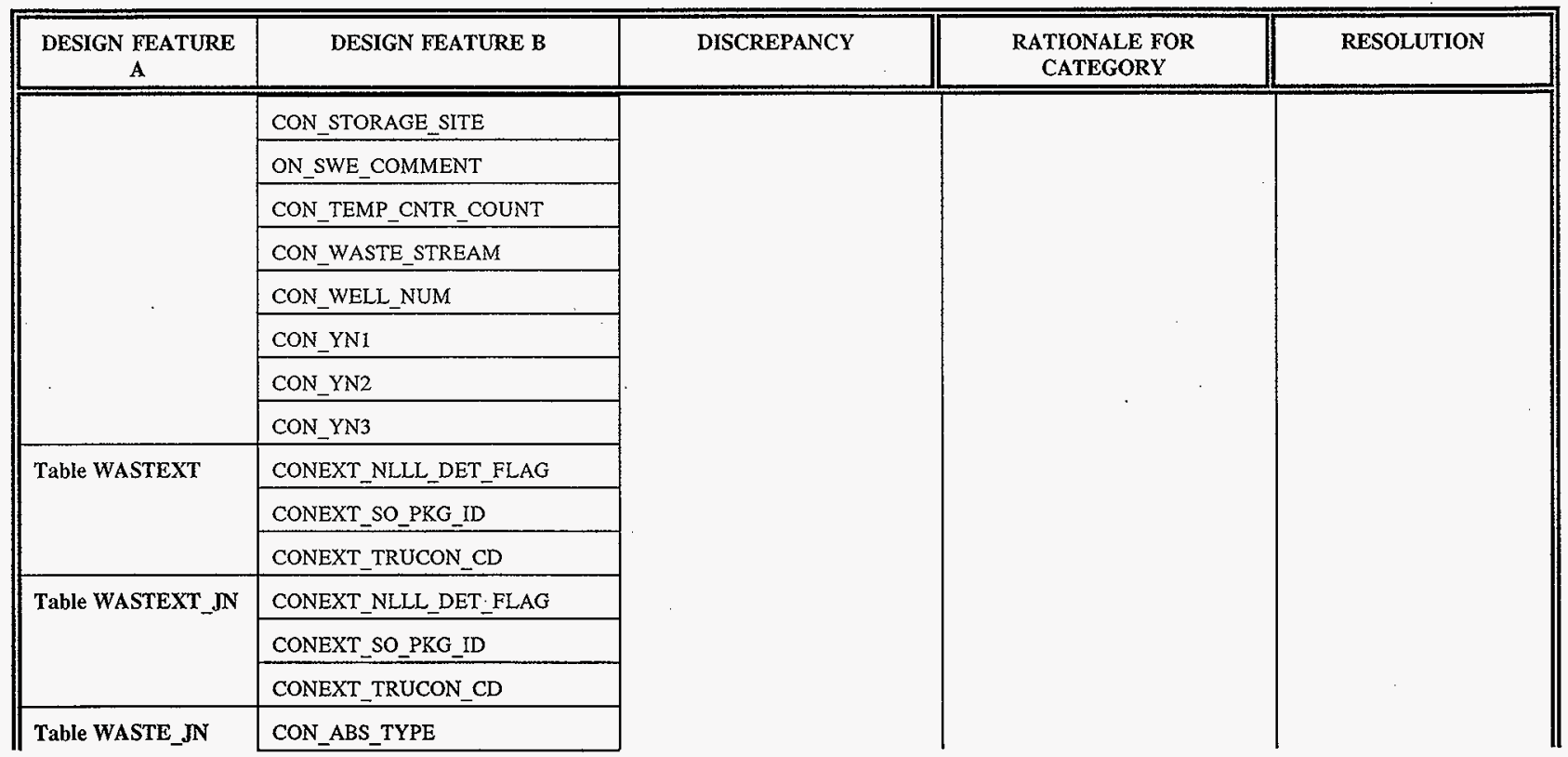




\begin{tabular}{|c|c|c|c|c|}
\hline $\begin{array}{c}\text { DESIGN FEATURE } \\
\text { A }\end{array}$ & DESIGN FEATURE B & DISCREPANCY & $\begin{array}{l}\text { RATYONALE FOR } \\
\text { CATEGORY }\end{array}$ & RESOLUTION \\
\hline & CON_ADTL_COMMENT & & \multirow{15}{*}{ 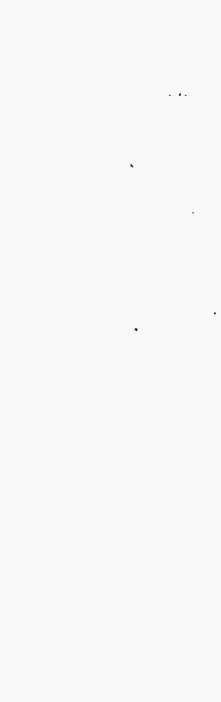 } & \\
\hline & CON_ALERT_FLAG & & & \\
\hline & CON_ALERT_REASON_CD & & & \\
\hline & CON_BACKLOG_FLAG & & & \\
\hline & CON_CNTR_RECV_DT & & & \\
\hline & CON_CODE1 & & & \\
\hline & CON_CODE2 & & & \\
\hline & CON_CODE3 & & & \\
\hline & CON_COM1 & & & \\
\hline & CON_COM2 & & & \\
\hline & CON_COM3 & & & \\
\hline & CON_DATA_QUAL_CD & & & \\
\hline & CON_DATE1 & & & \\
\hline & CON_DATE2 & & & \\
\hline & CON_DATE3 & & & \\
\hline
\end{tabular}




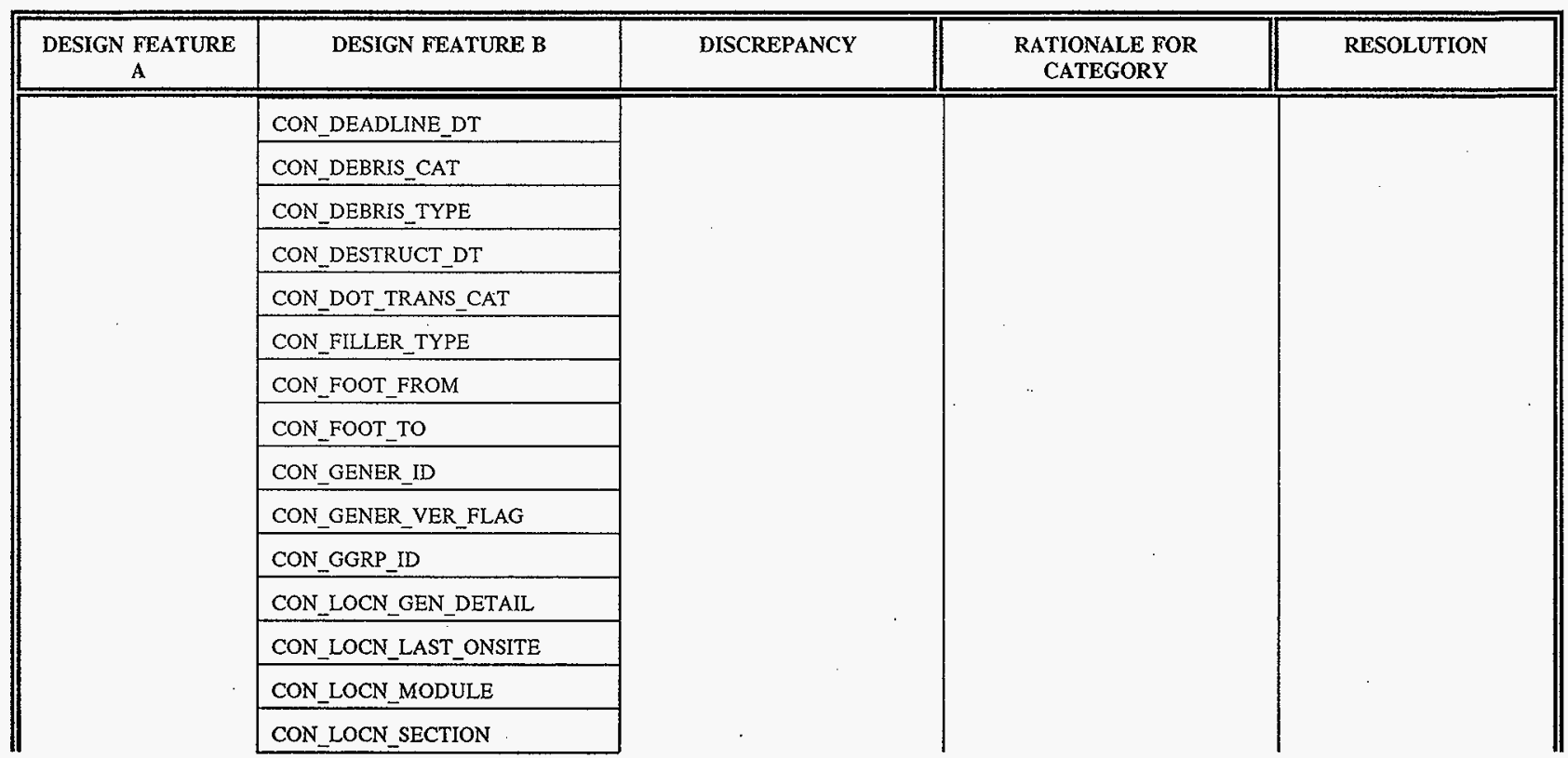


WRAP 1 DMS VALIDATION AND

VERIFICATION REPORT
HNF-1783

Revision 0

September 27, 1996

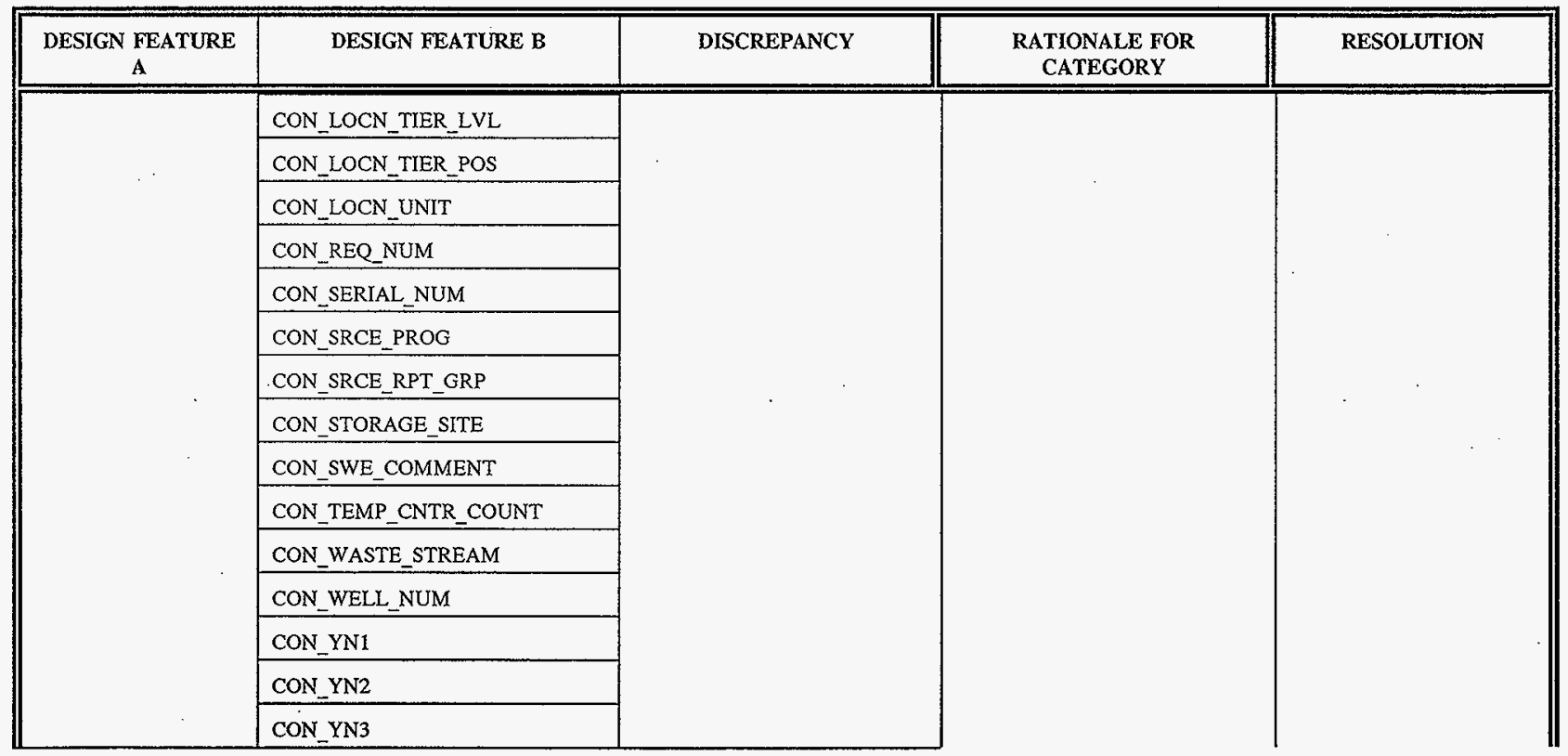




\begin{tabular}{|c|c|c|c|c|}
\hline $\begin{array}{l}\text { DESIGN FEATURE } \\
\text { A }\end{array}$ & DESIGN FEATURE B & DISCREPANCY & $\begin{array}{l}\text { RATIONALE FOR } \\
\text { CATEGORY }\end{array}$ & RESOLUTION \\
\hline $\begin{array}{l}\text { Table DOTSPEC } \\
\text { references CONTYPE }\end{array}$ & $\begin{array}{l}\text { DOT_CNTYP_CD references } \\
\text { CNTYP_CD }\end{array}$ & \multirow[t]{7}{*}{$\begin{array}{l}\text { Foreign Key not defined in Data } \\
\text { Dictionary }\end{array}$} & & \multirow{7}{*}{. } \\
\hline $\begin{array}{l}\text { Table FIELDANAL } \\
\text { references SAMPLE }\end{array}$ & FIELD_SAMPLE_ID references & & & \\
\hline $\begin{array}{l}\text { Table SAMPLE } \\
\text { references LAB }\end{array}$ & SAM_LAB_ID references $L A B \_I D$ & & & \\
\hline $\begin{array}{l}\text { Table SAMREL } \\
\text { references SAMPLE }\end{array}$ & $\begin{array}{l}\text { SAMREL_SAMPLE_ID references } \\
\text { SAMPLE_ID }\end{array}$ & & & \\
\hline $\begin{array}{l}\text { Table SAR references } \\
\text { LABANAL }\end{array}$ & $\begin{array}{l}\text { SAR_ANAL_CD references } \\
\text { LABANAL_ID }\end{array}$ & & & \\
\hline $\begin{array}{l}\text { Table SAR references } \\
\text { SAMPLE }\end{array}$ & $\begin{array}{l}\text { SAR_SAMPLE_ID references } \\
\text { SAMPLE_ID }\end{array}$ & & & \\
\hline $\begin{array}{l}\text { Table SECURITY } \\
\text { references USER }\end{array}$ & $\begin{array}{l}\text { SEC_USERID references } \\
\text { USR_USERID }\end{array}$ & & & \\
\hline
\end{tabular}




\begin{tabular}{|c|c|c|c|c|}
\hline $\begin{array}{l}\text { DESIGN FEATURE } \\
\text { A }\end{array}$ & DESIGN FEATURE B & DISCREPANCY & $\begin{array}{l}\text { RATIONALE FOR } \\
\text { CATEGORY }\end{array}$ & RESOLUTION \\
\hline \multirow[t]{2}{*}{ Main Menu } & no specification in screen hierarchy & N/A & $\begin{array}{l}\text { need to update Appendix A screen } \\
\text { hierarchy to reflect interplay with } \\
\text { Main Menu }\end{array}$ & $\begin{array}{l}\text { Comments provided after } \\
\text { review of V\&V } \\
\text { discrepancies: screen } \\
\text { hierarchy should be added } \\
\text { to Appendix A } \\
\text { Action Completed and } \\
\text { Discrepancy Item Closed } \\
\text { as of } 3 / 6 / 96\end{array}$ \\
\hline & $\begin{array}{l}\text { system navigation has no discussion } \\
\text { on selection of Bar Code Label from } \\
\text { Main Menu }\end{array}$ & $\begin{array}{l}\text { Appendix } F \text { and } A \text { show screen } \\
0102 \text { as being available from } \\
\text { Main Menu }\end{array}$ & $\begin{array}{l}\text { need to update system navigation } \\
\text { text }\end{array}$ & $\begin{array}{l}\text { Comments provided after } \\
\text { review of V\&V } \\
\text { discrepancies: screen } \\
\text { navigation should be } \\
\text { updated Action Completed } \\
\text { and Discrepancy Item } \\
\text { Closed as of } 3 / 6 / 96\end{array}$ \\
\hline
\end{tabular}




\subsection{DMS COMMUNICATIONS MODULE}

\subsubsection{Puirpose}

This analysis compares the discreet features and elements specified in the SDD Appendices and text. It then compares the DMSCOM source code to the SDD. The intent is to determine the consistency of the design across each part of the SDD specification to gauge the overall design integrity, and to determine the resultant accuracy of the code.

\subsubsection{Scope}

This analysis examined the source code for all Phase 1 development messages and compared it to the Appendix $\mathrm{F}$ specifications and the Appendix $\mathrm{C}$ data definitions.

A comparison of the Appendix F specifications with their use of data elements in Appendix $\mathrm{C}$ was conducted and is reported in Section 4.2.

\subsubsection{Description of Analysis Approach}

For this analysis one matrix was prepared.

Comments in the matrix are intended to point out discrepancies in the comparisons, or other insights which the analyst deemed necessary to bring to the system owner's attention.

Where comments pertain to discrepancies, these were categorized to reflect their potential severity or impact on the design.

\subsubsection{Analytic Overview}

\subsubsection{General Observations}

In addition to the comments and discrepancies noted in the matrices, the following general comments are noted: 
General Category 1 Discrepancy for DMSSIE DD: Possible memory 'over-run' condition

When the ora_pcsdms_clo is called, the memory for variable msg_is, used by DMSCOM to hold the message string, is 500 characters. Depending on the number of 'CHAD' and 'ABUN' sub-messages, a memory 'over-run' condition could occur. The message string could over write other program data and object code. Ten or more CHAD sub-messages with no ABUN sub-messages will cause an memory 'overrun' condition. Nine or more ABUN sub-messages with no CHAD sub-messages will cause an memory 'over-run' condition. In fact, if a total of ten sub-messages in any combination of either CHAD or ABUN will cause a memory 'over-run' condition. The SDD does not mention the maximum number of sub-messages.

When the dmssie_dd() function is called the memory allocated for holding XDR messages in the format is 2000 characters. The original message is an ASCII character string having numerics as ASCII characters. The XDR message format has numerics as binary, which is more space efficient than ASCII. The msg is variable ora_pcsdms_cl 0 should be larger than the message variable in dmssie_dd 0 .

Resolution: 01/30/96: Test Proc Review Meet: DD will be set to 5000 characters all others will be set to 2000

\subsubsection{Discrepancy Synopsis and Resolution Matrices}

The following matrix contains a synopsis of the discrepancies which are described in more detail in the analytic matrices found in the DMS project files. This synopsis groups the discrepancies by category. It then provides resolution actions which were decided during the course of the V\&V analysis. Those actions which are closed are also noted.

The resolution matrix will be considered a tracking mechanism to monitor all discrepancies until they are closed. Consequently, it will be periodically updated to reflect closed actions. If requirements are changed during the DMS development, these changes will be noted in the resolution matrix as pending actions and tracked as with any other actiions. 


\begin{tabular}{|c|c|c|c|c|}
\hline $\begin{array}{l}\text { APPENDIX F DESIGN } \\
\text { (PROCESS 3.1.8) }\end{array}$ & DESIGN CONTENT & DISCREPANCY & $\begin{array}{c}\text { RATIONALE FOR } \\
\text { CATEGORY }\end{array}$ & RESOLUTYON \\
\hline \multicolumn{5}{|c|}{ CATEGORY 1 DISCREPANCIES } \\
\hline UP1: Log all Messages & Throughout DSMCOM & Not all of the routines log messages & $\begin{array}{l}\text { Appropriate action may } \\
\text { not be taken }\end{array}$ & \multirow{2}{*}{$\begin{array}{l}\text { Message code validated } \\
\text { during testing. Revised } \\
\text { specifications to be published } \\
\text { as new baseline with "as- } \\
\text { built" SDD revision. } \\
\text { Discrepancy item closed }\end{array}$} \\
\hline $\begin{array}{l}\text { UP26: Background drum at } \\
\text { Background Drum storage } \\
\text { Conveyers } \\
\text { UP27: Drum stored in } \\
\text { NDE / NDA Carousel } \\
\text { UP31: Drum at the infeed } \\
\text { Conveyer Scale } \\
\text { UP37: Drum at Airlock } \\
\text { Conveyer Scale }\end{array}$ & $\begin{array}{l}\text { PCSDMS.PC: lines 1847, } \\
2038,2595,3176\end{array}$ & $\begin{array}{l}\text { DMSSIE DD message not correctly } \\
\text { formatted due to incorrect test of } \\
\text { counter1 - the source code tests local } \\
\text { variable counter 1 for true or false. If } \\
\text { counter1 is true (non-zero), an empty } \\
\text { ABUN message is formatted and } \\
\text { appended to the message string to be } \\
\text { sent. If counter1 is false (zero), the } \\
\text { "else" portion of the "if" statement is } \\
\text { executed to format ABUN message. } \\
\text { However, no message is formatted } \\
\text { because counter } 1 \text { is zero, and there is no } \\
\text { data to format }\end{array}$ & $\begin{array}{l}\text { SIE not receiving drum } \\
\text { database; thus not } \\
\text { performing required } \\
\text { function }\end{array}$ & \\
\hline
\end{tabular}




\begin{tabular}{|c|c|c|c|c|}
\hline $\begin{array}{l}\text { APPENDIX F DESIGN } \\
\text { (PROCESS 3.1.8) }\end{array}$ & DESIGN CONTENT & DISCREPANCY & $\begin{array}{l}\text { RATIONALE FOR } \\
\text { CATEGORY }\end{array}$ & RESOLUTION \\
\hline & $\begin{array}{l}\text { PCMSDMS.PC: lines 1861, } \\
2052,2068,3189\end{array}$ & $\begin{array}{l}\text { DMSSIE DD message not correctly } \\
\text { formatted due to incorrect test of } \\
\text { counter } 2 \text { - the source code tests local } \\
\text { variable counter } 2 \text { for true or false. If } \\
\text { counter } 2 \text { is true (non-zero), an empty } \\
\text { isotope message is formatted and } \\
\text { appended to the message string to be } \\
\text { sent. If counter } 2 \text { is false (zero), the } \\
\text { "else" portion of the "if" statement is } \\
\text { executed to format isotope message. } \\
\text { However, no message is formatted } \\
\text { because counter } 2 \text { is zero, and there is no } \\
\text { data to format }\end{array}$ & & \\
\hline $\begin{array}{l}\text { UP61: Request for BWAS } \\
\text { status from PCS }\end{array}$ & \multirow[t]{2}{*}{ PCSDMS.PC: line 5446} & $\begin{array}{l}\text { Source code not in sine with SDD. } \\
\text { Message not sent. The function } \\
\text { dmsrba_rbwa() does not exist. The line } \\
\text { of code that calls this function is } \\
\text { commented out }\end{array}$ & \multirow[t]{2}{*}{$\begin{array}{l}\text { DMS does not receive } \\
\text { status of BWAS }\end{array}$} & \\
\hline $\begin{array}{l}\text { UP64: BWAS Status to } \\
\text { PCS }\end{array}$ & & $\begin{array}{l}\text { Does not seem to be implemented. } \\
\text { There is a comment stating "the sending } \\
\text { of the DMSPCS SBWA message was } \\
\text { sent in function "bwadms_sbwa0" (not } \\
\text { yet written as of 7/30/95." The function } \\
\text { "bwadms sbwa0" does not exist. } \\
\text { Source code is not in sinc with SDD }\end{array}$ & & \\
\hline
\end{tabular}




\begin{tabular}{|c|c|c|c|c|}
\hline $\begin{array}{l}\text { APPENDIX F DESIGN } \\
\text { (PROCESS 3.1.8) }\end{array}$ & DESIGN CONTENT & DISCREPANCY & $\begin{array}{l}\text { RATIONALE FOR } \\
\text { CATEGORY }\end{array}$ & RESOLUTION \\
\hline $\begin{array}{l}\text { UP:67: BWAS Assay } \\
\text { Aborted from BWAS }\end{array}$ & & $\begin{array}{l}\text { Does not seem to be implemented. } \\
\text { Source code is not in sync with SDD }\end{array}$ & $\begin{array}{l}\text { DMS does not know and } \\
\text { record BWAS Assay } \\
\text { being aborted }\end{array}$ & \\
\hline $\begin{array}{l}\text { UP87: Processing Pick List } \\
\text { Items to PCS }\end{array}$ & MSGPCSDM.C & $\begin{array}{l}\text { According to the SDD, Appendix F, } \\
\text { DMSCOM selects the data from the } \\
\text { database. Nowhere has this been found. } \\
\text { The routine functions as if PCS sends to } \\
\text { DMS the items to be processed. source } \\
\text { code is not in sync with SDD }\end{array}$ & $\begin{array}{l}\text { The proper message pick } \\
\text { list message is not sent }\end{array}$ & \\
\hline $\begin{array}{l}\text { UP96: Non-listed, long- } \\
\text { lived nuclides detected } \\
\text { from SIE }\end{array}$ & PCSDMS.PC & $\begin{array}{l}\text { The routine does not update } \\
\text { MSGLOG_INIT_FLAG to 'DF' or } \\
\text { CONTEXT_NLLE_DETECTED to } \\
\text { system date. It does, however, set } \\
\text { conext_nll1_dat_flag = 'Y'. Source } \\
\text { code not in sync with SDD }\end{array}$ & $\begin{array}{l}\text { Database is not properly } \\
\text { updated }\end{array}$ & $\begin{array}{l}\text { 1/30/96: Test Proc Review } \\
\text { Meet: should refer to } \\
\text { MSGLOG_INIT_FLAG }\end{array}$ \\
\hline
\end{tabular}




\begin{tabular}{|c|c|c|c|c|}
\hline $\begin{array}{l}\text { APPENDIX F DESIGN } \\
\text { (PROCESS 3.1.8) }\end{array}$ & DESIGN CONTENT & DISCREPANCY & $\begin{array}{l}\text { RATIONALE FOR } \\
\text { CATEGORY }\end{array}$ & RESOLUTION \\
\hline \multicolumn{5}{|c|}{ CATEGORY 2 DISCREPANCIES } \\
\hline UP1: Log All Messages & PCSDMS.PC & $\begin{array}{l}\text { Binary output of the message only } \\
\text { occurs if pcs_log_flag is true }\end{array}$ & $\begin{array}{l}\text { System may not be } \\
\text { logging all messages }\end{array}$ & \multirow{5}{*}{$\begin{array}{l}\text { Message code validated } \\
\text { during testing. Revised } \\
\text { specifications to be publisher } \\
\text { as new baseline with "as- } \\
\text { built" SDD revision. } \\
\text { Discrepancy item closed. }\end{array}$} \\
\hline $\begin{array}{l}\text { UP12: BOX at box NDA } \\
\text { Vault }\end{array}$ & PCSDMS.PC: lines 5418-5422 & $\begin{array}{l}\text { Phase } 2 \text { requirements in code: Cited } \\
\text { lines update DMS for conloc_locn_id = } \\
\text { BOXNDA }\end{array}$ & $\begin{array}{l}\text { Database is not properly } \\
\text { updated }\end{array}$ & \\
\hline $\begin{array}{l}\text { UP24: Drum at the } S \& R \\
\text { Drum Discharge Conveyer }\end{array}$ & $\begin{array}{l}\text { PCSDMS.PC: lines } 1583-1586 \\
\text { and } 1588-1590\end{array}$ & $\begin{array}{l}\text { The source code contains both Phase } 1 \\
\text { and Phase } 3 \text { requirements. The source } \\
\text { code lines (1607-1637) for the Phase } 3 \\
\text { requirements are NOT commented out. } \\
\text { The source code (lines 1639-1656) for } \\
\text { Phase } 3 \text { ARE commented out. }\end{array}$ & $\begin{array}{l}\text { Additional functionality is } \\
\text { performed. Messages are } \\
\text { sent for which the rest of } \\
\text { the system is not ready to } \\
\text { handle }\end{array}$ & \\
\hline \multirow[t]{2}{*}{$\begin{array}{l}\text { UP26: Background drum at } \\
\text { Background Drum Storage } \\
\text { Conveyers. }\end{array}$} & PCSDMS.PC: lines 1693-1725 & $\begin{array}{l}\text { The SDD Appendix F states the third } \\
\text { field for characterization is ' } 0 \text { '. The } \\
\text { source code has ' } 1 \text { '. The fourth field } \\
\text { should be NULL. The source code has } \\
\text { 'T' }\end{array}$ & $\begin{array}{l}\text { Message is not properly } \\
\text { sent }\end{array}$ & \\
\hline & $\begin{array}{l}\text { PCSDMS.PCL: lines 1726- } \\
1874\end{array}$ & $\begin{array}{l}\text { Cited lines are NOT supported by SDD } \\
\text { Appendix F. This code is almost } \\
\text { exactly the same as the code for the next } \\
\text { location in the SDD Appendix F } \\
\text { 'N_NCRSL' }\end{array}$ & $\begin{array}{l}\text { Additional functionality is } \\
\text { performed. Messages are } \\
\text { sent which are not } \\
\text { required by SDD } \\
\text { Appendix F }\end{array}$ & \\
\hline
\end{tabular}




\begin{tabular}{|c|c|c|c|c|}
\hline $\begin{array}{l}\text { APPENDIX F DESIGN } \\
\text { (PROCESS 3.1.8) }\end{array}$ & DESIGN CONTENT & DISCREPANCY & $\begin{array}{l}\text { RATIONALE FOR } \\
\text { CATEGORY }\end{array}$ & RESOLUTION \\
\hline $\begin{array}{l}\text { UP34: Box at NDE vault } \\
\text { scale }\end{array}$ & PCSDMS.PC: lines 2683-2743 & $\begin{array}{l}\text { There are } 170 \text { lines of code commented } \\
\text { out for this section. There is a comment } \\
\text { that states the DMSBWA DD message } \\
\text { needs to be defined. The code is for a } \\
\text { DMSSIE DD message which will need } \\
\text { to be modified }\end{array}$ & $\begin{array}{l}\text { The SDD is lacking } \\
\text { design definition. Not } \\
\text { clear as of this review } \\
\text { whether design issue has } \\
\text { been resolved and code is } \\
\text { included in Phase } 1 \\
\text { implementation }\end{array}$ & \\
\hline $\begin{array}{l}\text { UP39: Waste containers } \\
\text { have been accepted into } \\
\text { WRAP at the receiving } \\
\text { dock }\end{array}$ & \multirow[t]{2}{*}{ PCSDMS.PC } & $\begin{array}{l}\text { Not identified where DMSSO101 calls } \\
\text { this function. This function is defined in } \\
\text { two modules: PCSECHO.C and } \\
\text { MSCDMSPC.C and is different in each }\end{array}$ & $\begin{array}{l}\text { The wrong module might } \\
\text { be called. Potential } \\
\text { source code maintenance } \\
\text { problem }\end{array}$ & \\
\hline $\begin{array}{l}\text { UP40: PIN of waste drum } \\
\text { at the LLW or TRU entry } \\
\text { glovebox sent to the PCS }\end{array}$ & & $\begin{array}{l}\text { The code for the LLW_ENTRY is in } \\
\text { sync with the SDD, but the code for } \\
\text { TRU_ENTRY is commented out. The } \\
\text { TRUEENTRY code is not in sync with } \\
\text { the SDD }\end{array}$ & $\begin{array}{l}\text { Functionality has not been } \\
\text { implemented. Appendix } \\
\text { F indicates this is a Phase } \\
\text { I development. However, } \\
\text { para } 2.0 \text { of the SDD } \\
\text { indicates TRU is a later } \\
\text { Phase process. Need to } \\
\text { confirm the necessity for } \\
\text { this function in the } \\
\text { appropriate phase }\end{array}$ & . \\
\hline
\end{tabular}




\begin{tabular}{|c|c|c|c|c|}
\hline $\begin{array}{l}\text { APPENDIX F DESIGN } \\
\text { (PROCESS 3.1.8) }\end{array}$ & DESIGN CONTENT & DISCREPANCY & $\begin{array}{l}\text { RATIONALE FOR } \\
\text { CATEGORY }\end{array}$ & RESOLUTION \\
\hline $\begin{array}{l}\text { UP41: PINs of drums or } \\
\text { boxes shipped from WRAP } \\
\text { sent to PCS }\end{array}$ & & $\begin{array}{l}\text { Not identified where DMSS0602 calls } \\
\text { this function. This function is defined in } \\
\text { two modules: PCSECHO.C and } \\
\text { MSCDMSPC.C and is different in each. }\end{array}$ & $\begin{array}{l}\text { Implementation of SDD } \\
\text { may be missing. The } \\
\text { wrong module might be } \\
\text { called. Potential source } \\
\text { code maintenance problem }\end{array}$ & \\
\hline $\begin{array}{l}\text { UP60: Drum } \\
\text { Contamination Status } \\
\text { message from PCS }\end{array}$ & PCSDMS.PC: lines 5418-5422 & $\begin{array}{l}\text { The lines } 5418-5422 \text { are additional } \\
\text { features not specified in the SDD }\end{array}$ & $\begin{array}{l}\text { Additional functionality } \\
\text { may interfere with proper } \\
\text { operation }\end{array}$ & \\
\hline $\begin{array}{l}\text { UP62: Request for BWAS } \\
\text { Status to BWAS }\end{array}$ & PCSDMS.PC: line 7816 & $\begin{array}{l}\text { Function ora_dmsrbwa_rbwa only logs } \\
\text { the message. It does not send anything }\end{array}$ & \multirow[t]{2}{*}{$\begin{array}{l}\text { Implementation of SDD } \\
\text { may be missing }\end{array}$} & \\
\hline $\begin{array}{l}\text { UP63: BWAS Status from } \\
\text { BWAS }\end{array}$ & PCSDMS.PC: line 7447 & $\begin{array}{l}\text { Function ora_bwadms_sbwa only logs } \\
\text { the message. It does not send anything }\end{array}$ & & \\
\hline $\begin{array}{l}\text { UP65: Request for Abort } \\
\text { BWAS Assay from PCS }\end{array}$ & \multirow[t]{2}{*}{ PCSDMS.PC } & $\begin{array}{l}\text { Function ora pcrdms_abwa only logs the } \\
\text { message. It does not send a } \\
\text { DMSBWAS ABWA nor a DMSRBWA } \\
\text { ABWA }\end{array}$ & \multirow[t]{2}{*}{$\begin{array}{l}\text { Assay not aborted when } \\
\text { requested }\end{array}$} & \\
\hline $\begin{array}{l}\text { UP66: Request for Abort } \\
\text { BWAS Assay to BWAS }\end{array}$ & & $\begin{array}{l}\text { Function ora_dmsrbwa_abwa only logs } \\
\text { the message. It does not send anything. } \\
\text { Where ora_dmsrbwa_abwa is called } \\
\text { from cannot be found }\end{array}$ & & \\
\hline
\end{tabular}




\begin{tabular}{|c|c|c|c|c|}
\hline $\begin{array}{l}\text { APPENDIX F DESIGN } \\
\text { (PROCESS 3.1.8) }\end{array}$ & DESIGN CONTENT & DISCREPANCY & $\begin{array}{l}\text { RATIONALE FOR } \\
\text { CATEGORY }\end{array}$ & RESOLUTION \\
\hline $\begin{array}{l}\text { UP74: Criticality Alert } \\
\text { from BWAS }\end{array}$ & MSGDMSPC.C & $\begin{array}{l}\text { Function ora_bwadms_crit logs the } \\
\text { message and calls } \\
\text { dmspcs_criticality_alert() in module } \\
\text { MSGDMSPC.C. Where } \\
\text { ora_bwadms_crit is called from cannot } \\
\text { be found }\end{array}$ & $\begin{array}{l}\text { Implementation of SDD } \\
\text { may be missing }\end{array}$ & \\
\hline
\end{tabular}




\begin{tabular}{|c|c|c|c|c|}
\hline $\begin{array}{l}\text { APPENDIX F DESIGN } \\
\text { (PROCESS 3.1.8) }\end{array}$ & DESIGN CONTENT & DISCREPANCY & $\begin{array}{l}\text { RATIONALE FOR } \\
\text { CATEGORY }\end{array}$ & RESOLUTION \\
\hline \multicolumn{5}{|c|}{ CATEGORY 3 DISCREPANCIES } \\
\hline UP1: Log all Messages & & String is delimited with " " not "^" & $\begin{array}{l}\text { A programmer might } \\
\text { write a routine that } \\
\text { incorrectly parses the } \\
\text { message }\end{array}$ & \multirow{4}{*}{$\begin{array}{l}\text { Message code validated } \\
\text { during testing. Revised } \\
\text { specifications to be published } \\
\text { as new baseline with "as- } \\
\text { built" SDD revision. } \\
\text { Discrepancy item closed }\end{array}$} \\
\hline \multirow[t]{3}{*}{$\begin{array}{l}\text { UP2: Drum or Box } \\
\text { Location from PCS }\end{array}$} & PCSDMS.PC: lines 1143-1145 & $\begin{array}{l}\text { In thes lines is a discussion between two } \\
\text { programmers discussing how something } \\
\text { should be implemented - code } \\
\text { commented out }\end{array}$ & $\begin{array}{l}\text { Implementation of SDD is } \\
\text { unclear and may be } \\
\text { missing. As of this } \\
\text { review, not known if issue } \\
\text { is resolved }\end{array}$ & \\
\hline & PCSDMS.PC: lines 1089-1099 & $\begin{array}{l}\text { Two additional parameters are passed: } \\
\text { message - as sent or received across } \\
\text { TCP/IP } \\
\text { msg_length - number of bytes of the } \\
\text { message } \\
\text { Field numbers are correct when two is } \\
\text { added to them. }\end{array}$ & $\begin{array}{l}\text { Functionality may exceed } \\
\text { SDD intent, or SDD } \\
\text { should be updated }\end{array}$ & \\
\hline & PCSDMS.PC: lines 1016-1027 & $\begin{array}{l}\text { Message } 1001 \text { is not logged. Message } \\
1007 \text { is not logged, but Message } 1008 \text {, } \\
\text { which is not in the SDD, is logged. }\end{array}$ & $\begin{array}{l}\text { Should be checked to see } \\
\text { if this is simply a typo in } \\
\text { the code or Appendix F }\end{array}$ & \\
\hline
\end{tabular}




\begin{tabular}{|c|c|c|c|c|}
\hline $\begin{array}{l}\text { APPENDIX F DESIGN } \\
\text { (PROCESS 3.1.8) }\end{array}$ & DESIGN CONTENT & DISCREPANCY & $\begin{array}{l}\text { RATIONALE FOR } \\
\text { CATEGORY }\end{array}$ & RESOLUTION \\
\hline . & $\begin{array}{l}\text { PCSDMS.PC: lines 1111-1206 } \\
\ldots\end{array}$ & $\begin{array}{l}\text { SDD says to flag and report an } \\
\text { unrecognized location and drum/box } \\
\text { PIN. Actually, DMSCOM insures there } \\
\text { is a row in CONLOC. If an invalid } \\
\text { package ID is passed, DMSCOM will } \\
\text { create a row in CONLOC rather than } \\
\text { flag an error }\end{array}$ & $\begin{array}{l}\text { Should ensure entry of } \\
\text { new record desirable - or } \\
\text { if unknown drum should } \\
\text { be rejected and not } \\
\text { allowed until discrepancy } \\
\text { resolved }\end{array}$ & \\
\hline $\begin{array}{l}\text { UP6: Drum(s) removed } \\
\text { from AS/RS }\end{array}$ & PCSDMS.PC: lines 1244-1247 & $\begin{array}{l}\text { In addition to the SDD Appendix F } \\
\text { specification, an error } 1008 \text { is logged if } \\
\text { an Oracle } 1403 \text { error is detected }\end{array}$ & \multirow[t]{4}{*}{$\begin{array}{l}\text { Functionality may exceed } \\
\text { SDD intent, or SDD } \\
\text { should be updated }\end{array}$} & \\
\hline $\begin{array}{l}\text { UP9: Drum at LLW Entry } \\
\text { Glovebox Port } \\
\text { UP10: Drum at LLW } \\
\text { Entry Glove Box Port }\end{array}$ & PCSDMS.PC: lines $679-732$ & $\begin{array}{l}\text { The Container extension table rows are } \\
\text { copied in the same fashion }\end{array}$ & & \\
\hline \multirow{2}{*}{$\begin{array}{l}\text { UP29: Drum or Box } \\
\text { Location with Weight from } \\
\text { PCS }\end{array}$} & \multirow[t]{2}{*}{ PCSDMS.PC } & $\begin{array}{l}\text { Two additional parameters are passed: } \\
\text { message and msg_length }\end{array}$ & & \\
\hline & & $\begin{array}{l}\text { Message } 1008 \text { is logged. None of the } \\
\text { other messages is logged }\end{array}$ & & \\
\hline
\end{tabular}




\begin{tabular}{|c|c|c|c|c|}
\hline $\begin{array}{l}\text { APPENDIX F DESIGN } \\
\text { (PROCESS 3.1.8) }\end{array}$ & DESIGN CONTENT & DISCREPANCY & $\begin{array}{l}\text { RATYONALE FOR } \\
\text { CATEGORY }\end{array}$ & RESOLUTION \\
\hline $\begin{array}{l}\text { UP44: RW Packet and } \\
\text { Transfer Drum relationship } \\
\text { from PCS } \\
\text { UP46: RW Packet and } \\
\text { Parent Drum relationship } \\
\text { from PCS }\end{array}$ & & $\begin{array}{l}\text { Two additional parameters are passed: } \\
\text { Message: as sent or received across } \\
\text { TCP/IP } \\
\text { msg_length: number of bytes of the } \\
\text { messages. } \\
\text { The field numbers are correct when two } \\
\text { is added to then }\end{array}$ & & \\
\hline
\end{tabular}




\subsection{SCREEN SOURCE CODE REVIEW}

\subsubsection{Purpose}

This analysis compares the source code for the DMS Phase 1 screens with the SDD specifications to determine if the screens will perform as specified.

\subsubsection{Scope} DMS screens:

This analysis compared the SDD Appendix F specifications with the source code for

DMSS0101 Container Receiving

DMSS0201 NDE Screen

DMSS0202 NDA Screen

DMSS0311 LLW Drum Status at Entry

DMSS0312 LLW Sorting Table

DMSS0315 Some Waste Records

DMSS0602 Loading Dock Container Shipping

DMSS0901 Processing List Additions

DMSS0902 Process Pick List

DMSS0903 AS/RS Storage Pick List

DMSS0904 AS/RS Shipping Pick List

DMSS1101 Radiological Inventory Summary

DMSS1221 Processed Waste Data Review/Modification

\subsubsection{Description of Analysis Approach}

For this analysis, matrices were prepared for each screen showing the screen name, the code source to implement the screen functions, and comments regarding how these compare to the SDD Appendix F specifications. Where discrepancies are noted, they are categorized according to their severity. (See the Introduction section of this V\&V Report for a definition of discrepancy categories.)

Due to the quantity of source code, the matrices only contain cases where source code and specifications are not in complete agreement. Code lines and Appendix $\mathrm{F}$ design features not mentioned are considered to be acceptable as specified. 


\subsubsection{Analytic Overview}

\subsubsection{General Observations}

In addition to the comments and discrepancies noted in the matrices, the following general comments are noted:

Category 2 concerns:

SDD contents:

- SDD does not specify display of date \& time.

- SDD does not specify when screen objects, (buttons, fields, check boxes, etc...) are active or inactive.

- SDD does not specify Pop-up List of Values.

- SDD does not specify screen colors.

\subsubsection{Discrepancy Synopsis and Resolution Matrices}

The following matrix contains a synopsis of the discrepancies which are described in more detail in the analytic matrices found in the DMS project files. This synopsis groups the discrepancies by category. It then provides resolution actions which were decided during the course of the V\&V analysis. Those actions which are closed are also noted.

The resolution matrix will be considered a tracking mechanism to monitor all discrepancies until they are closed. Consequently, it will be periodically updated to reflect closed actions. If requirements are changed during the DMS development, these changes will be noted in the resolution matrix as pending actions and tracked as with any other actions. 
(Note: as of September 27, 1996, these discrepancies have been provided to the developer. Due to the urgency of workload, not all resolution actions were reported back to the V\&V Analysts by the development team. Those that were are noted in the following matrix. For the remaining discrepancies, the DMS functional testing should be considered to superscede this report. Where discrepancies were obviously corrected by the development team, as verified during the testing and acceptance of the system modules, this result was considered as closure on those discrepancies. Resolution comments indicate where this was the case.)

\begin{tabular}{|c|c|c|c|c|}
\hline SCREEN & CODE/SCREEN FEATURE & DISCREPANCY & $\begin{array}{l}\text { RATIONALE FOR } \\
\text { CATEGORY }\end{array}$ & RESOLUTION \\
\hline \multicolumn{5}{|c|}{ CATEGORY 1 DISCREPANCIES } \\
\hline $\begin{array}{l}\text { DMS\$0101 - Facility } \\
\text { curie limit check }\end{array}$ & . & $\begin{array}{l}\text { Cannot determine if Pop-up } \\
\text { message "Facility Radiological } \\
\text { Inventory limit has been } \\
\text { exceeded" is being executed. }\end{array}$ & $\begin{array}{l}\text { If this feature is not } \\
\text { implemented a safety } \\
\text { hazard could occur }\end{array}$ & $\begin{array}{l}\text { 2/20/96: Test Proc Review } \\
\text { Meet: need to confirm that } \\
\text { update happens. } \\
\text { Follow-on Test Results: } \\
\text { DMS-F12 tests this feature } \\
\text { and it passed. Discrepancy } \\
\text { Item Closed }\end{array}$ \\
\hline
\end{tabular}




\begin{tabular}{|c|c|c|c|c|}
\hline SCREEN & CODE/SCREEN FEATURE & DISCREPANCY & $\begin{array}{l}\text { RATIONALE FOR } \\
\text { CATEGORY }\end{array}$ & RESOLUTTION \\
\hline $\begin{array}{l}\text { DMSSO101 - Retrieve } \\
\text { drum or box data from } \\
\text { SWITS }\end{array}$ & Request Button & $\begin{array}{l}\text { Cannot determine if a check } \\
\text { for signature password is } \\
\text { performed. }\end{array}$ & $\begin{array}{l}\text { Can not verify this } \\
\text { feature has been } \\
\text { implemented }\end{array}$ & $\begin{array}{l}\text { 2/20/96: Test Proc Review } \\
\text { Meet: signature password } \\
\text { routine used in programs } \\
\text { should be verified - seems to } \\
\text { be multiple names BCSR E- } \\
\text { MAIL of } 2 / 22 / 96 \text { : all } \\
\text { should be using } \\
\text { PERFORM ROLE } \\
\text { SECURTY routine in the } \\
\text { PRE COMMIT trigger - } \\
\text { there are some old version } \\
\text { routines which are } \\
\text { supposed to be named } \\
\text { differently and are not } \\
\text { used - will watch for any } \\
\text { cases where wrong routine } \\
\text { used - Discrepancy Item } \\
\text { Closed }\end{array}$ \\
\hline
\end{tabular}




\begin{tabular}{|c|c|c|c|c|}
\hline SCREEN & CODE/SCREEN FEATURE & DISCREPANCY & $\begin{array}{l}\text { RATIONALE FOR } \\
\text { CATEGORY }\end{array}$ & RESOLUTION \\
\hline & insert_wastext() & $\begin{array}{l}\text { The form places the cursor to } \\
\text { recdisp.recdisp_inner_pck_id } \\
\text { and presents a Pop-up of route } \\
\text { codes. This is not in the SDD. } \\
\text { The screen print for this screen } \\
\text { does not show a field for route } \\
\text { code. }\end{array}$ & $\begin{array}{l}\text { This is a feature not } \\
\text { specified in the design } \\
\text { document }\end{array}$ & $\begin{array}{l}\text { 2/20/96: Test Proc Review } \\
\text { Meet: a pending SCR may } \\
\text { cause a need for an update to } \\
\text { the SDD } \\
\text { Follow-on Test Results:. } \\
\text { DMS-F } 12 \text { tests this feature } \\
\text { and it passed. - Inner PIN is } \\
\text { not updatable by the user. It } \\
\text { is only filled in on [Confirm } \\
\text { Data]. Therefore no route } \\
\text { code popup appears when the } \\
\text { field is chosen. This is } \\
\text { consistent with the Current } \\
\text { SDD. As-built status for } \\
\text { SRS/SDD unknown. } \\
\text { Discrepancy Item Closed }\end{array}$ \\
\hline . & i_isogty_swits() & $\begin{array}{l}\text { The SDD states "Only } \\
\text { download those ISOQTY } \\
\text { tecords with } \\
\text { ISO_WRAP_FLAG = 'Y'" } \\
\text { This test is not performed. All } \\
\text { ISOQTY records are } \\
\text { downloaded for a given } \\
\text { package id. }\end{array}$ & $\begin{array}{l}\text { DMS might not be able } \\
\text { to process the additional } \\
\text { ISOQTY records }\end{array}$ & $\begin{array}{l}\text { 2/20/96: Test Proc Review } \\
\text { Meet: test and associated } \\
\text { data element are overtaken } \\
\text { by events (see discussion in } \\
\text { mapping of Appendix C to } \\
\text { Appendix F) - dropped from } \\
\text { specs } \\
\text { Discrepancy Item Closed }\end{array}$ \\
\hline
\end{tabular}




\begin{tabular}{|c|c|c|c|c|}
\hline SCREEN & CODE/SCREEN FEATURE & DISCREPANCY & $\begin{array}{l}\text { RATIONALE FOR } \\
\text { CATEGORY }\end{array}$ & RESOLUTION \\
\hline $\begin{array}{l}\text { DMSS0201 - Drum or } \\
\text { Box NDE Certification } \\
\text { Data }\end{array}$ & Table names in source code & $\begin{array}{l}\text { The tables are referenced via } \\
\text { WRAPADM.tablename instead } \\
\text { of the table name directly. }\end{array}$ & $\begin{array}{l}\text { The wrong table might be } \\
\text { referenced }\end{array}$ & $\begin{array}{l}\text { 2/22/96: Test Proc Review } \\
\text { Meet: need to drop } \\
\text { WRAPADM - it's a matter } \\
\text { of how pulled during } \\
\text { programming }\end{array}$ \\
\hline \multirow[t]{3}{*}{$\begin{array}{l}\text { DMSS0202 - NDA Data } \\
\text { Review in the Control } \\
\text { Room }\end{array}$} & DMS transmit DMSSIE DD message & $\begin{array}{l}\text { ABUN portion of DMSSIE DD } \\
\text { message is not sent. }\end{array}$ & $\begin{array}{l}\text { Message may not be } \\
\text { generated with correct } \\
\text { content }\end{array}$ & $\begin{array}{l}\text { 2/22/96: Test Proc Review } \\
\text { Meet: need to clarify with } \\
\text { BNFL - ABUN is probably } \\
\text { needed but need to know } \\
\text { what SIE has }\end{array}$ \\
\hline & DMS transmit DMSSIE DD message & $\begin{array}{l}\text { Cannot find where } \\
\text { MSGLOG_FLAG is set to } \\
\text { 'FD'. }\end{array}$ & $\begin{array}{l}\text { May not have complete } \\
\text { processing }\end{array}$ & $\begin{array}{l}\text { 2/22/96: Test Proc Review } \\
\text { Meet: need to remove spec } \\
\text { from SDD }\end{array}$ \\
\hline & Table names in source code & $\begin{array}{l}\text { The tables are referenced via } \\
\text { WRAPADM.tablename instead } \\
\text { of the table name directly. }\end{array}$ & $\begin{array}{l}\text { The wrong table might be } \\
\text { referenced }\end{array}$ & $\begin{array}{l}\text { 2/22/96: Test Proc Review } \\
\text { Meet: need to drop } \\
\text { WRAPADM - it's a matter } \\
\text { of how pulled during } \\
\text { programming }\end{array}$ \\
\hline
\end{tabular}




\begin{tabular}{|c|c|c|c|c|}
\hline SCREEN & CODE/SCREEN FEATURE & DISCREPANCY & $\begin{array}{l}\text { RATIONALE FOR } \\
\text { CATEGORY }\end{array}$ & RESOLUTION \\
\hline \multirow[t]{2}{*}{$\begin{array}{l}\text { DMSS0312 - LLW } \\
\text { Sorting Table }\end{array}$} & $\begin{array}{l}\text { Request screen from LLW Process } \\
\text { menu }\end{array}$ & $\begin{array}{l}\text { SDD Appendix F specifies if } \\
\text { LLW_SORT not found create a } \\
\text { new record that will be } \\
\text { modified during this process. } \\
\text { As implemented: if } \\
\text { LLW_SORT not found exit } \\
\text { form. }\end{array}$ & $\begin{array}{l}\text { Feature may not have } \\
\text { been designed and/or } \\
\text { implemented correctly }\end{array}$ & \multirow[t]{4}{*}{$\begin{array}{l}\text { Screen code validated during } \\
\text { testing. Revised } \\
\text { specification to be published } \\
\text { as new baseline with "as- } \\
\text { built" SDD revision. } \\
\text { Discrepancy item closed }\end{array}$} \\
\hline & & $\begin{array}{l}\text { The SDD does not specify how } \\
\text { to select the puck record. }\end{array}$ & & \\
\hline $\begin{array}{l}\text { DMSS0312 - Sample } \\
\text { Button }\end{array}$ & sample_btn & $\begin{array}{l}\text { The code to call screen } \\
\text { DMSS0501 is commented out. } \\
\text { This function is not performed. }\end{array}$ & $\begin{array}{l}\text { Sample screen } \\
\text { DMSSOS01 cannot be } \\
\text { called from DMSSO312 }\end{array}$ & \\
\hline $\begin{array}{l}\text { DMSS0315 - Sum Waste } \\
\text { Records }\end{array}$ & SUM_WASTE_RECORDS & $\begin{array}{l}\text { The SDD states-- } \\
\text { DIVIDE PHYSCOMP_VAR } \\
\text { by PHYSCOMP_HGT for each } \\
\text { PHYSCOMP_DESCR and } \\
\text { STORE to product drum } \\
\text { PHYS_COMP_VOL_PCT. } \\
\text { This is not implemented. }\end{array}$ & $\begin{array}{l}\text { Not sure if feature has } \\
\text { been designed and/or } \\
\text { implemented correctly }\end{array}$ & \\
\hline
\end{tabular}


WRAP I DMS VALIDATION AND VERIFICATION REPORT
HNF-1783

Revision 0

September 27, 1996

\begin{tabular}{|c|r|l|l|l|}
\hline SCREEN & CODE/SCREEN FEATURE & DISCREPANCY & $\begin{array}{c}\text { RATIONALE FOR } \\
\text { CATEGORY }\end{array}$ & Feature not implemented \\
\hline \hline & & $\begin{array}{l}\text { The SDD states-- } \\
\text { Combine waste records for } \\
\text { RADDETAIL, HAZDETAIL, } \\
\text { and CHEMCOMP in } \\
\text { accordance with SWITS } \\
\text { algorithms. } \\
\text { SwITS is not being accessed. }\end{array}$ & \\
\hline
\end{tabular}




\begin{tabular}{|c|c|c|c|c|}
\hline SCREEN & CODE/SCREEN FEATURE & DISCREPANCY & $\begin{array}{l}\text { RATTONALE FOR } \\
\text { CATEGORY }\end{array}$ & RESOLUTION \\
\hline . & $\begin{array}{l}\text { Results from WRAP NDA: } \\
\text { Create NDA record for } \\
\text { NDA_PKG_ID = CONLOC } \\
\text { PKG_D_where CONLOC } \\
\text { LOCN_ID = 'LLW_EXIT' } \\
\text { Set NDA_DT = current system date } \\
\text { Set NDA_ASSAY_NUM = 'CALC' } \\
\text { Set NDA__SWTY__GROUP = } \\
\text { 'LLW' } \\
\text { Set NDA_TOr_PE_CI = } \\
\text { sum of NDA_TOT_PE_CI } \\
\text { for pucks } \\
\text { Set NDA_TOT_PU_FGE = } \\
\text { sum ofNDA_TOT_PU_FGE } \\
\text { for pucks_- } \\
\text { Set NDA_TOT_ALPHA_CI } \\
\text { = sum of NDA_TOT_- } \\
\text { ALPHA_CI for pucks } \\
\text { Set NDA_TOT_THERMAL_- } \\
\text { POWER = sum of NDA } \\
\text { TOT_THERMAL_POWER } \\
\text { for pucks multiplied by ratio } \\
\text { 7.35/11.36 }\end{array}$ & $\begin{array}{l}\text { The SDD states the-- } \\
\text { NDA results need to be } \\
\text { summed for each puck in the } \\
\text { product drum (the latest puck } \\
\text { assays are to be used if more } \\
\text { than one assay exists for a } \\
\text { single puck) and store the } \\
\text { results into the product drum } \\
\text { NDAISO (Table). } \\
\text { This is not being performed. }\end{array}$ & & \\
\hline
\end{tabular}




\begin{tabular}{|c|c|c|c|c|}
\hline SCREEN & CODE/SCREEN FEATURE & DISCREPANCY & $\begin{array}{l}\text { RATIONALE FOR } \\
\text { CATEGORY }\end{array}$ & RESOLUTION \\
\hline & $\begin{array}{l}\text { Results from WRAP NDA. } \\
\text { (continued) } \\
\text { Sum NDAISO_QTY } \\
\text { Set NDAISO_QTY_TMU: } \\
\text { Create a temporary variable for each } \\
\text { isotope = the sum of the inverse of } \\
\text { all puck TMUs squared for that } \\
\text { isotope. Take the square root of the } \\
\text { inverse of the temporary variable } \\
\text { and set the NDAISO_QTY_TMU for } \\
\text { the outer drum equal to that result. } \\
\text { NOTE: This assigns the square root } \\
\text { of the sum of the squares for the } \\
\text { product drum TMU. } \\
\text { NDAISO_DT = NDA_DT } \\
\text { NOTE: This assigns the NDA } \\
\text { record date for the product drum to } \\
\text { the NDAISO record WRAPMISC } \\
\text { Table and sets } \\
\text { CONEXT_PROF_FLAG = 'Y' for } \\
\text { the product drum only }\end{array}$ & - & & $\cdot$ \\
\hline
\end{tabular}




\begin{tabular}{|c|c|c|c|c|}
\hline SCREEN & CODE/SCREEN FEATURE & DISCREPANCY & $\begin{array}{l}\text { RATIONALE FOR } \\
\text { CATEGORY }\end{array}$ & RESOLUTION \\
\hline & 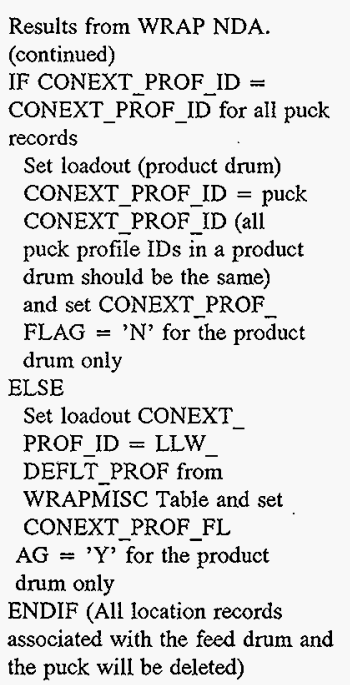 & & & \\
\hline
\end{tabular}




\begin{tabular}{|c|c|c|c|c|}
\hline SCREEN & CODE/SCREEN FEATURE & DISCREPANCY & $\begin{array}{l}\text { RATIONALE FOR } \\
\text { CATEGORY }\end{array}$ & RESOLUTION \\
\hline \multirow[t]{2}{*}{$\begin{array}{l}\text { DMSS0602 - Loading } \\
\text { Dock Container Shipping }\end{array}$} & Function update_swits_btn button & $\begin{array}{l}\text { Functions } \\
\text { insert_swits_pkgdw(), } \\
\text { insert_swits_shipment(), } \\
\text { insert_swits_shipitem(), } \\
\text { insert_swits_shiphist(), } \\
\text { insert_swits_verification() are } \\
\text { commented out. A comment } \\
\text { states: "procedures } \\
\text { swqits_pkgdw, shipment, } \\
\text { shipitem, shiphist and } \\
\text { verification won't work until } \\
\text { those tables database function } \\
\text { (602_db.functions) for those } \\
\text { tables are created on DMS." }\end{array}$ & \multirow[t]{2}{*}{$\begin{array}{l}\text { Not sure if feature has } \\
\text { been designed and/or } \\
\text { implemented correctly }\end{array}$} & $\begin{array}{l}\text { 05/01/96: Test Proc Review } \\
\text { Meet: These are upper level } \\
\text { data base functions stored in } \\
\text { the database } \\
\text { Discrepancy Item Closed }\end{array}$ \\
\hline & Function in_transit_btn button & $\begin{array}{l}\text { This function first sends PCS a } \\
\text { CL message of IN_TRANSIT. } \\
\text { Then updates SWITS. If the } \\
\text { update of SWITS fails are the } \\
\text { drums still shipped? }\end{array}$ & & $\begin{array}{l}\text { 05/01/96: Test Proc Review } \\
\text { Meet: still flagged as } \\
\text { IN_TRANSIT even if } \\
\text { SWITS update fails - record } \\
\text { would not be updated and } \\
\text { would still be noted as } \\
\text { needing closeout } \\
\text { Discrepancy Item Closed }\end{array}$ \\
\hline
\end{tabular}




\begin{tabular}{|c|c|c|c|c|}
\hline SCREEN & CODE/SCREEN FEATURE & DISCREPANCY & $\begin{array}{l}\text { RATIONALE FOR } \\
\text { CATEGORY }\end{array}$ & RESOLUTION \\
\hline & Send Picklist Button & $\begin{array}{l}\text { The SDD states } \\
\text { signature/password is required } \\
\text { for this function. However, } \\
\text { the check is not implemented. }\end{array}$ & & $\begin{array}{l}\text { 05/01/96: Test Proc Review } \\
\text { Meet: signature password is } \\
\text { checked for IN_TRANSIT } \\
\text { and COMMIT - SDD needs } \\
\text { to be updated }\end{array}$ \\
\hline \multirow[t]{2}{*}{$\begin{array}{l}\text { DMSS0901 - Process } \\
\text { List Additions }\end{array}$} & Resequence Button & $\begin{array}{l}\text { Instead of executing the } \\
\text { resequence_procadd procedure } \\
\text { the adjust_seq_num procedure } \\
\text { is executed. }\end{array}$ & & $\begin{array}{l}\text { 2/20/96: Test Proc Review } \\
\text { Meet: purpose of functions } \\
\text { to be reviewed and ensure } \\
\text { the proper one is being } \\
\text { called BCSR E-MAIL of } \\
\text { 2/22/96: review complete - } \\
\text { name of function called can } \\
\text { be adjusted later - not } \\
\text { currently a problem "if it } \\
\text { ain't broke, don't fix it" - } \\
\text { for purposes of } V \& V \text { in } \\
\text { support of Phase } 1 \text {, } \\
\text { Discrepancy Item Closed }\end{array}$ \\
\hline & Resequence _procadd & Not attached to a trigger. & & $\begin{array}{l}\text { 2/20/96: Test Proc Review } \\
\text { Meet: OK as coded } \\
\text { Discrepancy Item Closed }\end{array}$ \\
\hline
\end{tabular}




\begin{tabular}{|c|c|c|c|c|}
\hline SCREEN & CODE/SCREEN FEATURE & DISCREPANCY & $\begin{array}{l}\text { RATIONALE FOR } \\
\text { CATEGORY }\end{array}$ & RESOLUTION \\
\hline . & & $\cdot$ & $\begin{array}{l}\text { Form DMSS0901 can not } \\
\text { be used if DMSSO902 is } \\
\text { being used at the same } \\
\text { time. This is because } \\
\text { DMSS0902 has a table } \\
\text { lock on proclist and } \\
\text { DMSS0901 performs } \\
\text { insert and update } \\
\text { operations to this table. } \\
\text { There is no error } \\
\text { message displayed in the } \\
\text { "add to process list_btn" } \\
\text { routine for a table lock } \\
\text { condition in proclist }\end{array}$ & $\begin{array}{l}\text { 2/20/96: Test Proc Review } \\
\text { Meet: developer has put this } \\
\text { on list to research - generally } \\
\text { agreed there needs to be a } \\
\text { better approach }\end{array}$ \\
\hline
\end{tabular}




\begin{tabular}{|c|c|c|c|c|}
\hline SCREEN & CODE/SCREEN FEATURE & DISCREPANCY & $\begin{array}{l}\text { RATIONALE FOR } \\
\text { CATEGORY }\end{array}$ & RESOLUTION \\
\hline \multirow[t]{2}{*}{$\begin{array}{l}\text { DMSS0902 - Process } \\
\text { List Additions }\end{array}$} & Request screen from Pick List menu & $\begin{array}{l}\text { The SDD specifies the SQL } \\
\text { where clause as "where } \\
\text { CONLOC_PKG_ID < } \\
\text { PROC_PKG_ID AND } \\
\text { CONLOC_LOCN_ID = } \\
\text { 'AS_RS'AND } \\
\text { CONEXT_WRAP_STATUS_C } \\
D=\text { 'W'" } \\
\text { The Oracle form has "where } \\
\text { exists (select ' } \mathrm{x} \text { ' from wastext } \\
\text { where notproc_pkg_id = } \\
\text { conext_pkg_id and } \\
\text { conext_wrap_stat_cd = 'W'). }\end{array}$ & $\begin{array}{l}\text { system may not differ } \\
\text { from desired functionality }\end{array}$ & $\begin{array}{l}\text { 3/26/96: BCSR E-Mail: } \\
\text { verified that code is } \\
\text { supporting desire } \\
\text { functionality - "where" } \\
\text { clause is pseudo-code } \\
\text { Discrepancy Item Closed }\end{array}$ \\
\hline & & general conflict & $\begin{array}{l}\text { Form DMSS0901 can not } \\
\text { be used if DMSS0902 is } \\
\text { being used at the same } \\
\text { time. This is because } \\
\text { DMSS0902 has a table } \\
\text { lock on proclist and } \\
\text { DMSS0901 performs } \\
\text { insert and update } \\
\text { operations to this table }\end{array}$ & $\begin{array}{l}\text { Screen code validated during } \\
\text { testing. Revised } \\
\text { specifications to be published } \\
\text { as new baseline with "as- } \\
\text { built" SDD revision. } \\
\text { Discrepancy item closed }\end{array}$ \\
\hline
\end{tabular}




\begin{tabular}{|c|c|c|c|c|}
\hline SCREEN & CODE/SCREEN FEATURE & DISCREPANCY & $\begin{array}{l}\text { RATIONALE FOR } \\
\text { CATEGORY }\end{array}$ & RESOLUTION \\
\hline $\begin{array}{l}\text { DMSS0903 - AS/RS } \\
\text { Storage Pick List }\end{array}$ & [Retrieve Bin] Button & $\begin{array}{l}\text { The source code executes a } \\
\text { go_block('proclist') and a } \\
\text { go_block('notproclist'). These } \\
\text { blocks are not part of screen } \\
\text { DMSS0903. }\end{array}$ & \multirow[t]{4}{*}{$\begin{array}{l}\text { Not sure if feature has } \\
\text { been designed and/or } \\
\text { implemented correctly }\end{array}$} & $\begin{array}{l}03 / 26 / 96: \text { BCSR E-mail: } \\
\text { verified that 'proclist' and } \\
\text { 'notproclist' should be 'bin' } \\
\text { and 'discharge' - hold over } \\
\text { from "cut and paste" code - } \\
\text { needs to be deleted }\end{array}$ \\
\hline \multirow[t]{3}{*}{$\begin{array}{l}\text { DMSS1221: Processed } \\
\text { Waste Data } \\
\text { Review/Modifications }\end{array}$} & Data field RDET_HANDLING & $\begin{array}{l}\text { The source code references } \\
\text { field RDET_HANDLING in } \\
\text { the RADDETAIL table which } \\
\text { is not in the SDD data } \\
\text { dictionary. }\end{array}$ & & \multirow[t]{2}{*}{$\begin{array}{l}\text { Update to SDD: latest } \\
\text { revision of SDD includes } \\
\text { data element in the data } \\
\text { dictionary } \\
\text { Discrepancy Item Closed as } \\
\text { of } 3 / 26 / 96\end{array}$} \\
\hline & Data field RDET_RSWIMS_COUNT & $\begin{array}{l}\text { The source code references } \\
\text { field } \\
\text { RDET_RSWIMS COUNT in } \\
\text { the RADDETAIL table which } \\
\text { is not in the SDD data } \\
\text { dictionary. }\end{array}$ & & \\
\hline & Data field CON_DATA_QUAL_CD & $\begin{array}{l}\text { The source code references } \\
\text { field CON_DATA_QUAL_CD } \\
\text { in the WASTE table which is } \\
\text { not in the SDD data dictionary. }\end{array}$ & & $\begin{array}{l}\text { 06/06/96: Test Proc Review } \\
\text { Meet: old SWITS field that } \\
\text { has been left in the data base } \\
\text { as a "place holder" in case it } \\
\text { is needed later for future } \\
\text { interfaces } \\
\text { Discrepancy Item Closed }\end{array}$ \\
\hline
\end{tabular}




\begin{tabular}{|c|c|c|c|c|}
\hline SCREEN & CODE/SCREEN FEATURE & DISCREPANCY & $\begin{array}{l}\text { RATIONALE FOR } \\
\text { CATEGORY }\end{array}$ & RESOLUTION \\
\hline \multirow[b]{4}{*}{. } & Data field CON_GENER_ID & $\begin{array}{l}\text { The source code references } \\
\text { field CON_GENER_ID in the } \\
\text { WASTE table which is not in } \\
\text { the SDD data dictionary. }\end{array}$ & \multirow{4}{*}{. } & \multirow[t]{3}{*}{$\begin{array}{l}\text { 06/06/96: Test Proc Review } \\
\text { Meet: SDD needs to be } \\
\text { updated to include this field } \\
\text { in the data dictionary }\end{array}$} \\
\hline & Data field CON_GGRP_ID & $\begin{array}{l}\text { The source code references } \\
\text { field CON_GGRP ID in the } \\
\text { WASTE table which is not in } \\
\text { the SDD data dictionary. }\end{array}$ & & \\
\hline & Data field CON_WASTE_STREAM & $\begin{array}{l}\text { The source code references } \\
\text { field CON_WASTE_STREAM } \\
\text { in the WASTE table which is } \\
\text { not in the SDD data dictionary. }\end{array}$ & & \\
\hline & Data field HDET_SHIP_CD & $\begin{array}{l}\text { The source code references } \\
\text { field HDET_SHIP_CD in the } \\
\text { HAZDETAIL table which is } \\
\text { not in the SDD data dictionary. }\end{array}$ & & $\begin{array}{l}\text { 06/06/96: Test Proc Review } \\
\text { Meet: old SWITS field that } \\
\text { has been left in the data base } \\
\text { as a "place holder" in case it } \\
\text { is needed later for future } \\
\text { interfaces } \\
\text { Discrepancy Item Closed }\end{array}$ \\
\hline
\end{tabular}




\begin{tabular}{|c|c|c|c|c|}
\hline SCREEN & CODE/SCREEN FEATURE & DISCREPANCY & $\begin{array}{l}\text { RATIONALE FOR } \\
\text { CATEGORY }\end{array}$ & RESOLUTION \\
\hline \multicolumn{5}{|c|}{ CATEGORY 2 DISCREPANCIES } \\
\hline $\begin{array}{l}\text { DMSS0101 - Confirm } \\
\text { drums or boxes on } \\
\text { SWITS } \\
\text { Validate all required } \\
\text { SWITS fields }\end{array}$ & s_valid_swits () & $\begin{array}{l}\text { SDD lists } \\
\text { CON_LOCN_FACIL_AREA } \\
\text { as a required field. The code } \\
\text { is not verifying the existence of } \\
\text { data. }\end{array}$ & Unsure of impact & $\begin{array}{l}\text { 2/20/96: Test Proc Review } \\
\text { Meet: some of RELOC is to } \\
\text { be determined - SWITS has } \\
\text { already forced the data into } \\
\text { the data base - this may be } \\
\text { sufficient - needs review } \\
\text { Follow-on Test Results: } \\
\text { This is sufficient. DMS-F12 } \\
\text { tests verification of necessary } \\
\text { fields and they passed. } \\
\text { Discrepancy item closed }\end{array}$ \\
\hline $\begin{array}{l}\text { DMSSO101 - Retrieve } \\
\text { drum or box data from } \\
\text { SWITS }\end{array}$ & i_update_switso & $\begin{array}{l}\text { The function i_update_swits is } \\
\text { updating column } \\
\text { con_locn_facil_area to ' } 200 \mathrm{~W} \text { '. } \\
\text { This is ready done in function } \\
\text { u_swits } 0 \text {. }\end{array}$ & $\begin{array}{l}\text { This is redundant. This } \\
\text { could cause a software } \\
\text { maintenance problem }\end{array}$ & $\begin{array}{l}\text { 2/20/96: Test Proc Review } \\
\text { Meet: developer needs to } \\
\text { review to determine if both } \\
\text { needed } \\
\text { BCSR E-MAIL of } 2 / 22 / 96 \text { : } \\
\text { review complete - update } \\
\text { occurs for both inner and } \\
\text { outer drum - since not an } \\
\text { immediate apparent } \\
\text { problem, decision to leave } \\
\text { as i s for now - } \\
\text { Discrepancy Item Closed }\end{array}$ \\
\hline
\end{tabular}




\begin{tabular}{|c|c|c|c|c|}
\hline SCREEN & CODE/SCREEN FEATURE & DISCREPANCY & $\begin{array}{l}\text { RATIONALE FOR } \\
\text { CATEGORY }\end{array}$ & RESOLUTION \\
\hline $\begin{array}{l}\text { DMSS0101 - Commit } \\
\text { Button }\end{array}$ & do_key('commit_form') & $\begin{array}{l}\text { Cannot identify what is } \\
\text { performed during a commit } \\
\text { form. }\end{array}$ & \multirow[t]{5}{*}{$\begin{array}{l}\text { Not sure if feature has } \\
\text { been designed and/or } \\
\text { implemented correctly }\end{array}$} & $\begin{array}{l}\text { 2/20/96: Test Proc Review } \\
\text { Meet: need to review forms } \\
\text { book to see what goes over } \\
\text { commit }\end{array}$ \\
\hline \multirow[t]{4}{*}{ DMSS0101 - Exit Button } & exit_form Button & $\begin{array}{l}\text { The SDD states "saves or } \\
\text { delete RECDISP Data and } \\
\text { exit". This button does not } \\
\text { delete any records. There is a } \\
\text { "Delete Button" not specified } \\
\text { by the SDD. }\end{array}$ & & $\begin{array}{l}\text { 2/20/96: Test Proc Review } \\
\text { Meet: need to reword SDD } \\
\text { to change "delete". } \\
\text { Follow on resolution: SDD } \\
\text { OK on [Exit] button. } \\
\text { [Delete] button is a standard } \\
\text { function. } \\
\text { Discrepancy Item Closed }\end{array}$ \\
\hline & $\begin{array}{l}\text { Screen field } \\
\text { RECDISP_ERROR_STATUS }\end{array}$ & $\begin{array}{l}\text { The SDD does not specify this } \\
\text { field. It is a non-displayed } \\
\text { field with a Pop-up associated } \\
\text { with it. The Pop-up is not } \\
\text { specified in the SDD either. }\end{array}$ & & $\begin{array}{l}\text { 2/20/96: Test Proc Review } \\
\text { Meet: SDD needs to be } \\
\text { updated }\end{array}$ \\
\hline & $\begin{array}{l}\text { Screen field } \\
\text { RECDISP_INNER_PCK_ID }\end{array}$ & $\begin{array}{l}\text { The SDD does not specify an } \\
\text { LOV for this field. }\end{array}$ & & \multirow{2}{*}{$\begin{array}{l}\text { 2/20/96: Test Proc Review } \\
\text { Meet: status field should be } \\
\text { trigger - need to verify how } \\
\text { acting - what is causing Pop } \\
\text { up - update SDD }\end{array}$} \\
\hline & Screen field DISP_PCK_STATUS & $\begin{array}{l}\text { The SDD does not specify this } \\
\text { field. It is a non-displayed } \\
\text { field. }\end{array}$ & & \\
\hline
\end{tabular}




\begin{tabular}{|c|c|c|c|c|}
\hline SCREEN & CODE/SCREEN FEATURE & DISCREPANCY & $\begin{array}{l}\text { RATIONALE FOR } \\
\text { CATEGORY }\end{array}$ & RESOLUTION \\
\hline & Screen field DISP_ROUTE_CD & $\begin{array}{l}\text { The SDD does not specify this } \\
\text { field. It is a non-displayed } \\
\text { field with a Pop-up associated } \\
\text { with it. The Pop-up is not } \\
\text { specified in the SDD either. }\end{array}$ & & \\
\hline & Pop-up List of Values Button & $\begin{array}{l}\text { There are Pop-up List of } \\
\text { Values but no button to } \\
\text { activate. }\end{array}$ & & $\begin{array}{l}\text { 2/20/96: Test Proc Review } \\
\text { Meet: a "programmer } \\
\text { tweak" to make the system } \\
\text { work in a round about way - } \\
\text { triggering something needed } \\
\text { at that point }\end{array}$ \\
\hline \multirow[t]{2}{*}{$\begin{array}{l}\text { DMSS0201 - Drum or } \\
\text { Box NDE Certification } \\
\text { Data }\end{array}$} & SELECT ITEM Button & $\begin{array}{l}\text { The SDD does not have an } \\
\text { SELECT Button. The Screen } \\
\text { Print does not have an } \\
\text { SELECT Button. The source } \\
\text { code DOES have an SELECT } \\
\text { Button. }\end{array}$ & \multirow[t]{2}{*}{$\begin{array}{l}\text { Can not verify } \\
\text { implementation due to } \\
\text { lack of design } \\
\text { specification }\end{array}$} & $\begin{array}{l}\text { 2/20/96: Test Proc Review } \\
\text { Meet: need to change screen } \\
\text { print }\end{array}$ \\
\hline & CONLOC_LOCN_ID field & $\begin{array}{l}\text { The SDD does not mention the } \\
\text { display of this data. However, } \\
\text { implementation has it displayed } \\
\text { and editable. }\end{array}$ & & $\begin{array}{l}\text { 2/20/96: Test Proc Review } \\
\text { Meet: need to update } \\
\text { Appendix F }\end{array}$ \\
\hline
\end{tabular}




\begin{tabular}{|c|c|c|c|c|}
\hline SCREEN & CODE/SCREEN FEATURE & DISCREPANCY & $\begin{array}{l}\text { RATIONALE FOR } \\
\text { CATEGORY }\end{array}$ & RESOLUTION \\
\hline . & $\begin{array}{l}\text { Security check on the COMMIT } \\
\text { Button }\end{array}$ & $\begin{array}{l}\text { The function } \\
\text { perform_role_security is } \\
\text { commented out. }\end{array}$ & Security is not in place & $\begin{array}{l}\text { 2/20/96: Test Proc Review } \\
\text { Meet: commented out for } \\
\text { development and testing } \\
\text { purposes - comments will be } \\
\text { taken out when program } \\
\text { goes "live" Discrepancy } \\
\text { Item Closed }\end{array}$ \\
\hline \multirow{3}{*}{$\begin{array}{l}\text { DMSS0201 - Drum or } \\
\text { Box NDE Certification } \\
\text { DataDMSS0202 - NDA } \\
\text { Data Review in the } \\
\text { Control Room }\end{array}$} & Waste Record Pop-up & \multirow{3}{*}{$\begin{array}{l}\text { There is a wide disparity } \\
\text { between the data specified for } \\
\text { display and the actual data } \\
\text { elements being displayed by } \\
\text { the code }\end{array}$} & \multirow[t]{3}{*}{$\begin{array}{l}\text { Need to validate that the } \\
\text { "as built" code is } \\
\text { appropriate }\end{array}$} & \multirow{3}{*}{$\begin{array}{l}\text { 2/20/96: Test Proc Review } \\
\text { Meet: SDD will be updated } \\
\text { to "as built" - code is set up } \\
\text { to retrieve all table fields, } \\
\text { although only a smaller } \\
\text { number are actually ever } \\
\text { displayed - final screen } \\
\text { content has been approved - } \\
\text { code needs to be updated to } \\
\text { drop all unneeded fields }\end{array}$} \\
\hline & Radioactive Detail Record Pop-up & & & \\
\hline & $\begin{array}{l}\text { NDA Data Review in the Control } \\
\text { Room }\end{array}$ & & & \\
\hline $\begin{array}{l}\text { DMSSO202 - NDA Data } \\
\text { Review in the Control } \\
\text { Room }\end{array}$ & Display pop-up of PROFILE Table & $\begin{array}{l}\text { The SDD does not list any of } \\
\text { the fields to display. }\end{array}$ & $\begin{array}{l}\text { Can not verify } \\
\text { implementation due to } \\
\text { lack of design } \\
\text { specification }\end{array}$ & $\begin{array}{l}\text { 2/20/96: Test Proc Review } \\
\text { Meet: need to update } \\
\text { Appendix F to as-built spec - } \\
\text { uses an LOV button }\end{array}$ \\
\hline
\end{tabular}




\begin{tabular}{|c|c|c|c|c|}
\hline SCREEN & CODE/SCREEN FEATURE & DISCREPANCY & $\begin{array}{l}\text { RATIONALE FOR } \\
\text { CATEGORY }\end{array}$ & RESOLUTION \\
\hline & User select [NDA Results] & & & $\begin{array}{l}\text { 2/20/96: Test Proc Review } \\
\text { Meet: intent of Pop Up is to } \\
\text { display all fields in the table } \\
\text { Discrepancy Item Closed }\end{array}$ \\
\hline & User select [Isotopic Data] & & & $\begin{array}{l}\text { 2/20/96: Test Proc Review } \\
\text { Meet: intent of Pop Up is to } \\
\text { display all fields in NDAISO } \\
\text { table Discrepancy Item } \\
\text { Closed }\end{array}$ \\
\hline $\begin{array}{l}\text { DMSS0311 - LLW } \\
\text { Glovebox Drum Status at } \\
\text { Entry }\end{array}$ & validate_drum_entry & $\begin{array}{l}\text { A message is posted if there } \\
\text { are } 2 \text { or more drums. The } \\
\text { message is " } 2 \text { or more drums } \\
\text { at LLW Entry Lift Table". } \\
\text { This message is not specified } \\
\text { by the SDD. Further } \\
\text { processing for this screen is } \\
\text { halted. }\end{array}$ & $\begin{array}{l}\text { If the system detects } 2 \text { or } \\
\text { more drums at the LLW } \\
\text { Entry Lift Table } \\
\text { processing is stopped. } \\
\text { Manual intervention is } \\
\text { required }\end{array}$ & $\begin{array}{l}\text { 1/30/96: Test Proc Review } \\
\text { Meet: code should be } \\
\text { changed to address use of the } \\
\text { newest drum } \\
\text { Follow-on Test Results: } \\
\text { DMS-F11 test has been } \\
\text { successfully completed. This } \\
\text { message does not appear. } \\
\text { Only the newest PIN at that } \\
\text { location is displayed. SDD } \\
\text { OK. } \\
\text { Discrepancy item closed }\end{array}$ \\
\hline
\end{tabular}




\begin{tabular}{|c|c|c|c|c|}
\hline SCREEN & CODE/SCREEN FEATURE & DISCREPANCY & $\begin{array}{l}\text { RATIONALE FOR } \\
\text { CATEGORY }\end{array}$ & RESOLUTION \\
\hline & Screen field - INNER_PKG_ID & $\begin{array}{l}\text { The code allows editing this } \\
\text { field. This field is not saved. }\end{array}$ & $\begin{array}{l}\text { Not sure if feature has } \\
\text { been designed and/or } \\
\text { implemented correctly }\end{array}$ & $\begin{array}{l}\text { Follow-on Test Results: No } \\
\text { data entry is allowed from } \\
\text { this screen. Cursor can't } \\
\text { even be placed in any field. } \\
\text { SDD OK. } \\
\text { Discrepancy item Closed }\end{array}$ \\
\hline $\begin{array}{l}\text { DMSS0312 - LLW Non- } \\
\text { Compliant Screen }\end{array}$ & $\begin{array}{l}\text { DISP_MAT_GRP_CD } \\
\text { WHEN-VALIDATE-ITEM trigger }\end{array}$ & $\begin{array}{l}\text { The following code is present: } \\
\text { if :global.query_nc_packet = } \\
\text { 'N' then } \\
\text { update wastext } \\
\text { set conext_mat_grp_cd = } \\
\text { :nc_packet.disp_mat_grp_cd } \\
\text { where conext_pkg_id = } \\
\text { :nc_packet.con_pkg_id; } \\
\text { :nc_packet.con_gener_waste_de } \\
\text { scr : = } \\
\text { :nc_packet.con_gener_waste_de } \\
\text { scr; } \\
\text { else } \\
\text { :global.query_nc_packet : = } \\
\text { 'N' } \\
\text { end if }\end{array}$ & $\begin{array}{l}\text { 1. If the user validates } \\
\text { this field a second time } \\
\text { an update will occur. } \\
\text { 2. Unclear why } \\
\text { :nc_packet.con_gener_wa } \\
\text { ste_descr being set to its } \\
\text { own value. May need to } \\
\text { be set to another value } \\
\text { instead }\end{array}$ & $\begin{array}{l}\text { Screen code validated during } \\
\text { testing. Revised } \\
\text { specification to be published } \\
\text { as new baseline with "as- } \\
\text { built" SDD revision. } \\
\text { Discrepancy item closed }\end{array}$ \\
\hline
\end{tabular}




\begin{tabular}{|c|c|c|c|c|}
\hline SCREEN & CODE/SCREEN FEATURE & DISCREPANCY & $\begin{array}{l}\text { RATIONALE FOR } \\
\text { CATEGORY }\end{array}$ & RESOLUTION \\
\hline $\begin{array}{l}\text { DMSS0312 - Chemical } \\
\text { Component Screen } \\
\text { DMSS0312 - Physical } \\
\text { Component Screen }\end{array}$ & $\begin{array}{l}\text { No add, delete, refresh, or commit } \\
\text { button on pop-ups }\end{array}$ & $\begin{array}{l}\text { Commit done on parent } 0312 \\
\text { screen. Data updated when } \\
\text { user selects Return To Sorting } \\
\text { Table Screen button. Raises } \\
\text { question on how user verifies } \\
\text { data entry on pop-ups since } \\
\text { there is no "refresh" feed-back } \\
\text { prior to going to an upper level } \\
\text { screen for the final commit. }\end{array}$ & $\begin{array}{l}\text { Not sure if feature will } \\
\text { cause functional problems } \\
\text { - may want to consider a } \\
\text { Refresh button for these } \\
\text { two pop-ups which acts } \\
\text { like the Refresh button on } \\
\text { the Non-Compliant } \\
\text { screen }\end{array}$ & \\
\hline $\begin{array}{l}\text { DMSSO315 - Sum Waste } \\
\text { Records }\end{array}$ & RDET_VOID_CD & $\begin{array}{l}\text { The screen print does not show } \\
\text { RDET_VOID_CD. However, } \\
\text { it is in the SDD Appendix F } \\
\text { and it is implemented. }\end{array}$ & \multirow[t]{3}{*}{$\begin{array}{l}\text { Not sure if feature has } \\
\text { been designed and/or } \\
\text { implemented correctly }\end{array}$} & \\
\hline \multirow[t]{2}{*}{$\begin{array}{l}\text { DMSS0602 - Loading } \\
\text { Dock Container Shipping }\end{array}$} & Update SWITS Button & $\begin{array}{l}\text { The SDD does not have a } \\
\text { button to update SWITS. } \\
\text { However a button is } \\
\text { implemented to update SWITS }\end{array}$ & & $\begin{array}{l}\text { 05/01/96: Test Proc Review } \\
\text { Meet: appears on new screen } \\
\text { prints in Appendix A of } \\
\text { revised SDD } \\
\text { Discrepancy Item Closed }\end{array}$ \\
\hline & Refresh Location Button & $\begin{array}{l}\text { The SDD does not have a } \\
\text { button to refresh container } \\
\text { location. However, a button is } \\
\text { implemented to refresh } \\
\text { container location. }\end{array}$ & & $\begin{array}{l}\text { 05/01/96: Test Proc Review } \\
\text { Meet: appears on new screen } \\
\text { prints in Appendix A of } \\
\text { revised SDD } \\
\text { Discrepancy Item Closed }\end{array}$ \\
\hline
\end{tabular}




\begin{tabular}{|c|c|c|c|c|}
\hline SCREEN & CODE/SCREEN FEATURE & DISCREPANCY & $\begin{array}{l}\text { RATIONALE FOR } \\
\text { CATEGORY }\end{array}$ & RESOLUTION \\
\hline & $\begin{array}{l}\text { Function e_602_edit_swits() } \\
\text { Function i_602_swits_appmsds() } \\
\text { Function i_602_swits_chemcomp() } \\
\text { Function i_602_swits_conrel() } \\
\text { Function i_602_swits_hazdetail() } \\
\text { Function i_602_swits_isoqty0 } \\
\text { Function i_602_swits_physcomp() } \\
\text { Function i_602_swits_pkgdw() } \\
\text { Function i_602_swits_raddetailo } \\
\text { Function i_602_swits_shiphist() }\end{array}$ & $\begin{array}{l}\text { No source code is available for } \\
\text { these functions. }\end{array}$ & $\begin{array}{l}\text { Not sure if features have } \\
\text { been designed and/or } \\
\text { implemented correctly }\end{array}$ & $\begin{array}{l}\text { 05/01/96: Test Proc Review } \\
\text { Meet: upper data base } \\
\text { functions contained in data } \\
\text { base } \\
\text { Discrepancy Item Closed }\end{array}$ \\
\hline
\end{tabular}




\begin{tabular}{|c|c|c|c|c|}
\hline SCREEN & CODE/SCREEN FEATURE & DISCREPANCY & $\begin{array}{l}\text { RATIONALE FOR } \\
\text { CATEGORY }\end{array}$ & RESOLUTION \\
\hline & $\begin{array}{l}\text { Function i_602_swits_shipitem }() \\
\text { Function i_602_swits_shipment() } \\
\text { Function i_602_swits_verification() } \\
\text { Function u_602_swits_waste() } \\
\text { Function u_602_swits_rpkgstatus() }\end{array}$ & & & $\begin{array}{l}\text { Screen code validated during } \\
\text { testing. Revised } \\
\text { specification to be published } \\
\text { as new baseline with "as- } \\
\text { built" SDD revision. } \\
\text { Discrepancy item closed }\end{array}$ \\
\hline \multirow[t]{2}{*}{$\begin{array}{l}\text { DMSS0901 - Process } \\
\text { List Additions }\end{array}$} & Insert Button & \multirow[t]{2}{*}{$\begin{array}{l}\text { The SDD does not specify an } \\
\text { action for the Insert Button. }\end{array}$} & \multirow[t]{2}{*}{$\begin{array}{l}\text { Not sure if feature has } \\
\text { been designed and/or } \\
\text { implemented correctly }\end{array}$} & \multirow{2}{*}{$\begin{array}{l}\text { 2/20/96: Test Proc Review } \\
\text { Meet: SDD does not show a } \\
\text { "process" if they are selected } \\
\text { - update SDD or decide OK } \\
\text { as stands } \\
\text { Follow-on Test Results:. } \\
\text { These are standard buttons } \\
\text { for inserting or deleting a } \\
\text { row of data. OK as is. } \\
\text { Discrepancy item closed }\end{array}$} \\
\hline & Delete Button & & & \\
\hline
\end{tabular}




\begin{tabular}{|c|c|c|c|c|}
\hline SCREEN & CODE/SCREEN FEATURE & DISCREPANCY & $\begin{array}{l}\text { RATIONALE FOR } \\
\text { CATEGORY }\end{array}$ & RESOLUTION \\
\hline & Add to Process List & $\begin{array}{l}\text { Cannot determine if the proper } \\
\text { error message is being } \\
\text { displayed for duplicate pin } \\
\text { number. }\end{array}$ & & $\begin{array}{l}\text { 2/20/96: Test Proc Review } \\
\text { Meet: error codes should be } \\
\text { reviewed to determine if they } \\
\text { are operating correctly - } \\
\text { BCSR E-MAIL of } 2 / 22 / 96: \\
\text { Action Completed and } \\
\text { Discrepancy Item Closed }\end{array}$ \\
\hline \multirow[t]{2}{*}{$\begin{array}{l}\text { DMSS0902 - Process } \\
\text { List Additions }\end{array}$} & \multirow[t]{2}{*}{ Move Button } & $\begin{array}{l}\text { Although this agrees with the } \\
\text { SDD there is no way to move } \\
\text { a package id from the 'process } \\
\text { list' to the 'not process list'. } \\
\text { The code for that feature is } \\
\text { commented out. }\end{array}$ & $\begin{array}{l}\text { Feature may not be } \\
\text { implemented }\end{array}$ & $\begin{array}{l}\text { 3/25/96: Test Proc Review } \\
\text { Meet: OK - defunct code - } \\
\text { rereads data base instead of } \\
\text { "moving" anything - needs to } \\
\text { be cleaned out. SDD is OK } \\
\text { Code should be cleaned up }\end{array}$ \\
\hline & & $\begin{array}{l}\text { The code assumes it is on } \\
\text { cursor block 'notproclist' by } \\
\text { testing if it is not on cursor } \\
\text { 'proclist'. } \\
\text { Does the form have to be on } \\
\text { one of the cursors? }\end{array}$ & Needs to be verified & $\begin{array}{l}\text { 3/25/96: Test Proc Review } \\
\text { Meet: doesn't affect screen } \\
\text { performance - considered a } \\
\text { "programmers call" on logic } \\
\text { - need to check to see what } \\
\text { testing shows for results } \\
\text { Follow-on Test Results: Test } \\
\text { DMS-F21 has successfully } \\
\text { passed. } \\
\text { Discrepancy item Closed }\end{array}$ \\
\hline
\end{tabular}




\begin{tabular}{|c|c|c|c|c|}
\hline SCREEN & CODE/SCREEN FEATURE & DISCREPANCY & $\begin{array}{l}\text { RATIONALE FOR } \\
\text { CATEGORY }\end{array}$ & RESOLUTYON \\
\hline $\begin{array}{l}\text { DMSS0903 - AS/RS } \\
\text { Storage Pick List }\end{array}$ & Drum direction indicator & $\begin{array}{l}\text { The SDD states... } \\
\text { Provide arrow or other } \\
\text { indicator to show direction of } \\
\text { drum movement is from the } \\
\text { bottom to top of list. } \\
\text { No indicator is present. }\end{array}$ & \multirow[t]{5}{*}{$\begin{array}{l}\text { Not sure if feature has } \\
\text { been designed and/or } \\
\text { implemented correctly }\end{array}$} & $\begin{array}{l}\text { 3/25/96: Test Proc Review } \\
\text { Meet: arrow hard coded - } \\
\text { latest revision to SDD now } \\
\text { shows arrow in screen print } \\
\text { Discrepancy Item Closed }\end{array}$ \\
\hline \multirow[t]{4}{*}{. } & Data field RDET_PDR_NUM & $\begin{array}{l}\text { The SDD data dictionary has } \\
\text { RDET PDR NUM in the } \\
\text { RADDETAIL table. The } \\
\text { source code does not. }\end{array}$ & & \multirow[t]{4}{*}{$\begin{array}{l}\text { Update to SDD: latest } \\
\text { revision of SDD shows new } \\
\text { data elements added to data } \\
\text { dictionary } \\
\text { Discrepancy Item Closed }\end{array}$} \\
\hline & $\begin{array}{l}\text { Data field } \\
\text { HDET_IND_DOT_ID_NUM }\end{array}$ & $\begin{array}{l}\text { The SDD data dictionary has } \\
\text { HDET_DOT_ID_NUM in the } \\
\text { HAZDETAIL_table. The } \\
\text { source code does not. }\end{array}$ & & \\
\hline & $\begin{array}{l}\text { Data field } \\
\text { HDET_IND_NOS_DESCR }\end{array}$ & $\begin{array}{l}\text { The SDD data dictionary has } \\
\text { HDET_IND_NOS_DESCR in } \\
\text { the HAZDETAIL table. The } \\
\text { source code does not. }\end{array}$ & & \\
\hline & $\begin{array}{l}\text { Data field } \\
\text { HDET_IND_SHIP_NAME }\end{array}$ & $\begin{array}{l}\text { The SDD data dictionary has } \\
\text { HDET_IND_SHIP_NAME in } \\
\text { the HAZDETAIL table. The } \\
\text { source code does not. }\end{array}$ & & \\
\hline
\end{tabular}


WRAP 1 DMS VALIDATION AND

VERIFICATION REPORT

-HNF-1783

Revision 0

September 27, 1996

\begin{tabular}{|c|c|c|c|c|}
\hline SCREEN & CODE/SCREEN FEATURE & DISCREPANCY & $\begin{array}{l}\text { RATIONALE FOR } \\
\text { CATEGORY }\end{array}$ & RESOLUTION \\
\hline $\begin{array}{l}\text { DMSS0904 - AS/RS } \\
\text { Shipping Pick List }\end{array}$ & LLW Button/TRU Button & $\begin{array}{l}\text { The SDD has "Select BIN, } \\
\text { RADDETAIL, CONLOC, } \\
\text { WASTEXT where all } \\
\text { BIN_PKG_ID_\#= } \\
\text { RDET_PKG_ID and } \\
\text { RDET_SWTYP_GROUP = } \\
\text { 'SWTYP'" } \\
\text { proper values for } \\
\text { RDET_SWTYP_GROUP are } \\
\text { LIW for the LLW Button and } \\
\text { TRU for the TRU Button }\end{array}$ & $\begin{array}{l}\text { SDD specifies an } \\
\text { inappropriate comparison }\end{array}$ & $\begin{array}{l}\text { 05/01/96: Test Proc Review } \\
\text { Meet: screen acts in testing } \\
\text { as intended - sets button for } \\
\text { the SWTYP_GROUP as } \\
\text { required } \\
\text { Discrepancy Item Closed }\end{array}$ \\
\hline
\end{tabular}




\begin{tabular}{|c|c|c|c|c|}
\hline SCREEN & CODE/SCREEN FEATURE & DISCREPANCY & $\begin{array}{l}\text { RATIONALE FOR } \\
\text { CATEGORY }\end{array}$ & RESOLUTION \\
\hline \multicolumn{5}{|c|}{ CATEGORY 3 DISCREPANCIES } \\
\hline \multirow[t]{2}{*}{$\begin{array}{l}\text { DMSS0101 - Commit } \\
\text { Button }\end{array}$} & send_cl_to_pes & This feature is not in the SDD. & $\begin{array}{l}\text { Not sure if feature has } \\
\text { been designed and/or } \\
\text { implemented correctly }\end{array}$ & $\begin{array}{l}\text { Resolution provided after } \\
\text { V\&V Review: Screen has } \\
\text { been successfully tested and } \\
\text { accepted. } \\
\text { Discrepancy Item Closed }\end{array}$ \\
\hline & Buttons in General & $\begin{array}{l}\text { The SDD does not specify } \\
\text { when a particular button shall } \\
\text { be active or inactive. }\end{array}$ & $\begin{array}{l}\text { Although a feature is } \\
\text { implemented it can not be } \\
\text { determined if it is } \\
\text { available at the time it is } \\
\text { needed }\end{array}$ & $\begin{array}{l}\text { Resolution provided after } \\
\text { V\&V Review: True. } \\
\text { Buttons are not consistently } \\
\text { specified as active or } \\
\text { inactive. Screens are being } \\
\text { tested and accepted as is } \\
\text { without this consistency. } \\
\text { Discrepancy Item Closed }\end{array}$ \\
\hline $\begin{array}{l}\text { DMSS0201 - Drum or } \\
\text { Box NDE Certification } \\
\text { Data }\end{array}$ & Save Button & $\begin{array}{l}\text { The SDD lists a SAVE Button } \\
\text { the screen print has a } \\
\text { COMMIT Button. }\end{array}$ & $\begin{array}{l}\text { Should update Appendix } \\
\text { F to be consistent }\end{array}$ & $\begin{array}{l}\text { 2/20/96: Test Proc Review } \\
\text { Meet: need to change SDD }\end{array}$ \\
\hline
\end{tabular}




\begin{tabular}{|c|c|c|c|c|}
\hline SCREEN & CODE/SCREEN FEATURE & DISCREPANCY & $\begin{array}{l}\text { RATIONALE FOR } \\
\text { CATEGORY }\end{array}$ & RESOLUTION \\
\hline $\begin{array}{l}\text { DMSSO312 - Sample } \\
\text { Button }\end{array}$ & sample_btn & $\begin{array}{l}\text { The SDD -- Go to DMSSOS01 } \\
\text { (DMSS0212 screen data should } \\
\text { not have to be committed } \\
\text { before going to DMSSO312 } \\
\text { screen) } \\
\text { This is vague. Is this in error } \\
\text { and should read (DMSS0212 } \\
\text { screen data should not have to } \\
\text { be committed before going to } \\
\text { DMSS0501 screen) } \\
\text { or (DMSS0212 screen data } \\
\text { should not have to be } \\
\text { committed before coming back } \\
\text { to DMSS0312 screen) } \\
\text { or both. }\end{array}$ & \multirow[t]{2}{*}{$\begin{array}{l}\text { Not sure if feature has } \\
\text { been designed and/or } \\
\text { implemented correctly }\end{array}$} & $\begin{array}{l}\text { Screen code validated during } \\
\text { testing. Revised } \\
\text { specification to be published } \\
\text { as new baseline with "as- } \\
\text { built" SDD revision. } \\
\text { Discrepancy item closed }\end{array}$ \\
\hline $\begin{array}{l}\text { DMSS0901 - Process } \\
\text { List Additions }\end{array}$ & Request screen from Pick List menu & $\begin{array}{l}\text { The SDD does not define a } \\
\text { screen field for column } 1 \\
\text { "Seq" }\end{array}$ & & $\begin{array}{l}\text { Follow-on Test Results: } \\
\text { Screen works properly as } \\
\text { tested in DMS-F21. SDD } \\
\text { should specify this field. } \\
\text { Resolution provided after } \\
\text { V\&V Review: SDD does } \\
\text { specify this field. } \\
\text { Discrepancy Item Closed }\end{array}$ \\
\hline
\end{tabular}




\begin{tabular}{|c|c|c|c|c|}
\hline SCREEN & CODE/SCREEN FEATURE & DISCREPANCY & $\begin{array}{l}\text { RATIONALE FOR } \\
\text { CATEGORY }\end{array}$ & RESOLUTION \\
\hline & up button & This feature is not in the SDD. & & $\begin{array}{l}\text { Follow-on Test Results: } \\
\text { This is a standard button and } \\
\text { is not generally described in } \\
\text { the SDD for any of the } \\
\text { screens. } \\
\text { Discrepancy Item Closed }\end{array}$ \\
\hline & down button & & & $\begin{array}{l}\text { Follow-on Test Results: } \\
\text { This is a standard button and } \\
\text { is not generally described in } \\
\text { the SDD for any of the } \\
\text { screens. } \\
\text { Discrepancy Item Closed. }\end{array}$ \\
\hline & scroll-up button & & & $\begin{array}{l}\text { Follow-on Test Results: } \\
\text { This is a standard button and } \\
\text { is not generally described in } \\
\text { the SDD for any of the } \\
\text { screens. } \\
\text { Discrepancy Item Closed }\end{array}$ \\
\hline & scroll-down button & & & $\begin{array}{l}\text { Follow-on Test Results: } \\
\text { This is a standard button and } \\
\text { is not generally described in } \\
\text { the SDD for any of the } \\
\text { screens. } \\
\text { Discrepancy Item Closed }\end{array}$ \\
\hline
\end{tabular}




\begin{tabular}{|c|c|c|c|c|}
\hline SCREEN & CODE/SCREEN FEATURE & DISCREPANCY & $\begin{array}{l}\text { RATIONALE FOR } \\
\text { CATEGORY }\end{array}$ & RESOLUTION \\
\hline \multirow[t]{6}{*}{$\begin{array}{l}\text { DMSSO902 - Process } \\
\text { List Additions }\end{array}$} & Request screen from Pick List menu & $\begin{array}{l}\text { The SDD has the column title } \\
\text { for column } 1 \text { "PCS Flag" it is } \\
\text { implemented as "PICK LIST" }\end{array}$ & & $\begin{array}{l}\text { Follow-on Test Results: } \\
\text { Feature implemented. } \\
\text { properly but should be PICK } \\
\text { LIST in the SDD. }\end{array}$ \\
\hline & up button & This feature is not in the SDD. & & \multirow{4}{*}{$\begin{array}{l}\text { Follow-on Test Results: } \\
\text { This is a standard button and } \\
\text { is not generally described in } \\
\text { the SDD for any of the } \\
\text { screens. } \\
\text { Discrepancy Item Closed }\end{array}$} \\
\hline & down button & & & \\
\hline & scroll-up button & & & \\
\hline & scroll-down button & & & \\
\hline & send_to_pcs & $\begin{array}{l}\text { The SDD has "Send all } \\
\text { PROC_PCS_FLAG = null" } \\
\text { The code has } \\
\text { "proc_pcs_flag='Y'" }\end{array}$ & & $\begin{array}{l}\text { Follow-on Test Results: } \\
\text { Screen works properly as } \\
\text { tested in DMS-F21. } \\
\text { Discrepancy Item Closed }\end{array}$ \\
\hline
\end{tabular}


WRAP 1 DMS VALIDATION AND

VERIFICATION REPORT
HNF-1783

Revision 0

September 27, 1996

\begin{tabular}{|c|c|c|c|c|}
\hline SCREEN & CODE/SCREEN FEATURE & DISCREPANCY & $\begin{array}{c}\text { RATIONALE FOR } \\
\text { CATEGORY }\end{array}$ & RESOLUTION \\
\hline & send_to_pes & $\begin{array}{l}\text { The SDD does not specify a } \\
\text { maximum number of drums for } \\
\text { the pick list screen to handle. } \\
\text { The variable which holds the } \\
\text { message text to be sent is } 2000 \\
\text { characters. This allows for } \\
\text { about } 82 \text { drums. This seams } \\
\text { like plenty, but a maximum } \\
\text { should be specified. }\end{array}$ & & $\begin{array}{l}\text { Screen code validated during } \\
\text { testing. Revised } \\
\text { specification to be published } \\
\text { as new baseline with "as- } \\
\text { built" SDD revision. } \\
\text { Discrepancy item closed }\end{array}$ \\
\hline
\end{tabular}




\subsection{BWAS SIMULATOR SOURCE CODE REVIEW}

\subsubsection{Purpose}

This analysis compares the source code for the BWAS Simulator with the DMS design specifications to determine if the simulator will accurately pass and receive data and messages to and from the DMS modules.

\subsubsection{Scope}

This analysis focused on the ORACLE source code and the DMS modules that process boxed waste and interact with the assay conducted by the BWAS.

While reviewing the BWAS Simulator; some considerations affecting the System Integration Equipment (SIE) Simulator were noted and included in this analysis.

\subsubsection{Analysis Approach}

For this analysis, one matrix was prepared comparing the source code and the functional intent of the BWAS Simulator. This analysis compares the source code for the BWAS Simulator with the DMS design specifications to determine if the simulator will accurately pass and receive data and messages to and from the DMS modules.

\subsubsection{Analytic Overview}

\subsubsection{General Observations}

The BWAS Simulator is based on the SIE Simulator. The BWAS Simulator is not simply designed after the SIE Simulator: it is, in fact, almost identical. The SIE Simulator has been modified only for different TCP/IP addresses, port addresses, DMS messages, and some cosmetic changes of some of the variable names. The only messages not processed by the BWAS Simulator that the SIE Simulator processes are dmsrsie_sdpO and dmsrsie_sdg0, which send the drum database to the PAN and GEA. These two functions are not needed for handling boxed waste. The BWAS Simulator should function as designed, which is to send messages to DMS and log messages received. 


\subsubsection{Discrepancy Synopsis and Resolution Matrix}

The following matrix contains a synopsis of the discrepancies that are described in more detail in the analytic matrices found in the DMS project files. This synopsis groups the discrepancies by category. It then provides resolution actions that were decided during the course of the V\&V analysis. As of the date of this report, the DMS development that will use the BWAS Simulator has not started. Consequently, the information reported has not yet been acted upon.

The resolution matrix will be considered a tracking mechanism to monitor all discrepancies until they are closed. Consequently, it will be periodically updated to reflect closed actions. If requirements are changed during the DMS development, these changes will be noted in the resolution matrix as pending actions and tracked as with any other actions. 


\begin{tabular}{|c|c|c|c|}
\hline $\begin{array}{l}\text { PROCEDURE } \\
\text { NAME }\end{array}$ & DISCREPANCY & $\begin{array}{l}\text { RATIONALE FOR } \\
\text { CATEGORY }\end{array}$ & RESOLUTION \\
\hline \multicolumn{4}{|c|}{ CATEGORY 2 DISCREPANCIES } \\
\hline dmssbwa_bdo & $\begin{array}{l}\text { The log message function logs ch_number_radionuclides } \\
\text { twice. The equivalent message dmssie_dd() logs } \\
\text { ch_number_radionuclides only once }\end{array}$ & $\begin{array}{l}\text { Does not seem to be a need for } \\
\text { this value to be sent twice }\end{array}$ & Should be sent once \\
\hline \multicolumn{4}{|c|}{ CATEGORY 3 DISCREPANCIES } \\
\hline dmsrbwa_abwa0 & \multirow[t]{4}{*}{ No equivalent function for the SIE Simulator } & \multirow{4}{*}{$\begin{array}{l}\text { May be a need for an equivalent } \\
\text { message for SIE Simulator }\end{array}$} & \multirow{4}{*}{$\begin{array}{l}\text { Should consider } \\
\text { update of SDD }\end{array}$} \\
\hline bwadms_bas() & & & \\
\hline bwadms_baaO & & & \\
\hline bwadms_baco & & & \\
\hline
\end{tabular}




\subsubsection{Discrepancy Synopsis and Resolution Matrix}

The following matrix contains a synopsis of the discrepancies that are described in more detail in the analytic matrices found in the DMS project files. This synopsis groups the discrepancies by category. It then provides resolution actions that were decided during the course of the V\&V analysis. As of the date of this report, the DMS development that will use the BWAS Simulator has not started. Consequently, the information reported has not yet been acted upon.

The resolution matrix will be considered a tracking mechanism to monitor all discrepancies until they are closed. Consequently, it will be periodically updated to reflect closed actions. If requirements are changed during the DMS development, these changes will be noted in the resolution matrix as pending actions and tracked as with any other actions. 


\begin{tabular}{|c|c|c|c|}
\hline $\begin{array}{l}\text { PROCEDURE } \\
\text { NAME }\end{array}$ & DISCREPANCY & $\begin{array}{l}\text { RATIONALE FOR } \\
\text { CATEGORY }\end{array}$ & RESOLUTION \\
\hline \multicolumn{4}{|c|}{ CATEGORY 2 DISCREPANCIES } \\
\hline dmssbwa_bd() & $\begin{array}{l}\text { The log message function logs ch_number_radionuclides } \\
\text { twice. The equivalent message dmssie_dd } 0 \text { logs } \\
\text { ch_number_radionuclides only once. }\end{array}$ & $\begin{array}{l}\text { Does not seem to be a need for } \\
\text { this value to be sent twice }\end{array}$ & Should be sent once \\
\hline \multicolumn{4}{|c|}{ CATEGORY 3 DISCREPANCIES } \\
\hline dmsrbwa_abwa() & \multirow[t]{4}{*}{ No equivalent function for the SIE Simulator } & \multirow{4}{*}{$\begin{array}{l}\text { May be a need for an equivalent } \\
\text { message for SIE Simulator }\end{array}$} & \multirow{4}{*}{$\begin{array}{l}\text { Should consider } \\
\text { update of SDD }\end{array}$} \\
\hline bwadms_bas 0 & & & \\
\hline bwadms_baa() & & & \\
\hline bwadms_bac() & & & \\
\hline
\end{tabular}




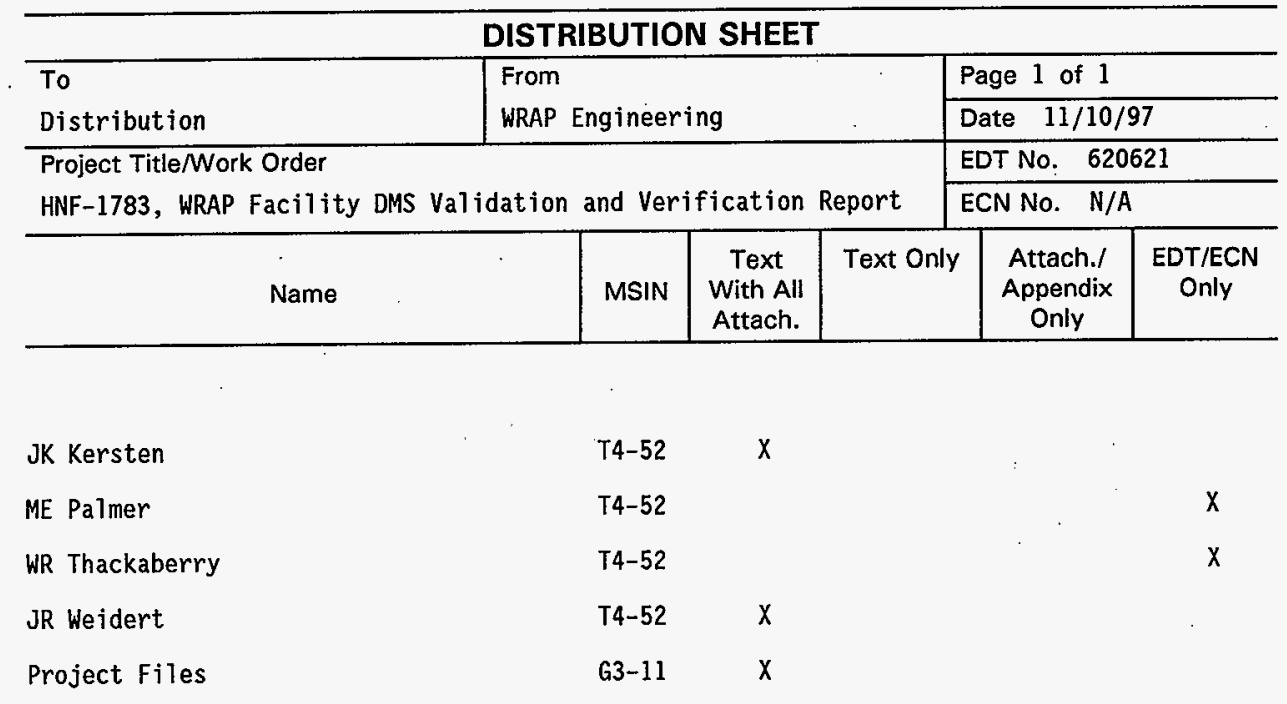

